\title{
EVALUATION OF THE WIND SYSTEM ATMOSPHERIC MODELS: AN ANALYTIC APPROACH (U)
}

\author{
J. D. FAST
}

Publication Date: November 25, 1991

Westinghouse Savannah River Company Savannah River Site Aiken, SC 29808

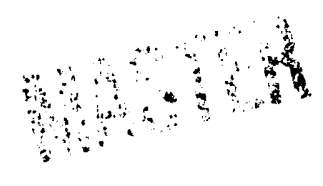




\section{CONTENTS}

ABSTRACT

1.0 INTRODUCTION

2.0 WIND SYSTEM ATMOSPHERIC MODEIS

2.1 AREA EVACUATION Code, Version 2.0

2.2 PUFF/PLUME Code, Version $2.5 \quad 3$

2.3 2DPUF Code, Version $3.1 \quad 3$

3.0 DESCRIPTION OF THE ATMOSPHERIC MODELS 3

3.1 Representation of the Physical Processes 4

3.1.1 AREA EVACUATION 4

3.1.2 PUFF/PLUME

$\begin{array}{ll}3.1 .32 D P U F & 7\end{array}$

3.2 Meteorological Input 7

3.2.1 AREA EVACUATION 8

3.2.2 PUFF/PLUME $\quad 8$

$\begin{array}{ll}3.2 .32 D P U F & 9\end{array}$

$\begin{array}{lll}3.3 & \text { Source Input } & 10\end{array}$

3.3.1 AREA EVACUATION 10

3.3.2 PUFF/PLUME 11

$\begin{array}{ll}3.3 .32 D P U F & 12\end{array}$

3.4 Numerical Procedure $\quad 12$

3.4.1 AREA EVACUATION 12

3.4.2 PUFF/PLUME 13

$\begin{array}{ll}3.4 .32 \text { DPUF } & 13\end{array}$

3.5 Appropriateness of the Model Assumptions 14

3.5.1 AREA EVACUATION 14 
CONTENTS (cont'd)

3.5.2 PUFF/PLUME 15

3.5.3 2DPUF 16

3.5.4 Comparison with other models 17

$\begin{array}{lll}4.0 & \text { COMPARISON AGAINST ANALYTIC SOLUTIONS } & 17\end{array}$

4.1 AREA EVACUATION 18

$\begin{array}{lll}4.2 & \text { PUFF/PLUME } & 19\end{array}$

4.3 2DPUF 21

5.0 CONCLUSION 23

REFERENCES 


\section{LIST OF FIGURES}

Figure 1. Horizontal standard deviation of the plume width, $\sigma_{y}$, calculated by AREA EVACUATION for various stability classes (cases 1, 7, 8, 9, 10, 11 from Table 1)

Figure 2. Same as Fig. 1, except for vertical standard deviation of the plume width, $\sigma_{z}$

Figure 3. Dose rate or concentration calculated by AREA

EVACUATION for various radionuclides and chemicals (cases 1, 2, 3, 4 from Table 1)

Figure 4. Dose rate calculated by AREA EVACUATION for various mixing depths (cases $1,5,6,7$ from Table 1)

Figure 5. Dose rate calculated by AREA EVACUATION for various wind speeds (cases $1,12,13,14,15$ from Table 1)

Figure 6. Dose rate calculated by AREA EVACUATION for various stability classes (cases $1,7,8,9,10,11$ from Table 1)

Figure 7. (a) Horizontal standard deviation of the plume width, $\sigma_{y}$, calculated by the analytic solution and (b) percent error of the numerical solution calculated by PUFF/PLUME for various stability classes assuming a continuous release (cases $1,7,8,9,10,11$ from Table 1)

Figure 8. Same as Fig. 7a, except for vertical standard deviation of the plume width, $\sigma_{z}$

Figure 9. (a) Dose or concentration calculated by the analytic solution and (b) percent error of the numerical solution calculated by PUFF/PLUME for various radionuclides and chemicals assuming a continuous release (cases $1,2,3,4$ from Table 1)

Figure 10. (a) Dose calculated by the analytic solution and (b) percent error of the numerical solution calculated by PUFF/PLUME for various mixing depths assuming a continuous release (cases 1, 5, 6, 7 from Table 1)

Figure 11. (a) Dose calculated by the analytic solution and (b) percent error of the numerical solution calculated by PUFF/PLUME for various wind speeds assuming a continuous release (cases 1, 12, 13, 14, 15 from Table 1)

Figure 12. (a) Dose calculated by the analytic solution and (b) percent error of the numerical solution calculated by PUFF/PLUME for various stability classes assuming a continuous release (cases 1, 7, 8, 9, 10, 11 from Table 1) 
Figure 13. (a) Horizontal standard deviation of the plume width, $\sigma_{y}$, calculated by the analytic solution and (b) percent error of the numerical solution calculated by PUFF/PLUME for various stability classes assuming an instantaneous release (cases $1,7,8,9,10,11$ from Table 1)

Figure 14. Same as Fig. 13, except for vertical standard deviation of the plume width, $\sigma_{z}$

Figure 15. (a) Dose or concentration calculated by the analytic solution and (b) percent error of the numerical solution calculated by PUFF/PLUME for various radionuclides and chemicals assuming an instantaneous release (cases $1,2,3,4$ from Table 1)

Figure 16. (a) Dose calculated by the analytic solution and (b) percent error of the numerical solution calculated by PUFF/PLUME for various mixing depths assuming an instantaneous release (cases $1,5,6,7$ from Table 1)

Figure 17. (a) Dose calculated by the analytic solution and (b) percent error of the numerical solution calculated by PUFF/PLUME for various wind speeds assuming an instantaneous release (cases $1,12,13,14,15$ from Table 1)

Figure 18. (a) Dose calculated by the analytic solution and (b) percent error of the numerical solution calculated by PUFF/PLUME for various stability classes assuming an instantaneous release (cases $1,7,8,9,10,11$ from Table 1 )

Figure 19. Horizontal standard deviation of the plume width, $\sigma_{y}$, calculated by the analytic solution and 2DPUF for various stability classes assuming an instantaneous release (cases $1,7,8,9,10,11$ from Table 1 )

Figure 20. Same as Fig. 19, except for vertical standard deviation of the plume width, $\sigma_{z}$

Figure 21. (a) Dose calculated by the analytic solution and (b) percent error of the numerical solution calculated by $2 \mathrm{DPI}$ ( for various radionuclides assuming an instantaneous release (cases 1, 3, 4 from Table 1)

Figure 22. (a) Dose calculated by the analytic solution and (b) percent error of the numerical solution calculated by 2DPUF for various mixing depths assuming an instantaneous release (cases $1,5,6,7$ from Table 1 ) 
Figure 23. (a) Dose calculated by the analytic solution and (b) percent error of the numerical solution calculated by 2DPUF for various wind speeds assuming an instantaneous release (cases 1, 7, 8, 9, 10, 11 from Table 1)

Figure 24. (a) Dose calculated by the analytic solution and (b) percent error of the numerical solution calculated by $2 D P U F$ for various stability classes assuming an instantaneous release (cases 1, 7, 8, 9, 10, 11 from Table 1)

Figure 25. Percent error of the numerical solution calculated by 2DPUF where "A - test" indicates results from a simulation where the time step was reduced by a factor of three and "F - test" indicates results from a simulation where the initial time step was changed from $20 \mathrm{~s}$ to $10 \mathrm{~s}$ (cases 7,11 from Table 1)

Figure 26. (a) Dose calculated by the analytic solution and (b) percent error of the numerical solution calculated by 2DPUF for one puff and two puffs (case 1 from Table 1)

Figure 27. Percent of the doses computed by PUFF/PLUME and 2DPUF within a factor of $R$ of the analytic solution for the cases in Tables 1 and 2 
Table 1. Meteorological input parameters for AREA EVACUATION, PUFF/PLUME, 2DPUF, and the corresponding analytic solutions

Table 2. Source term input parameters for AREA EVACUATION, PUFF/PLUME, 2DPUF, and the corresponding analytic solutions where the release duration is $60 \mathrm{~min}$ for continuous releases (plume) and $15 \mathrm{~min}$ for instantaneous releases (puff)

Table 3. Comparison of the analytic solution (AS), Eq. (2), and the numerical results (NS) calculated by AREA EVACUATION using the input parameters given for caise 1 (default case) listed in Tables 1 and 2

Table 4. Same as Table 3, but for case 2 and analytic solution given by Eq. (1)

Table 5. Same as Table 3 , but for case 3

Table 6. Same as Table 3, but for case 4

Table 7. Same as Table 3, but for case 5

Table 8. Same as Table 3, but for case 6

Table 9. Same as Table 3, but for case 7

Table 10. Same as Table 3 , but for case 8

Table 11. Same as Table 3, but for case 9

Table 12. Same as Table 3 , but for case 10

Table 13. Same as Table 3, but for case 11 
Table 15. Same as Table 3, but for case $13 \quad 56$

Table 16. Same as Table 3, but for case 14

Table 17. Same as Table 3, but for case 15

Table 18. Comparison of the analytic solution (AS), Eq. (6), and the numerical results (NS) calculated by PUFF/PLUME for plume using the input parameters given for case 1 (default case) listed in Tables 1 and 2

Table 19. Same as Table 18, but for case 2 and analytic solution given by Eq. (5)

Table 20. Same as Table 18, but for case $3 \quad 59$

Tatie 21. Same as Table 18, but for case $4 \quad 59$

Table 22. Same as Table 18, but for case $5 \quad 60$

Table 23. Same as Table 18, but for case $6 \quad 60$

Table 24. Same as Table 18, but for case $7 \quad 61$

Table 25. Same as Table 18, but for case $8 \quad 61$

Table 26. Same as Table 18, but for case $9 \quad 62$

Table 27. Same as Table 18, but for case $10 \quad 62$

Table 28. Same as Table 18, but for case 11

Table 29. Same as Table 18, but for case $12 \quad 63$

Table 30. Same as Table 18, but for case $13 \quad 65$

Table 31. Same as Table 18, but for case $14 \quad 65$

Table 32. Same as Table 18, but for case $15 \quad 66$

Table 33. Comparison of the analytic solution (AS), Eq. (9), and the numerical results (NS) calculated by PUFF/PLUME for puff using the input parameters given for case 1 (default case) listed in Tables 1 and 2

Table 34. Same as Table 33, but for case 2 and analytic solution given by Eq. (7)

Table 35. Same as Table 33, but for case $3 \quad 68$ 
Table 36. Same as Table 33, but for case 4

Table 37. Same as Table 33, but for case 5

Table 38. Same as Table 33, but for case 6

$\begin{array}{lll}\text { Table 39. Same as Table 33, but for case } 7 & \mathbf{7 0}\end{array}$

Table 40. Same as Table 33, but for case $8 \quad 70$

Table 41. Same as Table 33, but for case $9 \quad 71$

$\begin{array}{lll}\text { Table 42. Same as Table 33, but for case } 10 & 71\end{array}$

Table 43. Same as Table 33, but for case 11 72

Table 44. Same as Table 33, but for case 12

Table 45. Same as Table 33, but for case $13 \quad 74$

Table 46. Same as Table 33, but for case 14

Table 47. Same as Table 33, but for case $15 \quad 75$

Table 48. Comparison of the analytic solution (AS), Eq. (13), and the numerical results (NS) calculated by $2 \mathrm{DPUF}$ using the input parameters given for case 1 (default case) listed in Tables 1 and 2

Table 49. Same as Table 48, but for case $3 \quad 76$

$\begin{array}{lll}\text { Table 50. Same as Table 48, but for case } 4 & 77\end{array}$

$\begin{array}{lll}\text { Table 51. } & \text { Same as Table 48, but for case } 5 & 77\end{array}$

$\begin{array}{lll}\text { Table 52. Same as Table 48, but for case } 6 & 78\end{array}$

$\begin{array}{lll}\text { Table 53. Same as Table 48, but for case } 7 & 78\end{array}$

$\begin{array}{lll}\text { Table 54. Same as Table 48, but for case } 8 & 79\end{array}$

Table 55. Same as Table 48, but for case $9 \quad 79$

$\begin{array}{lll}\text { Table 56. Same as Table 48, but for case } 10 & 80\end{array}$

$\begin{array}{lll}\text { Table 5\%. Same as Table 48, but for case } 11 & 80\end{array}$

$\begin{array}{lll}\text { Table 58. Same as Table 48, but for case } 12 & 81\end{array}$ 


\section{LIST OF TABLES (cont'd)}

$\begin{array}{llr}\text { Table 59. } & \text { Same as Table } 48 \text {, but for case } 13 & 81\end{array}$

Table $60 . \quad$ Same as Table 48, but for case $14 \quad 82$

Table 61. Same as Table 48, but for case 15 


\title{
EVALUATION OF THE WIND SYSTEM ATMOSPHERIC MODELS: AN ANALYTIC APPROACH
}

\author{
By J. D. Fast \\ Westinghouse Savannah River Company \\ Savannah River Site \\ Aiken, SC 29808
}

\begin{abstract}
An analytic approach was used in this study to test the logic, coding, and the theoretical limits of the WIND System atmospheric models. In this method, dose or concentration estimates predicted by the models were compared to the analytic solutions to evaluate their performance. The results from AREA EVACUATION and PUFF/PLUME were very nearly identical to the analytic solutions they are based on and the evaluation procedure demonstrated that these models were able to reproduce the theoretical characteristics of a puff or a plume. The dose or concentration predicted by PUFF/PLUME was always within $1 \%$ of the analytic solution. Differences between the dose predicted by 2DPUF and its analytic solution were substantially greater than those associated with PUFF/PLUME, but were usually smaller than $6 \%$. This behavior was expected because PUFF/PLUME solves a form of the analytic solution for a single puff, and 2DPUF performs an integration over a period of time for several puffs to obtain the dose. Relatively large differences between the dose predicted by 2DPUF and its analytic solution were found to occur close to the source under stable atmospheric conditions. WIND System users should be aware of these situations in which the assumptions of the WIND System atmospheric models may be violated so that dose predictions can be interpreted correctly. The WIND System atmospheric models are similar to many other dispersion codes used by the EPA, NRC, and DOE. If the quality of the source term and meteorological data is high, relatively accurate and timely forecasts for emergency response situations can be made by the WIND System atmospheric models.
\end{abstract}

\subsection{INTRODUCTION}

Atmospheric transport and diffusion models have been developed for real-time calculations of the location and concentration of toxic or radioactive materials during an accidental release at the Savannah River Site (SRS). These models have been incorporated into an automated menu-driven system called the WIND (Weather INformation and Display) System and linked to real-time meteorological and radiological monitoring instruments to provide timely information for these emergency response activities 1 .

The WIND system atmospheric models have been shown to qualitatively predict the regions where toxic or radioactive material may be transported. This has been confirmed by comparing a number of tracer experiments performed at the site $^{2}$ to the results predicted by PUFF/PLUME and $2 \mathrm{DPUF}^{3}$; however, no formal evaluation of the numerical codes of the atmospheric models has been performed.

In an effort to establish more formal quality assurance procedures for the WIND system atmospheric codes, a software evaluation is being conducted by the ETS ${ }^{4}$. The software evaluation will determine how well these models may perform in emergency response (real- 
time) situations. This report is one component of the software evaluation which will describe an analytic method that is used to test the logic and assumptions employed by the atmospheric model software. During the evaluation, possible sources of error in the model results including input errors (due to meteorological and source input) and model errors (due to model assumptions and numerical procedures) will be identified. Other evaluation methods, including a comparison of the model results with observed data ${ }^{5}$ and an intermodel comparison study 6 , have also recently been completed.

The performance of the atmospheric models will be based on certain dispersion characteristics that are important in emergency response situations. Some of these characteristics include:

(1) Centerline location of plume or puff,

(2) Centerline dose or concentration (peak and average),

(3) Width of plume or puff (peak and average),

(4) Overall integrated dose or concentration in time at a particular location,

(5) Peak dose or concentration estimates (uncorrelated in space and time),

(6) Peak dose or concentration estimates (correlated spatially or temporally),

(7) Dose or concentration estimates (correlated spatially or temporally).

This study focuses on characteristics (1) - (3) which can be evaluated relatively easily by an analytic approach. Characteristics (4) - (7) art tramined in more detail in other components of the software evaluation ${ }^{5,6}$.

This report consists of three parts including:

(2) Description of the Atmospheric Models: A detailed description of the important equations and the assumptions employed in the individual models is presented.

(3) Comparison Against the Analytic Solutions: The atmospheric models and the analytic solutions were executed with the same source strength and meteorological data. The dose or concentration estimates, as well and other important dispersion characteristics, are compared and evaluated.

Evaluation in this study refers to the process of examining and appraising the performance by comparing the model's concentration or dose estimates to measurements or theoretical values. A formal definition of evaluation techniques for dispersion models can oe found in reference 7.

\subsection{WIND SYSTEM ATMOSPHERIC MODELS}

The components of the WIND system atmospheric models to be evaluated will include AREA EVACUATION, PUFF/PLUME and 2DPUF. These models vary in complexity depending on the specific purpose for which they were designed; therefore, different evaluation techniques will be required for each model. This section will briefly describe the specific objective of each atmospheric model.

The WIND system atmospheric models can be accessed by SRS users through the WIND System computer. The WIND System computer consists of two Digital Equipment Corporation (DEC) microcomputers: currently two VAX 8550's clustered to provide disk shadowing for redundancy. A complete list of the WIND system computer terminals can be found in the WIND System User's Manual' ${ }^{1}$. 


\subsection{AREA EVACUATION Code, Version 2.0}

The AREA EVACUATION code is designed to assess the consequences of accidental releases of hazardous materials from SRS production facilities within the limited area fence. This code executes very quickly because a simple, straight-line Gaussiari assumption has been employed. Observations from the SRS meteorological towers are used to calculate the plume direction, plume width, and dose estimates in the immediate vicinity of a release. The code uses the most recent wind data at a specific site and does not allow it to vary in space or in time.

\subsection{PUFF/PLUME Code, Version 2.5}

The PUFF/PLUME code ${ }^{1,8}$ is a sequential Gaussian model designed to predict plume characteristics and perform dosimetry calculations for the site boundary and beyond due to an accidental release from SRS production facilities. This program is used to support initial onsite and offsite emergency response activities such as protective action decision making and field monitoring coordinatios. The code has four options for wind field based on observations from SRS meteorological towers and forecasts from the NWS; however, in each case the wind field does not vary in space but may vary in time. For instance, one option uses the most recent wind data at the release site and allows it to vary in ti,ne according to a Model Output Statistics (MOS) forecast. MOS forecasts employ regression equations to link the observed tower data with predictions from the National Weather Service (NWS) Limited Fine Mesh (LFM) model. A single $15 \mathrm{~min}$ release duration is used for "puff" calculations, or the user may specify the release duration for "plume" predictions. Dose or concentration estimates are determined for nnsite and offsite locations. The dose or concentration estimates are automatically printed out in tabular form and graphically depicted as contours overlaid on SRS background maps.

\subsection{DPUF Code, Version 3.1}

The 2DPUF code ${ }^{1,9}$ (version 3.1 ) is a sequential Gaussian model designed to predict more complex concentration distributions on and off-site to obtain accurate dosimetry calculations. 2DPUF can produce both short-range and long-range forecasts because of the meteorological data that are employed. This program is used to determine the environmental consequences of an accidental release of hazardous materials from SRS production facilities and to support emergency response activities. The code has three options for the wind field based on observaiions from SRS meteorological towers and observations and forecasts from the NWS. The wind field may either vary in time but not in space for a "local" calculation, or may vary in space and in time for "regional" calculation. For instance, $N^{\text {' }} \mathrm{S}$ hourly surface observations and available upper-air observations throughout the southeast can be used to generate a regional wind field that varies horizontally. NWS prediction models and MOS can also be used to calculate a time-dependert wind field that does not vary in space. The total duration of the release is specified by the user. Then, the emission is simulated as a series of "puffs", each with a 15 min duration. This is significantly different than PUFF/PLUME which treats a prolonged release as a "plume" instead of a series of "puffs". As in PUFF/PLUME, dose or concentration estimates are determined for onsite and offsite locations. Dose estimates are automatically printed out in tabular form and graphically depicted as contours overlaid on SRS background maps.

\subsection{DESCRIPTION OF THE ATMOSPHERIC MODELS}

Although the basic Gaussian prediction portion of the code has changed little in the past several years, this model has undergone some modifications due to upgrades in computer hardware and improved graphical capabilities. A description of the WIND system atmospheric models is 
necessary to assess the accuracy of the mathematical framework, realism of the physical processes, and appropriateness of the assumptions.

\subsection{Representation of the Physical Processes}

\subsubsection{AREA EVACUATION}

The AREA EVACUATION model on the WIND system has been available for emergency response purposes for several years. The AREA EV FCUATION code is a simple, straight line, nondepositing, reflecting Gaussian model. It was designed to predict the movement $\mathrm{c}$ potential releases close to the reactor areas, necessitating quick computations. Local meteorological observations are used to calculate the plume direction, plume width, and concentratior, or dose estimates in the immediate vicinity of the release.

The transport and dispersion of pollutants in the atmospheric can be described by the conservation of mass equation. An analytic solution to the conservation of mass equatic . . in be obtained when certain simplifications are made. The analytic solution used by AKEA EVACUATION is obtained by assuming a continuous point source and constant meteorological conditions. This solution takes on the Gaussian form and its derivation can be found in many meteorological and air pollution texts ${ }^{10}$. The Gaussian solution used by the AREA EVACUATION model describing the centerline ground-level concentration for chemical releases, $\chi_{c}(\mathrm{ppm})$, is given by

$\chi_{c}=\frac{Q_{c}}{\pi \sigma_{y} \sigma_{z} V} \exp \left[-\frac{1}{2}\left[\frac{h}{\sigma_{z}}\right]^{2}\right] T \frac{C_{1}}{M} \frac{C_{2}}{C_{3}}$

and for radionuclide releases, $\chi_{d}\left(r e m ~ h r^{-1}\right)$, is given by

$\chi_{d}=\frac{Q_{d}}{\pi \sigma_{y} \sigma_{z} V} \exp \left[-\frac{1}{2}\left[\frac{h}{\sigma_{z}}\right]^{2}\right] \exp \left[-\frac{t \ln (2)}{L}\right] D C_{4}$

Here, $\sigma_{y}$ is the horizontal diffusion parameter normal to the direction of the wind $(m), \sigma_{z}$ the vertical diffusion parameter $(\mathrm{m}), \mathrm{V}$ the wind speed $\left(\mathrm{m} \mathrm{s}^{-1}\right)$, and $\mathrm{h}$ the release height $(\mathrm{m})$. For chemical releases, $Q_{c}\left(\right.$ lbs $\left.\mathrm{min}^{-1}\right)$ is the source strength, $T(K)$ the temperature, $M$ the molecular weight of the chemical, $C_{1}(82.1)$ a conversion factor obtained from the equation of state, and $\mathrm{C}_{2}\left(453.5924 \mathrm{~g} \mathrm{lbs}^{-1}\right)$ and $\mathrm{C}_{3}\left(60 \mathrm{~s} \mathrm{~min}^{-1}\right)$ are constants. For radionuclide releases, $\mathrm{Q}_{\mathrm{d}}(\mathrm{Ci}$ $\mathrm{min}^{-1}$ ) is the source strength $\$(\mathrm{~s})$ the time, $\mathrm{L}(\mathrm{s})$ the half-life of the radionuclide, $\mathrm{D}$ (rem $\mathrm{m}^{3}$ $\left.\mathrm{Ci}^{-1} \mathrm{~s}^{-1}\right)$ the dose conversion factor, and $\mathrm{C}_{4}\left(60 \mathrm{~min} \mathrm{hr}{ }^{-1}\right)$ a constant. The dose conversion factor is based on a 50-year committed effective dose equivalent assuming a breathing rate of $3.81 * 10^{-4} \mathrm{~m}^{3} \mathrm{~s}^{-1}$ for an adult ${ }^{11}$. Equation (2) includes the radioactive decay of a specific isotope. Both the concentration predicted by Eq. (1) and the dose predicted by Eq. (2) are functions of space and time.

The horizontal diffusion parameter, $\sigma_{y}$, is based on an expression derived by Pasquill ${ }^{12}$ and is given by:

$\sigma_{\mathrm{y}}=\sigma_{\mathrm{a}} \times \mathrm{f}\left(\mathrm{x}_{\mathrm{k}}\right)$ 
$f\left(x_{k}\right)=\frac{x_{k}{ }^{-0.2}}{1.67+0.3\left[\frac{\left|1-x_{k}^{-0.2}\right|}{0.48}\right]^{0.5}} \quad$ for $x_{k}<10 k m$

$f\left(x_{k}\right)=0.33\left[\frac{10}{x_{k}}\right]^{0.5} \quad$ for $x_{k}>10 \mathrm{~km}$

where $\mathrm{x}_{\mathbf{k}}(\mathrm{km})$ is the downwind distance, and $\sigma_{\mathbf{a}}$ is the standard deviation of the horizontal wind fluctuation derived from observed data at SRS meteorological towers. The vertical diffusion parameter, $\sigma_{2}$, is based on formulas presented by Briggs ${ }^{13}$ and is given by:

$$
\begin{array}{ll}
\sigma_{z}=0.20 \times & \text { for stability class A, } \sigma_{e}>25 \\
\sigma_{z}=0.12 \times & \text { for stability class B, } 20<\sigma_{e}<25 \\
\sigma_{z} \risingdotseq 0.08 \times(1+0.0002 x)^{-1 / 2} & \text { for stability class C, } 15<\sigma_{e}<20 \\
\sigma_{z}=0.06 \times(1+0.0015 x)^{-1 / 2} & \text { for stability class } D, 10<\sigma_{e}<15 \\
\sigma_{z}=0.03 \times(1+0.0003 x)^{-1} & \text { for stability class E, } 5<\sigma_{e}<10 \\
\sigma_{z}=0.02 \times(1+0.0003 x)^{-1} & \text { for stability class } \mathrm{F}, \sigma_{e}<5
\end{array}
$$

where $x(m)$ is the downwind distance. The values of $\sigma_{e}$ in Eqs. (4a) - (4f) for each of the stability classes are 1.43 times greater than those defined by Garrett and Murphy 8 so that the same amount of dispersion is implied in both the horizontal and vertical directions. Since $\sigma_{\mathrm{e}}$ is used only to define the appropriate stability class, estimates of dose or concentration are no different than those given by Garrett and Murphy8.

AREA EVACUATION assumes that transport occurs over flat terrain. Additional assumptions have been made for the SRS emergency response application which will be discussed in subsequent sections.

\subsubsection{PUFF/PLUME}

The underlying physical representation of PUFF/PLUME is similar to AREA EVACUATION, except that it simulates the transport of pollutants as a series of straight-line downwind segments. These segments are determined by hourly averaged values of wind speed and wind direction beginning after the time of the release. During each of the hourly segments, the meteorological conditions are assumed to be constant so that a similar analytic Gaussian solution to Eqs. (1) and (2) can be obtained. In this way, PUFF/PLUME is able to vary the plume direction in time. The Gaussian solution used by the PUFF/PLUME model describing the centerline ground-level concentration for continuous chemical releases, $\chi_{c}(\mathrm{ppm})$, is given by

$\chi_{c}=\frac{Q_{c}}{\pi \sigma_{y} \sigma_{z} V} \exp \left[-\frac{1}{2}\left[\frac{h}{\sigma_{z}}\right]^{2}\right] T \frac{C_{1}}{M_{1}} \frac{C_{2}}{C_{3}}$

and for radionuclide releases, $\chi_{d}$ (rem), is given by 
$\chi_{d}=\frac{Q_{d}}{\pi \sigma_{y} \sigma_{z} V} \exp \left[-\frac{1}{2}\left[\frac{h}{\sigma_{z}}\right]^{2}\right] \exp \left[-\frac{t \ln (2)}{L}\right] D P$

where the notation is the same as in Eqs. (1) and (2) and $P(\mathrm{~min})$ is the total release period of the plume, $Q_{c}\left(\right.$ lbs min $\left.{ }^{-1}\right)$ is the source strength for chemical releases, and $Q_{d}\left(C i m^{-1}\right)$ is the source strength for radionuclide releases. The diffusion parameters in Eqs. (5) and (6) are the same as Eqs. (3) and (4).

When the release duration is relatively small, the transport of the pollutant behaves more like a puff. In this case, the analytic solution to the conservation of mass equation can be obtained by assuming an instantaneous point source and constant meteorological conditions ${ }^{12}$. The Gaussian solution used by the PUFF/PLUME model describing the ground-level concentration for instantaneous chemical releases, $\chi_{c}(\mathrm{ppm})$, at the center of the puff is given by

$\chi_{c}=\frac{2 Q_{c}}{(2 \pi)^{3 / 2} \sigma_{x} \sigma_{y} \sigma_{z}} \exp \left[-\frac{1}{2}\left[\frac{h}{\sigma_{z}}\right]^{2}\right] T \frac{C_{1}}{M} C_{2}$

and for radionuclide releases a dose rate, $\chi_{d}\left(\right.$ rem s $\left.{ }^{-1}\right)$, is given by

$\chi_{d}=\frac{2 Q_{d}}{(2 \pi)^{3 / 2} \sigma_{x} \sigma_{y} \sigma_{z}} \exp \left[-\frac{1}{2}\left[\frac{h}{\sigma_{z}}\right]^{2}\right] \exp \left[-\frac{t \ln (2)}{L}\right] D$

where the notation is the same as in Eqs. (1) and (2) and $\sigma_{\mathrm{x}}$ is the along wind horizontal diffusion parameter that is assumed to be equal to $\sigma_{y}, Q_{c}$ (lbs) is the source strength for chemical releases, and $Q_{d}(C i)$ is the source strength for radionuclide releases. Note that the source strength for a puff is given in total amount released, but the source strength for a plume in Eqs. (5) and (6) is defined as a rate. PUFF/PLUME can only predict the transport and diffusion of one puff downwind of the source. For constant meteorological conditions, Eq. (8) can be integrated in time to obtain a dose, $\chi_{d}$ (rem), given by

$\chi_{d}=\frac{Q_{d}}{\pi \sigma_{y} \sigma_{z} V} \exp \left[-\frac{1}{2}\left[\frac{h}{\sigma_{z}}\right]^{2}\right] \exp \left[-\frac{t \ln (2)}{L}\right] D$

Equation (9) is used by PUFF/PLUME for radionuclides instead of Eq. (8) .

The diffusion parameters, $\sigma_{y}$ and $\sigma_{z}$, for a puff in Eqs. (7) and (8) are based on an expression derived by F. B. Smith and documented by Pasquill 14 and are given by:

$\sigma_{y}=0.22 \sigma_{\mathrm{a}} \mathrm{x}$

$\sigma_{\mathrm{z}}=0.3146 \sigma_{\mathrm{e}} \mathrm{x}$

where $\sigma_{\mathrm{a}}$ is the vertical standard deviation of the wind fluctuation derived from observed data at SRS meteorological towers. Equation (11) is similar to Garrett and Murphy ${ }^{8}$ except that it has been multiplied by 1.43 . This factor is used to produce dispersion that is the same in both the horizontal and vertical directions. When these diffusion parameters defined by Eqs. (10) and (11) become larger than those calculated by Eqs. (3) or (4), they are determined from Eqs. (3) or (4) downwind from that point. This restricts the size of the puff large distances downwind of the source since the diffusion parameters determined from Eqs. (10) and (11) are normally larger than those citermined from Eqs. (3) and (4). 
In addition, PUFF/PLUME computes wet or dry deposition which acts as a sink and reduces the dose for radionuclide releases as given by Eqs. (6) and (9). Denosition includes gravitational settling, rainout, and cepletion due to interactions with the surface vegetation ${ }^{8}$. As in AREA EVACUATION, no terrain effects are included in these formulations.

\subsubsection{DPUF}

The underlying physical representation of 2DPUF is similar to the puff portion of PUFF/PLUME, except that it simulates multiple puffs transported downwind of the source. Each puff has its own trajectory and is :.mulated as a series of straight-line downwind segments. These segments are determined by hourly averaged values of wind speed and wind direction beginning after the time of the release. In contrast to PUFF/PLUME, the meteorological conditions are interpolated in time between these hourly values. 2DPUF is particularly useful for simulating long-term releases into a time-dependent wind field. The ground-level dose from each of the puffs is summed over the entire domain to produce a plume downwind of the source. The Gaussian solution used by the 2DPUF model describing the ground-level dose, $\chi_{d}$ (rem), for each puff of a radionuclide release is given by

$$
\begin{aligned}
& R=\frac{2 Q_{d}}{(2 \pi)^{3 / 2} \sigma_{x} \sigma_{y} \sigma_{z}} \exp \left[-\frac{1}{2}\left[\frac{h}{\sigma_{z}}\right]^{2}\right] \exp \left[-\frac{1}{2}\left[\frac{d}{\sigma_{y}}\right]^{2}\right] \exp \left[-\frac{t \ln (2)}{L}\right] D \\
& \chi_{d}=\int_{0}^{T} R d t
\end{aligned}
$$

where the notation is the same as in PUFF/PLUME and $Q_{d}(\mathrm{Ci})$ is the source strength for each puff, $d$ the horizontal distance from the puff center, $t(s)$ the time, $T$ (s) the total time period, and $\mathrm{R}\left(\mathrm{Ci} \mathrm{s}^{-1}\right)$ the dose rate. To obtain the centerline dose, $\mathrm{d}$ is set equal to zero. As in PUFF/PLUME, $\sigma_{x}$ is assumed to be equal to $\sigma_{y}$.

For constant meteorological conditions, it can be shown that the integrated form of Eq. (12) has an analytic solution of the form

$\chi_{d}=\frac{Q_{d}}{\pi \sigma_{y} \sigma_{z} V} \exp \left[-\frac{1}{2}\left[\frac{h}{\sigma_{z}}\right]^{2}\right] \exp \left[-\frac{1}{2}\left[\frac{d}{\sigma_{y}}\right]^{2}\right] \exp \left[-\frac{t \ln (2)}{L}\right] D$.

This equation is used only in this study to compute an analytic solution that can be compared to the numerical solution produced by 2DPUF for constant meteorological conditions. Equation (13) is not employed by 2DPUF since it assumes time-dependent meteorological conditions.

The diffusion parameters, $\sigma_{y}$ and $\sigma_{z}$, for Eqs. (12) and (13) are based on Eqs. (10) and (11). Unlike PUFF/PLUME, Eqs. (10) and (11) are used for the diffusion parameters in version 3.1 of 2DPUF no matter how large they get. As in PUFF/PLUME, no terrain effects are included in this formulation. In addition, version 3.2 of 2DPUF (not evaluated in this study) includes the deposition scheme and the dispersion parameters employed by PUFF/PLUME.

\subsection{Meteorological Input}

Meteorological towers and the TV tower in the SRS area measure wind speed, wind direction, temperature, and turbulence that is stored in a database that can be accessed by the WIND system. The atmospheric models are designed to read the wind speed (V), wind direction $(\theta)$, 
and the horizontal $\left(\sigma_{2}\right)$ and vertical $\left(\sigma_{\mathrm{e}}\right)$ standard deviations of the wind fluctuations from the meteorological database.

For emergency response purposes, meteorological data must be timely and of high quality if good forecasts of dispersion are to be made by the WIND system atmospheric codes. In order to assure that the meteorological data is of the highest possible quality, the ETS has established procedures to calibrate and maintain the instruments on the meteorological towers 15 . Anemometers measure the wind speed and are accurate to within $0.22 \mathrm{~m} \mathrm{~s}^{-1}$ for speeds below $2.2 \mathrm{~m} \mathrm{~s}^{-1}$ and within $10 \%$ at speeds in excess of $2.2 \mathrm{~m} \mathrm{~s}^{-1}$. Bivanes measure wind direction and are accurate to within $5^{\circ}$. These accuracies are required by DOE regulations; however, the actual accuracy of these instruments are usually well below these values. Wind field parameters are measured at $1.5 \mathrm{~s}$ intervals by the instruments on the towers. Then, the data is averaged over 15 min periods. The data that is collected from the tower network is subject to a quality assurance procedure to made sure the measured data is not an unexpected value ${ }^{16}$. If the quality control procedure finds a data point that lies outside of its expected value, it reassigns it with another value based on data obtained from the other towers. In addition, the availability of the computer network is regularly recorded.

\subsubsection{AREA EVACUATION}

The conditions imposed on the meteorological data that are used in Eqs. (1) - (4) include:

- The code uses the most recent 15-minute averaged wind data at a specific site. In the event wind data is not available at a particular site, quality assured site area mean (SAM) data for that 15-minute period are used. The flow field and stability of the atmosphere in the model does not vary in time or space.

- If $\mathrm{V}, \sigma_{\mathrm{a}}$, or $\sigma_{\mathrm{e}}$ are zero, the program does not generate a plot. The Gaussian solutions described by Eqs. (1) and (2) do not exist when the variables in the denominator are zero.

- If $\sigma_{\mathrm{a}}$ exceeds 30 degrees, it is set equal to 30 degrees.

- If $\sigma_{\mathrm{e}}$ exceeds 21 degrees, it is set equal to 21 degrees.

- The diffusion parameters are a function of $\sigma_{a}, \sigma_{e}$, distance from the source, and atmospheric stability. Both $\sigma_{y}$ and $\sigma_{z}$ are based on formulations by Pasquill ${ }^{12}$ and Briggs ${ }^{13}$ as described by Eqs. (3) and (4).

- The maximum value of $\sigma_{\mathrm{z}}$ is assumed to be 0.8 times the height of the boundary layer, $\mathrm{H}$ to prevent the plume from growing above the mixed layer and producing urealistic results ${ }^{9}$. The height of the boundary layer is assumed to be a constant $500 \mathrm{~m}$.

- The Gaussian solution described by Eqs. (1) or (2) does not take into account any effects of terrain on the flow field and the dispersion.

The upper bounds on $\sigma_{\mathrm{a}}$ and $\sigma_{\mathrm{e}}$ restrict the horizontal and vertical extent of the plume in extremely unstable atmospheric conditions. Conservative concentration or dose rate estimates are made by the model in this case.

\subsubsection{PUFF/PLUME}

The conditions imposed on the meteorological data that are used in Eqs. (5) - (11) include:

- The code uses wind field data from the SRS meteorological tower closest to the specified release location. When the release location is not one of the default location areas, site area mean (SAM) wind field data are used for the initial forecast segment.

- The wind field may be entered manually by the user, or it is specified by default values. If the user enters the data manually, hourly values of meteorological data must be used. 
The default wind field uses the most recent 15-minute averaged wind data at the area specified. In the event wind data is not available at a particular site, quality assured SAM data for that 15-minute period are used. Subsequent segments use wind field forecasts that are based on Modeled Output Statistics (MOS) produced by the National Meteorological Center (NMC) for the SRS site. In either case, the wind field is allowed vary in time, but not in space.

- During each of the hourly segments after the release, the meteorological conditions are assumed to be constant so that an analytic Gaussian solution for a puff or plume can be employed.

- If $\mathrm{V}, \sigma_{\mathrm{a}}$, or $\sigma_{\mathrm{e}}$ are zero, the program uses SAM data for the wind field. The Gaussian solutions described by Eqs. (5) - (9) do not exist when the variables in the denominator are zero.

- The diffusion parameters are a function of $\sigma_{2}, \sigma_{e}$, distance from the source, and atmospheric stability. For a plume, $\sigma_{\mathrm{y}}$ and $\sigma_{\mathrm{z}}$ are based on formulations by Pasquill 12 and Briggs 13 as described by Eqs. (3) and (4). For a puff, $\sigma_{y}$ and $\sigma_{z}$ are based on formulations by Pasquill 14 as described by Eqs. (10) and (11) with the assumption that are they not to exceed those computed by Eqs. (3) and (4).

- The maximum value of $\sigma_{z}$ is assumed to be 0.8 times the height of the boundary layer, $\mathrm{H}$ to prevent the plume from growing above the mixed layer and producing urealistic results ${ }^{9}$. The height of the boundary layer varies between $300 \mathrm{~m}$ during the late evening to $1000 \mathrm{~m}$ during the late afternoon. The values are specified at hourly intervals and are based on climatological values that are not seasonally dependent. The model will only allow the depth of the boundary layer to grow in time. If the climatological values decrease during the simulation period, the model will keep the boundary layer depth constant.

- The Gaussian solution described by Eqs. (5) - (9) does not take into account any effects of terrain on the flow field and the dispersion.

Some observations have shown that the width of a puff can be significantly less than the width predicted by the diffusion parameters defined by Eqs. (10) and (11). The diffusion parameters in PUFF/PLUME for a puff are not allowed to exceed those computed by Eqs. (3) and (4) for a plume to reduce the size of the puff at large distances downwind of the source.

\subsubsection{DPUF}

The conditions imposed on the meteorological data that is used in Eq. (12) include:

- The code uses SAM wind field data for the specified release location instead of the data from the closest meteorological tower.

- The wind field may be entered manually by the user, or it is specified by one of two default methods that are available. If the user enters the data manually, hourly values of meteorological data must be used. In this case, the wind field is allowed to vary in time, but not in space. One default method allows the user to choose a local-area forecast which employs the most recent 15-minute averaged SAM wind data is used for the first time step. Subsequent segments use wind field forecasts that are based on Modeled Output Statistics (MOS) produced by the National Meteorological Center (NMC) for the SRS site. In this case, the wind field is allowed to vary in time, but not in space. The second default method allows the user to choose a regional-area forecast which employs a wind field that is based on wind data from up to nine National Weather Service (NWS) radiosonde stations and 44 NWS surface stations and SAM data. In this case, the wind field is allowed to vary in space and time. 
- The meteorological conditions are not assumed to be constant during the hourly segments as in PUFF/PLUME. Instead, meteorological values are interpolated in time between the hourly values so that there is a gradual change in the wind field in time.

- For the local-area forecast, meteorological data is interpolated onto a horizontal grid with a $0.5 \mathrm{~km}$ spacing. For the regional-area forecast, the horizontal grid spacing is 5 $\mathrm{km}$. Horizontal grids are constructed for each of eleven vertical levels between 100 and $2000 \mathrm{~m}$ above the ground for the regional-area forecast. Then, the interpolated wind field is averaged vertically to produce a single $60 \mathrm{~m}$ wind field that is used for the dispersion calculations.

- If $\mathrm{V}, \sigma_{\mathrm{a}}$, or $\sigma_{\mathrm{e}}$ are zero, the Gaussian solution described by Eq. (12) is not valid. The user must be sure that these variables are not zero when entering meteorological data manually. In addition, 2DPUF will not accept boundary-layer heights that are zero.

- The diffusion parameters are a function of $\sigma_{a}, \sigma_{e}$, distance from the source, and atmospheric stability. Both $\sigma_{y}$ and $\sigma_{z}$ are based on formulations by Pasquill ${ }^{14}$ as described by Eqs. (10) and (11).

- The maximum value of $\sigma_{z}$ is assumed to be 0.8 times the height of the boundary layer, $\mathrm{H}$ to prevent the plume from growing above the mixed layer and producing urealistic results ${ }^{9}$. The height of the boundary layer is the larger of (1) $125^{*} \mathrm{~V}$, or (2) a value from a climatological data base. The values of $\mathrm{H}$ in the climatological data base vary between $300 \mathrm{~m}$ during the late evening to $1000 \mathrm{~m}$ during the late afternoon. These values are specified at hourly intervals and are not seasonally dependent. The model will only allow the depth of the boundary layer to grow in time. If the climatological values decrease during the simulation period, the model will keep the boundary layer depth constant.

- The Gaussian solution described by Eqs. (12) does not take into account any effects of terrain on the flow field and the dispersion.

The growth of the puff in 2DPUF differs from PUFF/PLUME in that 2DPUF does not restrict the size of the diffusion parameters downwind of the source.

\subsection{Source Input}

\subsubsection{AREA EVACUATION}

The Gaussian model described by Eqs. (1) and (2) requires source strength data for a continuous (plume) point source that may be either a chemical or radioactive material. The numerical code requires the user to specify the magnitude of this source term. There are several assumptions relating to the source strength including:

- $\quad$ Eight different predetermined release locations within the SRS that are most likely to have significant accidental releases can be chosen. These locations include the $M(A)$, $\mathrm{C}, \mathrm{D}, \mathrm{F}, \mathrm{H}, \mathrm{K}, \mathrm{P}$, and $\mathrm{L}$ areas. Each of these areas has a meteorological tower located near the production facility stacks with instruments $61 \mathrm{~m}$ above the ground so that accurate local wind data can be obtained.

- The source strength of the release, $Q_{c}$ or $Q_{d}$, is constant in time. If this source term is not known by the user, a default value can be used. The default value is assumed to be $60 \mathrm{Ci} \mathrm{min}^{-1}$ for a radionuclide release or $60 \mathrm{lbs} \mathrm{min}^{-1}$ for a chemical release.

- The release height, $h$, is assumed to be $40 \mathrm{~m}$ above the surface. This does not correspond to the release height of the SRS production facility stacks; however, this is intended to be a mean value because the release could occur at a number of levels. This value will also lead to a more conservative estimate of the dose rate. The user cannot change the release height. 
- The initial horizontal standard deviation, $\sigma_{y}$, at the release site is assumed to be $3.048 \mathrm{~m}$ (10 ft) because this is the width of a typical production facility stack. The initial vertical standard deviation, $\sigma_{z}$, is also assumed to be $3.048 \mathrm{~m}$ so that the initial point source is spherical. The user is not allowed to change these values.

- The AREA EVACUATION code allows the users to chose one of 16 radionuclides or 3 hazardous chemicals. The specific radionuclides, and their half-life and dose factors can be found in reference 1.

- The temperature for all the chemicals in Eq. (1) is assumed to be $273 \mathrm{~K}$.

- The current time is the default release time. The user is not allowed to change the release time.

- The default release is infinite because of the continuous source release assumption.

The reason default values of $Q_{c}$ or $Q_{d}$ have been chosen is that during emergency response situations there may be a period of time when no source release data is known, but the atmospheric models need to be executed. When this occurs, default values for the source term are used in the models.

\subsubsection{PUFF/PLUME}

The Gaussian model described by Eqs. (5) - (9) require source strength data for a continuous (plume) or instantaneous (puff) point source that may be either a chemical or radioactive material. The numerical code requires the user to specify the magnitude of this source term. There are several assumptions relating to the source strength including:

- As in AREA EVACUATION, eight different predetermined release locations within the SRS that are most likely to have significant accidental releases can be chosen. These locations include the A (M), C, D, F, H, K, P, and $L$ areas. The user can specify another location (using latitude and longitude coordinates) if it is necessary.

- The source strength of the release, $Q_{c}$ or $Q_{d}$, is constant in time. If this source term is not known by the user, a default value can be used. For a plume, the default value is assumed to be $60 \mathrm{Ci} \mathrm{min}-1$ for a radionuclide release or $60 \mathrm{lbs} \mathrm{min}^{-1}$ for a chemical release. For a puff, the default value is assumed to be $60 \mathrm{Ci}$ for a radionuclide release or $60 \mathrm{lbs}$ for a chemical release.

- The release height, $h$, is assumed to be $61 \mathrm{~m}$ above the surface. This corresponds to the release height of the SRS production facility stacks. The user can change the release height if it is necessary.

- The initial horizontal standard deviation, $\sigma_{\mathrm{y}}$, at the release site is assumed to be $3.048 \mathrm{~m}$ (10 ft) because this is the width of a typical production facility stack. The initial vertical standard deviation, $\sigma_{\mathrm{z}}$, is also assumed to be $3.048 \mathrm{~m}$ so that the initial point source is spherical. These values can be changed by the user if it is necessary.

- $\quad$ The PUFF/PLUME code allows the user to chose one of 16 radionuclides, 3 hazardous chemicals, or noble gases. The specific radionuclides, and their half-life and dose factors can be found in reference 1 .

- The temperature for all the chemicals in Eqs. (5) and (7) is assumed to be $293 \mathrm{~K}$.

- The current time is the default release time. The user may specify when the release occurred if it is necessary.

- The default release duration is $15 \mathrm{~min}$ for a puff and $60 \mathrm{~min}$ for a plume. The user may change these values if more accurate information is known.

As in AREA EVACUATION, default values of $Q_{c}$ or $Q_{d}$ are sometimes necessary the source release data may not be known. 


\subsection{3 $2 D P U F$}

The Gaussian model described by Eq. (12) requires source strength data for an the point source (radioactive material only). The numerical code requires the user to specify the magnitude of this source term. There are several assumptions relating to the source strength including:

- As in AREA EVACUATION, eight different predetermined release locations within the SRS that are most likely to have significant accidental releases can be chosen. These locations include the $\mathrm{M}(\mathrm{A}), \mathrm{C}, \mathrm{D}, \mathrm{F}, \mathrm{H}, \mathrm{K}, \mathrm{P}$, and $\mathrm{L}$ areas. The user can specify another location (using latitude and longitude coordinates) if it is necessary.

- The source strength of the release, $Q_{d}$, may vary in time. No default value is assigned by the code. The user may input the source data on time intervals of one hour.

- The release height, $h$, is assumed to be $61 \mathrm{~m}$ above the surface. This corresponds to the release height of the SRS production facility stacks. The user can change the release height if it is necessary.

- The initial horizontal standard deviation, $\sigma_{y}$, at the release site is assumed to be $3.048 \mathrm{~m}$ (10 ft) because this is the width of a typical production facility stack. The initial vertical standard deviation, $\sigma_{\mathrm{z}}$, is also assumed to be $3.048 \mathrm{~m}$ so that the initial point source is spherical. The user is not allowed to change these values.

- The 2DPUF code allows the user to chose any number of 27 radionuclides (multiisotopic releases). A sequential Gaussian puff calculation is made for each radionuclide chosen, then the resulting doses are summed together to obtain a total dose. The specific radionuclides, and their half-life and dose factors can be found in reference 1.

- The current time is the default release time. The user may specify when the release occurred if it is necessary.

- The default release duration is $15 \mathrm{~min}$ for a puff and $60 \mathrm{~min}$ for a plume. The user may change these values if more accurate information is known.

- 2DPUF can read in source term information from the Reactor Accident Code (RAC) that is designed to compute the release from a fuel damage incident at an SRS reactor facility.

As in AREA EVACUATION, default values of $Q_{c}$ or $Q_{d}$ are sometimes necessary the source release data may not be known.

\subsection{Numerical Procedure}

Documentation on how to execute the WIND system atmospheric models will not be included here, but a detailed description can be found in reference 1 . This section will focus on the type of output that is produced by the atmospheric models in relation to emergency response purposes.

\subsubsection{AREA EVACUATION}

Some characteristics of the numerical procedure and graphical output produced by the model includes.

- The concentration is calculated at the centerline at 75 evenly spaced locations downwind of the source at $100 \mathrm{~m}$ increments. Thus, the plume is calculated to $7.5 \mathrm{~km}$ downwind of the source. This distance is less than the radius of the site; therefore, all of the calculations are made for onsite locations.

- There are no chemical reactions in the atmosphere resulting from the release.

- Contours of concentration or dose are plotted on a map centered on the release location. The contours are labeled in ppm for chemical releases and rem $\mathrm{hr}^{-1}$ for radionuclide 
releases. The width of the plot is $5 \mathrm{mi}$ (about $8 \mathrm{~km}$ ). The resulting map displays the roads, railroads, and rivers and streams, in the immediate vicinity surrounding the release location.

- If for some reason the concentration is negative (not realistic), the program aborts leaving a message for the user.

The contours of concentration or dose plotted the on a map of the site to help emergency response personnel plan possible evacuation routes.

\subsubsection{PUFF/PLUME}

Some characteristics of the numerical procedure and graphical output produced by the model includes.

- The concentration is calculated at the centerline up to 72 time intervals from the of the release. Thus, the spacing of these locations will be uneven if the wind speed or direction changes in time. The user has some control as to how far downwind the calculations are made by specifying a time step used in the calculations. The time step can be either $1,2,3,4,5$, or $10 \mathrm{~min}$. If a short time step is used, the plume or puff will not travel far downwind. For instance, for low wind speeds of $1 \mathrm{~m} \mathrm{~s}^{-1}$ with a 1 min time step, a puff can travel approximately $4.3 \mathrm{~km}$ dcwnwind, and will probably remain on the site. If a long time step is used, the plume or puff can travel a longer distance downwind. If a 10 min time step is chosen with a wind speed of $1 \mathrm{~m} \mathrm{~s}^{-1}$, a puff can travel approximately $43 \mathrm{~km}$ downwind, and will move off-site. Therefore, PUFF/PLUME can produce concentration or dose estimate for on-site and off-site locations.

- No chemical reactions in the atmosphere are accounted for during the release.

- Contours of concentration or dose are plotted on a map centered on the release location. The contours are labeled in ppm for chemical releases and rem for radionuclide releases. Several plots can be made. The smallest plot is about $30 \mathrm{~km}$ wide and displays the entire SRS with roads and the area locations. Three regional maps can be displayed as well (CSRA, South Carolina and Georgia, southeastern U. S). This is useful if the plume or puff travels more than $30 \mathrm{~km}$ downwind.

- The program will not generate a plot if there is no concentration or dose to be contoured. This may be the case if inaccurate data has been entered.

The contours of concentration or dose plotted the on a map of the site to help emergency response personnel plan possible evacuation routes.

\subsubsection{DPUF}

Some characteristics of the numerical procedure and graphical output produced by the model includes.

- The dose is calculated for $24 \mathrm{hr}$ or until the puff crosses the $90 \mathrm{~km}$ radius from the SRS center for the local calculation. For the regional-area forecast, the model runs for $24 \mathrm{hr}$ or until the puff crosses the $300 \mathrm{~km}$ radius from the SRS center. The time step is allowed to change in time so that small time steps are used initially after the release and progressively larger time steps are used farther downwind. The small time steps initially are necessary to resolve the smaller sized puffs that are released. The initial time step is $20 \mathrm{~s}$. As the puff grows downwind by diffusion, larger times steps may be used to resolve the structure of the puff. The variable time step scheme is employed to reduce the run-time of the model while still resolving the puffs as accurate as possible. 
The time step is based on the atmospheric stability and wind speed. The spacing of the centerline locations will be uneven if the wind speed or direction changes in time. 2DPUF can produce concentration or dose estimate for on-site and off-site locations.

- No chemical reactions in the atmosphere are accounted for during the release.

- Contours of concentration or dose are plotted on a map centered on the release location. The contours are labeled in ppm for chemical releases and rem for radionuclide releases. Several plots can be made. The local-area calculation will produce a plot that is about $30 \mathrm{~km}$ wide and displays the entire SRS with roads and the area locations. The regional-area calculation will produce a plot for the South Carolina and Georgia region.

- The program will not generate a plot if there is no concentration or dose to be contoured. This may be the case if inaccurate data has been entered.

The contours of concentration or dose plotted the on a map of the site to help emergency response personnel plan possible evacuation routes.

\subsection{Appropriateness of the Model Assumptions}

This section will look at consequences of the assumptions made for each atmospheric model. The effect of some of the assumptions of the models will be examined in detail in section 4 . In addition, the advantages and disadvantages will be discussed in relation to emergency response purposes. The formulation of the atmospheric models will be compared to similar models used at other DOE sites ${ }^{17}$.

Many assumptions and conditions have been employed by AREA EVACUATION, PUFF/PLUME and 2DPUF so that the Gaussian method can be retained as described in sections 3.1 - 3.4. These assumptions limit the physical representation of the atmosphere and, therefore, the behavior of the resulting plume. The assumptions of the wind field, boundary layer depth, release height, and terrain will be discussed in the following paragraphs in relation to their impact on the doses or concentrations predicted by each of the atmospheric models.

A trained meteorologist should be able to account for these discrepancies during a model execution.

\subsubsection{AREA EVACUATION}

In general, straight-line Gaussian models suffer from limitations including the gross simplification of the atmospheric properties, the inability to represent recirculation of pollutants in complex terrain, and the erroneous use of one stability class at a given time to represent turbulent mixing over heterogeneous terrain. Nevertheless, these models are being used extensively by the DOE, NRC, and EPA to predict the dispersion from stack releases because (1) results may be obtained in a very short period of time and (2) the straight-line Gaussian assumption is adequate over short periods of time and distances.

AREA EVACUATION predicts dose rates or concentrations up to $7.5 \mathrm{~km}$ downwind of the source. Since wind speeds over the site are typically between 2 and $10 \mathrm{~m} \mathrm{~s}^{-1}$, transport across the model domain would occur in roughly 13 to $63 \mathrm{~min}$. Average wind directions and wind speeds usually do not vary significantly during this short period of tirne; therefore, horizontal homogeneity and constant wind speed and direction are reasonable assumptions for forecasts in the area immediately surrounding the release location. However, wind speed and direction at a particular location can change significantly over a longer period of time or if a significant weather pattern moves into the SRS area such as a cold front or a thunderstorm. The Gaussian assumption also restricts the magnitude of the wind speed because extremely small wind speeds will produce infinite dose rates or concentrations as determined by Eqs. (1) and (2); 
however, wind speeds less than $2 \mathrm{~m} \mathrm{~s}^{-1}$ occur less than $1 \%$ of the time at SRS meteorological towers ${ }^{18}$. Ir. addition, vertical wind shear is neglected; however, this may not be very important for the short distances used by this model.

Errors in the prediction of dose rates or concentration could also arise from small errors in the measurement of wind direction and speed as recorded by the SRS meteorological instrumentation as described in section 3.2. Using an accuracy estimates of $5^{\circ}$ for the wind direction would lead to an $0.65 \mathrm{~km}$ error in the prediction of the centerline location of the plume $7.5 \mathrm{~km}$ downwind of the source. The largest possible wind speed errors would result in an arrival time error of $6.7-1.1 \mathrm{~min} 7.5 \mathrm{~km}$ downwind of the source for wind speeds ranging from $2.2-10 \mathrm{~m} \mathrm{~s}^{-1}$. These arrival time errors are relatively small considering the total travel time would be $63 \mathrm{~min}$ for a $2 \mathrm{~m} \mathrm{~s}^{-1}$ wind speed and $13 \mathrm{~min}$ for a $10 \mathrm{~m} \mathrm{~s}^{-1}$ wind speed. The potential errors in the wind direction and speed are probably much larger than what they really are because averaging techniques will eliminate any random errors made by the instruments.

AREA EVACUATION also assumes a constant boundary-layer height, but this parameter actually varies diurnally and seasonally. For periods less than an hour, a constant boundarylayer height may be a satisfactory assumption except early in the morning when mixed-layer growth is expected to be significant. Average mixed-layer depths of $1000-2000 \mathrm{~m}$ are common over the SRS during the afternoon ${ }^{18}$, which is significantly different than the default $500 \mathrm{~m}$ value used by the code. In this case, AREA EVACUATION will produce $:$ more "conservative" estimate of the dose rate. During the evening, when boundary-layer depths can be significantly lower $500 \mathrm{~m}$, the dose rate will be underpredicted

The release of toxic or radiological materials will most likely occur at the production facility stacks; however, releases can occur at other levels. The default stack height of $40 \mathrm{~m}$ used by AREA EVACUATION represents a typical level. If a release occurred at another level, the code may significantly underpredict or overpredict downwind dose rates or concentrations.

Since; the wind field is horizontally homogeneous, the model does not account for any terrain effects. The terrain within the SRS is gently rolling and varies by no more than $100 \mathrm{~m}$; neverth cless, local terrain features and buildings may play an important role in determining the flov; around release locations, especially for surface releases.

\subsubsection{PUFF/PLUME}

PUFF/PLUME allows the meteorological parameters to vary in time, which is a distinct improvement to the formulation in AREA EVACUATION. The accuracy of the trajectory of the puff or the plume will depend on the accuracy of the MOS forecast and the distance from the release location. The MOS forecast is valid only for the SRS, but this wind speed is applied in the trajectory at off-site locations; therefore, errors in the meteorological parameters will increase with distance from the release location. In addition, the accuracy of the MOS forecast will be a function of time since it is based partially on a NWS larger-scale model which will have the smallest errors near the initialization periods at 00 GMT and 12 GMT 8 pm and 8 am EDT). As in AREA EVACUATION, low wind speeds may produce erroneous results since the wind speed appears in the denominator of Eqs. (5) and (6) in the Gaussian solution for a plume. PUFF/PLUME assumes that the wind field is horizontally homogeneous at each time step and it neglects vertical wind shear. This certainly is not true on the regional scale where large-scale weather patterns may significantly distort the flow field.

As in AREA EVACUATION, errors in the prediction of dose rates or concentration could also arise from small errors in the measurement of wind direction and speed as recorded by the SRS meteorological instrumentation. These errors may be more significant because PUFF/PLUME 
performs calculations large distances from the site. Assuming the same accuracy of the meteorological instruments described in section 3.2, a $2.6 \mathrm{~km}(8.7 \mathrm{~km})$ error in the prediction of the centerline location could result $30 \mathrm{~km}(100 \mathrm{~km})$ downwind of the release location. Wind speeds of $2 \mathrm{~m} \mathrm{~s}^{-1}$ would take $250 \mathrm{~min}(833.3 \mathrm{~min})$ to reach $30 \mathrm{~km}(100 \mathrm{~km})$ with a potential error of $24.8 \mathrm{~min}(82.5 \mathrm{~min})$. Wind speeds of $10 \mathrm{~m} \mathrm{~s}^{-1}$ would take $50 \mathrm{~min}(166.7 \mathrm{~min})$ to reach $30 \mathrm{~km}(100 \mathrm{~km})$ with a potential error of $4.5 \mathrm{~min}(15.2 \mathrm{~min})$. These potential errors are still rather small considering all of the other sources of error.

Boundary-layer depth is determined more accurately than AREA EVACUATION since it is based on climatological values; nevertheless significant errors may still occur. As described by Hunter ${ }^{18}$, mixed-layer depths over the SRS during a typical summer afternoon may be significantly greater than the climatological value of $1000 \mathrm{~m}$. In this case, PUFF/PLUME will give a "conservative" estimate of the predicted dose or concentration. However, the boundarylayer depth can be significantly lower than climatological value of $300 \mathrm{~m}$ during the evening hours which would cause the model to predict doses or concentrations that are too low. Another source of error can arise from the growth rate of the boundary-layer, which can be significant in the morning hours. Even though PUFF/PLUME updates the boundary-layer depth every hour, the actual growth of the boundary may occur at a faster rate.

PUFF/PLUME is superior to AREA EVACUATION as far as the source location and the release period. 'The user is able to select the release location to be anywhere within the SRS. The only drawback is that if a release occurs other than the area locations, the SAM winds are used for the initial trajectory. This may not be a good assumption for a local prediction immediate to the release location, but it may not make any difference in the regional calculation. The user is able to specify the release period if it is known so that the downwind dose rates or concentrations are not overpredicted or underpredicted. There is still some potential for error here if inadequate information is known about the source term and its duration. This is a probable occurrence, especially during the initial phase of a release. Default values have been set up, but one must remember that this can lead to a significant error.

As in AREA EVACUATION, terrain effects are not account for. Since PUFF/PLUME simulates regional and well as local transport of pollutants, the effect of terrain on modifying the puff or plume will probably be significant far from the release location.

\subsubsection{DPUF}

The wind field represented by 2DPUF is somewhat more complex than PUFF/PLUME which may lead to a more accurate transport prediction under certain atmospheric conditions. When 2DPUF is executed with the time-dependent wind field, it will have the same assumptions as described in the previous section for PUFF/PLUME with one exception. Since 2DPUF updates the meteorological parameters at every time step, the trajectory of the puff downwind of the release location may be significantly different than the one predicted by the hourlysegmented PUFF/PLUME. It is not entirely clear which method is more accurate and this assumption will be evaluated in section 4. When 2DPUF is executed with a horizontallyvarying wind field, it usually does not vary in time for emergency response applications; therefore, it is most accurate close to source for unsteady synoptic siiuations and at downwind locations for stationary synoptic conditions. Vertical wind shear may play an important role in transport, and is partially accounted for in this method by winds that have averaged vertically to one level. As in AREA EVACUATION, low wind speeds may produce erroneous results.

Unlike PUFF/PLUME which calculates the dose rate or concentration from an analytic equation, 2DPUF numerically integrates Eq. (12).in time. This will likely lead to small numerical errors in the solution. 
As in PUFF/PLUME, boundary-layer depth is based on climatological values and will be influenced by the same errors as described in section 3.5.2. The only difference will be that 2DPUF can incrementally allow boundary-layer growth in time, rather thin just updating the boundary-layer depth every hour. This may be an important feature during the early morning hours when growth of the boundary layer can be rigorous and the dispersion of particulates would be better represented by 2DPUF.

2DPUF has a similar procedure for source location as described in the previous section for PUFF/PLUME. The treatment of the duration of the puffs is different than PUFF/PLUME. In PUFF/PLUME, a puff can be any length that is desired, although longer puffs should be considered plumes. In $2 D P U F$ a long release perird will have many puffs each of $15 \mathrm{~min}$ duration. In this way the spread of the plume will evolve with the time-dependent wind field.

As in AREA EVACUATİON, terrain effects are not account for. Since 2DPUF simulates regional as well as local transport of pollutants, the effect of errain on modifying the puff or plume will probably be significant far from the release location.

\subsubsection{Comparison with other models}

The DOE Subcommittee on Dose Assessment ${ }^{17,19}$ has compared the formulations of various atmospheric/transport models used at DOE sites. It was found that many sites find the need to use straight-line Gaussian models for a variety of recsons. While those reports did not specifically look at AREA EVACUATION, it would probably rank in their A or B class (a relatively simple straight-line Gaussian) ${ }^{17}$. This indicates that AREA EVAC.UATION is probably very similar to other straight-live Gaussian mindels at other DOE sites with a reduction in the variety of the input choices avajiable to the user. PUFF/PLUME and 2DPUF ranked as one of the models with the most sophistication in the DOE community (a $C$ in their ranking system) along with the HARMII, MATHEW/ADPIC, MESOI, MESORAD, TRAC, and ERAD models. This indicates that PUFF/PLUME and 2DPUF are probably adequate and acceptable models to be used in emergency response situations, as long as they have been thoroughly evaluated.

\subsection{COMPARISON AGAINST ANALYTIC SOLUTIONS}

The objective of this evaluation procedure is to test some of the logic in the AREA EVACUATION, PUFF/PLUME, and 2DPUF codes and to verify that the theoretical plume or puff characteristics are being calculated zorrectly. These models compute ground-level concentration or dose based Gaussian equations as described in section 3.1; therefore, it should be relatively easy to verify the numerical resuits.

The parameters $\theta, V, \sigma_{y}, \sigma_{z}, h, Q, L, D$, and $M$ must all be specified correctly in order to determine the conect theoretical concentration, dose rate, or dose. By varying these parameters one at a time, individual logic branches in the atmospheric codes may be tested. Large differences between the numerical results and the analytic solution may indicate an error or an incorrect assumption in the model code. Small differences could be attributed to truncation errors and would indicate the model is predicting the theoretical dispeision characteristics correctly.

An independent program was created for each of the atmospheric codes. These independent programs calculated concentrations or doser based on the straight-line Gaussian solutions described in section 3.1. Both atmospheric models and the independent programs were executed with the same simple meteorological conditions and source parameters. To evaluate 
the coding of the atmospheric models, the numerical results were compared to the appropriate analytic solution. Minor modifications to the AREA EVACUATION, PUFF/PLUME, and 2DPUF codes were necessary to print out a tabular file of the results.

The procedure used to evaluate the numerical codes was as follows:

(1) Default meteorological parameters $\left(\theta, V, H, \sigma_{a}, \sigma_{e}\right)$ and the source parameters $(h, Q, L$, $D, M)$ were defined for the specific radionuclide or chemical to be released. These parameters are designated by case 1 in Tables 1 and 2 .

(2) A file of the predicted dispersion pattern as computed by AREA EVACUATION, PUFF/PLUME, and 2DPUF using the input parameters was created. This file contains $\chi_{\mathrm{d}}$ or $\chi_{c}, \sigma_{\mathrm{y}}$, and $\sigma_{z}$, at each location downwind of the source.

(3) A file of the theoretical dispersion pattern determined by the analytic Gaussian solution given by Eqs. (1) or (2) with the same input parameters as in step (2) was created.

(4) The difference between the numerical results of AREA EVACUATION, PUFF/PLUME, and 2DPUF and the appropriate analytic Gaussian solution were. calculated.

(5) One input parameter for AREA EVACUATION, PUFF/PLUME, 2DPUF, and the appropriate analytic Gaussian solutions was modified.

(6) Steps (2) to (5) were repeated until all of the cases listed in Tables 1 and 2 were completed for each atmospheric model.

\subsection{AREA EVACUATION}

The results as defined by Eq. (1) or (2) for the various cases listed in Tables 1 and 2 are depicted in Figs. 1 - 6. A comparison of the numerical results produced by AREA EVACUATION to the analytic solution is shown Tables $3-17$. The results from case 17 are not listed because they were identical to those in case 1 , except the wind direction has been altered. As indicated by these tables, the AREA EVACUATION model was able to predict the theoretical values out to five significant digits.

The values of $\sigma_{y}$ and $\sigma_{z}$ for various stability classes (cases 1 and $7-11$ ) as calculated by Eqs. (3) and (4) are depicted in Figs. 1 and 2. The variation of $\sigma_{y}$ in Fig. 1 is very similar to Pasquill-Gifford dispersion diagrams reported in the literature ${ }^{20}$. In Fig. 1, stability class A (unstable) produces the largest plume width and stability class $\mathrm{F}$ (stable) produces the smallest plume width. This is intuitively correct because pollutants are dispersed more by the turbulent motions found in an unstable boundary layer. As expected, atmospheric instability also increases the depth of the plume as shown in Fig. 2. The assumption that $\sigma_{z}$ does not exceed $80 \%$ of the mixing depth (500 $\mathrm{m}$ for these cases) appears in the results for stability classes $\mathrm{A}$ and B. The plume depth approaches $400 \mathrm{~m}$ approximately $2.0 \mathrm{~km}$ downwind for stability class $A$ and $3.5 \mathrm{~km}$ downwind for stability class B. The variation of $\sigma_{\mathbf{z}}$ in Fig. 2 is nearly identical to the Brookhaven dispersion diagrams ${ }^{20}$ because AREA EVACUATION employs the same equations ${ }^{8}$. The only difference is that the initial $\sigma_{y}$ and $\sigma_{z}$ are assumed to be the width of the SRS production facility stacks which is approximately $3.04 \mathrm{~m}$.

The dose rates and the concentrations for various types of radionuclides and chemicals (cases 1 -4) are hown in Fig. 3. For these cases, the stability class is D (neutral) and the wind speed is $7.5 \mathrm{~m} \mathrm{~s}^{-1}$. All of the curves in this figure have the same shape, with the peak surface dose rate or concentration $1.0 \mathrm{~km}$ downwind of the elevated source. For the radionuclides in AREA EVACUATION, dose rate depends only upon the dose conversion factcr, $D$, and the half-life, $\mathrm{L}$ which are listed in Table 2. The dose conversion factor for Plutonium-238 is about a factor of ten greater than Tritium Oxide; therefore, the dose rates in Fig. 3 for Plutonium-238 are also a factor of ten larger than those for Tritium Oxide. These calculations are being made close to 
the source so that the travel time is relatively small; therefore, the dose rate is not reduced significantly by radioactive decay.

The dose rate and concentration also depends indirectly on the depth of the mixing layer, $\mathrm{H}$. In Fig. 4, the dose rates for various mixing depths are shown (cases 1 and 5 -6). For stability class $\mathrm{D}$ (neutral), the dose rate is identical for a mixing depth of 500 or $1000 \mathrm{~m}$ because $\sigma_{z}$ never exceeds $400 \mathrm{~m}$ as shown in Fig. 2. For stability class A (unstable), the dose rate is somewhat less than stability class D $2.0 \mathrm{~km}$ downwind of the source because the mixed layer has grown larger, allowing for greater vertical dispersion. This will ultimately lead to a reduced dose rate since the concentration of particulates will decrease with increased vertical dispersion.

The dose rates for various wind speeds (cases 12 - 16) are depicted in Fig. 5. Low wind speeds will not transport particulates from an elevated source downwind at a great rate; therefore, the particulâies can be dispersed vertically near the source and ground-level dose rates will be relatively high. High wind speeds will transport particulates from an elevated source downwind quickly reducing the dose rate at the ground near the source. The shapes of the curves in this figure are identical because of the linear relationship between the dose rate and wind speed in Eq. (2).

The stability of the atmosphere will also have a profound impact on the dispersion of particulates as indicated by the dose rates (cases 7 - 11) in Fig. 6. For unstable cases the plume is dispersed vertically quickly, leading to high dose rates just downwind of the source. Stable atmospheric conditions do not allow the plume to grow significantly, so that the maximum dose rate at the surface will occur far downwind of the source. For these meteorological conditions, stability class A (unstable) produced the maximum ground-level dose rate close to the source. This peak in the dose rate is due to the fact that this was an elevated release where turbulent motions associated with unstable atmospheric conditions would diffuse particulates to the surface rapidly. For all of the cases in this figure, the wind speed is $7.5 \mathrm{~m} \mathrm{~s}^{-1}$ and the mixing depth is $500 \mathrm{~m}$. In reality, unstable atmospheric conditions would lead to increased mixing depths (as much as $3000 \mathrm{~m}$ ) so that the dose rate would be reduced. Smaller mixing depths are usual!y associated with stable atmospheric conditions which would lead to higher the dose rates at the surface. It should not be concluded from Fig. 6 that a higher dose rate will always be associated with unstable atmospheric conditions. In fact, stable conditions produce higher dose rates farther from the source because the diffusion parameters are much smaller than those determined for unstable conditions.

To verify that AREA EVACUATION predicts the correct wind direction, the model was executed with two wind directions (case 1 and 17). The graphical output of the plume (not shown) indicated that the plume moves in the correct direction downwind of the source.

This evaluation procedure demonstrated that AREA EVACUATION was able to reproduce the theoretically characteristics of a plume. It was found that the plume directions were opposite to wind directions, concentrations increased (decreased) with decreasing (increasing) wind speed, lateral spread of pollutants increased (decreased) with increasing (decreasing) horizontal variation in the winds, and the vertical spread of pollutants increased (decreased) with increasing (decreasing) vertical variation in the winds.

\subsection{PUFF/PLUME}

The results as defined by Eqs. (5) or (6) for a plume using the various cases listed in Tables 1 and 2 are depicted in Figs. 7 - 12. A comparison of the numerical results produced by PUFF/PLUME to the analytic solution as defined by Eqs. (5) or (6) is shown Tables $18-32$. 
Similarly, the results produced as defined by Eqs. (7) or (9) for a puif are depicted in Figs. 13 - 18 and a comparison of PUFF/PLUME to the analytic solution is shown in Tables $33-47$. As in AREA EVACUATION, the results from case 17 are not listed because they were identical to those in case 1, except the wind direction has been altered.

The values of $\sigma_{y}$ and $\sigma_{z}$ for various stability classes (cases 1 and $7-11$ ) as determined by Eqs. (3) and (4) for a plume are depicted in Figs. 7a and 8. These figures are similar to Figs 1 and 2 for AREA EVAUATION because the same equations are employed, although the plume centerline is calculated farther downwind. The values of $\sigma_{y}$ and $\sigma_{z}$ grow significantly larger than AREA EVACUATION so that the plume depth approaches $80 \%$ of the mixing depth approximately $8.0 \mathrm{~km}$ downwind for stability class C. As in AREA EVACUATION the dispersion parameters are very similar to Pasquill-Gifford dispersion diagrams and Brookhaven dispersion diagrams ${ }^{20}$. The values of $\sigma_{y}$ as determined by PUFF/PLUME differed by less than $0.1 \%$ of those predicted by the analytic solution as shown in Fig. $7 \mathrm{~b}$ and are probably due to truncation errors. The values of $\sigma_{2}$ determined by PUFF/PLUME and the analytic solution were identical.

The doses and the concentrations for various types of radionuclides and chemicals (cases 1 - 4) are shown in Fig. 9a and are similar to those in Fig. 3 for AREA EVACUATION. Again, Plutonium-238 has the highest dose because the dose conversion factor is ten times higher than the one for Tritium Oxide. As in AREA EVACUATION, the travel time is relatively small and the dose is not reduced significantly by radioactive decay. The results of PUFF/PLUME are with $0.25 \%$ of the analytic solution as shown in Fig. $9 \mathrm{~b}$.

The dose and concentration also depends indirectly on the depth of the mixing layer, $\mathrm{H}$. In Fig. 10a, the doses for various mixing depths are shown (cases 1 and 5 - 6). For stability class $\mathrm{D}$ (neutral), the dose is identical for a mixing depth of 500 or $1000 \mathrm{~m}$. For stability class A (unstable), the dose is reduced $D 2.0 \mathrm{~km}$ downwind of the source by the same amount as determined by AREA EVAUATION as shown in Fig. 4. PUFF/PLUME uses the same dispersion parameters as in AREA EVAUCATION; therefore, the doses should be nearly identical. Again, the results of PUFF/PLUME are with $0.25 \%$ of the analytic solution as shown in Fig. 10b

The doses for various wind speeds (cases $12-16$ ) are depicted in Fig. 11a. As expected, low wind speeds will produce high ground-level doses and high wind speeds will produce low ground-level doses. The results of PUFF/PLUME are within $0.25 \%$ of the analytic solution except for case 12 (wind speed of $1 \mathrm{~m} \mathrm{~s}^{-1}$ ) where the difference is somewhat larger close to the source (Fig. 11b). This difference is still too small to be considered significant .

The effect of stability on the prediction of doses (cases $7-11$ ) are shown in Fig. 12a. The stability of the atmosphere in this model is slightly different than AREA EVACUATION because of the horizontal resolution of the domains. In AREA EVACUATION, small grid spacing allows for the prediction of dose rates peaks near the release location. PUFF/PLUME is more designed to predict the transport of toxic chemicals or radionuclides farther from the source; therefore, it is not able to resolve peaks doses near the source for most stability classes. The doses are intuitively correct far from the source so that high doses are produced for stable atmospheric conditions and low doses are produced for unstable conditions. The results of PUFF/PLUME are within $0.3 \%$ of the analytic solution except for case 11 (stability class F) where the difference is somewhat larger close to the source (Fig. 12b). This difference is still less than $1 \%$ and is too small to be considered significant. 
To verify that PUFF/PLUME predicts the correct wind direction, the model was executed with two wind directions (case 1 and 17). The graphical output of the plume, (not shown) indicated that the plume moves in the correct direction downwind of the source.

PUFF/PLUME was also executed for a puff using the cases listed in Tables 1 and 2 as input in order to evaluate whether those logic branches agreed with the theoretical solutions described in section 3.1.2.

As shown in Fig. 13a, the values of $\sigma_{y}$ for a puff as calculated by Eqs. (3), (4), (10), and (11) are smaller than those in Fig. 7a close to the source, but they are approximately the same $30 \mathrm{~km}$ downwind of the source. For a puff, the diffusion parameters are originally calculated by Eqs. (10) and (11). As the puff grows with distance, the width grows larger than a plume would for the same meteorological conditions (approximately $15-20 \mathrm{~km}$ downwind for these cases). At this point the code restricts the growth of the puff to be the same as determined by Eqs. (3) and (4) for a plume as described in section 3.1.2. This assumption can also be seen for $\sigma_{2}$ in Fig. 14 when compared to Fig. 8; however, vertical growth occurs very quickly and $\sigma_{z}$ is determined from the plume relationships much closer to the source. The difference between PUFF/PLUME and the analytic solution is again less than $0.25 \%$ as shown in Fig. $13 \mathrm{~b}$.

The doses and the concentrations for various types of radionuclides and chemicals (Fig. 15a), various mixing depths (Fig. 16a), various wind speeds (Fig. 17a), and various stabilities (Fig. 18a) show characteristics that are very similar to those exhibited for a plume calculation. The results are slightly different than the plume cases because the release duration is much shorter and the diffusion parameters are slightly different. The results of PUFF/PLUME are within $0.1 \%$ of the analytic solution most of the time as shown in Figs. 15b, 16b, 17b, and 18b. The puff calculations appear to be slightly more accurate that the calculations made for a plume. Both the plume and puff formulations show the largest difference with the analytic solution for relatively low wind speeds (case 12 , wind speed $1 \mathrm{~m} \mathrm{~s}^{-1}$ ) and stable atmospheric conditions (case 11, stability class F). The graphical output of the plume (not shown) indicated that the puff move $s$ in the correct direction downwind of the source.

This cvaluation frocedure demonstrated that PUFF/PLUME was able to reproduce the theoretically characististics of a plume or puff. Most of the small differences between the numerical calculations : ind the analytic solution can be attributed to truncation errors; however, it appears that PUFF/PIUME may have as much as a $1 \%$ error close to the source for low wind speed and high atmospheric stabilities. This error is still quite small and is acceptable for the purposes of PUFF/PLUME which is to predict doses or concentrations far downwind of the release location. Caution should be used in interpreting results from PUFF/PLUME within $2 \mathrm{~km}$ of the source.

\subsection{DPUF}

The results as defined by Eq. (13) for a puff using the various cases listed in Tables 1 and 2 are depicted in Figs. 19 - 26. A direct comparison of the numerical results produced by 2DPUF compared to the analytic solution as defined by Eq. (13) is shown in Tables $48-61$. As in PUFF/PLUME, the results from case 17 are not listed because they were identical to those in case 1 , except the wind direction has been altered.

The values of $\sigma_{\mathrm{y}}$ and $\sigma_{\mathrm{z}}$ for various stability classes (cases 1 and $7-11$ ) as determined by Eqs. (10) and (11) are depicted in Figs. 19 and 20. Figure 19 is similar to Fig. 13a for PUFF/PLUME except that the $\sigma_{y}$ values computed by 2DPUF are slightly larger $30 \mathrm{~km}$ downwind of the release location. The values of $\sigma_{\mathrm{z}}$ are much larger for stable atmospheric conditions in 2DPUF than in PUFF/PLUME because the puff growth is assumed to be linear 
with distance. For instance, $\sigma_{z}$ is ten times larger in 2DPUF than in PUFF/PLUME for stability class $F 30 \mathrm{~km}$ downwind of the source. The values of $\sigma_{y}$ and $\sigma_{z}$ grow larger than those in PUFF/PLUME because they do not employ Eqs. (3) and (4) when the puff gets sufficiently large. As in PUFF/PLUME the dispersion parameters are very similar to PasquillGifford dispersion diagrams and Brookhaven dispersion diag:ams ${ }^{14}$. The differences in $\sigma_{y}$ and $\sigma_{\mathrm{z}}$ between those calculated by 2DPUF and Eqs. (10) and (11) are negligible.

The doses for various types of radionuclides (cases 1, 3 and 4) are shown in Fig. 21a and are similar to those in Fig. 15 for PUFF/PLUME.. The differences in the magnitudes of the doses with distance are due to the different diffusion parameters and the fact that 2DPUF performs an numerical integration for the dose. The effect of numerical integration produced a larger difference between the numerical results and the analytic solution than for PUFF/PLUME as shown in Fig. 21b. Clearly, the systematic differences between 2DPUF and the analytic solution indicates that some errors due to the numerical integration are introduced into the predictions. 2DPUF agrees with the analytic solution quite well close to the source, but differs by $3 \%$ a few kilometers downwind of the source. As expected the type of release material does not affect the errors produced by 2DPUF.

In Fig. 22a, the doses for various mixed-layer depths are shown (cases 1 and $5-6$ ). For both stability class D (neutral) and A (unstable), the dose is reduced downwind of the source by approximately the same amount as determined by PUFF/PLUME as shown in Fig. 16a. In contrast to PUFF/PLUME, 2DPUF predicts a change in the dose due to different mixed-layer depths for stability class $D$ because the dispersion parameters as computed by Eqs. (1) and (11) are larger than those used by PUFF/PLUME. It can be expected that 2DPUF will be more sensitive to changes in the mixed-layer depth for a wider range of meteorological conditions than PUFF/PLUME. As in Fig. 21b, the results of 2DPUF are with $3 \%$ of the analytic solution for neutral stability cases (Fig. 23b). However, for stability class A, the errors have grown so that 2DPUF and the analytic solution differ by $6 \%$.

The doses for various wind speeds (cases 12 - 16) are depicted in Fig. 23a. 2DPUF produces the same qualitative characteristics that are expected for various wind speeds. Any differences between these results and those produced by PUFF/PLUME are predominantly due to the larger dispersion parameters which tend to decrease the dose when compared to the values produced by PUFF/PLUME. Since neutral atmospheric stability conditions were assumed, the results produced by 2 DPUF are again approximately within $3 \%$ of the analytic solution (Fig. $23 b)$.

The effect of stability on the prediction of doses (cases $7-11$ ) are shown in Fig. 24a. The doses produced by 2 DPUF are very similar to the doses computed by PUFF/PLUME shown in Fig. 18a. Fig. 24b shows the differences between 2DPUF and the analytic solution for these cases. As discussed in section 3.4.3, the time step is a function of $\sigma_{y}$ and the wind speed. Therefore, the time step will grow with increasing atmospheric instability if the wind speed remains constant. A relatively large time step will inevitably produce larger integration errors and this is verified in this figure which indicates that the errors in the model predictions grow with increasing atmospheric instability. These errors do not grow as the puff is transported downwind and range from $1 \%$ for stability class $\mathrm{F}$ to $6 \%$ for stability class $\mathrm{A}$. For stability class $\mathrm{F}$ close to the release location, the predicted dose and the analytic solution differed by as much as $83 \%$. For very small puffs, a extremely small time step must be used to resolve the puff correctly. In this version of 2DPUF, the initial time step is $20 \mathrm{~s}$.

Figure 25 illustrates the effect of the time step on the numerical results produced by 2DPUF. $A$ simulation was performed for case 7 (stability class A) where the time step was reduced by a factor of three. The small time step reduced the difference between the analytic solution and the 
results produced by 2 DPUF from $6 \%$ to $2 \%$. Another simulation was performed for case 11 (stability class F) where the initial time step was reduced from $20 \mathrm{~s}$ to $10 \mathrm{~s}$. The growth rate of the time step was not altered. By reducing the time step in this manner, the difference between the analytic solution and the results produced by 2 DPUF was reduced from $83 \%$ to $20 \% 2 \mathrm{~km}$ downwind of the source. Significantly more accurate results were obtained for the other downwind locations as well. The results of these simulations indicate that the puff can be resolved better if a smaller initial time step is used; however, this would greatly increase the computational time required to run the model and may not be practical for emergency response purposes.

Figure 27 is a summation of the results from the experiments performed with PUFF/PLUME and 2DPUF using all of the cases listed in Tables 1 and 2. Nearly all of the doses computed by F.JFF/PLUME were within a factor of 1.02 (a $2 \%$ difference) of the analytic solution; however, most of the doses computed by 2DPUF were within a factor of 1.06 (a $6 \%$ difference) of the analytic solution.

This evaluation procedure demonstrated that 2DPUF was able to reproduce the theoretically characteristics of a puff. Most of the differences between the numerical calculations and the analytic solution can be attributed to numerical integration errors. The differences between the analytic solution and the numerical results produced by 2DPUF were found to be below $6 \%$ for most cases. Considering the other types of uncertainties involved in the prediction of the dispersion of toxic materials or radionuclides, this error is relatively minor. Caution should be employed when running the model under stable atmospheric conditions close to the source.

\subsection{CONCLUSIONS}

An analytic approach was used in this study to test the logic, coding, and the theoretical limits of the WIND System atmospheric models. A description of the atmospheric models was presented so that the mathematical framework, realism of the physical processes, and the appropriateness of the assumptions could be examined. Then, various meteorological and source term data were defined and used as input for both the atmospheric models and the appropriate analytic solutions. The analytic solutions were solved by programs that were independent of the WIND System atmospheric models. Dose or concentration estimates predicted by the models were then compared to the analytic solutions to evaluate their performance.

The results from AREA EVACUATION and PUFF/PLUME were very nearly identical to the analytic solutions they are based on. The dose or concentration predicted by PUFF/PLUME was always within $1 \%$ of the analytic solution and most of these differences can be attributed to truncation errors associated with processing the data. The largest differences were found to be close to the source during low wind speeds or under stable atmospheric conditions. The evaluation procedure demonstrated that AREA EVACUATION and PUFF/PLUME were able to reproduce the theoretical characteristics of a puff or a plume.

Differences between the dose predicted by 2DPUF and its analytic solution were also of little practical importance although substantially greater than those associated with PUFF/PLUME. This behavior was expected because PUFF/PLUME solves a form of the analytic solution for a single puff, but 2DPUF performs an integration over a period of time for several puffs to obtain the dose. This integration must be solved numerically and will inevitably result in some errors. In this study, the difference between the dose predicted by 2DPUF and the analytic solution was usually less than $6 \%$. The small magnitude of this error can usually be neglected; however, significantly larger differences were found to occur occur close to the source under stable atmospheric conditions when the default time step was used. An experiment that incorporated a smaller time step in 2DPUF was found to improve the accuracy of the dose 
estimate; however, a minor increase of about a minute in the computational time was required. An increase in the execution time may not be acceptable in emergency response situations. Users of the code need to be aware under what conditions the default time step in 2DPUF is valid. In the near future, high-performance computers will allow 2DPUF to reduce the time step and improve its accuracy without increasing the computational time.

The models in this study were executed with relatively simple meteorological conditions and source term input so that a straight-line Gaussian assumption was valid and the analytic solution could be easily compared to the numerical output. The accuracy of the predictions made by the atmospheric models, as with any other model based on the Gaussian approximation, will decrease with increasing complexity in the meteorological conditions. The assumptions outlined in section 3.1 can easily be violated in reality; therefore, the results produced by the models are expected to be farther from the actual values than indicated by the analytic approach used in this study. The accuracy of the predictions will also decrease with uncertainty of the magnitude and duration of the source term. This is the largest uncertainty in dispersion models and will probably be substantially larger than any other uncertainty imposed by the assumptions in the models. As part of the software evaluation being conducted by the ETS, the WIND System atmospheric models have been tested under more complex situations. The results from the atmospheric codes have been compared to observations from tracer experiments ${ }^{3,5}$ and to the output from other dispersion models ${ }^{6}$.

The WIND System atmospheric rnodels are similar to many other dispersion codes used by the DOE, NRC, and EPA, except that they have been adapted specifically for SRS purposes. If the quality of the source term and meteorological data is high, relatively accurate and timely forecasts for emergency response situations can be made by the WIND System atmospheric models. Users of the WIND System should be aware of the potential errors associated with dispersion modeling so that the results of the atmospheric models can be interpreted correctly.

\section{REFERENCES}

1 Hunter, C. H., Weather Information and Display (WIND) System User's Manual. WSRC-TM-90-14, Savannah River Site, Aiken, SC (1990).

2. Weber. A. H., "The MATS (Mesoscale Atmospheric Transport Studies) Experiments", Proceedings of the DOE/AMS air pollution model evaluation workshop, Kiawah Island, SC, October 23-26, pp 1-25, 1984, Vol. 1. DP-1701-1. DuPont de Nemours and Company, Savannah River Laboratory, Aiken, SC (1984).

3. Addis, R. P., An Evaluation of SRL Emergency Response Codes using MATS Data. DPST-850715, DuPont de Nemours and Company, Savannah River Laboratory, Aiken, SC (1985).

4. Fast, J. D., and R. P. Addis. Evaluation Protocol for the WIND System Atmospheric Models. WSRC-RP-91-426, Savannah River Site, Aiken, SC (1991).

5. Fast, J. D., and S. Berman. A Comparison of the WIND System Atmospheric Models and MATS Data. WSRC-RP-91-1209, Savannah River Site, Aiken, SC (1991).

6. Fast, J. D. A Comparison of the WIND System Atmospheric Models and RASCAL. WSRC-RP-91-894, Savannah River Site, Aiken, SC (1991).

7. Fox, D. G., "Judging Air Quality Model Performance", Bulletin of the American Meteorological Society, 62, pp 599-609 (1980). 
8. Garrett, A. J., and C. E. Murphy Jr., A Puff-Plume Atmospheric Deposition Model for use at SRP in Emergency Response Situations. DP-1595. DuPont de Nemours and Company, Savannah River Laboratory, Aiken, SC (1981).

9. Addis, R. P, and L. O'Steen, 2DPUF, A Sequential Gaussian Puff Model. WSRCRP-90-1208. Savannah River Site, Aiken, SC (1990).

10. Pielke, R. A., Mesoscale Meteorological Modeling. 612 p, Academic Press, New York (1984).

11. International Commission on Radiological Protection, Limits for Intake of Radionuclides by Workers, Publication 30, Part 1, Permagon Press (1979).

12. Pasquill, F., Atmospheric Dispersion Parameters in Gaussian Plume Modeling Part II. EPA-600/4-76-030b. U. S. Environmental Protection Agency, Office of Research and Development, Environmental Sciences Research Laboratory, Research Triangle Park, NC 27711 (1976).

13. Monteith, J. L., Vegetation and the Atmosphere. Academic Press, New York (1975).

14. Pasquill, F. Atmospheric Diffusion. 222 p, John Wiley, New York, (1974).

15. Meteorological Monitoring Procedures. L15.3, Savannah River Site, Aiken, SC (1991).

16. Pendergast, M. M., Real Time Quality Control of Meteorological Data Used in SRP's Emergency Response System. DP-1551. DuPont de Nemours and Company, Savannah River Laboratory, Aiken, SC (1980).

17. Gifford, F. A., W. M. Porch, and W. E. Clements, A Guide to the Applicability of DOE Atmospheric Modeling Resources to Plutonium Emergency Management Studies. draft report, Los Alamos National Laboratory, Los Alamos, NM (1990).

18. Hunter, C. H., A Climatological Description of the Savannah River Site. WSRC-RP89-313, Savannah River Site, Aiken, SC (1991).

19. Survey of DOE Emergency Management Atmospheric Modeling Resources. Subcommittee on Dose Assessment, U. S. Department of Energy, (1990).

20. Panofsky, H.A, and J. A. Dutton, Atmospheric Turbulence. 397 p, John Wiley and Sons, New York (1984). 


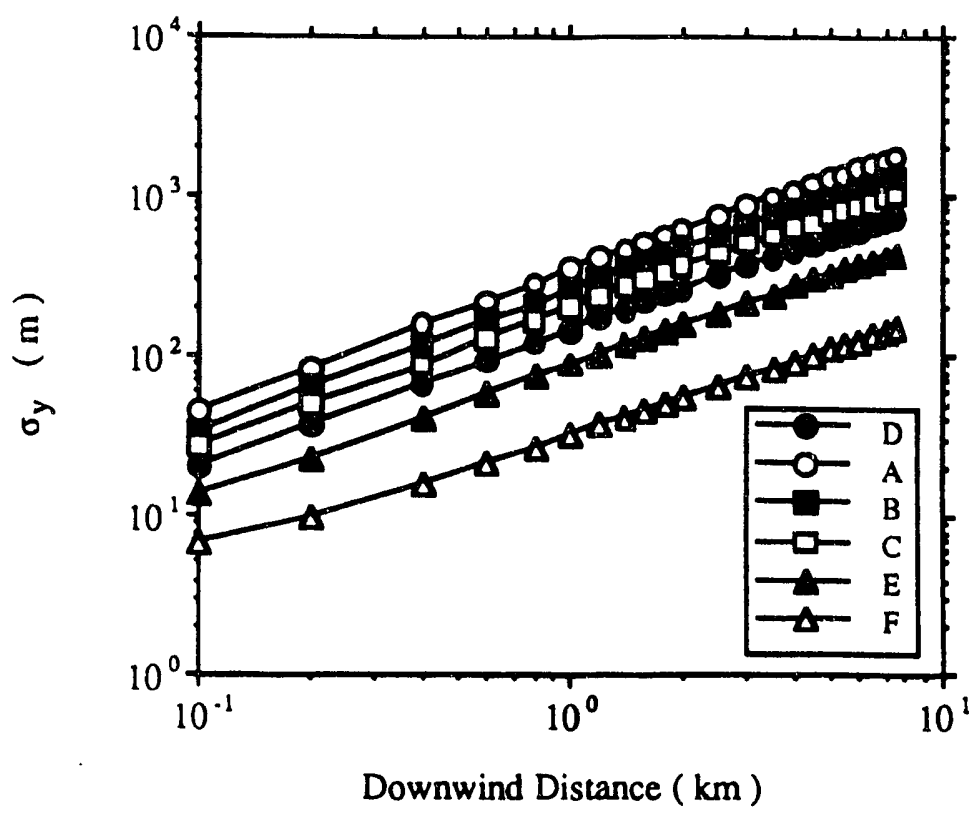

Figure 1. Horizontal standard deviation of the plume width, $\sigma_{y}$, calculated by AREA EVACUATION for various stability classes (cases 1, 7 , 8, 9, 10, 11 from Table 1)

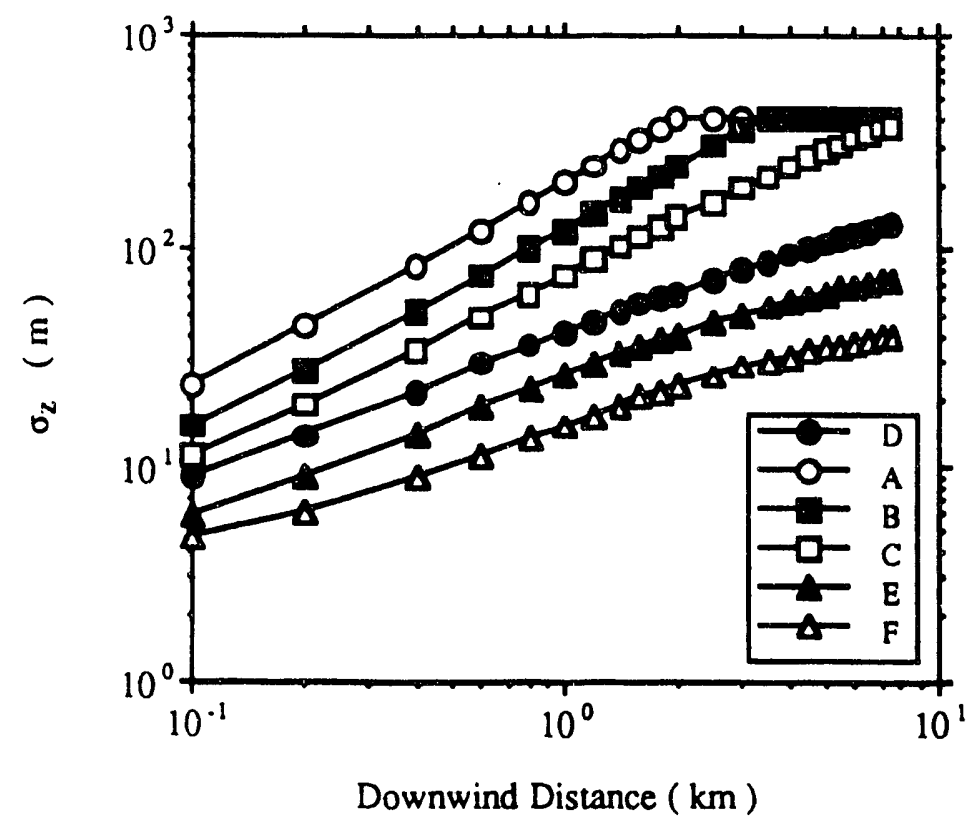

Figure 2. Same as Fig. 1, except for vertical standard deviation of the plume width, $\sigma_{z}$ 


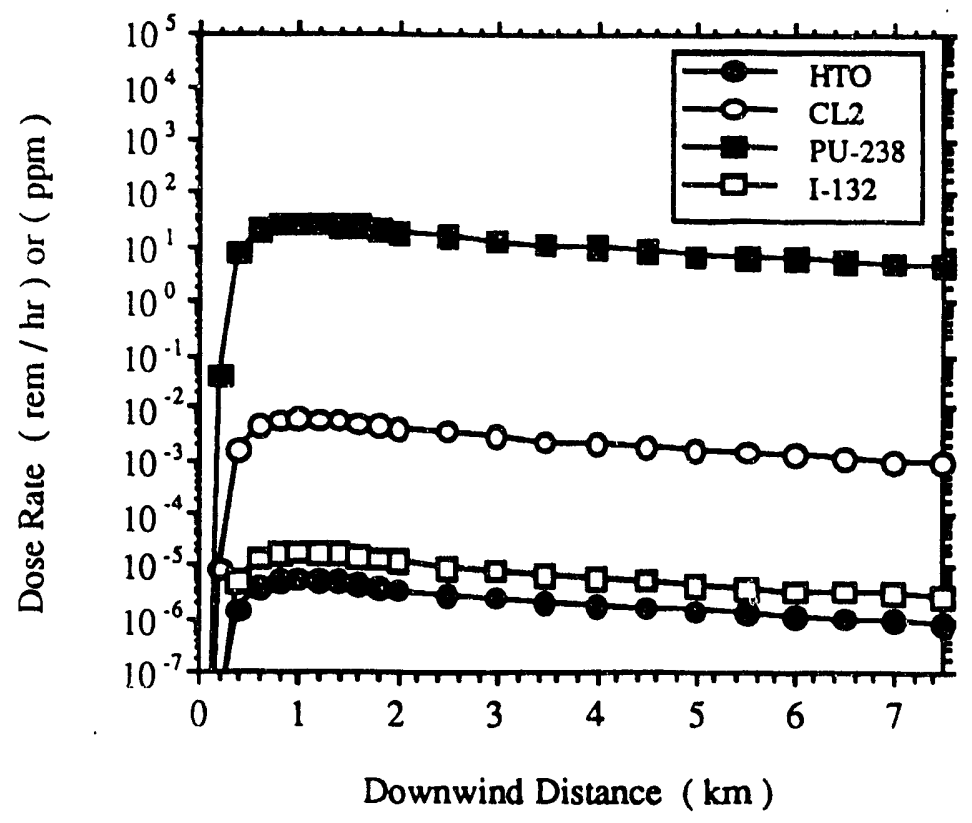

Figure 3. Dose rate or concentration calculated by AREA EVACUATION for various radionuclides and chemicals (cases 1, 2, 3, 4 from Table 1)

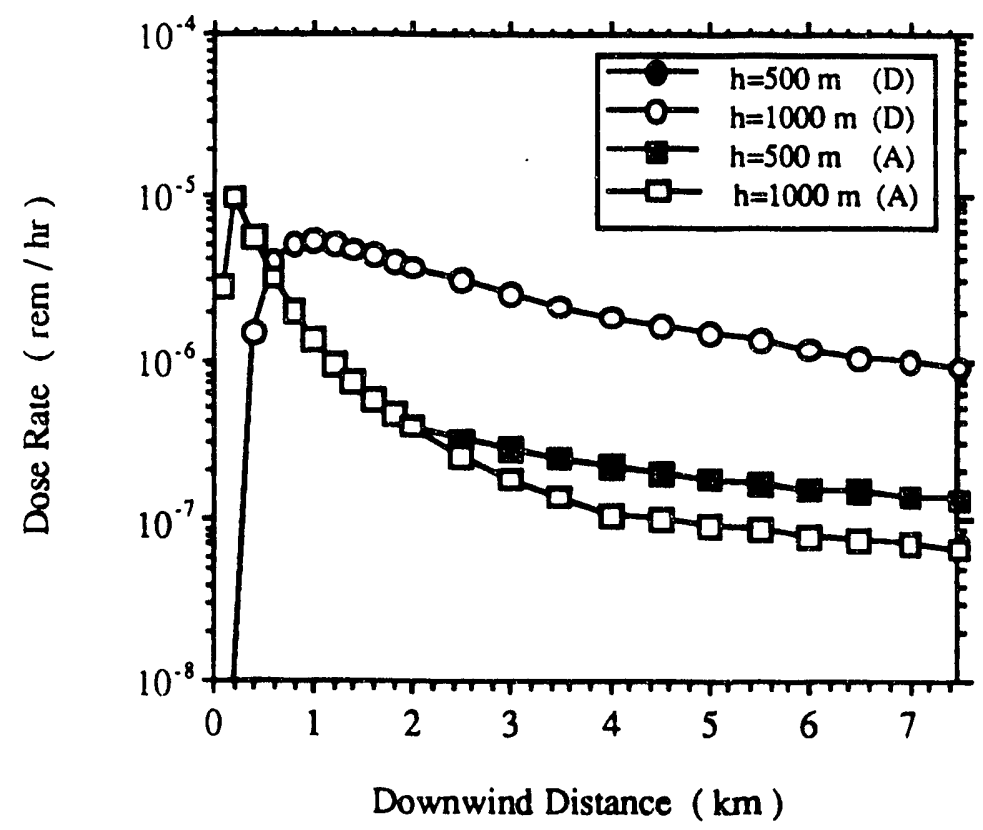

Figure 4. Dose rate calculated by AREA EVACUATION for various mixing depths (cases 1, 5, 6, 7 from Table 1) 


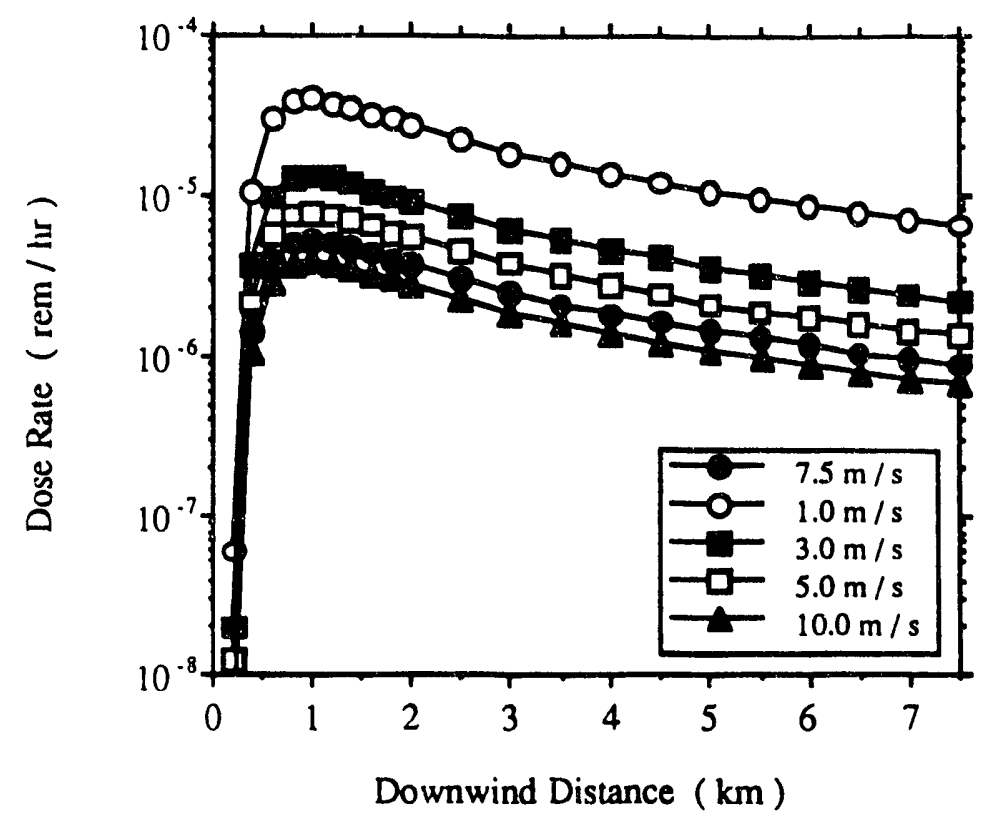

Figure 5. Dose rate calculated by AREA EVACUATION for various wind speeds (cases 1, 12, 13, 14, 15 from Table 1)

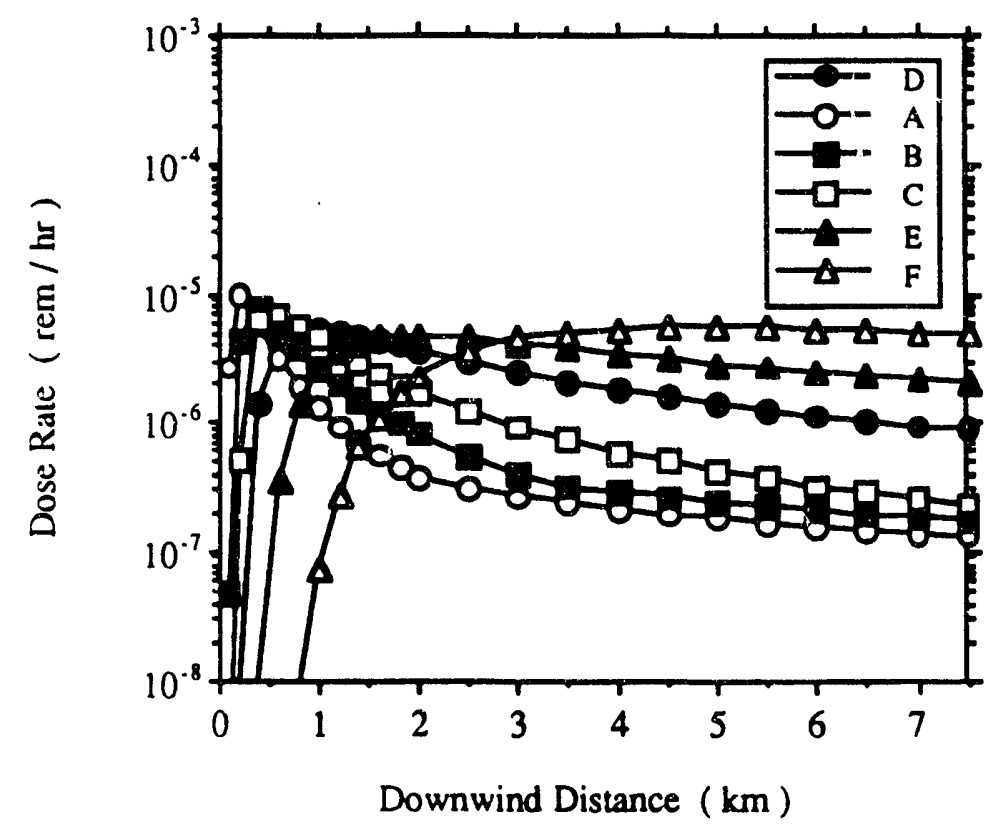

Figure 6. Dose rate calculated by AREA EVACUATION for various stability classes (cases 1, 7, 8, 9, 10, 11 from Table 1) 


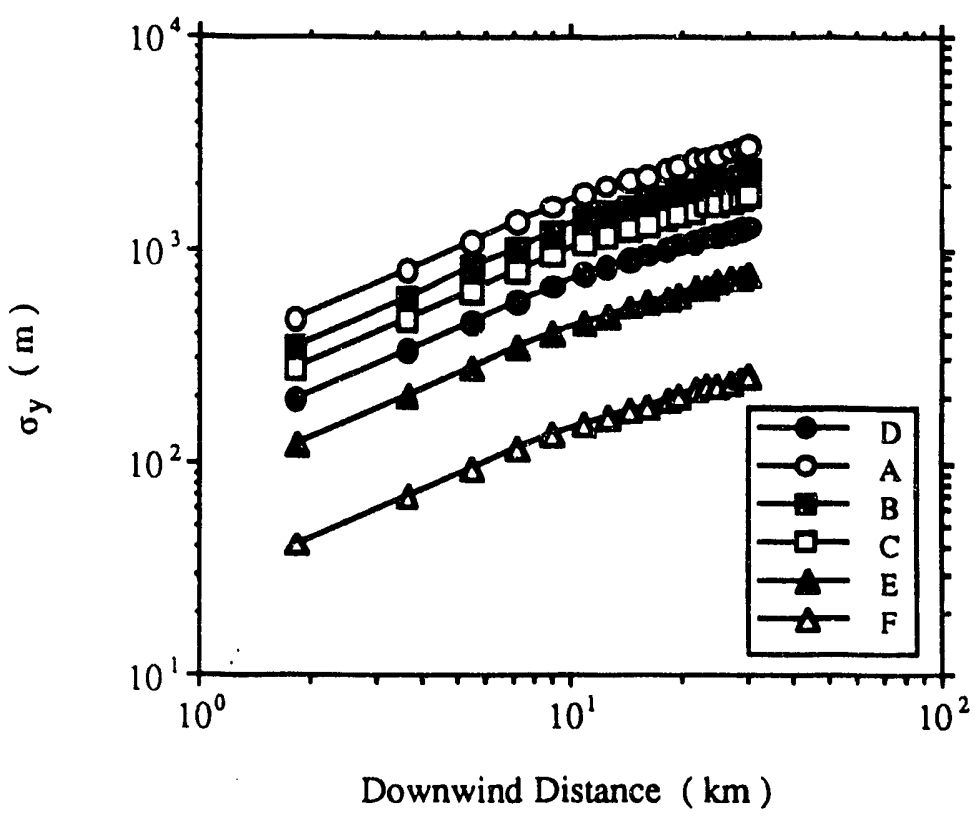

(a)

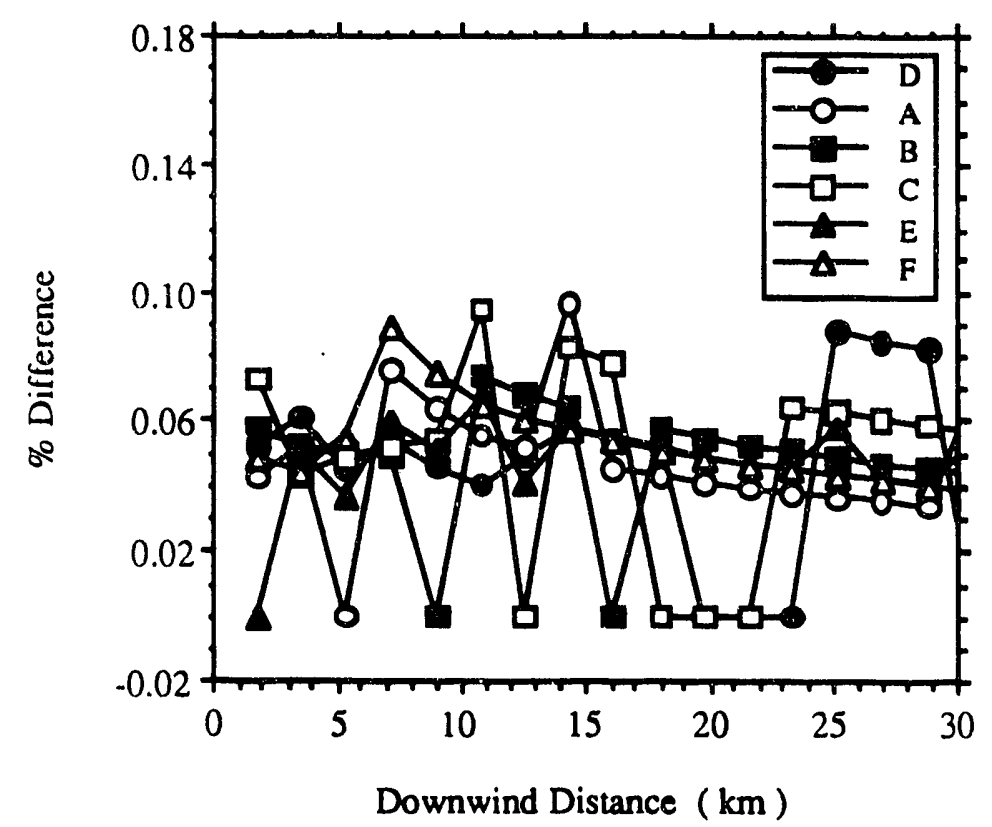

(b)

Figure 7. (a) Horizontal standard deviation of the plume width, $\sigma_{\mathbf{y}}$, calculated by the analytic solution and (b) percent error of the numerical solution calculated by PUFF/PLUME for various stability classes assuming a continuous release (cases 1, 7, 8, 9, 10, 11 from Table 1) 


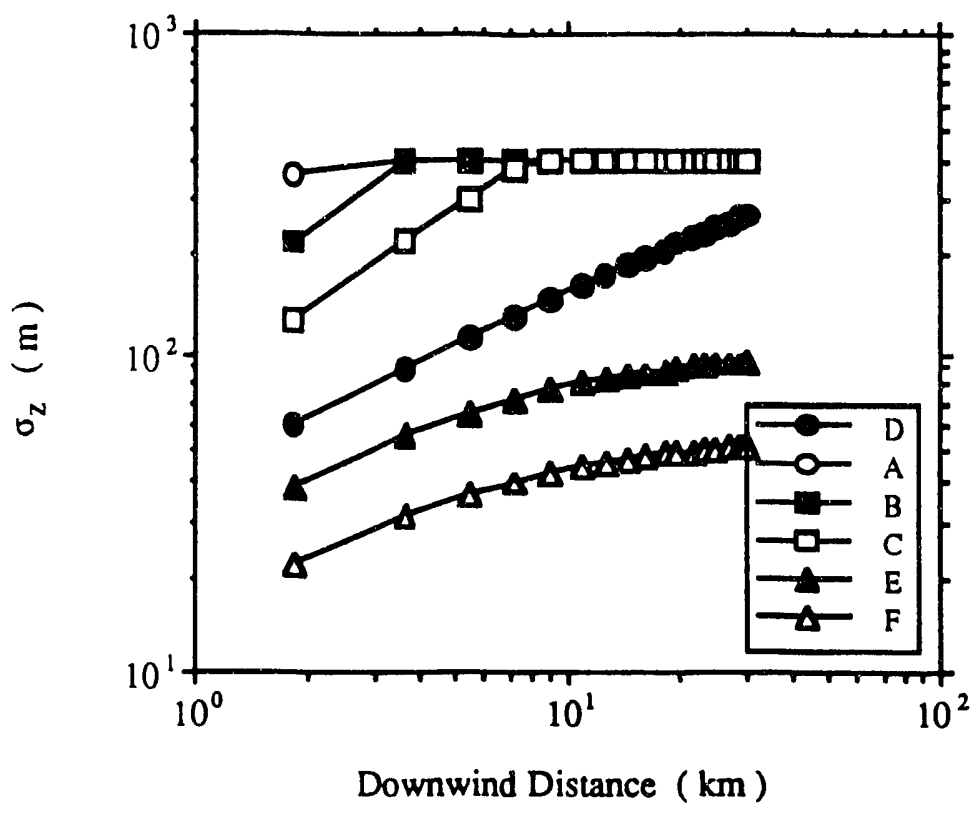

Figure 8. Same as Fig. 7a, except for vertical standard deviation of the plume width, $\sigma_{\mathbf{z}}$ 


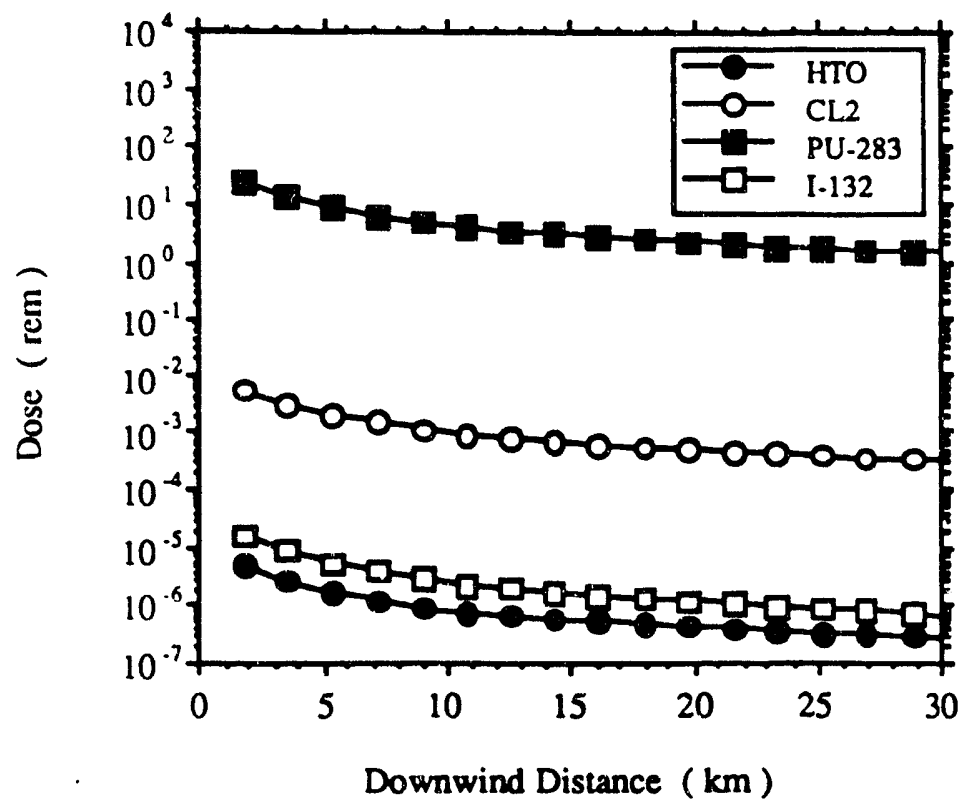

(a)

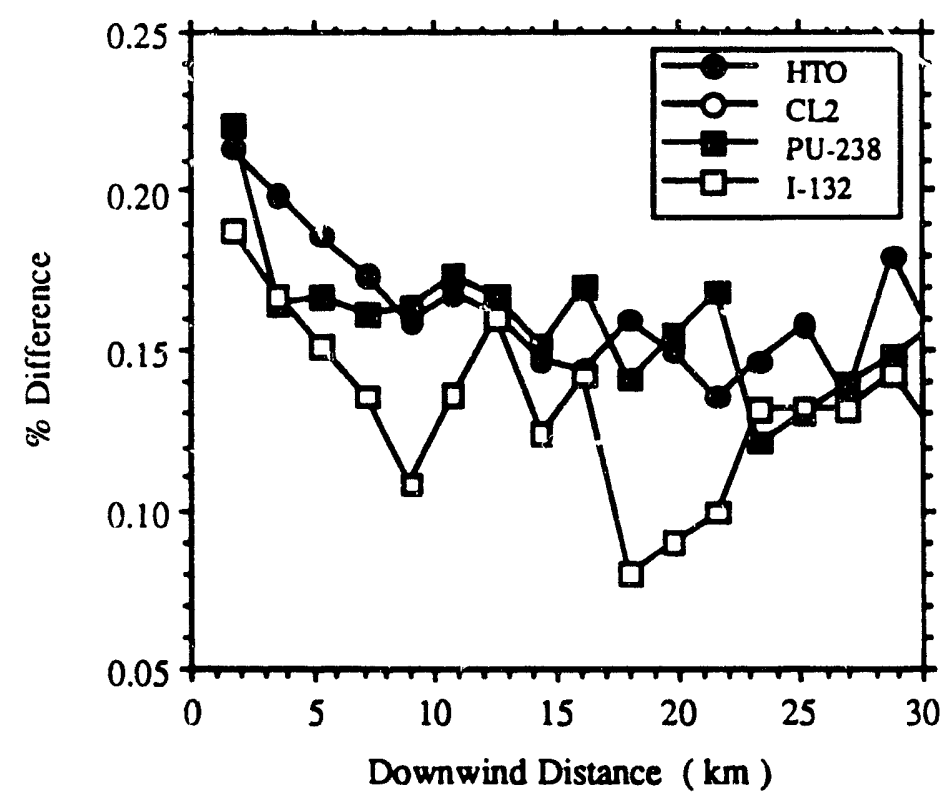

(b)

Figure 9. (a) Dose or concentration calculated by the analytic solution and (b) percent error of the numerical solution calculated by PUFF/PLUME for various radionuclides and chemicals assuming a continuous release (cases $1,2,3,4$ from Table 1) 


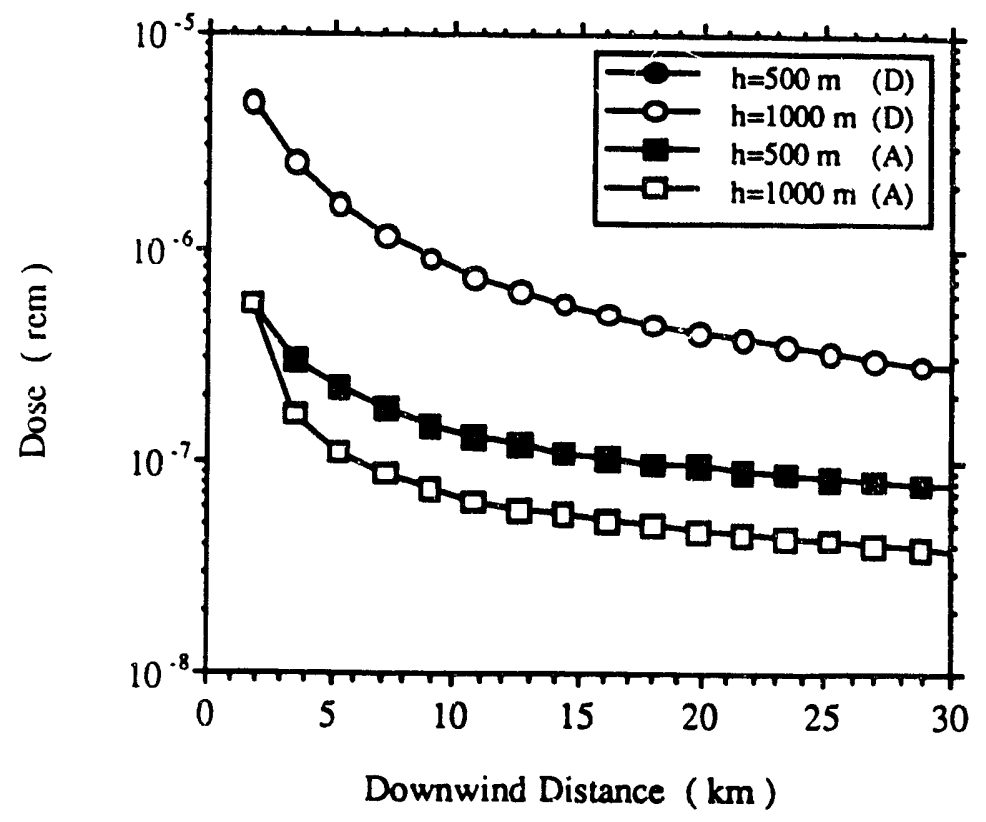

(a)

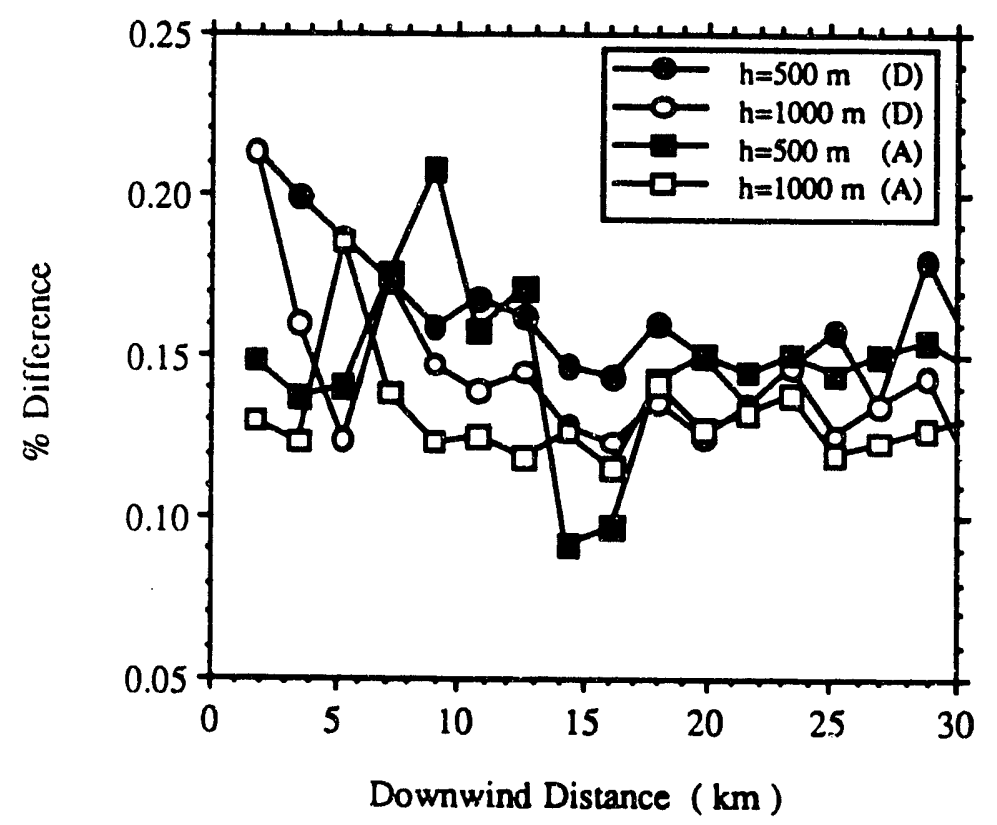

(b)

Figure 10. (a) Dose calculated by the analytic solution and (b) percent error of the numerical solution calculated by PUFF/PLUME for various mixing depths assuming a continuous release (cases 1, 5, 6, 7 from Table 1) 


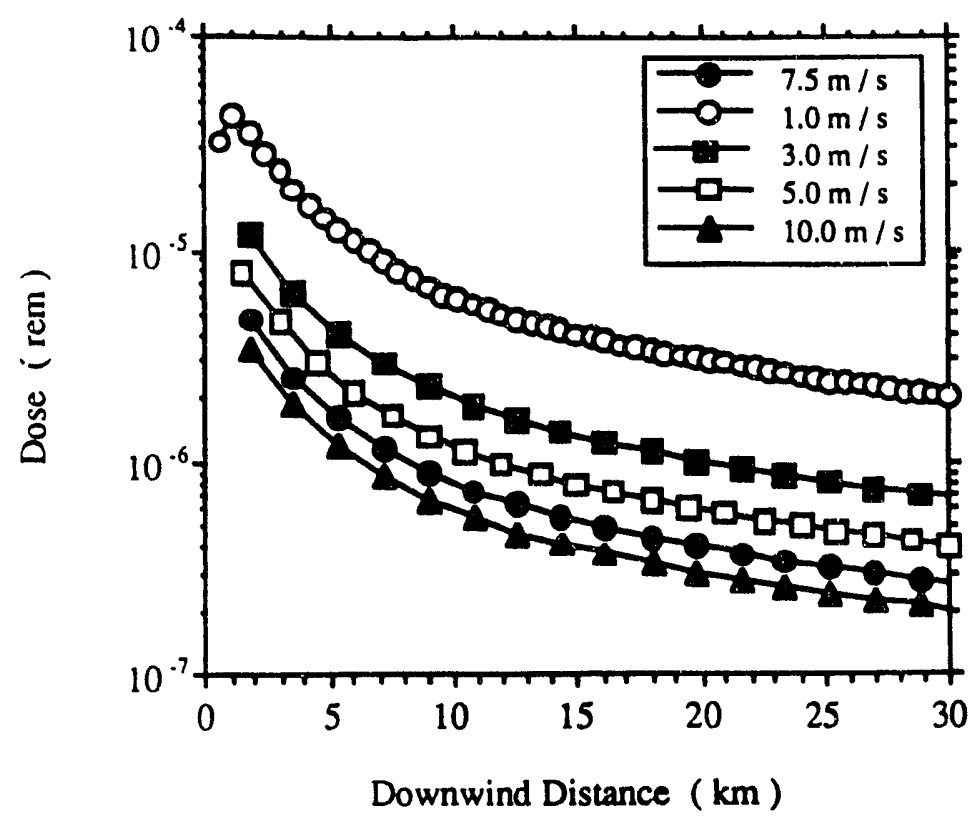

(a)

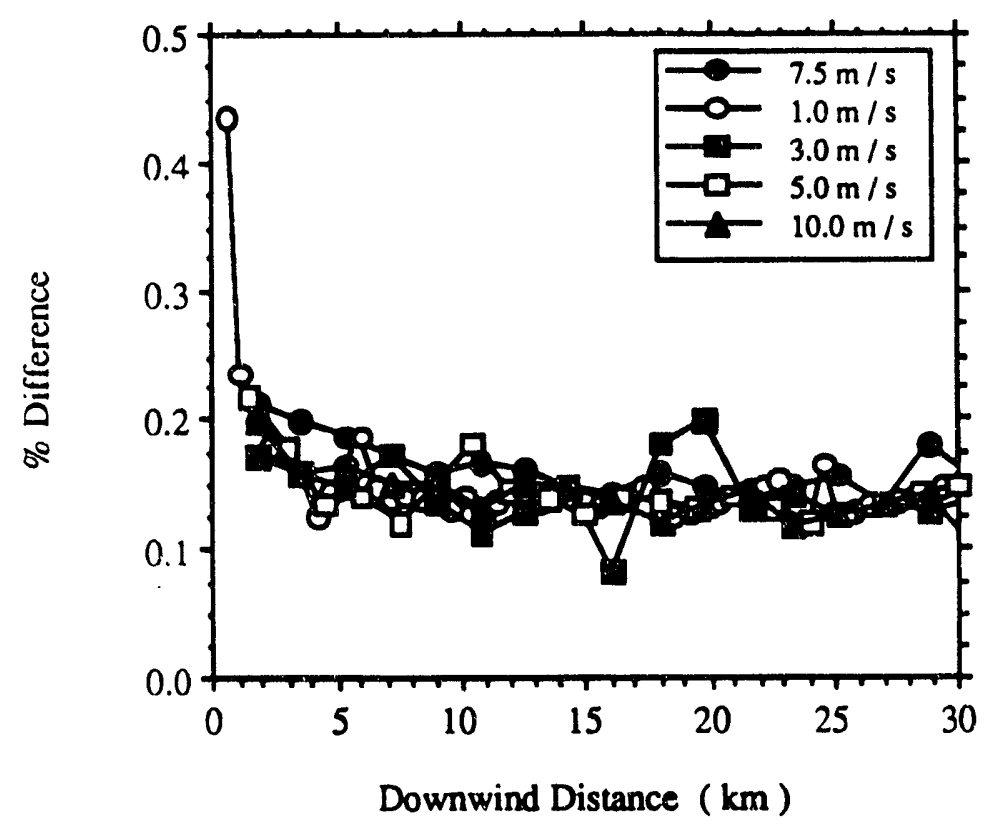

(b)

Figure 11. (a) Dose calculated by the analytic solution and (b) percent error of the numerical solution calculated by PUFF/PLUME for various wind speeds assuming a continuous release (cases 1, 12, 13, 14, 15 from Table 1) 


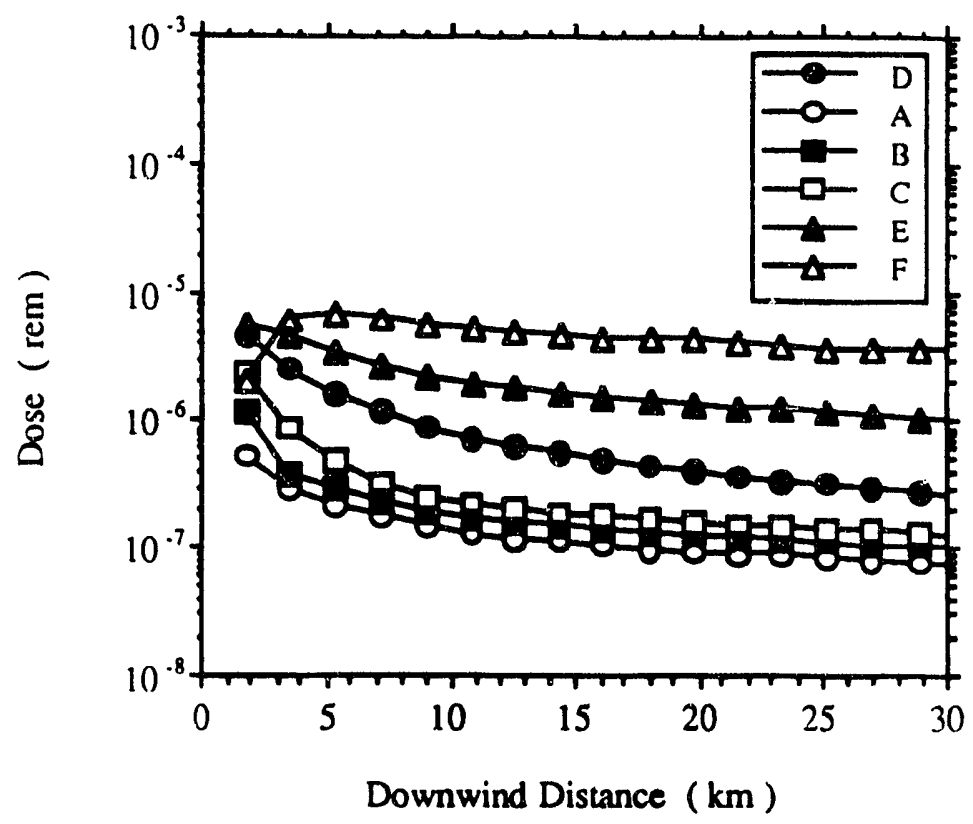

(a)

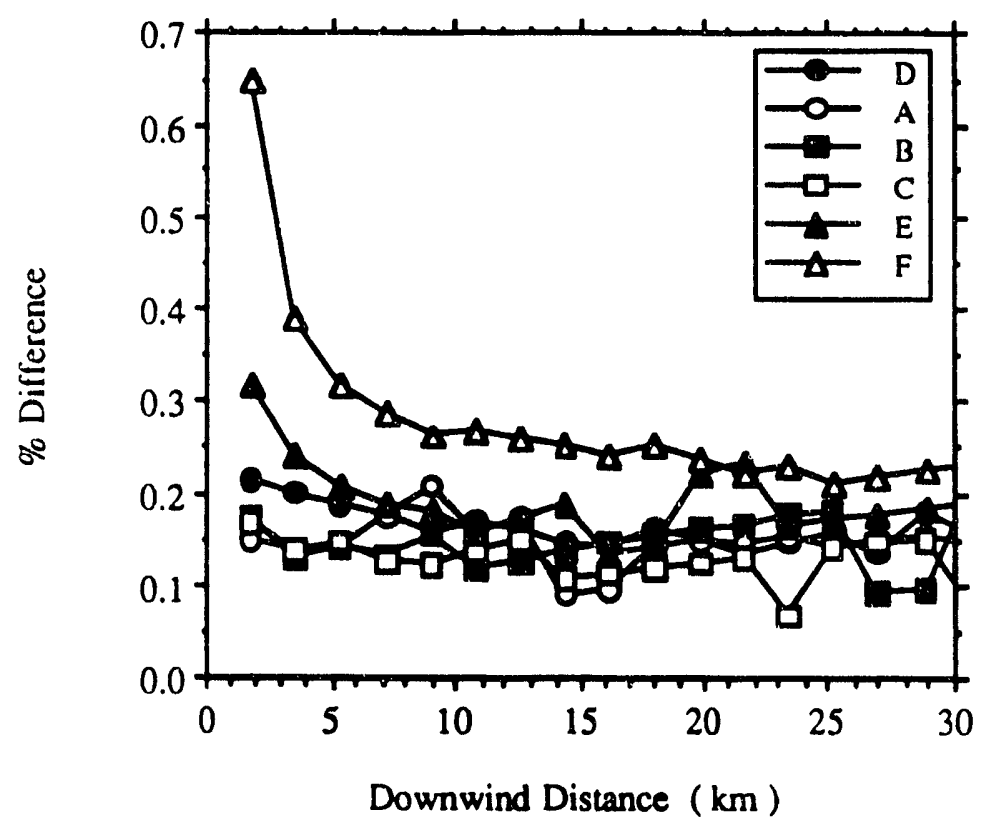

(b)

Figure 12. (a) Dose calculated by the analytic solution and (b) percent error of the numerical solution calculated by PUFF/PLUME (b) for various stability classes assuming a continuous release (cases 1 , $7,8,9,10,11$ from Table 1). 


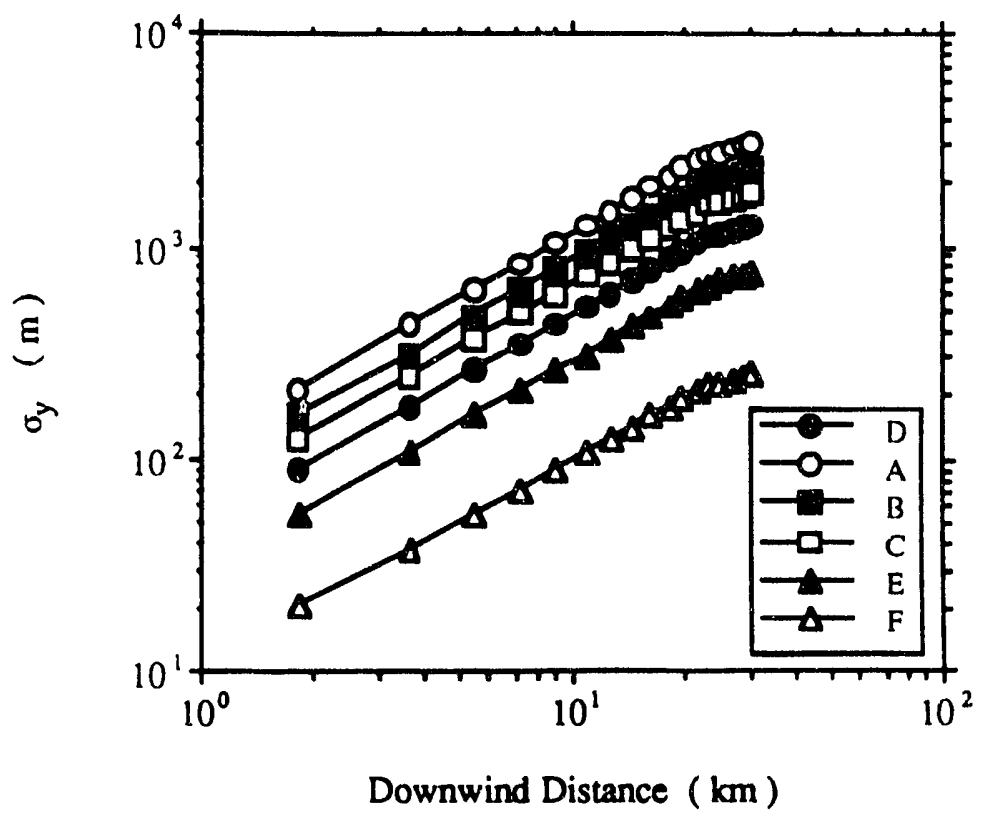

( a )

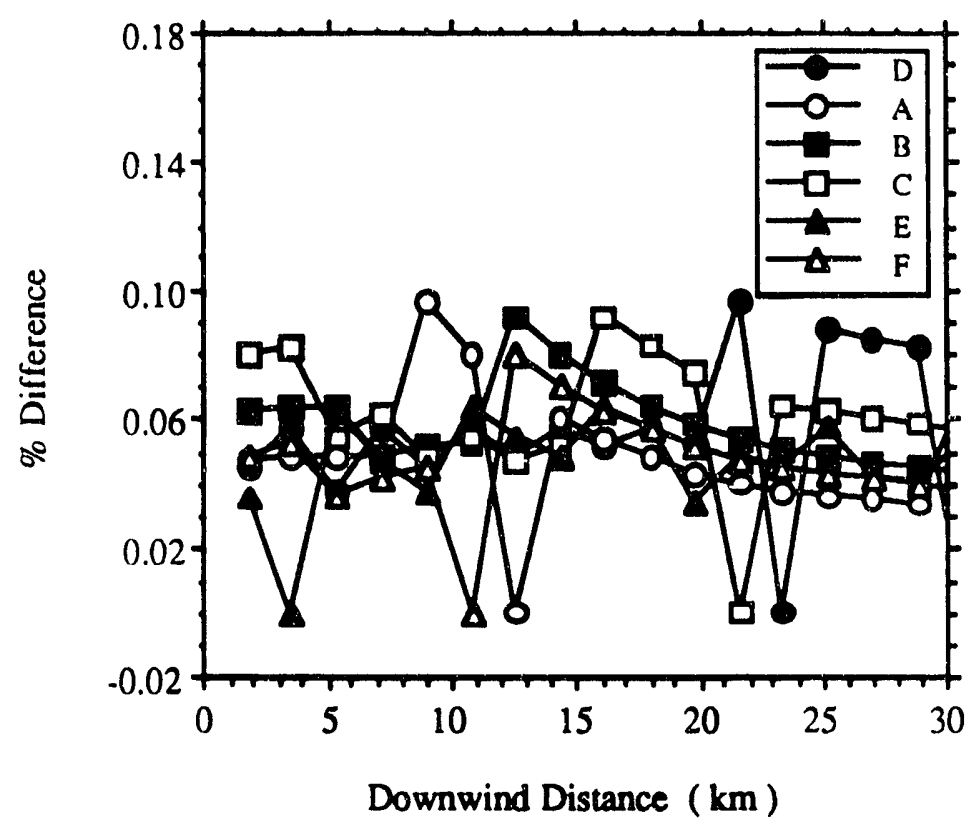

(b)

Figure 13. (a) Horizontal standard deviation of the plume width, $\sigma_{y}$, calculated by the analytic solution and (b) percent error of the numerical solution calculated by PUFF/PLUME for various stability classes assuming an instantaneous release (cases $1,7,8$, 9, 10, 11 from Table 1) 


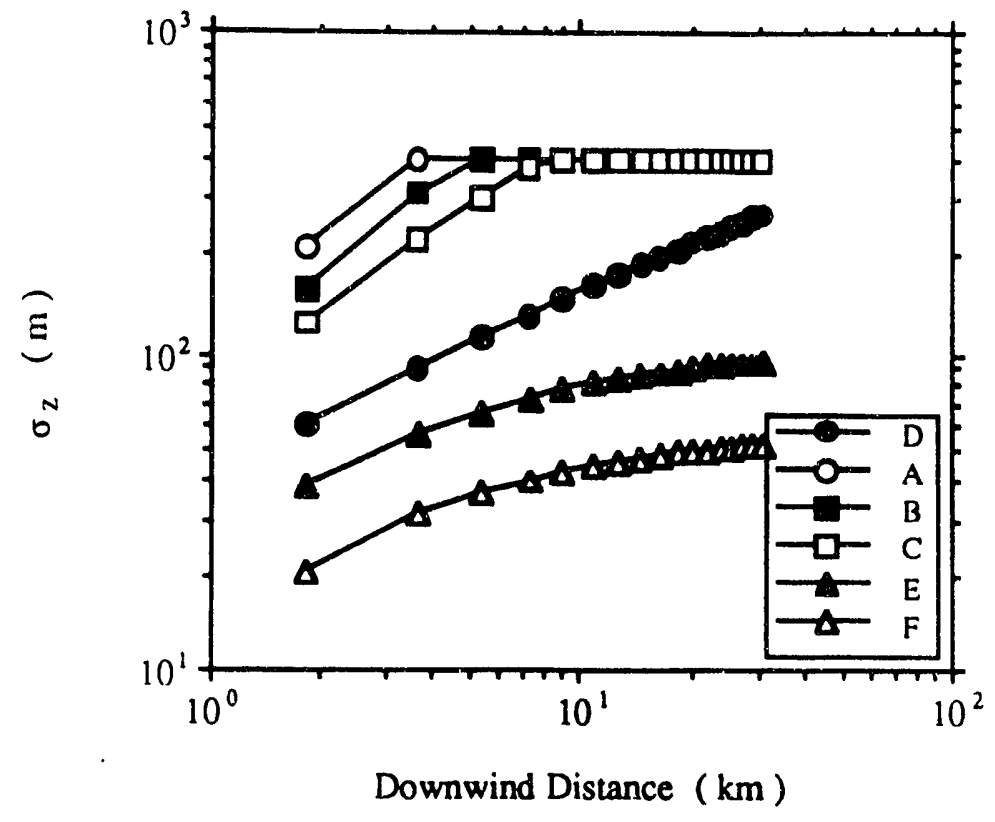

Figure 14. Same as Fig. 13, except for vertical standard deviation of the plume width, $\sigma_{z}$ 


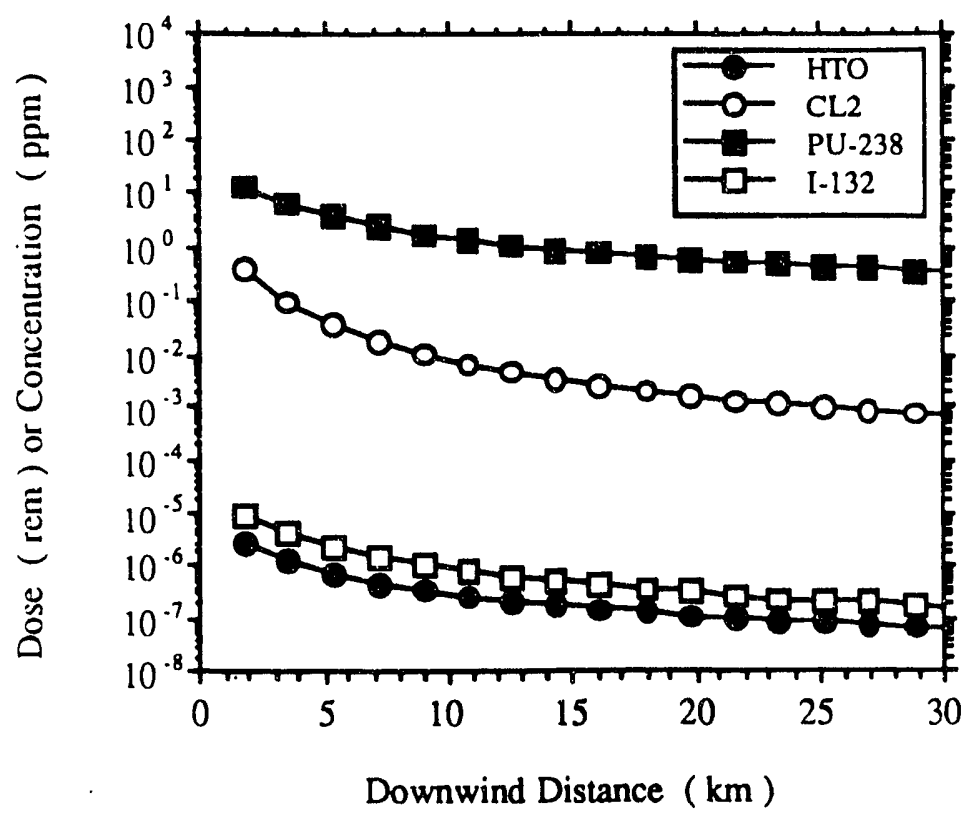

(a)

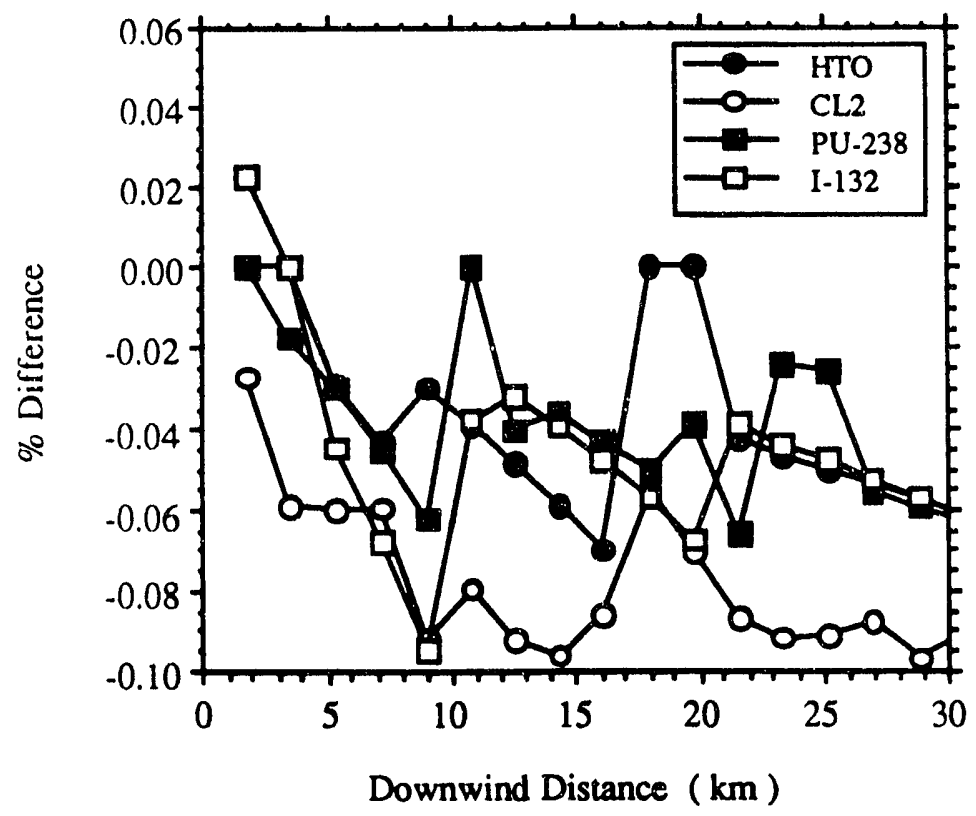

(b)

Figure 15. (a) Dose or concentration calculated by the analytic solution and (b) percent error of the numerical solution calculated by PUFF/PLUME for various radionuclides and chemicals assuming an instantaneous release (cases $1,2,3,4$ from Table 1) 


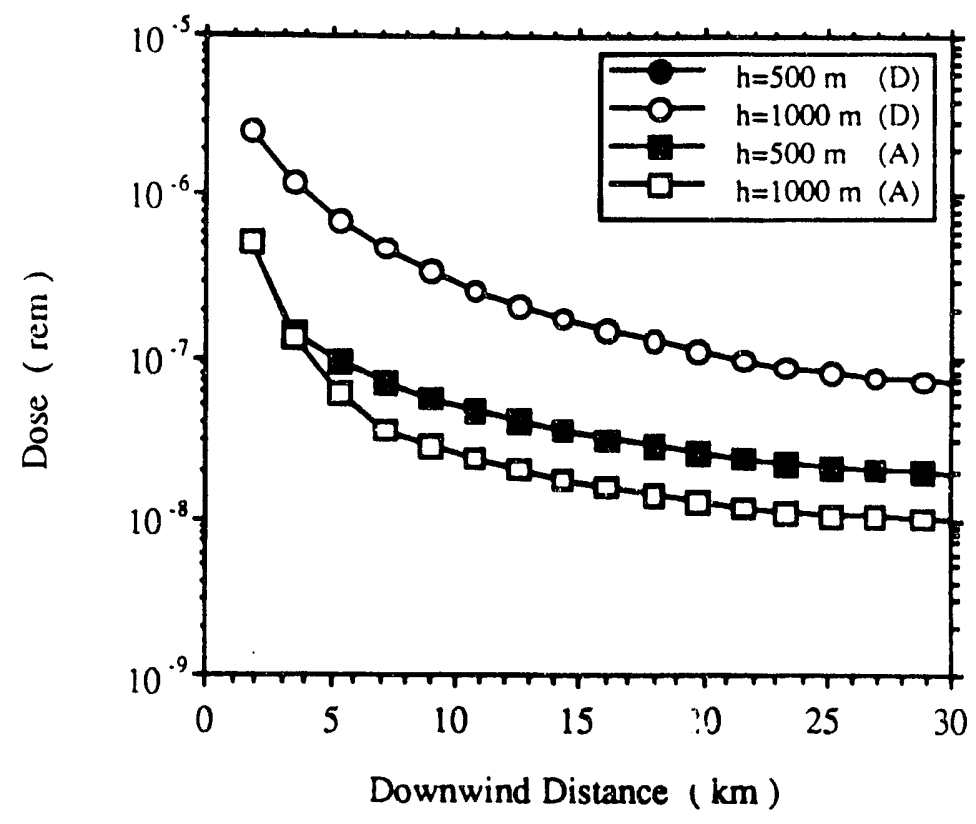

(a)

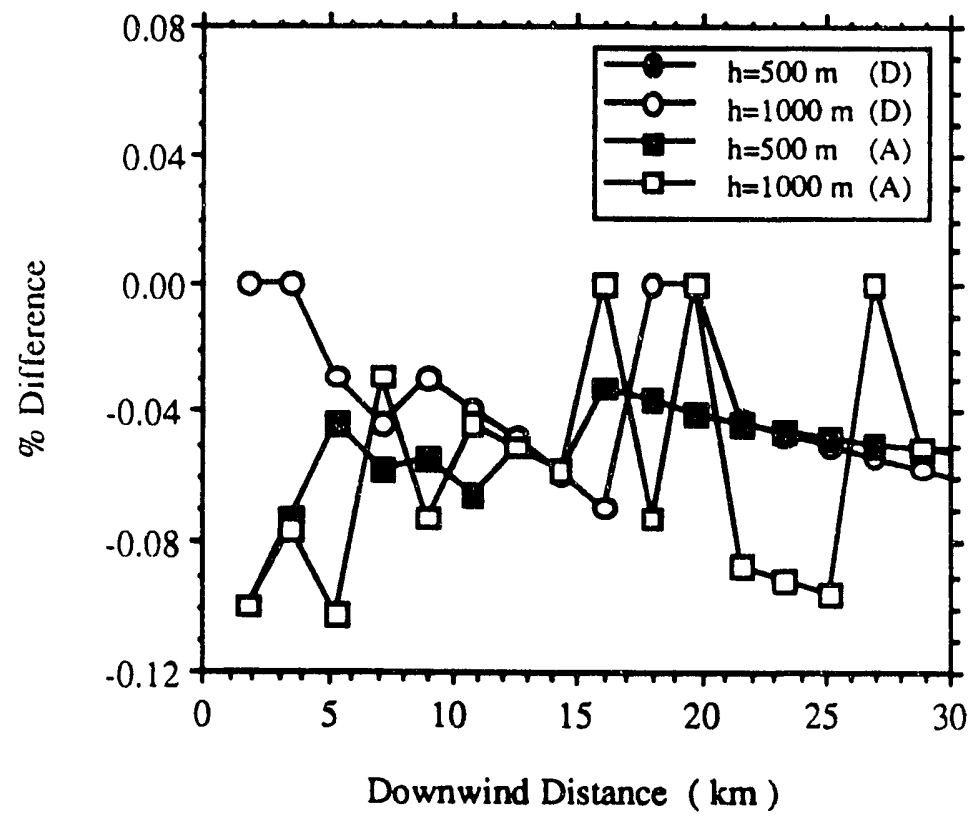

(b)

Figure 16. (a) Dose calculated by the analytic solution and (b) percent error of the numerical solution calculated by PUFF/PLUME for various mixing depths assuming an instantaneous release (cases $1,5,6,7$ from Table 1) 


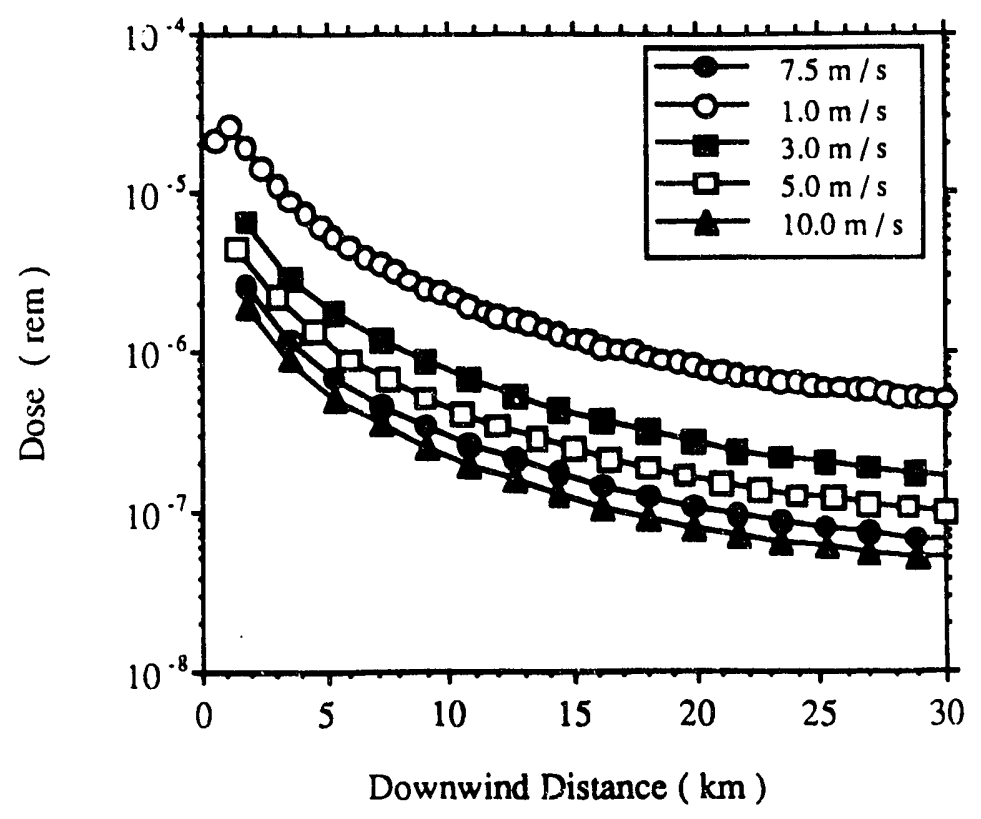

(a)

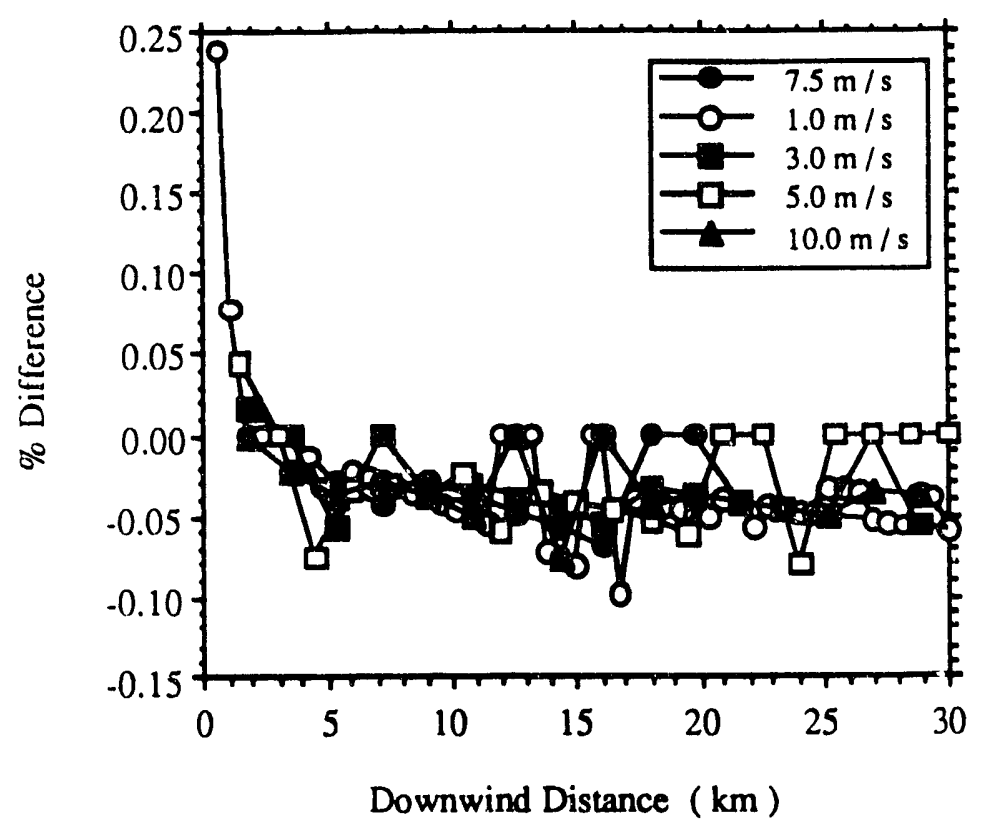

(b)

Figure 17. (a) Dose calculated by the analytic solution and (b) percent error of the numerical solution calculated by PUFF/PLUME for various wind speeds assuming an instantaneous release (cases 1, 12, 13, 14, 15 from Table 1) 


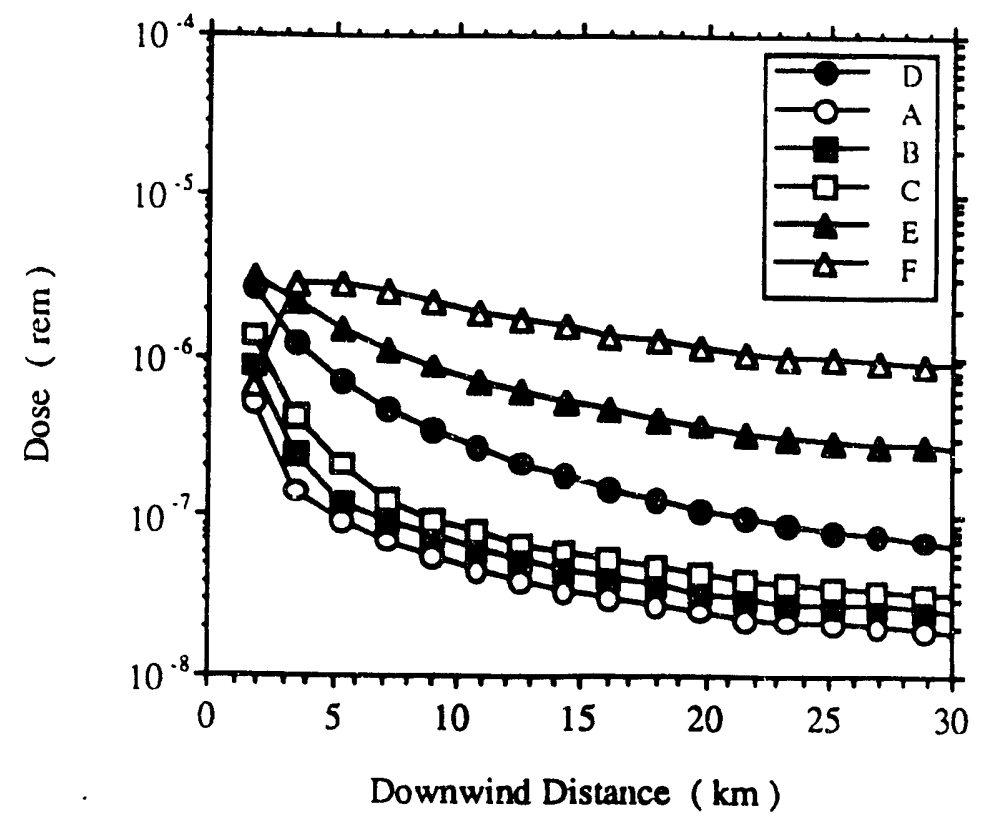

(a)

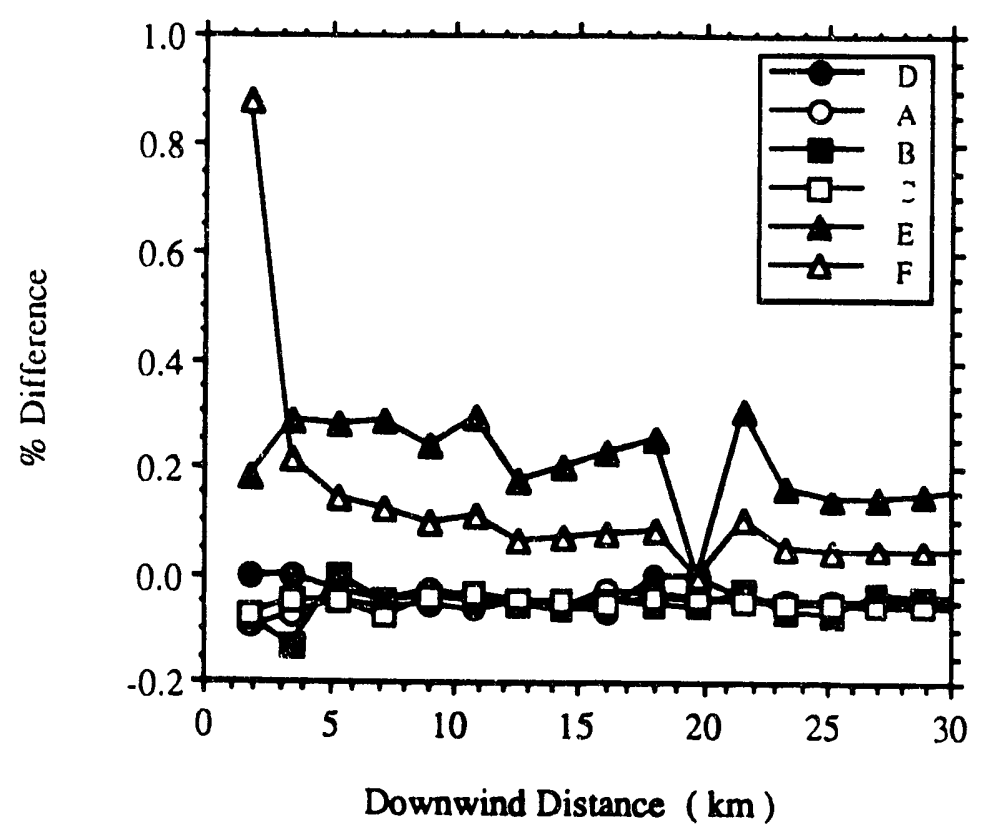

(b)

Figure 18. (a) Dose calculated by the analytic solution and (b) percent error of the numerical solution calculated by PUFF/PLUME for various stability classes assuming an instantaneous release (cases $1,7,8$, 9, 10, 11 from Table 1) 


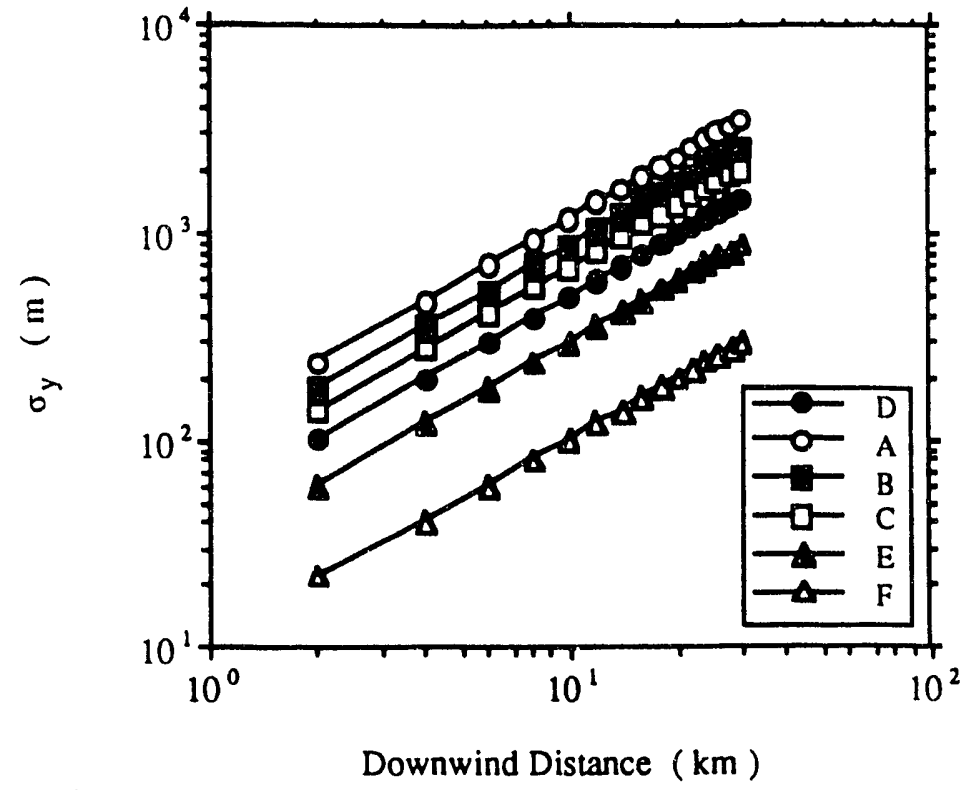

Figure 19. Horizontal standard deviation of the plume width, $\sigma_{y}$, calculated by the analytic solution and 2DPUF for various stability classes assuming an instantaneous release (cases $1,7,8,9,10,11$ from Table 1)

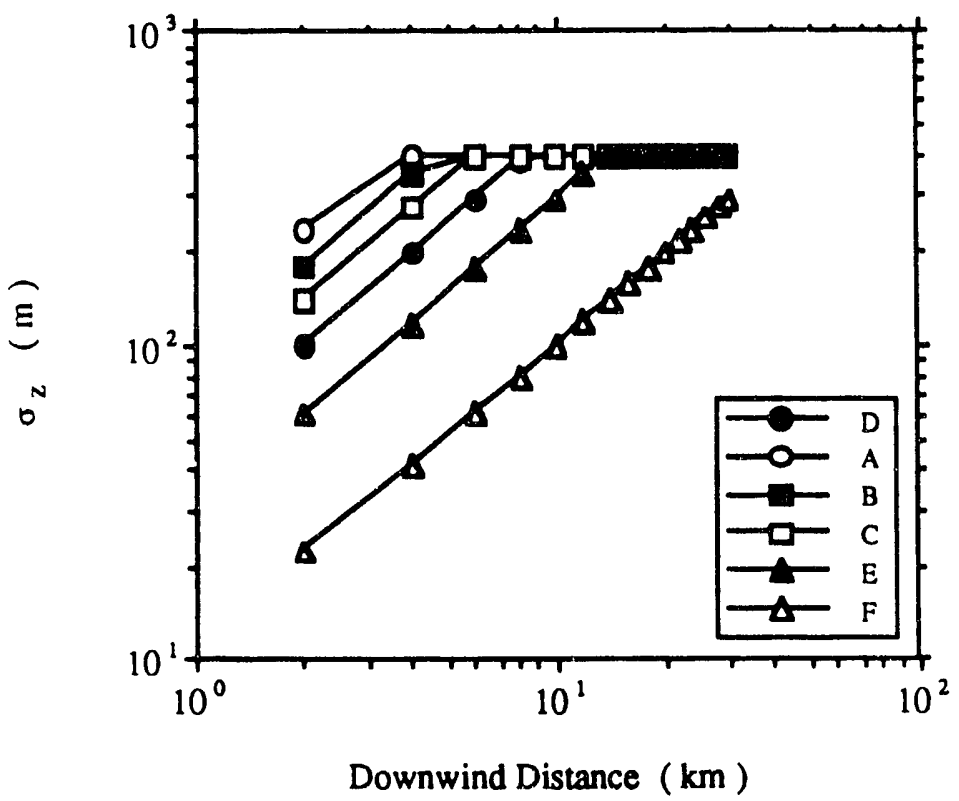

Figure 20. Same as Fig. 19, except for the vertical standard deviation of the plume width, $\sigma_{z}$ 


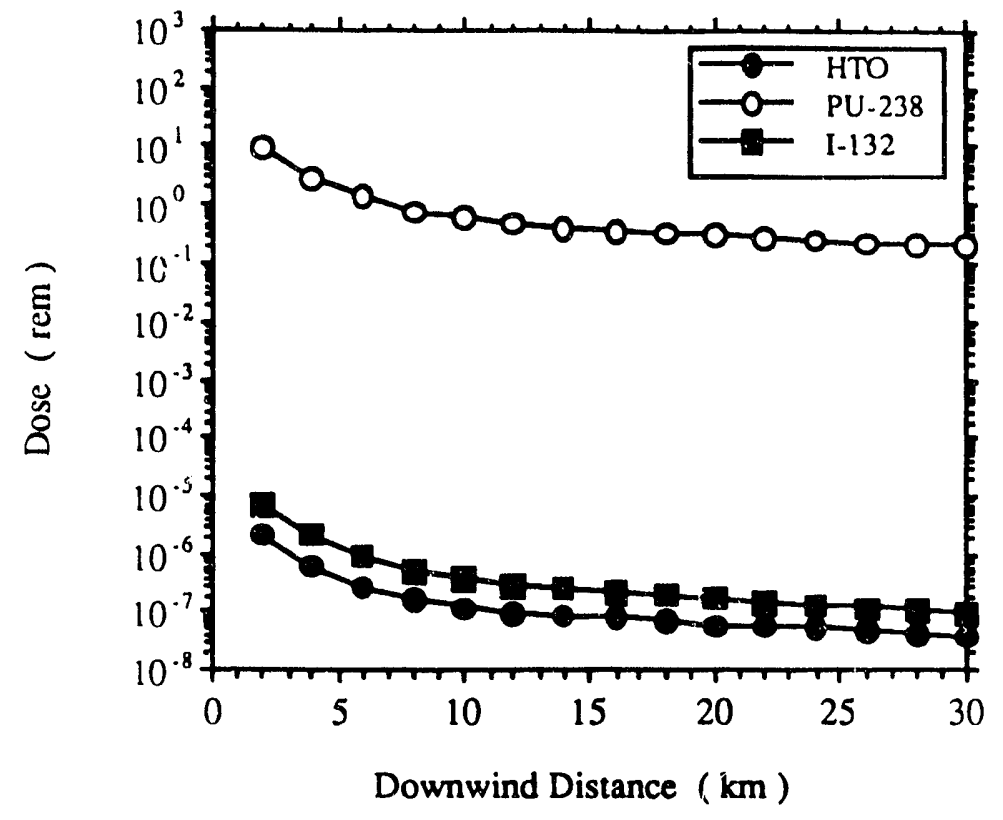

(a)

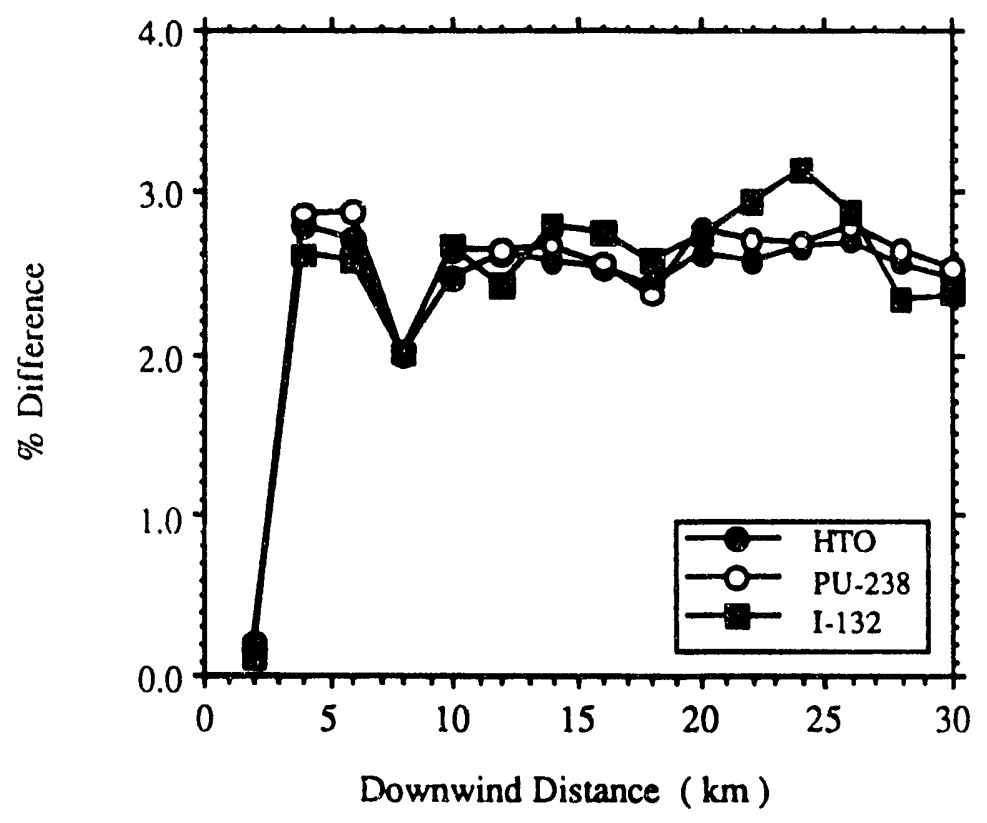

(b)

Figure 21. (a) Dose calculated by the analytic solution and (b) percent error of the numerical solution calculated by $2 D P U F$ for various radionuclides assuming an instantaneous release (cases $1,3,4$ from Table 1) 


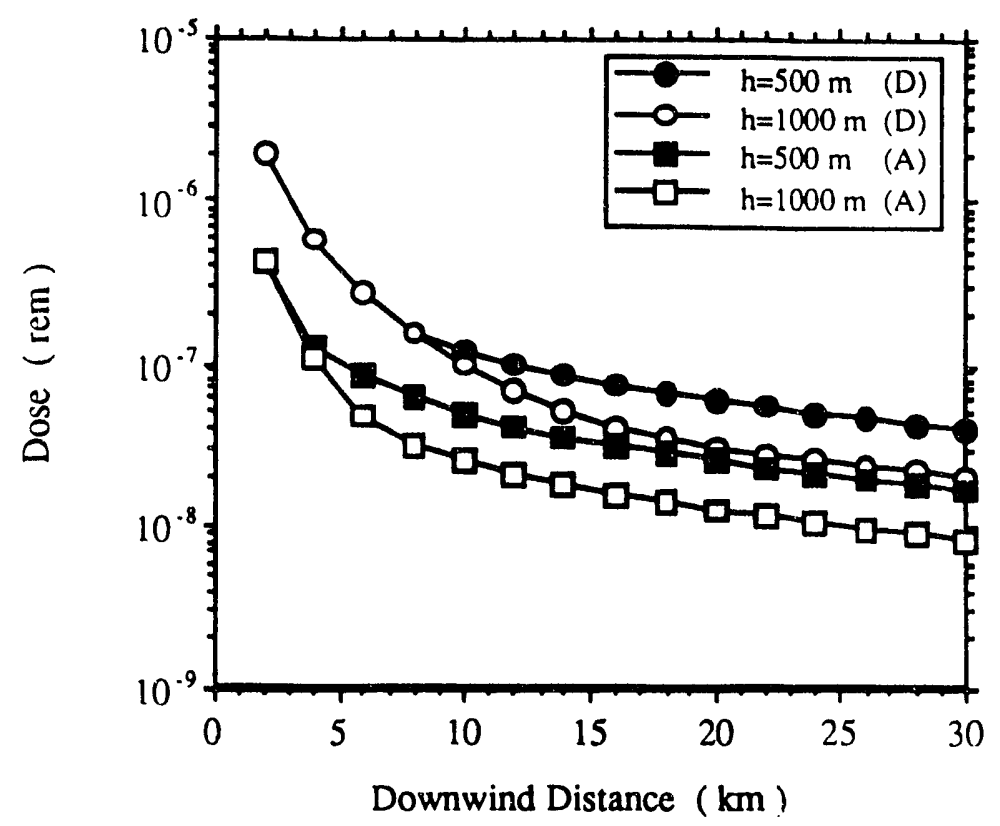

(a)

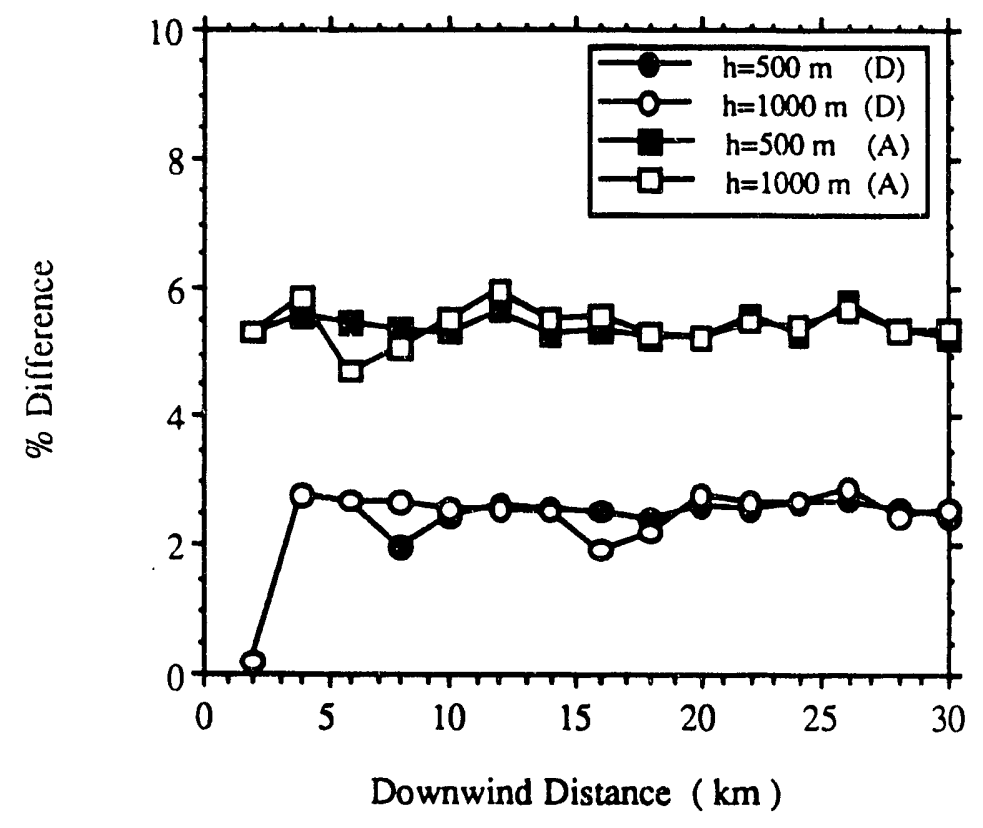

(b)

Figure 22. (a) Dose calculated by the analytic solution and (b) percent error of the numerical solution calculated by 2DPUF for various mixing depths assuming an instantaneous release (cases 1, 5, 6, 7 from Table 1) 


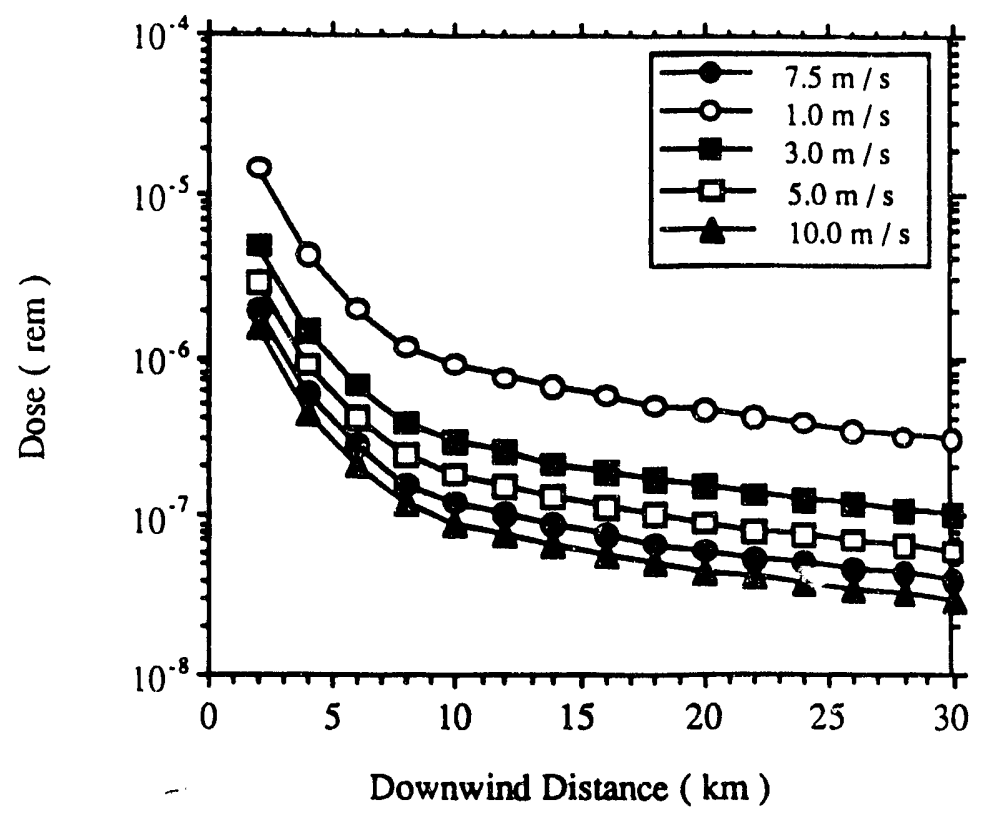

(a)

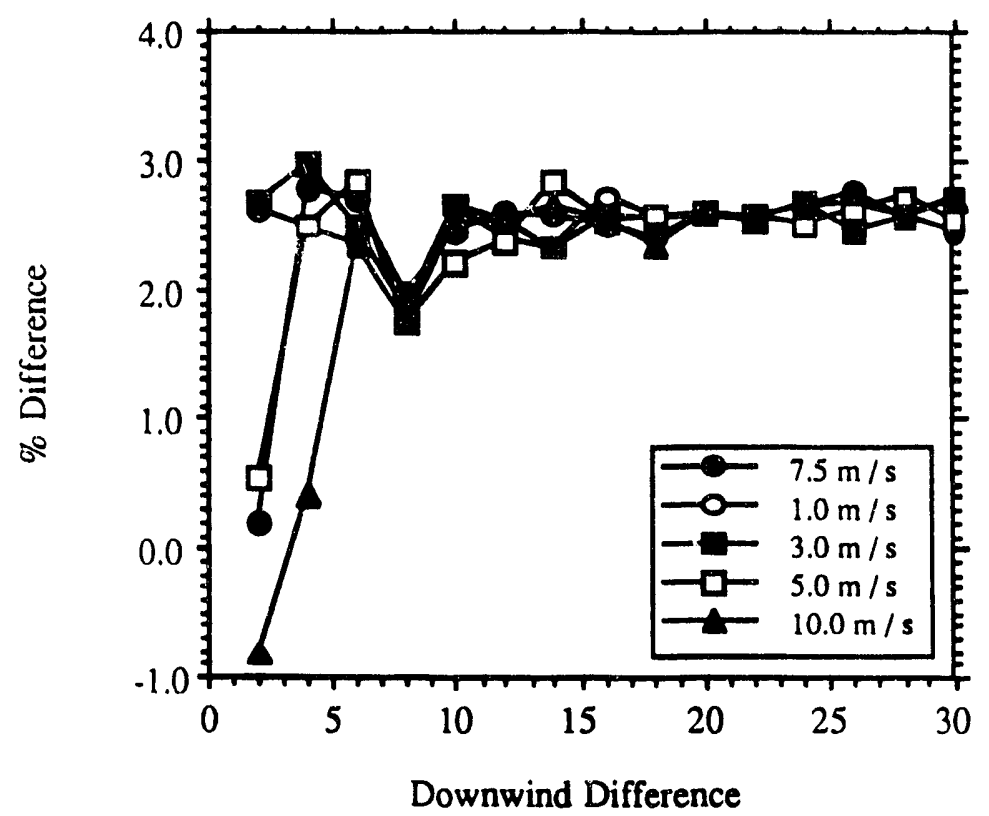

(b)

Figure 23. (a) Dose calculated by the analytic solution and (b) percent error of the numerical solution calculated by 2DPUF for various wind speeds assuming an instantaneous release (cases 1, 12, 13, 14, 15 from Table 1) 


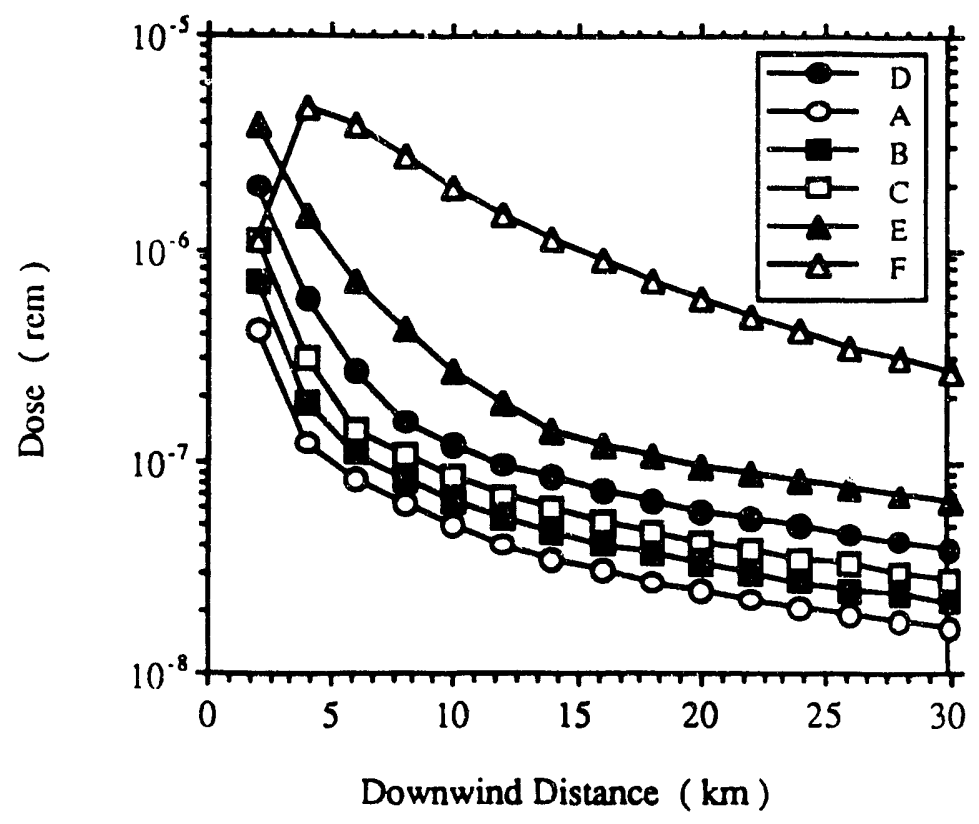

(a)

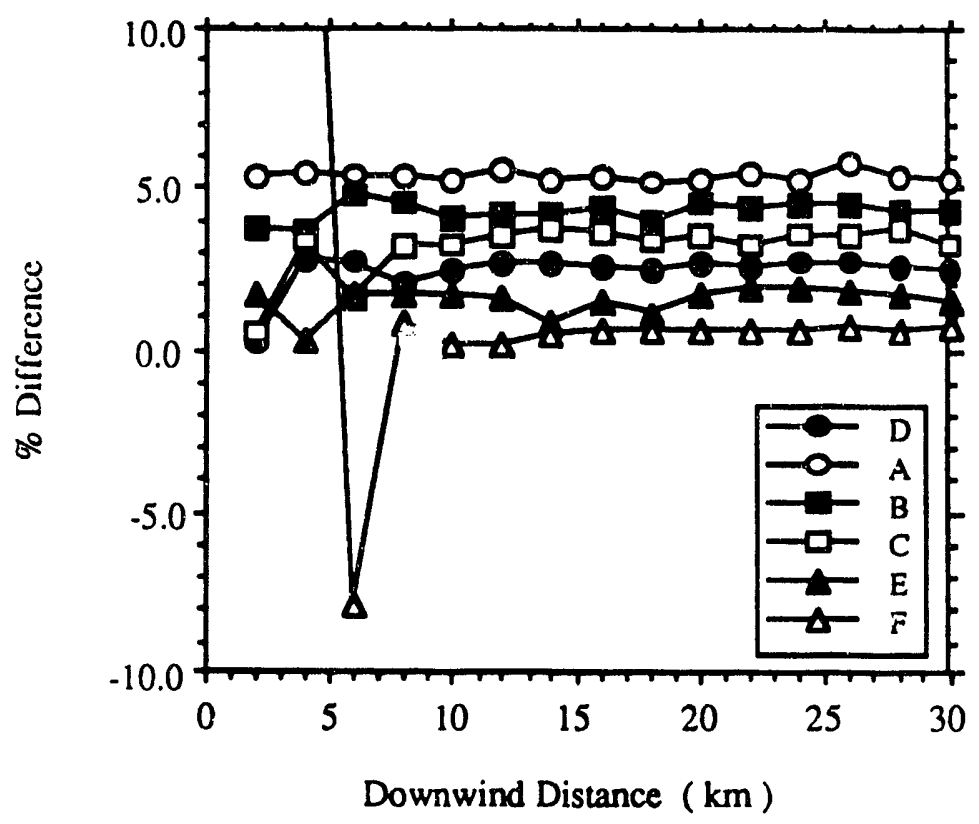

(b)

Figure 24. (a) Dose calculated by the analytic solution and (b) percent error of the numerical solution calculated by 2DPUF for various stability classes assuming an instantaneous release (cases 1, 7, 8, 9, 10, 11 from Table 1) 


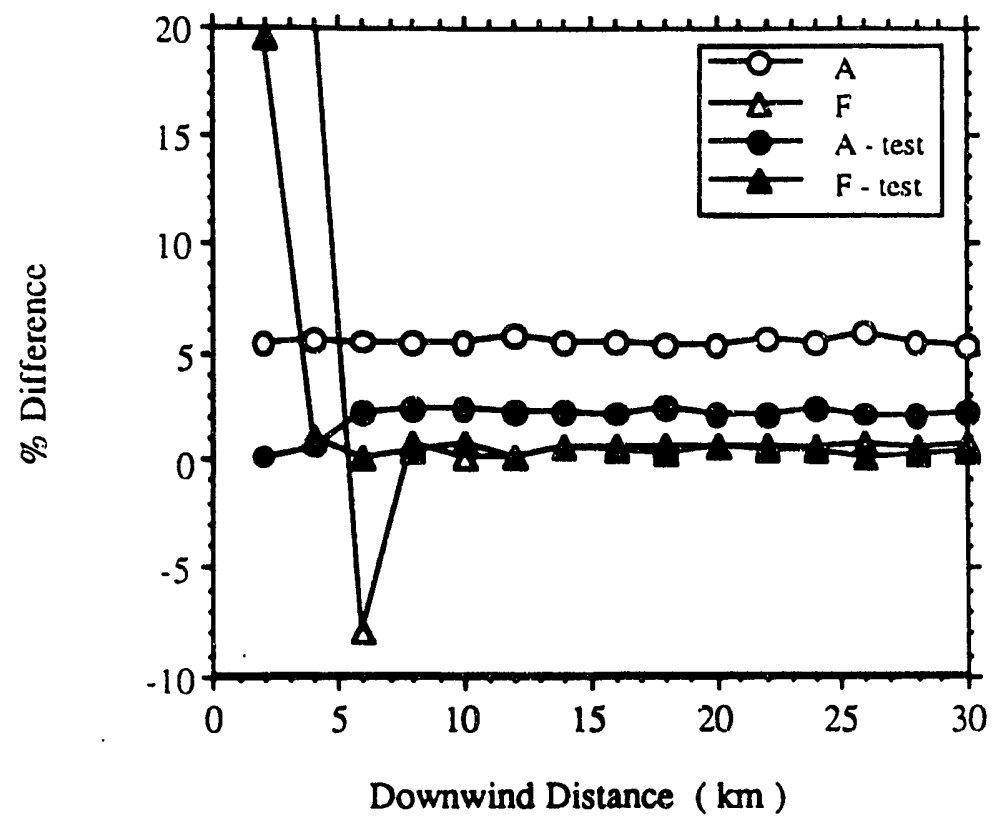

Figure 25. Percent error of the numerical solution calculated by 2DPUF where "A - test" indicates results from a simulation where the time step was reduced by a factor of three and "F - test" indicates results from a simulation where the initial time step was changed from $20 \mathrm{~s}$ to $10 \mathrm{~s}$ (cases 7, 11 from Table 1) 


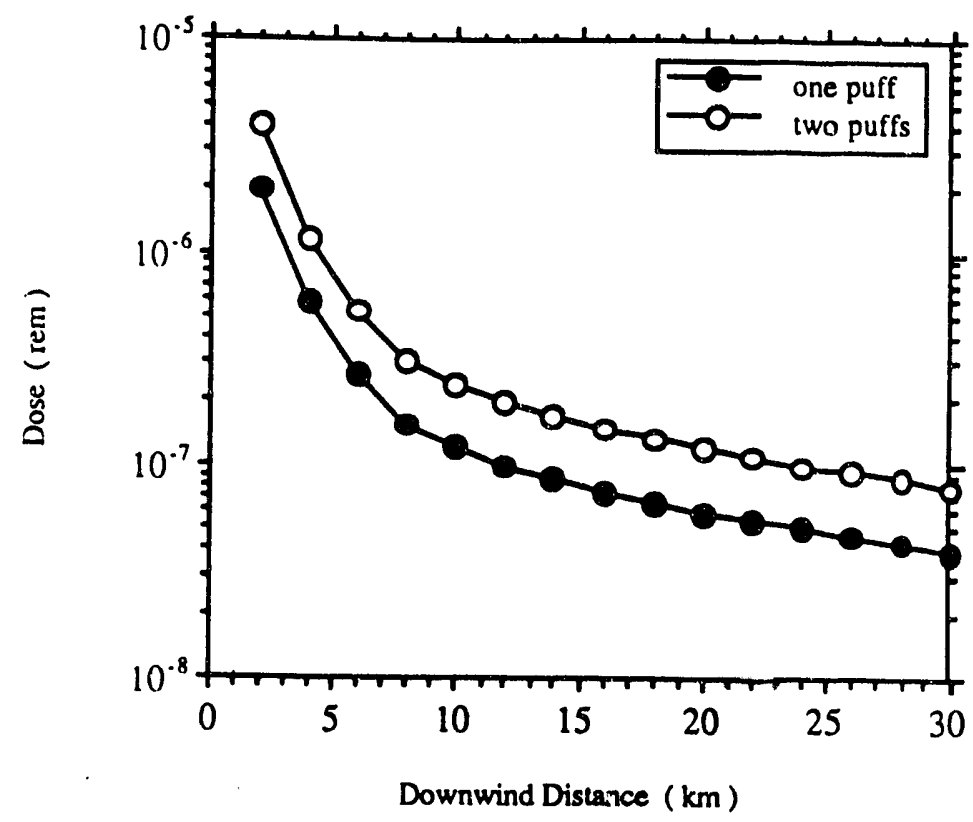

(a)

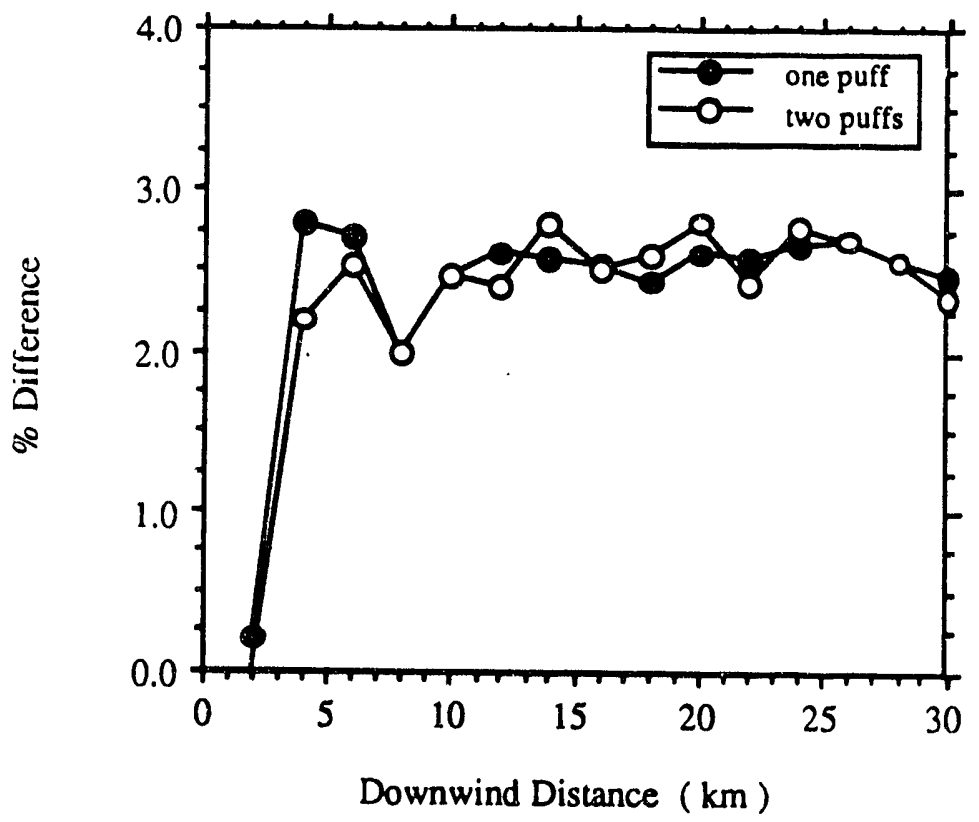

(b)

Figure 26. (a) Dose calculated by the analytic solution and (b) percent error of the numerical solution calculated by 2DPUF for one or two puffs (case 1 from Table 1) 


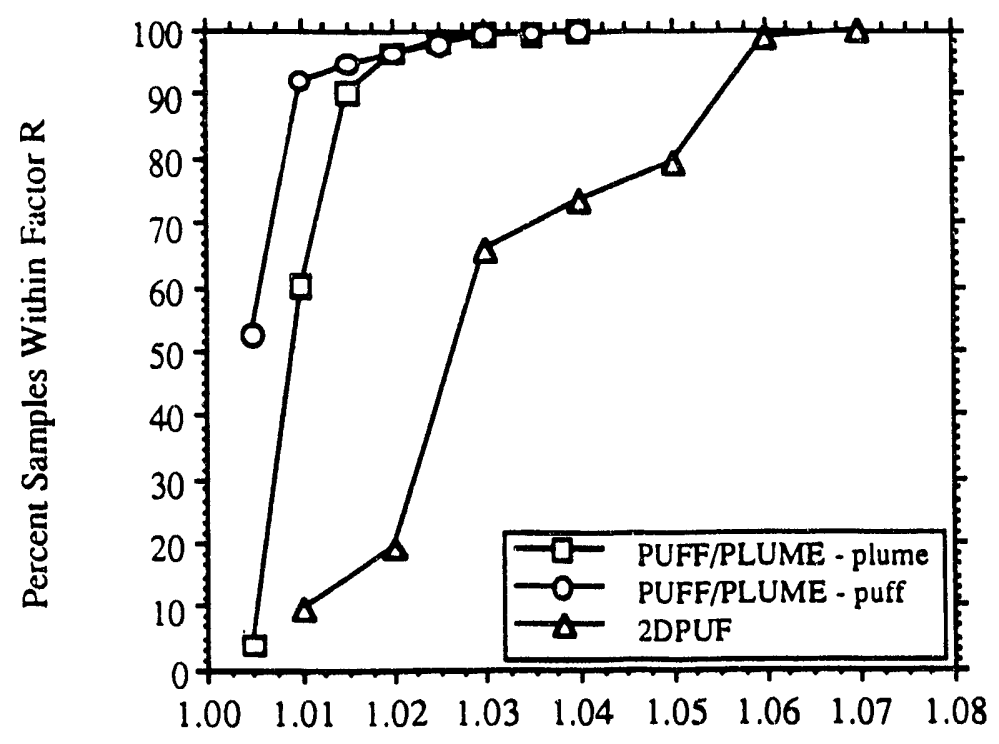

Factor $\mathbf{R}$

Figure 27. Percent of the doses computed by PUFF/PLUME and 2DPUF within a factor of $R$ of the analytic solution for the cases in Tables 1 and 2 
Table 1. Meteorological input parameters for AREA EVACUATION, PUFF/PLUME, 2DPUF, and the corresponding analytic solutions

\begin{tabular}{|r|r|r|r|r|r|r|r|}
\hline Case & Specie & \multicolumn{1}{c|}{$\begin{array}{c}\mathrm{H} \\
(\mathrm{m})\end{array}$} & $\begin{array}{c}\mathrm{V} \\
\left(\mathrm{m} \mathrm{s}^{-1}\right)\end{array}$ & $\begin{array}{c}\sigma_{\mathrm{a}} \\
(\mathrm{deg})\end{array}$ & $\begin{array}{c}\sigma_{\mathrm{e}} \\
(\mathrm{deg})\end{array}$ & Stability & \multicolumn{1}{c|}{$\begin{array}{c}\theta \\
(\mathrm{deg})\end{array}$} \\
\hline 1 & Tritium Oxide & 500 & 7.5 & 12.50 & 8.74 & $\mathrm{D}$ & 0 \\
2 & Chlorine Gas & 500 & 7.5 & 12.50 & 8.74 & $\mathrm{D}$ & 0 \\
3 & Plutonium (238) & 500 & 7.5 & 12.50 & 8.74 & $\mathrm{D}$ & 0 \\
4 & Iodine (132) & 500 & 7.5 & 12.50 & 8.74 & $\mathrm{D}$ & 0 \\
5 & Tritium Oxide & 1000 & 7.5 & 12.50 & 8.74 & $\mathrm{D}$ & 0 \\
6 & Tritium Oxide & 1000 & 7.5 & 30.00 & 20.98 & $\mathrm{~A}$ & 0 \\
7 & Tritium Oxide & 500 & 7.5 & 30.00 & 20.98 & $\mathrm{~A}$ & 0 \\
8 & Tritium Oxide & 500 & 7.5 & 22.50 & 15.73 & $\mathrm{~B}$ & 0 \\
9 & Tritium Oxide & 500 & 7.5 & 17.50 & 12.24 & $\mathrm{C}$ & 0 \\
10 & Tritium Oxide & 500 & 7.5 & 7.50 & 5.24 & $\mathrm{E}$ & 0 \\
11 & Tritium Oxide & 500 & 7.5 & 2.50 & 1.75 & $\mathrm{~F}$ & 0 \\
12 & Tritium Oxide & 500 & 1.0 & 12.50 & 8.74 & $\mathrm{D}$ & 0 \\
13 & Tritium Oxide & 500 & 3.0 & 12.50 & 8.74 & $\mathrm{D}$ & 0 \\
14 & Tritium Oxide & 500 & 5.0 & 12.50 & 8.74 & $\mathrm{D}$ & 0 \\
15 & Tritium Oxide & 500 & 10.0 & 12.50 & 8.74 & $\mathrm{D}$ & 0 \\
16 & Tritium Oxide & 500 & 7.5 & 12.50 & 8.74 & $\mathrm{D}$ & 270 \\
\hline
\end{tabular}

Table 2. Source term input parameters for AREA EVACUATION, PUFF/PLUME, 2DPUF, and the corresponding analytic solutions where the release duration is $60 \mathrm{~min}$ for continuous releases (plume) and $15 \mathrm{~min}$ for instananeous releases (puff)

\begin{tabular}{|c|c|c|c|c|c|c|}
\hline Case & Specie & $\begin{array}{c}\mathrm{D} \\
\left(\operatorname{rem} \mathrm{m}^{3}\right. \\
\left.\mathrm{Ci}^{-1} \mathrm{~s}^{-1}\right)\end{array}$ & $\begin{array}{l}\mathrm{L} \\
(\mathrm{s})\end{array}$ & $\bar{M}$ & $\begin{array}{c}\mathrm{h} \\
(\mathrm{m})\end{array}$ & $\begin{array}{c}\mathrm{Q} \\
(\mathrm{Ci} \mathrm{min}-1) \\
\text { or } \\
\left(\text { lbs } \min ^{-1}\right)\end{array}$ \\
\hline $\begin{array}{l}1 \\
2 \\
3 \\
4\end{array}$ & $\begin{array}{r}\text { Tritium Oxide } \\
\text { Chlorine Gas } \\
\text { Plutonium (238) } \\
\text { Iodine (132) }\end{array}$ & $\begin{array}{r}3.62 \mathrm{e}-2 \\
- \\
1.75 \mathrm{e}+5 \\
1.26 \mathrm{e}-1\end{array}$ & $\begin{array}{l}3.89 e+8 \\
2.77 e+9 \\
8.24 e+3\end{array}$ & 70.914 & $\begin{array}{l}61 \\
61 \\
61 \\
61\end{array}$ & $\begin{array}{l}1.0 \\
1.0 \\
1.0 \\
1.0\end{array}$ \\
\hline
\end{tabular}


Table 3. Comparison of the analytic solution (AS), Eq. (2), and the numerical results (NS) calculated by AREA EVACUATION using the input parameters given for case 1 (default case) listed in Tables 1 and 2

\begin{tabular}{|l|c|c|c|c|c|c|}
\hline $\begin{array}{c}\mathrm{x} \\
(\mathrm{km})\end{array}$ & $\begin{array}{c}\text { Dose (NS) } \\
\left(\mathrm{rem} \mathrm{h} \mathrm{r}^{-1}\right)\end{array}$ & $\begin{array}{c}\sigma_{\mathrm{y}}(\mathrm{NS}) \\
(\mathrm{m})\end{array}$ & $\begin{array}{c}\sigma_{z}(\mathrm{NS}) \\
(\mathrm{m})\end{array}$ & $\begin{array}{c}\text { Dose (AS) } \\
\left(\mathrm{rem} \mathrm{h} \mathrm{r}^{-1}\right)\end{array}$ & $\begin{array}{c}\sigma_{\mathrm{y}}(\mathrm{AS}) \\
(\mathrm{m})\end{array}$ & $\begin{array}{c}\sigma_{z}(\mathrm{AS}) \\
(\mathrm{m})\end{array}$ \\
\hline 0.0 & $.79025 \mathrm{E}-08$ & $.35868 \mathrm{E}+02$ & $.13573 \mathrm{E}+02$ & $.79025 \mathrm{E}-08$ & $.35868 \mathrm{E}+02$ & $.13573 \mathrm{E}+02$ \\
0.4 & $.14083 \mathrm{E}-05$ & $.64565 \mathrm{E}+02$ & $.22022 \mathrm{E}+02$ & $.14083 \mathrm{E}-05$ & $.64565 \mathrm{E}+02$ & $.22022 \mathrm{E}+02$ \\
0.6 & $.38937 \mathrm{E}-05$ & $.91542 \mathrm{E}+02$ & $.29165 \mathrm{E}+02$ & $.38937 \mathrm{E}-05$ & $.91542 \mathrm{E}+02$ & $.29165 \mathrm{E}+02$ \\
0.8 & $.50401 \mathrm{E}-05$ & $.11759 \mathrm{E}+03$ & $.35410 \mathrm{E}+02$ & $.50401 \mathrm{E}-05$ & $.11759 \mathrm{E}+03$ & $.35410 \mathrm{E}+02$ \\
1.0 & $.51970 \mathrm{E}-05$ & $.14351 \mathrm{E}+03$ & $.40995 \mathrm{E}+02$ & $.51970 \mathrm{E}-05$ & $.14351 \mathrm{E}+03$ & $.40995 \mathrm{E}+02$ \\
1.2 & $.49764 \mathrm{E}-05$ & $.16789 \mathrm{E}+03$ & $.46076 \mathrm{E}+02$ & $.49764 \mathrm{E}-05$ & $.16789 \mathrm{E}+03$ & $.46076 \mathrm{E}+02$ \\
1.4 & $.46305 \mathrm{E}-05$ & $.19106 \mathrm{E}+03$ & $.50757 \mathrm{E}+02$ & $.46305 \mathrm{E}-05$ & $.19106 \mathrm{E}+03$ & $.50757 \mathrm{E}+02$ \\
1.6 & $.42614 \mathrm{E}-05$ & $.21333 \mathrm{E}+03$ & $.55111 \mathrm{E}+02$ & $.42614 \mathrm{E}-05$ & $.21333 \mathrm{E}+03$ & $.55111 \mathrm{E}+02$ \\
1.8 & $.39094 \mathrm{E}-05$ & $.23487 \mathrm{E}+03$ & $.59195 \mathrm{E}+02$ & $.39094 \mathrm{E}-05$ & $.23487 \mathrm{E}+03$ & $.59195 \mathrm{E}+02$ \\
2.0 & $.35885 \mathrm{E}-05$ & $.25582 \mathrm{E}+03$ & $.63048 \mathrm{E}+02$ & $.35885 \mathrm{E}-05$ & $.25582 \mathrm{E}+03$ & $.63048 \mathrm{E}+02$ \\
2.2 & $.33015 \mathrm{E}-05$ & $.27624 \mathrm{E}+03$ & $.66704 \mathrm{E}+02$ & $.33015 \mathrm{E}-05$ & $.27624 \mathrm{E}+03$ & $.66704 \mathrm{E}+02$ \\
2.4 & $.30468 \mathrm{E}-05$ & $.29622 \mathrm{E}+03$ & $.70188 \mathrm{E}+02$ & $.30468 \mathrm{E}-05$ & $.29622 \mathrm{E}+03$ & $.70188 \mathrm{E}+02$ \\
2.6 & $.28211 \mathrm{E}-05$ & $.31579 \mathrm{E}+03$ & $.73522 \mathrm{E}+02$ & $.28211 \mathrm{E}-05$ & $.31579 \mathrm{E}+03$ & $.73522 \mathrm{E}+02$ \\
2.8 & $.26210 \mathrm{E}-05$ & $.33500 \mathrm{E}+03$ & $.76721 \mathrm{E}+02$ & $.26210 \mathrm{E}-05$ & $.33500 \mathrm{E}+03$ & $.76721 \mathrm{E}+02$ \\
3.0 & $.24431 \mathrm{E}-05$ & $.35388 \mathrm{E}+03$ & $.79800 \mathrm{E}+02$ & $.24431 \mathrm{E}-05$ & $.35388 \mathrm{E}+03$ & $.79800 \mathrm{E}+02$ \\
\hline
\end{tabular}

Table 4. Same as Table 3, but for case 2 and analytic solution given by Eq. (1)

\begin{tabular}{|c|c|c|c|c|c|c|}
\hline $\begin{array}{c}\mathrm{x} \\
(\mathrm{km})\end{array}$ & $\begin{array}{c}\text { Conc. (NS) } \\
(\mathrm{ppm})\end{array}$ & $\begin{array}{c}\sigma_{\mathrm{y}}(\mathrm{NS}) \\
(\mathrm{m})\end{array}$ & $\begin{array}{c}\sigma_{\mathrm{z}}(\mathrm{NS}) \\
(\mathrm{m})\end{array}$ & $\begin{array}{c}\text { Conc. (AS) } \\
(\mathrm{ppm})\end{array}$ & $\begin{array}{c}\sigma_{\mathrm{y}}(\mathrm{AS}) \\
(\mathrm{m})\end{array}$ & $\begin{array}{c}\sigma_{\mathrm{z}}(\mathrm{AS}) \\
(\mathrm{m})\end{array}$ \\
\hline 0.2 & $.86761 \mathrm{E}-05$ & $.35868 \mathrm{E}+02$ & $.13573 \mathrm{E}+02$ & $.86761 \mathrm{E}-05$ & $.35868 \mathrm{E}+02$ & $.13573 \mathrm{E}+02$ \\
0.4 & $.15462 \mathrm{E}-02$ & $.64565 \mathrm{E}+02$ & $.22022 \mathrm{E}+02$ & $.15462 \mathrm{E}-02$ & $.64565 \mathrm{E}+02$ & $.22022 \mathrm{E}+02$ \\
0.6 & $.42749 \mathrm{E}-02$ & $.91542 \mathrm{E}+02$ & $.29165 \mathrm{E}+02$ & $.42749 \mathrm{E}-02$ & $.91542 \mathrm{E}+02$ & $.29165 \mathrm{E}+02$ \\
0.8 & $.55335 \mathrm{E}-02$ & $.11759 \mathrm{E}+03$ & $.35410 \mathrm{E}+02$ & $.55335 \mathrm{E}-02$ & $.11759 \mathrm{E}+03$ & $.35410 \mathrm{E}+02$ \\
1.0 & $.57057 \mathrm{E}-02$ & $.14351 \mathrm{E}+03$ & $.40995 \mathrm{E}+02$ & $.57057 \mathrm{E}-02$ & $.14351 \mathrm{E}+03$ & $.40995 \mathrm{E}+02$ \\
1.2 & $.54635 \mathrm{E}-02$ & $.16789 \mathrm{E}+03$ & $.46076 \mathrm{E}+02$ & $.54635 \mathrm{E}-02$ & $.16789 \mathrm{E}+03$ & $.46076 \mathrm{E}+02$ \\
1.4 & $.50838 \mathrm{E}-02$ & $.19106 \mathrm{E}+03$ & $.50757 \mathrm{E}+02$ & $.50838 \mathrm{E}-02$ & $.19106 \mathrm{E}+03$ & $.50757 \mathrm{E}+02$ \\
1.6 & $.46785 \mathrm{E}-02$ & $.21333 \mathrm{E}+03$ & $.55111 \mathrm{E}+02$ & $.46785 \mathrm{E}-02$ & $.21333 \mathrm{E}+03$ & $.55111 \mathrm{E}+02$ \\
1.8 & $.42921 \mathrm{E}-02$ & $.23487 \mathrm{E}+03$ & $.59195 \mathrm{E}+02$ & $.42921 \mathrm{E}-02$ & $.23487 \mathrm{E}+03$ & $.59195 \mathrm{E}+02$ \\
2.0 & $.39398 \mathrm{E}-02$ & $.25582 \mathrm{E}+03$ & $.63048 \mathrm{E}+02$ & $.39398 \mathrm{E}-02$ & $.25582 \mathrm{E}+03$ & $.63048 \mathrm{E}+02$ \\
2.2 & $.36247 \mathrm{E}-02$ & $.27624 \mathrm{E}+03$ & $.66704 \mathrm{E}+02$ & $.36247 \mathrm{E}-02$ & $.27624 \mathrm{E}+03$ & $.66704 \mathrm{E}+02$ \\
2.4 & $.33451 \mathrm{E}-02$ & $.29622 \mathrm{E}+03$ & $.70188 \mathrm{E}+02$ & $.33451 \mathrm{E}-02$ & $.29622 \mathrm{E}+03$ & $.70188 \mathrm{E}+02$ \\
2.6 & $.30973 \mathrm{E}-02$ & $.31579 \mathrm{E}+03$ & $.73522 \mathrm{E}+02$ & $.30973 \mathrm{E}-02$ & $.31579 \mathrm{E}+03$ & $.73522 \mathrm{E}+02$ \\
2.8 & $.28776 \mathrm{E}-02$ & $.33500 \mathrm{E}+03$ & $.76721 \mathrm{E}+02$ & $.28776 \mathrm{E}-02$ & $.33500 \mathrm{E}+03$ & $.76721 \mathrm{E}+02$ \\
3.0 & $.26822 \mathrm{E}-02$ & $.35388 \mathrm{E}+03$ & $.79800 \mathrm{E}+02$ & $.26822 \mathrm{E}-02$ & $.35388 \mathrm{E}+03$ & $.79800 \mathrm{E}+02$ \\
\hline
\end{tabular}


Table 5. Same as Table 3, but for case 3

\begin{tabular}{|c|c|c|c|c|c|c|}
\hline $\begin{array}{c}\mathrm{x} \\
(\mathrm{km})\end{array}$ & $\begin{array}{c}\text { Dose }(\mathrm{NS}) \\
\left(\mathrm{rem} \mathrm{h} \mathrm{r}^{\mathrm{i}}\right)\end{array}$ & $\begin{array}{c}\sigma_{\mathrm{y}}(\mathrm{NS}) \\
(\mathrm{m})\end{array}$ & $\begin{array}{c}\sigma_{\mathrm{z}}(\mathrm{NS}) \\
(\mathrm{m})\end{array}$ & $\begin{array}{c}\text { Dose }(\mathrm{AS}) \\
\left.(\mathrm{rem} \mathrm{h})^{-1}\right)\end{array}$ & $\begin{array}{c}\sigma_{\mathrm{y}}(\mathrm{AS}) \\
(\mathrm{m})\end{array}$ & $\begin{array}{c}\sigma_{\mathrm{z}}(\mathrm{AS}) \\
(\mathrm{m})\end{array}$ \\
\hline 0.2 & $.38203 \mathrm{E}-01$ & $.35868 \mathrm{E}+02$ & $.13573 \mathrm{E}+02$ & $.38203 \mathrm{E}-01$ & $.35868 \mathrm{E}+02$ & $.13573 \mathrm{E}+02$ \\
0.4 & $.68083 \mathrm{E}+01$ & $.64565 \mathrm{E}+02$ & $.22022 \mathrm{E}+02$ & $.68083 \mathrm{E}+01$ & $.64565 \mathrm{E}+02$ & $.22022 \mathrm{E}+02$ \\
0.6 & $.18823 \mathrm{E}+02$ & $.91542 \mathrm{E}+02$ & $.29165 \mathrm{E}+02$ & $.18823 \mathrm{E}+02$ & $.91542 \mathrm{E}+02$ & $.29165 \mathrm{E}+02$ \\
0.8 & $.24365 \mathrm{E}+02$ & $.11759 \mathrm{E}+03$ & $.35410 \mathrm{E}+02$ & $.24365 \mathrm{E}+02$ & $.11759 \mathrm{E}+03$ & $.35410 \mathrm{E}+02$ \\
1.0 & $.25124 \mathrm{E}+02$ & $.14351 \mathrm{E}+03$ & $.40995 \mathrm{E}+02$ & $.25124 \mathrm{E}+02$ & $.14351 \mathrm{E}+03$ & $.40995 \mathrm{E}+02$ \\
1.2 & $.24057 \mathrm{E}+02$ & $.16789 \mathrm{E}+03$ & $.46076 \mathrm{E}+02$ & $.24057 \mathrm{E}+02$ & $.16789 \mathrm{E}+03$ & $.46076 \mathrm{E}+02$ \\
1.4 & $.22385 \mathrm{E}+02$ & $.19106 \mathrm{E}+03$ & $.50757 \mathrm{E}+02$ & $.22385 \mathrm{E}+02$ & $.19106 \mathrm{E}+03$ & $.50757 \mathrm{E}+02$ \\
1.6 & $.20600 \mathrm{E}+02$ & $.21333 \mathrm{E}+03$ & $.55111 \mathrm{E}+02$ & $.20600 \mathrm{E}+02$ & $.21333 \mathrm{E}+03$ & $.55111 \mathrm{E}+02$ \\
1.8 & $.18899 \mathrm{E}+02$ & $.23487 \mathrm{E}+03$ & $.59195 \mathrm{E}+02$ & $.18899 \mathrm{E}+02$ & $.23487 \mathrm{E}+03$ & $.59195 \mathrm{E}+02$ \\
2.0 & $.17348 \mathrm{E}+02$ & $.25582 \mathrm{E}+03$ & $.63048 \mathrm{E}+02$ & $.17348 \mathrm{E}+02$ & $.25582 \mathrm{E}+03$ & $.63048 \mathrm{E}+02$ \\
2.2 & $.15960 \mathrm{E}+02$ & $.27624 \mathrm{E}+03$ & $.66704 \mathrm{E}+02$ & $.15960 \mathrm{E}+02$ & $.27624 \mathrm{E}+03$ & $.66704 \mathrm{E}+02$ \\
2.4 & $.14729 \mathrm{E}+02$ & $.29622 \mathrm{E}+03$ & $.70188 \mathrm{E}+02$ & $.14729 \mathrm{E}+02$ & $.29622 \mathrm{E}+03$ & $.70188 \mathrm{E}+02$ \\
2.6 & $.13638 \mathrm{E}+02$ & $.31579 \mathrm{E}+03$ & $.73522 \mathrm{E}+02$ & $.13638 \mathrm{E}+02$ & $.31579 \mathrm{E}+03$ & $.73522 \mathrm{E}+02$ \\
2.8 & $.12671 \mathrm{E}+02$ & $.33500 \mathrm{E}+03$ & $.76721 \mathrm{E}+02$ & $.12671 \mathrm{E}+02$ & $.33500 \mathrm{E}+03$ & $.76721 \mathrm{E}+02$ \\
3.0 & $.11810 \mathrm{E}+02$ & $.35388 \mathrm{E}+03$ & $.79800 \mathrm{E}+02$ & $.11810 \mathrm{E}+02$ & $.35388 \mathrm{E}+03$ & $.79800 \mathrm{E}+02$ \\
\hline
\end{tabular}

Table 6. Same as Table 3, but for case 4

\begin{tabular}{|c|c|c|c|c|c|c|}
\hline $\begin{array}{c}\mathrm{x} \\
(\mathrm{km})\end{array}$ & $\begin{array}{c}\text { Dose (NS) } \\
\left(\mathrm{rem} \mathrm{h} \mathrm{h}^{-1}\right)\end{array}$ & $\begin{array}{c}\sigma_{\mathrm{y}}(\mathrm{NS}) \\
(\mathrm{m})\end{array}$ & $\begin{array}{c}\sigma_{\mathrm{z}}(\mathrm{NS}) \\
(\mathrm{m})\end{array}$ & $\begin{array}{c}\text { Dose }(\mathrm{AS}) \\
(\mathrm{rem} \mathrm{hr})\end{array}$ & $\begin{array}{c}\sigma_{\mathrm{y}}(\mathrm{AS}) \\
(\mathrm{m})\end{array}$ & $\begin{array}{c}\sigma_{\mathrm{z}}(\mathrm{AS}) \\
(\mathrm{m})\end{array}$ \\
\hline 0.2 & $.27444 \mathrm{E}-07$ & $.35868 \mathrm{E}+02$ & $.13573 \mathrm{E}+02$ & $.27444 \mathrm{E}-07$ & $.35868 \mathrm{E}+02$ & $.13573 \mathrm{E}+02$ \\
0.4 & $.48800 \mathrm{E}-05$ & $.64565 \mathrm{E}+02$ & $.22022 \mathrm{E}+02$ & $.48800 \mathrm{E}-05$ & $.64565 \mathrm{E}+02$ & $.22022 \mathrm{E}+02$ \\
0.6 & $.13462 \mathrm{E}-04$ & $.91542 \mathrm{E}+02$ & $.29165 \mathrm{E}+02$ & $.13462 \mathrm{E}-04$ & $.91542 \mathrm{E}+02$ & $.29165 \mathrm{E}+02$ \\
0.8 & $.17386 \mathrm{E}-04$ & $.11759 \mathrm{E}+03$ & $.35410 \mathrm{E}+02$ & $.17386 \mathrm{E}-04$ & $.11759 \mathrm{E}+03$ & $.35410 \mathrm{E}+02$ \\
1.0 & $.17887 \mathrm{E}-04$ & $.14351 \mathrm{E}+03$ & $.40995 \mathrm{E}+02$ & $.17887 \mathrm{E}-04$ & $.14351 \mathrm{E}+03$ & $.40995 \mathrm{E}+02$ \\
1.2 & $.17089 \mathrm{E}-04$ & $.16789 \mathrm{E}+03$ & $.46076 \mathrm{E}+02$ & $.17089 \mathrm{E}-04$ & $.16789 \mathrm{E}+03$ & $.46076 \mathrm{E}+02$ \\
1.4 & $.15866 \mathrm{E}-04$ & $.19106 \mathrm{E}+03$ & $.50757 \mathrm{E}+02$ & $.15866 \mathrm{E}-04$ & $.19106 \mathrm{E}+03$ & $.50757 \mathrm{E}+02$ \\
1.6 & $.14569 \mathrm{E}-04$ & $.21333 \mathrm{E}+03$ & $.55111 \mathrm{E}+02$ & $.14569 \mathrm{E}-04$ & $.21333 \mathrm{E}+03$ & $.55111 \mathrm{E}+02$ \\
1.8 & $.13335 \mathrm{E}-04$ & $.23487 \mathrm{E}+03$ & $.59195 \mathrm{E}+02$ & $.13335 \mathrm{E}-04$ & $.23487 \mathrm{E}+03$ & $.59195 \mathrm{E}+02$ \\
2.0 & $.12213 \mathrm{E}-04$ & $.25582 \mathrm{E}+03$ & $.63048 \mathrm{E}+02$ & $.12213 \mathrm{E}-04$ & $.25582 \mathrm{E}+03$ & $.63048 \mathrm{E}+02$ \\
2.2 & $.11211 \mathrm{E}-04$ & $.27624 \mathrm{E}+03$ & $.66704 \mathrm{E}+02$ & $.11211 \mathrm{E}-04$ & $.27624 \mathrm{E}+03$ & $.66704 \mathrm{E}+02$ \\
2.4 & $.10323 \mathrm{E}-04$ & $.29622 \mathrm{E}+03$ & $.70188 \mathrm{E}+02$ & $.10323 \mathrm{E}-04$ & $.29622 \mathrm{E}+03$ & $.70188 \mathrm{E}+02$ \\
2.6 & $.95372 \mathrm{E}-05$ & $.31579 \mathrm{E}+03$ & $.73522 \mathrm{E}+02$ & $.95372 \mathrm{E}-05$ & $.31579 \mathrm{E}+03$ & $.73522 \mathrm{E}+02$ \\
2.8 & $.88407 \mathrm{E}-05$ & $.33500 \mathrm{E}+03$ & $.76721 \mathrm{E}+02$ & $.88408 \mathrm{E}-05$ & $.33500 \mathrm{E}+03$ & $.76721 \mathrm{E}+02$ \\
3.0 & $.82221 \mathrm{E}-05$ & $.35388 \mathrm{E}+03$ & $.79800 \mathrm{E}+02$ & $.82221 \mathrm{E}-05$ & $.35388 \mathrm{E}+03$ & $.79800 \mathrm{E}+02$ \\
\hline
\end{tabular}


Table 7. Same as Table 3, but for case 5

\begin{tabular}{|c|c|c|c|c|c|c|}
\hline $\begin{array}{c}\mathrm{x} \\
(\mathrm{km})\end{array}$ & $\begin{array}{c}\text { Dose }(\mathrm{NS}) \\
\left(\mathrm{rem} \mathrm{h} \mathrm{r}^{-1}\right)\end{array}$ & $\begin{array}{c}\sigma_{\mathrm{y}}(\mathrm{NS}) \\
(\mathrm{m})\end{array}$ & $\begin{array}{c}\sigma_{\mathrm{z}}(\mathrm{NS}) \\
(\mathrm{m})\end{array}$ & $\begin{array}{c}\text { Dose }(\mathrm{AS}) \\
(\mathrm{rem} \mathrm{hr})\end{array}$ & $\begin{array}{c}\sigma_{\mathrm{y}}(\mathrm{AS}) \\
(\mathrm{m})\end{array}$ & $\begin{array}{c}\sigma_{\mathrm{z}}(\mathrm{AS}) \\
(\mathrm{m})\end{array}$ \\
\hline 0.2 & $.79025 \mathrm{E}-08$ & $.35868 \mathrm{E}+02$ & $.13573 \mathrm{E}+02$ & $.79025 \mathrm{E}-08$ & $.35868 \mathrm{E}+02$ & $.13573 \mathrm{E}+02$ \\
0.4 & $.14083 \mathrm{E}-05$ & $.64565 \mathrm{E}+02$ & $.22022 \mathrm{E}+02$ & $.14083 \mathrm{E}-05$ & $.64565 \mathrm{E}+02$ & $.22022 \mathrm{E}+02$ \\
0.6 & $.38937 \mathrm{E}-05$ & $.91542 \mathrm{E}+02$ & $.29165 \mathrm{E}+02$ & $.38937 \mathrm{E}-05$ & $.91542 \mathrm{E}+02$ & $.29165 \mathrm{E}+02)$ \\
0.8 & $.50401 \mathrm{E}-05$ & $.11759 \mathrm{E}+03$ & $.35410 \mathrm{E}+02$ & $.50401 \mathrm{E}-05$ & $.11759 \mathrm{E}+03$ & $.35410 \mathrm{E}+02$ \\
1.0 & $.51970 \mathrm{E}-05$ & $.14351 \mathrm{E}+03$ & $.40995 \mathrm{E}+02$ & $.51970 \mathrm{E}-05$ & $.14351 \mathrm{E}+03$ & $.40995 \mathrm{E}+02$ \\
1.2 & $.49764 \mathrm{E}-05$ & $.16789 \mathrm{E}+03$ & $.46076 \mathrm{E}+02$ & $.49764 \mathrm{E}-05$ & $.16789 \mathrm{E}+03$ & $.46076 \mathrm{E}+02$ \\
1.4 & $.46305 \mathrm{E}-05$ & $.19106 \mathrm{E}+03$ & $.50757 \mathrm{E}+02$ & $.46305 \mathrm{E}-05$ & $.19106 \mathrm{E}+03$ & $.50757 \mathrm{E}+02$ \\
1.6 & $.42614 \mathrm{E}-05$ & $.21333 \mathrm{E}+03$ & $.55111 \mathrm{E}+02$ & $.42614 \mathrm{E}-05$ & $.21333 \mathrm{E}+03$ & $.55111 \mathrm{E}+02$ \\
1.8 & $.39094 \mathrm{E}-05$ & $.23487 \mathrm{E}+03$ & $.59195 \mathrm{E}+02$ & $.39094 \mathrm{E}-05$ & $.23487 \mathrm{E}+03$ & $.59195 \mathrm{E}+02$ \\
2.0 & $.35885 \mathrm{E}-05$ & $.25582 \mathrm{E}+03$ & $.63048 \mathrm{E}+02$ & $.35885 \mathrm{E}-05$ & $.25582 \mathrm{E}+03$ & $.63048 \mathrm{E}+02$ \\
2.2 & $.33015 \mathrm{E}-05$ & $.27624 \mathrm{E}+03$ & $.66704 \mathrm{E}+02$ & $.33015 \mathrm{E}-05$ & $.27624 \mathrm{E}+03$ & $.66704 \mathrm{E}+02$ \\
2.4 & $.30468 \mathrm{E}-05$ & $.29622 \mathrm{E}+03$ & $.70188 \mathrm{E}+02$ & $.30468 \mathrm{E}-05$ & $.29622 \mathrm{E}+03$ & $.70188 \mathrm{E}+02$ \\
2.6 & $.28211 \mathrm{E}-05$ & $.31579 \mathrm{E}+03$ & $.73522 \mathrm{E}+02$ & $.28211 \mathrm{E}-05$ & $.31579 \mathrm{E}+03$ & $.73522 \mathrm{E}+02$ \\
2.8 & $.26210 \mathrm{E}-05$ & $.33500 \mathrm{E}+03$ & $.76721 \mathrm{E}+02$ & $.26210 \mathrm{E}-05$ & $.33500 \mathrm{E}+03$ & $.76721 \mathrm{E}+02$ \\
3.0 & $.24431 \mathrm{E}-05$ & $.35388 \mathrm{E}+03$ & $.79800 \mathrm{E}+02$ & $.24431 \mathrm{E}-05$ & $.35388 \mathrm{E}+03$ & $.79800 \mathrm{E}+02$ \\
\hline
\end{tabular}

Table 8. Same as Table 3, but for case 6

\begin{tabular}{|c|c|c|c|c|c|c|}
\hline $\begin{array}{c}\mathrm{x} \\
(\mathrm{km})\end{array}$ & $\begin{array}{c}\text { Dose (NS) } \\
\left(\mathrm{rem} \mathrm{h} \mathrm{h}^{-1}\right)\end{array}$ & $\begin{array}{c}\sigma_{\mathrm{y}}(\mathrm{NS}) \\
(\mathrm{m})\end{array}$ & $\begin{array}{c}\sigma_{\mathrm{z}}(\mathrm{NS}) \\
(\mathrm{m})\end{array}$ & $\begin{array}{c}\text { Dose }(\mathrm{AS}) \\
(\mathrm{rem} \mathrm{hr})\end{array}$ & $\begin{array}{c}\sigma_{\mathrm{y}}(\mathrm{AS}) \\
(\mathrm{m})\end{array}$ & $\begin{array}{c}\sigma_{\mathrm{z}}(\mathrm{AS}) \\
(\mathrm{m})\end{array}$ \\
\hline 0.2 & $.96223 \mathrm{E}-05$ & $.81816 \mathrm{E}+02$ & $.43048 \mathrm{E}+02$ & $.96223 \mathrm{E}-05$ & $.81816 \mathrm{E}+02$ & $.43048 \mathrm{E}+02$ \\
0.4 & $.56378 \mathrm{E}-05$ & $.15069 \mathrm{E}+03$ & $.83048 \mathrm{E}+02$ & $.56378 \mathrm{E}-05$ & $.15069 \mathrm{E}+03$ & $.83048 \mathrm{E}+02$ \\
0.6 & $.30820 \mathrm{E}-05$ & $.21543 \mathrm{E}+03$ & $.12305 \mathrm{E}+03$ & $.30820 \mathrm{E}-05$ & $.21543 \mathrm{E}+03$ & $.12305 \mathrm{E}+03$ \\
0.8 & $.19005 \mathrm{E}-05$ & $.27795 \mathrm{E}+03$ & $.16305 \mathrm{E}+03$ & $.19005 \mathrm{E}-05$ & $.27795 \mathrm{E}+03$ & $.16305 \mathrm{E}+03$ \\
1.0 & $.12784 \mathrm{E}-05$ & $.34016 \mathrm{E}+03$ & $.20305 \mathrm{E}+03$ & $.12784 \mathrm{E}-05$ & $.34016 \mathrm{E}+03$ & $.20305 \mathrm{E}+03$ \\
1.2 & $.92372 \mathrm{E}-06$ & $.39868 \mathrm{E}+03$ & $.24305 \mathrm{E}+03$ & $.92373 \mathrm{E}-06$ & $.39868 \mathrm{E}+03$ & $.24305 \mathrm{E}+03$ \\
1.4 & $.70188 \mathrm{E}-06$ & $.45427 \mathrm{E}+03$ & $.28305 \mathrm{E}+03$ & $.70189 \mathrm{E}-06$ & $.45427 \mathrm{E}+03$ & $.28305 \mathrm{E}+03$ \\
1.6 & $.55322 \mathrm{E}-06$ & $.50772 \mathrm{E}+03$ & $.32305 \mathrm{E}+03$ & $.55322 \mathrm{E}-06$ & $.50772 \mathrm{E}+03$ & $.32305 \mathrm{E}+03$ \\
1.8 & $.44842 \mathrm{E}-06$ & $.55943 \mathrm{E}+03$ & $.36305 \mathrm{E}+03$ & $.44842 \mathrm{E}-06$ & $.55943 \mathrm{E}+03$ & $.36305 \mathrm{E}+03$ \\
2.0 & $.37160 \mathrm{E}-06$ & $.60970 \mathrm{E}+03$ & $.40305 \mathrm{E}+03$ & $.37160 \mathrm{E}-06$ & $.60970 \mathrm{E}+03$ & $.40305 \mathrm{E}+03$ \\
2.2 & $.31351 \mathrm{E}-06$ & $.65872 \mathrm{E}+03$ & $.44305 \mathrm{E}+03$ & $.31351 \mathrm{E}-06$ & $.65872 \mathrm{E}+03$ & $.44305 \mathrm{E}+03$ \\
2.4 & $.26845 \mathrm{E}-06$ & $.70665 \mathrm{E}+03$ & $.48305 \mathrm{E}+03$ & $.26845 \mathrm{E}-06$ & $.70665 \mathrm{E}+03$ & $.48305 \mathrm{E}+03$ \\
2.6 & $.23274 \mathrm{E}-06$ & $.75362 \mathrm{E}+03$ & $.52305 \mathrm{E}+03$ & $.23274 \mathrm{E}-06$ & $.75362 \mathrm{E}+03$ & $.52305 \mathrm{E}+03$ \\
2.8 & $.20393 \mathrm{E}-06$ & $.79973 \mathrm{E}+03$ & $.56305 \mathrm{E}+03$ & $.20393 \mathrm{E}-06$ & $.79973 \mathrm{E}+03$ & $.56305 \mathrm{E}+03$ \\
3.0 & $.18033 \mathrm{E}-06$ & $.84505 \mathrm{E}+03$ & $.60305 \mathrm{E}+03$ & $.18033 \mathrm{E}-06$ & $.84505 \mathrm{E}+03$ & $.60305 \mathrm{E}+03$ \\
\hline
\end{tabular}


Table 9. Same as Table 3, but for case 7

\begin{tabular}{|c|c|c|c|c|c|c|}
\hline $\begin{array}{c}\mathrm{x} \\
(\mathrm{km})\end{array}$ & $\begin{array}{c}\text { Dose (NS) } \\
\left.(\mathrm{rem} \mathrm{h})^{-1}\right)\end{array}$ & $\begin{array}{c}\sigma_{\mathrm{y}}(\mathrm{NS}) \\
(\mathrm{m})\end{array}$ & $\begin{array}{c}\sigma_{\mathrm{z}}(\mathrm{NS}) \\
(\mathrm{m})\end{array}$ & $\begin{array}{c}\text { Dose }(\mathrm{AS}) \\
(\mathrm{rem} \mathrm{h})\end{array}$ & $\begin{array}{c}\sigma_{\mathrm{y}}(\mathrm{AS}) \\
(\mathrm{m})\end{array}$ & $\begin{array}{c}\sigma_{\mathrm{z}}(\mathrm{AS}) \\
(\mathrm{m})\end{array}$ \\
\hline 0.2 & $.96223 \mathrm{E}-05$ & $.81816 \mathrm{E}+02$ & $.43048 \mathrm{E}+02$ & $.96223 \mathrm{E}-05$ & $.81816 \mathrm{E}+02$ & $.43048 \mathrm{E}+02$ \\
0.4 & $.56378 \mathrm{E}-05$ & $.15069 \mathrm{E}+03$ & $.83048 \mathrm{E}+02$ & $.56378 \mathrm{E}-05$ & $.15069 \mathrm{E}+03$ & $.83048 \mathrm{E}+02$ \\
0.6 & $.30820 \mathrm{E}-05$ & $.21543 \mathrm{E}+03$ & $.12305 \mathrm{E}+03$ & $.30820 \mathrm{E}-05$ & $.21543 \mathrm{E}+03$ & $.12305 \mathrm{E}+03$ \\
0.8 & $.19005 \mathrm{E}-05$ & $.27795 \mathrm{E}+03$ & $.16305 \mathrm{E}+03$ & $.19005 \mathrm{E}-05$ & $.27795 \mathrm{E}+03$ & $.16305 \mathrm{E}+03$ \\
1.0 & $.12784 \mathrm{E}-05$ & $.34016 \mathrm{E}+03$ & $.20305 \mathrm{E}+03$ & $.12784 \mathrm{E}-05$ & $.34016 \mathrm{E}+03$ & $.20305 \mathrm{E}+03$ \\
1.2 & $.92372 \mathrm{E}-06$ & $.39868 \mathrm{E}+03$ & $.24305 \mathrm{E}+03$ & $.92373 \mathrm{E}-06$ & $.39868 \mathrm{E}+03$ & $.24305 \mathrm{E}+03$ \\
1.4 & $.70189 \mathrm{E}-06$ & $.45427 \mathrm{E}+03$ & $.28305 \mathrm{E}+03$ & $.70189 \mathrm{E}-06$ & $.45427 \mathrm{E}+03$ & $.28305 \mathrm{E}+03$ \\
1.6 & $.55322 \mathrm{E}-06$ & $.50772 \mathrm{E}+03$ & $.32305 \mathrm{E}+03$ & $.55322 \mathrm{E}-06$ & $.50772 \mathrm{E}+03$ & $.32305 \mathrm{E}+03$ \\
1.8 & $.44842 \mathrm{E}-06$ & $.55943 \mathrm{E}+03$ & $.36305 \mathrm{E}+03$ & $.44842 \mathrm{E}-06$ & $.55943 \mathrm{E}+03$ & $.36305 \mathrm{E}+03$ \\
2.0 & $.37437 \mathrm{E}-06$ & $.60970 \mathrm{E}+03$ & $.40000 \mathrm{E}+03$ & $.37437 \mathrm{E}-06$ & $.60970 \mathrm{E}+03$ & $.40000 \mathrm{E}+03$ \\
2.2 & $.34651 \mathrm{E}-06$ & $.65872 \mathrm{E}+03$ & $.40000 \mathrm{E}+03$ & $.34651 \mathrm{E}-06$ & $.65872 \mathrm{E}+03$ & $.40000 \mathrm{E}+03$ \\
2.4 & $.32300 \mathrm{E}-06$ & $.70665 \mathrm{E}+03$ & $.40000 \mathrm{E}+03$ & $.32300 \mathrm{E}-06$ & $.70665 \mathrm{E}+03$ & $.40000 \mathrm{E}+03$ \\
2.6 & $.30287 \mathrm{E}-06$ & $.75362 \mathrm{E}+03$ & $.40000 \mathrm{E}+03$ & $.30287 \mathrm{E}-06$ & $.75362 \mathrm{E}+03$ & $.40000 \mathrm{E}+03$ \\
2.3 & $.28541 \mathrm{E}-06$ & $.79973 \mathrm{E}+03$ & $.40000 \mathrm{E}+03$ & $.28541 \mathrm{E}-06$ & $.79973 \mathrm{E}+03$ & $.40000 \mathrm{E}+03$ \\
3.0 & $.27010 \mathrm{E}-06$ & $.84505 \mathrm{E}+03$ & $.40000 \mathrm{E}+03$ & $.27010 \mathrm{E}-06$ & $.84505 \mathrm{E}+03$ & $.40000 \mathrm{E}+03$ \\
\hline
\end{tabular}

Table 10. Same as Table 3, but for case 8

\begin{tabular}{|c|c|c|c|c|c|c|}
\hline $\begin{array}{c}\mathrm{x} \\
(\mathrm{km})\end{array}$ & $\begin{array}{c}\text { Dose (NS) } \\
\left(\mathrm{rem} h \mathrm{r}^{-}\right)\end{array}$ & $\begin{array}{c}\sigma_{\mathrm{y}}(\mathrm{NS}) \\
(\mathrm{m})\end{array}$ & $\begin{array}{c}\sigma_{\mathrm{z}}(\mathrm{NS}) \\
(\mathrm{m})\end{array}$ & $\begin{array}{c}\text { Dose }(\mathrm{AS}) \\
\left.(\mathrm{rem} \mathrm{h})^{-1}\right)\end{array}$ & $\begin{array}{c}\sigma_{\mathrm{y}}(\mathrm{AS}) \\
(\mathrm{m})\end{array}$ & $\begin{array}{c}\sigma_{z}(\mathrm{AS}) \\
(\mathrm{m})\end{array}$ \\
\hline 0.2 & $.43364 \mathrm{E}-05$ & $.62124 \mathrm{E}+02$ & $.27048 \mathrm{E}+02$ & $.43364 \mathrm{E}-05$ & $.62124 \mathrm{E}+02$ & $.27048 \mathrm{E}+02$ \\
0.4 & $.77951 \mathrm{E}-05$ & $.11378 \mathrm{E}+03$ & $.51048 \mathrm{E}+02$ & $.77951 \mathrm{E}-05$ & $.11378 \mathrm{E}+03$ & $.51048 \mathrm{E}+02$ \\
0.6 & $.54511 \mathrm{E}-05$ & $.16234 \mathrm{E}+03$ & $.75048 \mathrm{E}+02$ & $.54511 \mathrm{E}-05$ & $.16234 \mathrm{E}+03$ & $.75048 \mathrm{E}+02$ \\
0.8 & $.36881 \mathrm{E}-05$ & $.20923 \mathrm{E}+03$ & $.99048 \mathrm{E}+02$ & $.36881 \mathrm{E}-05$ & $.20923 \mathrm{E}+03$ & $.99048 \mathrm{E}+02$ \\
1.0 & $.25948 \mathrm{E}-05$ & $.25588 \mathrm{E}+03$ & $.12305 \mathrm{E}+03$ & $.25948 \mathrm{E}-05$ & $.25588 \mathrm{E}+03$ & $.12305 \mathrm{E}+03$ \\
1.2 & $.19229 \mathrm{E}-05$ & $.29977 \mathrm{E}+03$ & $.14705 \mathrm{E}+03$ & $.19229 \mathrm{E}-05$ & $.29977 \mathrm{E}+03$ & $.14705 \mathrm{E}+03$ \\
1.4 & $.14841 \mathrm{E}-05$ & $.34147 \mathrm{E}+03$ & $.17105 \mathrm{E}+03$ & $.14841 \mathrm{E}-05$ & $.34147 \mathrm{E}+03$ & $.17105 \mathrm{E}+03$ \\
1.6 & $.11820 \mathrm{E}-05$ & $.38155 \mathrm{E}+03$ & $.19505 \mathrm{E}+03$ & $.11820 \mathrm{E}-05$ & $.38155 \mathrm{E}+03$ & $.19505 \mathrm{E}+03$ \\
1.8 & $.96508 \mathrm{E}-06$ & $.42033 \mathrm{E}+03$ & $.21905 \mathrm{E}+03$ & $.96508 \mathrm{E}-06$ & $.42033 \mathrm{E}+03$ & $.21905 \mathrm{E}+03$ \\
2.0 & $.80402 \mathrm{E}-06$ & $.45803 \mathrm{E}+03$ & $.24305 \mathrm{E}+03$ & $.80402 \mathrm{E}-06$ & $.45803 \mathrm{E}+03$ & $.24305 \mathrm{E}+03$ \\
2.2 & $.68106 \mathrm{E}-06$ & $.49480 \mathrm{E}+03$ & $.26705 \mathrm{E}+03$ & $.68106 \mathrm{E}-06$ & $.49480 \mathrm{E}+03$ & $.26705 \mathrm{E}+03$ \\
2.4 & $.58497 \mathrm{E}-06$ & $.53075 \mathrm{E}+03$ & $.29105 \mathrm{E}+03$ & $.58497 \mathrm{E}-06$ & $.53075 \mathrm{E}+03$ & $.29105 \mathrm{E}+03$ \\
2.6 & $.50840 \mathrm{E}-06$ & $.56598 \mathrm{E}+03$ & $.31505 \mathrm{E}+03$ & $.50840 \mathrm{E}-06$ & $.56598 \mathrm{E}+03$ & $.31505 \mathrm{E}+03$ \\
2.8 & $.44635 \mathrm{E}-06$ & $.60056 \mathrm{E}+03$ & $.33905 \mathrm{E}+03$ & $.44635 \mathrm{E}-06$ & $.60056 \mathrm{E}+03$ & $.33905 \mathrm{E}+03$ \\
3.0 & $.39533 \mathrm{E}-06$ & $.63455 \mathrm{E}+03$ & $.36305 \mathrm{E}+03$ & $.39533 \mathrm{E}-06$ & $.63455 \mathrm{E}+03$ & $.36305 \mathrm{E}+03$ \\
\hline
\end{tabular}


Table 11. Same as Table 3, but for case 9

\begin{tabular}{|c|c|c|c|c|c|c|}
\hline $\begin{array}{c}\mathrm{x} \\
(\mathrm{km})\end{array}$ & $\begin{array}{c}\text { Dose }(\mathrm{NS}) \\
\left(\mathrm{rem} \mathrm{h} \mathrm{h}^{-1}\right)\end{array}$ & $\begin{array}{c}\sigma_{\mathrm{y}}(\mathrm{NS}) \\
(\mathrm{m})\end{array}$ & $\begin{array}{c}\sigma_{\mathrm{z}}(\mathrm{NS}) \\
(\mathrm{m})\end{array}$ & $\begin{array}{c}\text { Dose }(\mathrm{AS}) \\
(\mathrm{rem} \mathrm{hr})\end{array}$ & $\begin{array}{c}\sigma_{\mathrm{y}}(\mathrm{AS}) \\
(\mathrm{m})\end{array}$ & $\begin{array}{c}\sigma_{\mathrm{z}}(\mathrm{AS}) \\
(\mathrm{m})\end{array}$ \\
\hline 0.2 & $.50609 \mathrm{E}-06$ & $.48996 \mathrm{E}+02$ & $.18737 \mathrm{E}+02$ & $.50609 \mathrm{E}-06$ & $.48996 \mathrm{E}+02$ & $.18737 \mathrm{E}+02$ \\
0.4 & $.60422 \mathrm{E}-05$ & $.89171 \mathrm{E}+02$ & $.33840 \mathrm{E}+02$ & $.60422 \mathrm{E}-05$ & $.89171 \mathrm{E}+02$ & $.33840 \mathrm{E}+02$ \\
0.6 & $.68018 \mathrm{E}-05$ & $.12694 \mathrm{E}+03$ & $.48404 \mathrm{E}+02$ & $.68018 \mathrm{E}-05$ & $.12694 \mathrm{E}+03$ & $.48404 \mathrm{E}+02$ \\
0.8 & $.56208 \mathrm{E}-05$ & $.16341 \mathrm{E}+03$ & $.62471 \mathrm{E}+02$ & $.56208 \mathrm{E}-05$ & $.16341 \mathrm{E}+03$ & $.62471 \mathrm{E}+02$ \\
1.0 & $.44103 \mathrm{E}-05$ & $.19970 \mathrm{E}+03$ & $.76078 \mathrm{E}+02$ & $.44103 \mathrm{E}-05$ & $.19970 \mathrm{E}+03$ & $.76078 \mathrm{E}+02$ \\
1.2 & $.35049 \mathrm{E}-05$ & $.23383 \mathrm{E}+03$ & $.89259 \mathrm{E}+02$ & $.35049 \mathrm{E}-05$ & $.23383 \mathrm{E}+03$ & $.89259 \mathrm{E}+02$ \\
1.4 & $.28440 \mathrm{E}-05$ & $.26626 \mathrm{E}+03$ & $.10204 \mathrm{E}+03$ & $.28440 \mathrm{E}-05$ & $.26626 \mathrm{E}+03$ & $.10204 \mathrm{E}+03$ \\
1.6 & $.23544 \mathrm{E}-05$ & $.29744 \mathrm{E}+03$ & $.11446 \mathrm{E}+03$ & $.23544 \mathrm{E}-05$ & $.29744 \mathrm{E}+03$ & $.11446 \mathrm{E}+03$ \\
1.8 & $.19842 \mathrm{E}-05$ & $.32760 \mathrm{E}+03$ & $.12653 \mathrm{E}+03$ & $.19842 \mathrm{E}-05$ & $.32760 \mathrm{E}+03$ & $.12653 \mathrm{E}+03$ \\
2.0 & $.16982 \mathrm{E}-05$ & $.35693 \mathrm{E}+03$ & $.13827 \mathrm{E}+03$ & $.16982 \mathrm{E}-05$ & $.35693 \mathrm{E}+03$ & $.13827 \mathrm{E}+03$ \\
2.2 & $.14730 \mathrm{E}-05$ & $.38552 \mathrm{E}+03$ & $.14971 \mathrm{E}+03$ & $.14730 \mathrm{E}-05$ & $.38552 \mathrm{E}+03$ & $.14971 \mathrm{E}+03$ \\
2.4 & $.12924 \mathrm{E}-05$ & $.41348 \mathrm{E}+03$ & $.16087 \mathrm{E}+03$ & $.12924 \mathrm{E}-05$ & $.41348 \mathrm{E}+03$ & $.16087 \mathrm{E}+03$ \\
2.6 & $.11453 \mathrm{E}-05$ & $.44088 \mathrm{E}+03$ & $.17176 \mathrm{E}+03$ & $.11453 \mathrm{E}-05$ & $.44088 \mathrm{E}+03$ & $.17176 \mathrm{E}+03$ \\
2.8 & $.10238 \mathrm{E}-05$ & $.46778 \mathrm{E}+03$ & $.18239 \mathrm{E}+03$ & $.10238 \mathrm{E}-05$ & $.46778 \mathrm{E}+03$ & $.18239 \mathrm{E}+0$ \\
3.0 & $.92217 \mathrm{E}-06$ & $.49422 \mathrm{E}+03$ & $.19278 \mathrm{E}+03$ & $.92217 \mathrm{E}-06$ & $.49422 \mathrm{E}+03$ & $.19278 \mathrm{E}+0$ \\
\hline
\end{tabular}

Table 12. Same as Table 3, but for case 10

\begin{tabular}{|c|c|c|c|c|c|c|}
\hline $\begin{array}{c}\mathrm{x} \\
(\mathrm{km}) \\
\end{array}$ & $\begin{array}{l}\text { Dose (NS) } \\
\left(\text { rem } \mathrm{hr}^{-1}\right)\end{array}$ & $\begin{array}{c}\sigma_{y}(\mathrm{NS}) \\
(\mathrm{m})\end{array}$ & $\begin{array}{c}\sigma_{\mathrm{z}}(\mathrm{NS}) \\
(\mathrm{m})\end{array}$ & $\begin{array}{l}\text { Dose (AS) } \\
(\text { rem hr-1) }\end{array}$ & $\begin{array}{c}\sigma_{y}(\mathrm{AS}) \\
(\mathrm{m})\end{array}$ & $\begin{array}{c}\sigma_{\mathrm{z}}(\mathrm{AS}) \\
(\mathrm{m})\end{array}$ \\
\hline 0.2 & $.00000 \mathrm{E}+00$ & $.22740 \mathrm{E}+02$ & $.87084 \mathrm{E}+01$ & $.00000 \mathrm{E}+00$ & $.22740 \mathrm{E}+02$ & $.87084 \mathrm{E}+01$ \\
\hline 0.4 & $.92193 \mathrm{E}-08$ & $.39958 \mathrm{E}+02$ & $.13762 E+02$ & $.92193 \mathrm{E}-08$ & $.39958 \mathrm{E}+02$ & $.13762 E+02$ \\
\hline 0.6 & $.35052 \mathrm{E}-06$ & $.56144 \mathrm{E}+02$ & $.18302 E+02$ & $.35052 \mathrm{E}-06$ & $.56144 \mathrm{E}+02$ & $18302 \mathrm{E}+02$ \\
\hline 0.8 & $.14172 \mathrm{E}-05$ & $.71774 \mathrm{E}+02$ & $.22403 E+02$ & $.14172 \mathrm{E}-05$ & $.71774 \mathrm{E}+02$ & $.22403 E+02$ \\
\hline 1.0 & 07E-05 & $.87325 E+02$ & $.26125 \mathrm{E}+02$ & $.26607 \mathrm{E}-05$ & $.87325 E+02$ & $26125 E+02$ \\
\hline 1.2 & $.36385 \mathrm{E}-05$ & $.10196 \mathrm{E}+03$ & $.29519 E+02$ & $.36385 E-05$ & $.10196 \mathrm{E}+03$ & $29519 E+02$ \\
\hline 1.4 & $.42652 \mathrm{E}-05$ & $.11585 \mathrm{E}+03$ & $.32625 E+02$ & $.42652 \mathrm{E}-05$ & $.11585 E+03$ & $.32625 E+02$ \\
\hline 1.6 & $.46047 \mathrm{E}-05$ & $.12922 \mathrm{E}+03$ & $.35480 \mathrm{E}+02$ & $.46047 \mathrm{E}-05$ & $.12922 \mathrm{E}+03$ & $.35480 \mathrm{E}+02$ \\
\hline 1.8 & $.47446 \mathrm{E}-05$ & $.14214 E+03$ & $.38113 E+02$ & $.47446 \mathrm{E}-05$ & $.14214 \mathrm{E}+03$ & $.38113 E+02$ \\
\hline .0 & $.47559 \mathrm{E}-05$ & $.15471 E+03$ & $.40548 \mathrm{E}+02$ & $.47559 \mathrm{E}-05$ & $.15471 E+03$ & $.40548 E+02$ \\
\hline 2.2 & $.46882 \mathrm{E}-05$ & $.16697 E+03$ & $.42807 E+02$ & $.46882 \mathrm{E}-05$ & $.16697 E+03$ & $.42807 E+02$ \\
\hline 2.4 & $.45745 \mathrm{E}-05$ & $.17895 E+03$ & $.44909 E+02$ & $.45745 \mathrm{E}-05$ & $.17895 \mathrm{E}+03$ & $.44908 E+02$ \\
\hline 2.6 & $.44356 \mathrm{E}-05$ & $.19069 E+03$ & $.46868 E+02$ & $.44356 \mathrm{E}-05$ & $.19069 \mathrm{E}+03$ & $.46868 \mathrm{E}+02$ \\
\hline & $.42848 \mathrm{E}-05$ & $.20222 E+03$ & $.48700 E+02$ & $.42848 E-05$ & $.20222 \mathrm{E}+03$ & $.48700 E+02$ \\
\hline 3.0 & .41 & $.21355 E+03$ & $.50416 E+02$ & $.41303 \mathrm{E}-05$ & $.21355 E+03$ & $.50416 \mathrm{E}+02$ \\
\hline
\end{tabular}


Table 13. Same as Table 3, but for case 11

\begin{tabular}{|c|c|c|c|c|c|c|}
\hline $\begin{array}{c}\mathrm{x} \\
(\mathrm{km})\end{array}$ & $\begin{array}{c}\text { Dose }(\mathrm{NS}) \\
\left(\mathrm{rem} \mathrm{h} \mathrm{r}^{-1}\right)\end{array}$ & $\begin{array}{c}\sigma_{\mathrm{y}}(\mathrm{NS}) \\
(\mathrm{m})\end{array}$ & $\begin{array}{c}\sigma_{\mathrm{z}}(\mathrm{NS}) \\
(\mathrm{m})\end{array}$ & $\begin{array}{c}\text { Dose }(\mathrm{AS}) \\
\left.(\mathrm{rem} \mathrm{h})^{-1}\right)\end{array}$ & $\begin{array}{c}\sigma_{\mathrm{y}}(\mathrm{AS}) \\
(\mathrm{m})\end{array}$ & $\begin{array}{c}\sigma_{\mathrm{z}}(\mathrm{AS}) \\
(\mathrm{m})\end{array}$ \\
\hline 0.2 & $.00000 \mathrm{E}+00$ & $.96120 \mathrm{E}+01$ & $.60669 \mathrm{E}+01$ & $.00000 \mathrm{E}+00$ & $.96120 \mathrm{E}+01$ & $.60669 \mathrm{E}+01$ \\
0.4 & $.00000 \mathrm{E}+00$ & $.15351 \mathrm{E}+02$ & $.87623 \mathrm{E}+01$ & $.00000 \mathrm{E}+00$ & $.15351 \mathrm{E}+02$ & $.87623 \mathrm{E}+01$ \\
0.6 & $.14066 \mathrm{E}-09$ & $.20747 \mathrm{E}+02$ & $.11184 \mathrm{E}+02$ & $.14066 \mathrm{E}-09$ & $.20747 \mathrm{E}+02$ & $.11184 \mathrm{E}+02$ \\
0.8 & $.81528 \mathrm{E}-08$ & $.25957 \mathrm{E}+02$ & $.13371 \mathrm{E}+02$ & $.81528 \mathrm{E}-08$ & $.25957 \mathrm{E}+02$ & $.13371 \mathrm{E}+02$ \\
1.0 & $.73067 \mathrm{E}-07$ & $.31140 \mathrm{E}+02$ & $.15356 \mathrm{E}+02$ & $.73067 \mathrm{E}-07$ & $.31140 \mathrm{E}+02$ & $.15356 \mathrm{E}+02$ \\
1.2 & $.27276 \mathrm{E}-06$ & $.36017 \mathrm{E}+02$ & $.17166 \mathrm{E}+02$ & $.27276 \mathrm{E}-06$ & $.36017 \mathrm{E}+02$ & $.17166 \mathrm{E}+02$ \\
1.4 & $.63701 \mathrm{E}-06$ & $.40650 \mathrm{E}+02$ & $.18823 \mathrm{E}+02$ & $.63701 \mathrm{E}-06$ & $.40650 \mathrm{E}+02$ & $.18823 \mathrm{E}+02$ \\
1.6 & $.11308 \mathrm{E}-05$ & $.45104 \mathrm{E}+02$ & $.20345 \mathrm{E}+02$ & $.11308 \mathrm{E}-05$ & $.45104 \mathrm{E}+02$ & $.20345 \mathrm{E}+02$ \\
1.8 & $.16917 \mathrm{E}-05$ & $.49413 \mathrm{E}+02$ & $.21749 \mathrm{E}+02$ & $.16917 \mathrm{E}-05$ & $.49413 \mathrm{E}+02$ & $.21749 \mathrm{E}+02$ \\
2.0 & $.22627 \mathrm{E}-05$ & $.53602 \mathrm{E}+02$ & $.23048 \mathrm{E}+02$ & $.22627 \mathrm{E}-05$ & $.53602 \mathrm{E}+02$ & $.23048 \mathrm{E}+02$ \\
2.2 & $.28040 \mathrm{E}-05$ & $.57687 \mathrm{E}+02$ & $.24253 \mathrm{E}+02$ & $.28040 \mathrm{E}-05$ & $.57687 \mathrm{E}+02$ & $.24253 \mathrm{E}+02$ \\
2.4 & $.32931 \mathrm{E}-05$ & $.61682 \mathrm{E}+02$ & $.25374 \mathrm{E}+02$ & $.32931 \mathrm{E}-05$ & $.61682 \mathrm{E}+02$ & $.25374 \mathrm{E}+02$ \\
2.6 & $.37202 \mathrm{E}-05$ & $.65596 \mathrm{E}+02$ & $.26419 \mathrm{E}+02$ & $.37202 \mathrm{E}-05$ & $.65596 \mathrm{E}+02$ & $.26419 \mathrm{E}+02$ \\
2.8 & $.40838 \mathrm{E}-05$ & $.69438 \mathrm{E}+02$ & $.27396 \mathrm{E}+02$ & $.40838 \mathrm{E}-05$ & $.69438 \mathrm{E}+02$ & $.27396 \mathrm{E}+02$ \\
3.0 & $.43872 \mathrm{E}-05$ & $.73215 \mathrm{E}+02$ & $.28311 \mathrm{E}+02$ & $.43872 \mathrm{E}-05$ & $.73215 \mathrm{E}+02$ & $.28311 \mathrm{E}+02$ \\
\hline
\end{tabular}

Table 14. Same as Table 3, but for case 12

\begin{tabular}{|c|c|c|c|c|c|c|}
\hline $\begin{array}{c}\mathrm{x} \\
(\mathrm{km})\end{array}$ & $\begin{array}{c}\text { Dose }(\mathrm{NS}) \\
(\mathrm{rem} \mathrm{hr})\end{array}$ & $\begin{array}{c}\sigma_{\mathrm{y}}(\mathrm{NS}) \\
(\mathrm{m})\end{array}$ & $\begin{array}{c}\sigma_{\mathrm{z}}(\mathrm{NS}) \\
(\mathrm{m})\end{array}$ & $\begin{array}{c}\text { Dose }(\mathrm{AS}) \\
(\mathrm{rem} \mathrm{h})\end{array}$ & $\begin{array}{c}\sigma_{\mathrm{y}}(\mathrm{AS}) \\
(\mathrm{m})\end{array}$ & $\begin{array}{c}\sigma_{\mathrm{z}}(\mathrm{AS}) \\
(\mathrm{m})\end{array}$ \\
\hline 0.2 & $.59269 \mathrm{E}-07$ & $.35868 \mathrm{E}+02$ & $.13573 \mathrm{E}+02$ & $.59269 \mathrm{E}-07$ & $.35868 \mathrm{E}+02$ & $.13573 \mathrm{E}+02$ \\
0.4 & $.10563 \mathrm{E}-04$ & $.64565 \mathrm{E}+02$ & $.22022 \mathrm{E}+02$ & $.10563 \mathrm{E}-04$ & $.64565 \mathrm{E}+02$ & $.22022 \mathrm{E}+02$ \\
0.6 & $.29203 \mathrm{E}-04$ & $.91542 \mathrm{E}+02$ & $.29165 \mathrm{E}+02$ & $.29203 \mathrm{E}-04$ & $.91542 \mathrm{E}+02$ & $.29165 \mathrm{E}+02$ \\
0.8 & $.37801 \mathrm{E}-04$ & $.11759 \mathrm{E}+03$ & $.35410 \mathrm{E}+02$ & $.37801 \mathrm{E}-04$ & $.11759 \mathrm{E}+03$ & $.35410 \mathrm{E}+02$ \\
1.0 & $.38977 \mathrm{E}-04$ & $.14351 \mathrm{E}+03$ & $.40995 \mathrm{E}+02$ & $.38977 \mathrm{E}-04$ & $.14351 \mathrm{E}+03$ & $.40995 \mathrm{E}+02$ \\
1.2 & $.37323 \mathrm{E}-04$ & $.16789 \mathrm{E}+03$ & $.46076 \mathrm{E}+02$ & $.37323 \mathrm{E}-04$ & $.16789 \mathrm{E}+03$ & $.46076 \mathrm{E}+02$ \\
1.4 & $.34729 \mathrm{E}-04$ & $.19106 \mathrm{E}+03$ & $.50757 \mathrm{E}+02$ & $.34729 \mathrm{E}-04$ & $.19106 \mathrm{E}+03$ & $.50757 \mathrm{E}+02$ \\
1.6 & $.31960 \mathrm{E}-04$ & $.21333 \mathrm{E}+03$ & $.55111 \mathrm{E}+02$ & $.31960 \mathrm{E}-04$ & $.21333 \mathrm{E}+03$ & $.55111 \mathrm{E}+02$ \\
1.8 & $.29320 \mathrm{E}-04$ & $.23487 \mathrm{E}+03$ & $.59195 \mathrm{E}+02$ & $.29320 \mathrm{E}-04$ & $.23487 \mathrm{E}+03$ & $.59195 \mathrm{E}+02$ \\
2.0 & $.26914 \mathrm{E}-04$ & $.25582 \mathrm{E}+03$ & $.63048 \mathrm{E}+02$ & $.26914 \mathrm{E}-04$ & $.25582 \mathrm{E}+03$ & $.63048 \mathrm{E}+02$ \\
2.2 & $.24761 \mathrm{E}-04$ & $.27624 \mathrm{E}+03$ & $.66704 \mathrm{E}+02$ & $.24761 \mathrm{E}-04$ & $.27624 \mathrm{E}+03$ & $.66704 \mathrm{E}+02$ \\
2.4 & $.22851 \mathrm{E}-04$ & $.29622 \mathrm{E}+03$ & $.70188 \mathrm{E}+02$ & $.22851 \mathrm{E}-04$ & $.29622 \mathrm{E}+03$ & $.70188 \mathrm{E}+02$ \\
2.6 & $.21158 \mathrm{E}-04$ & $.31579 \mathrm{E}+03$ & $.73522 \mathrm{E}+02$ & $.21158 \mathrm{E}-04$ & $.31579 \mathrm{E}+03$ & $.73522 \mathrm{E}+02$ \\
2.8 & $.19657 \mathrm{E}-04$ & $.33500 \mathrm{E}+03$ & $.76721 \mathrm{E}+02$ & $.19657 \mathrm{E}-04$ & $.33500 \mathrm{E}+03$ & $.76721 \mathrm{E}+02$ \\
3.0 & $.18323 \mathrm{E}-04$ & $.35388 \mathrm{E}+03$ & $.79800 \mathrm{E}+02$ & $.18323 \mathrm{E}-04$ & $.35388 \mathrm{E}+03$ & $.79800 \mathrm{E}+02$ \\
\hline
\end{tabular}


Table 15. Same as Table 3, but for case 13

\begin{tabular}{|c|c|c|c|c|c|c|}
\hline $\begin{array}{c}\mathrm{x} \\
(\mathrm{km})\end{array}$ & $\begin{array}{c}\text { Dose }(\mathrm{NS}) \\
(\mathrm{rem} \mathrm{hr})\end{array}$ & $\begin{array}{c}\sigma_{\mathrm{y}}(\mathrm{NS}) \\
(\mathrm{m})\end{array}$ & $\begin{array}{c}\sigma_{\mathrm{z}}(\mathrm{NS}) \\
(\mathrm{m})\end{array}$ & $\begin{array}{c}\text { Dose }(\mathrm{AS}) \\
(\mathrm{rem} \mathrm{hr})\end{array}$ & $\begin{array}{c}\sigma_{\mathrm{y}}(\mathrm{AS}) \\
(\mathrm{m})\end{array}$ & $\begin{array}{c}\sigma_{\mathrm{z}}(\mathrm{AS}) \\
(\mathrm{m})\end{array}$ \\
\hline 0.2 & $.19756 \mathrm{E}-07$ & $.35868 \mathrm{E}+02$ & $.13573 \mathrm{E}+02$ & $.19756 \mathrm{E}-07$ & $.35868 \mathrm{E}+02$ & $.13573 \mathrm{E}+02$ \\
0.4 & $.35209 \mathrm{E}-05$ & $.64565 \mathrm{E}+02$ & $.22022 \mathrm{E}+02$ & $.35209 \mathrm{E}-05$ & $.64565 \mathrm{E}+02$ & $.22022 \mathrm{E}+02$ \\
0.6 & $.97342 \mathrm{E}-05$ & $.91542 \mathrm{E}+02$ & $.29165 \mathrm{E}+02$ & $.97342 \mathrm{E}-05$ & $.91542 \mathrm{E}+02$ & $.29165 \mathrm{E}+02$ \\
0.8 & $.12600 \mathrm{E}-04$ & $.11759 \mathrm{E}+03$ & $.35410 \mathrm{E}+02$ & $.12600 \mathrm{E}-04$ & $.11759 \mathrm{E}+03$ & $.35410 \mathrm{E}+02$ \\
1.0 & $.12992 \mathrm{E}-04$ & $.14351 \mathrm{E}+03$ & $.40995 \mathrm{E}+02$ & $.12992 \mathrm{E}-04$ & $.14351 \mathrm{E}+03$ & $.0995 \mathrm{E}+02$ \\
1.2 & $.12441 \mathrm{E}-04$ & $.16789 \mathrm{E}+03$ & $.46076 \mathrm{E}+02$ & $.12441 \mathrm{E}-04$ & $.16789 \mathrm{E}+03$ & $.46076 \mathrm{E}+02$ \\
1.4 & $.11576 \mathrm{E}-04$ & $.19106 \mathrm{E}+03$ & $.50757 \mathrm{E}+02$ & $.11576 \mathrm{E}-04$ & $.19106 \mathrm{E}+03$ & $.50757 \mathrm{E}+02$ \\
1.6 & $.10653 \mathrm{E}-04$ & $.21333 \mathrm{E}+03$ & $.55111 \mathrm{E}+02$ & $.10653 \mathrm{E}-04$ & $.21333 \mathrm{E}+03$ & $.55111 \mathrm{E}+02$ \\
1.8 & $.97734 \mathrm{E}-05$ & $.23487 \mathrm{E}+03$ & $.59195 \mathrm{E}+02$ & $.97734 \mathrm{E}-05$ & $.23487 \mathrm{E}+03$ & $.59195 \mathrm{E}+02$ \\
2.0 & $.89712 \mathrm{E}-05$ & $.25582 \mathrm{E}+03$ & $.63048 \mathrm{E}+02$ & $.89712 \mathrm{E}-05$ & $.25582 \mathrm{E}+03$ & $.63048 \mathrm{E}+02$ \\
2.2 & $.82538 \mathrm{E}-05$ & $.27624 \mathrm{E}+03$ & $.66704 \mathrm{E}+02$ & $.82538 \mathrm{E}-05$ & $.27624 \mathrm{E}+03$ & $.66704 \mathrm{E}+02$ \\
2.4 & $.76170 \mathrm{E}-05$ & $.29622 \mathrm{E}+03$ & $.70188 \mathrm{E}+02$ & $.76170 \mathrm{E}-05$ & $.29622 \mathrm{E}+03$ & $.70188 \mathrm{E}+02$ \\
2.6 & $.70528 \mathrm{E}-05$ & $.31579 \mathrm{E}+03$ & $.73522 \mathrm{E}+02$ & $.70528 \mathrm{E}-05$ & $.31579 \mathrm{E}+03$ & $.73522 \mathrm{E}+02$ \\
2.8 & $.65525 \mathrm{E}-05$ & $.33500 \mathrm{E}+03$ & $.76721 \mathrm{E}+02$ & $.65525 \mathrm{E}-05$ & $.33500 \mathrm{E}+03$ & $.76721 \mathrm{E}+02$ \\
3.0 & $.61076 \mathrm{E}-05$ & $.35388 \mathrm{E}+03$ & $.79800 \mathrm{E}+02$ & $.61076 \mathrm{E}-05$ & $.35388 \mathrm{E}+03$ & $.79800 \mathrm{E}+02$ \\
\hline
\end{tabular}

Table 16. Same as Table 3, but for case 14

\begin{tabular}{|c|c|c|c|c|c|c|}
\hline $\begin{array}{c}\mathrm{x} \\
(\mathrm{km})\end{array}$ & $\begin{array}{c}\text { Dose (NS) } \\
\left(\mathrm{rem} \mathrm{h} \mathrm{hr}^{-1}\right)\end{array}$ & $\begin{array}{c}\sigma_{\mathrm{y}}(\mathrm{NS}) \\
(\mathrm{m})\end{array}$ & $\begin{array}{c}\sigma_{\mathrm{z}}(\mathrm{NS}) \\
(\mathrm{m})\end{array}$ & $\begin{array}{c}\text { Dose }(\mathrm{AS}) \\
(\mathrm{rem} \mathrm{hr})\end{array}$ & $\begin{array}{c}\sigma_{\mathrm{y}}(\mathrm{AS}) \\
(\mathrm{m})\end{array}$ & $\begin{array}{c}\sigma_{\mathrm{z}}(\mathrm{AS}) \\
(\mathrm{m})\end{array}$ \\
\hline 0.2 & $.11854 \mathrm{E}-07$ & $.35868 \mathrm{E}+02$ & $.13573 \mathrm{E}+02$ & $.11854 \mathrm{E}-07$ & $.35868 \mathrm{E}+02$ & $.13573 \mathrm{E}+02$ \\
0.4 & $.21125 \mathrm{E}-05$ & $.64565 \mathrm{E}+02$ & $.22022 \mathrm{E}+02$ & $.21125 \mathrm{E}-05$ & $.64565 \mathrm{E}+02$ & $.22022 \mathrm{E}+02$ \\
0.6 & $.58405 \mathrm{E}-05$ & $.91542 \mathrm{E}+02$ & $.29165 \mathrm{E}+02$ & $.58405 \mathrm{E}-05$ & $.91542 \mathrm{E}+02$ & $.29165 \mathrm{E}+02$ \\
0.8 & $.75602 \mathrm{E}-05$ & $.11759 \mathrm{E}+03$ & $.35410 \mathrm{E}+02$ & $.75602 \mathrm{E}-05$ & $.11759 \mathrm{E}+03$ & $.35410 \mathrm{E}+02$ \\
1.0 & $.77955 \mathrm{E}-05$ & $.14351 \mathrm{E}+03$ & $.40995 \mathrm{E}+02$ & $.77955 \mathrm{E}-05$ & $.14351 \mathrm{E}+03$ & $.40995 \mathrm{E}+02$ \\
1.2 & $.74645 \mathrm{E}-05$ & $.16789 \mathrm{E}+03$ & $.46076 \mathrm{E}+02$ & $.74645 \mathrm{E}-05$ & $.16789 \mathrm{E}+03$ & $.46076 \mathrm{E}+02$ \\
1.4 & $.69458 \mathrm{E}-05$ & $.19106 \mathrm{E}+03$ & $.50757 \mathrm{E}+02$ & $.69458 \mathrm{E}-05$ & $.19106 \mathrm{E}+03$ & $.50757 \mathrm{E}+02$ \\
1.6 & $.63920 \mathrm{E}-05$ & $.21333 \mathrm{E}+03$ & $.55111 \mathrm{E}+02$ & $.63920 \mathrm{E}-05$ & $.21333 \mathrm{E}+03$ & $.55111 \mathrm{E}+02$ \\
1.8 & $.58641 \mathrm{E}-05$ & $.23487 \mathrm{E}+03$ & $.59195 \mathrm{E}+02$ & $.58641 \mathrm{E}-05$ & $.23487 \mathrm{E}+03$ & $.59195 \mathrm{E}+02$ \\
2.0 & $.53827 \mathrm{E}-05$ & $.25582 \mathrm{E}+03$ & $.63048 \mathrm{E}+02$ & $.53827 \mathrm{E}-05$ & $.25582 \mathrm{E}+03$ & $.63048 \mathrm{E}+02$ \\
2.2 & $.49523 \mathrm{E}-05$ & $.27624 \mathrm{E}+03$ & $.66704 \mathrm{E}+02$ & $.49523 \mathrm{E}-05$ & $.27624 \mathrm{E}+03$ & $.66704 \mathrm{E}+02$ \\
2.4 & $.45702 \mathrm{E}-05$ & $.29622 \mathrm{E}+03$ & $.70188 \mathrm{E}+02$ & $.45702 \mathrm{E}-05$ & $.29622 \mathrm{E}+03$ & $.70188 \mathrm{E}+02$ \\
2.6 & $.42317 \mathrm{E}-05$ & $.31579 \mathrm{E}+03$ & $.73522 \mathrm{E}+02$ & $.42317 \mathrm{E}-05$ & $.31579 \mathrm{E}+03$ & $.73522 \mathrm{E}+02$ \\
2.8 & $.39315 \mathrm{E}-05$ & $.33500 \mathrm{E}+03$ & $.76721 \mathrm{E}+02$ & $.39315 \mathrm{E}-05$ & $.33500 \mathrm{E}+03$ & $.76721 \mathrm{E}+02$ \\
3.0 & $.36646 \mathrm{E}-05$ & $.35388 \mathrm{E}+03$ & $.79800 \mathrm{E}+02$ & $.36646 \mathrm{E}-05$ & $.35388 \mathrm{E}+03$ & $.79800 \mathrm{E}+02$ \\
\hline
\end{tabular}


Table 17. Same as Table 3, but for case 15

\begin{tabular}{|c|c|c|c|c|c|c|}
\hline $\begin{array}{c}\mathrm{x} \\
(\mathrm{km})\end{array}$ & $\begin{array}{c}\text { Dose (NS) } \\
\left(\mathrm{rem} \mathrm{h} \mathrm{h}^{-1}\right)\end{array}$ & $\begin{array}{c}\sigma_{\mathrm{y}}(\mathrm{NS}) \\
(\mathrm{m})\end{array}$ & $\begin{array}{c}\sigma_{\mathrm{z}}(\mathrm{NS}) \\
(\mathrm{m})\end{array}$ & $\begin{array}{c}\text { Dose }(\mathrm{AS}) \\
\left(\mathrm{rem} \mathrm{h} \mathrm{r}^{-1}\right)\end{array}$ & $\begin{array}{c}\sigma_{\mathrm{y}}(\mathrm{AS}) \\
(\mathrm{m})\end{array}$ & $\begin{array}{c}\sigma_{\mathrm{z}}(\mathrm{AS}) \\
(\mathrm{m})\end{array}$ \\
\hline 0.2 & $.59269 \mathrm{E}-08$ & $.35868 \mathrm{E}+02$ & $.13573 \mathrm{E}+02$ & $.59269 \mathrm{E}-08$ & $.35868 \mathrm{E}+02$ & $.13573 \mathrm{E}+02$ \\
0.4 & $.10563 \mathrm{E}-05$ & $.64565 \mathrm{E}+02$ & $.22022 \mathrm{E}+02$ & $.10563 \mathrm{E}-05$ & $.64565 \mathrm{E}+02$ & $.22022 \mathrm{E}+02$ \\
0.6 & $.29203 \mathrm{E}-05$ & $.91542 \mathrm{E}+02$ & $.29165 \mathrm{E}+02$ & $.29203 \mathrm{E}-05$ & $.91542 \mathrm{E}+02$ & $.29165 \mathrm{E}+02$ \\
0.8 & $.37801 \mathrm{E}-05$ & $.11759 \mathrm{E}+03$ & $.35410 \mathrm{E}+02$ & $.37801 \mathrm{E}-05$ & $.11759 \mathrm{E}+03$ & $.35410 \mathrm{E}+02$ \\
1.0 & $.38977 \mathrm{E}-05$ & $.14351 \mathrm{E}+03$ & $.40995 \mathrm{E}+02$ & $.38977 \mathrm{E}-05$ & $.14351 \mathrm{E}+03$ & $.40995 \mathrm{E}+02$ \\
1.2 & $.37323 \mathrm{E}-05$ & $.16789 \mathrm{E}+03$ & $.46076 \mathrm{E}+02$ & $.37323 \mathrm{E}-05$ & $.16789 \mathrm{E}+03$ & $.46076 \mathrm{E}+02$ \\
1.4 & $.34729 \mathrm{E}-05$ & $.19106 \mathrm{E}+03$ & $.50757 \mathrm{E}+02$ & $.34729 \mathrm{E}-05$ & $.19106 \mathrm{E}+03$ & $.50757 \mathrm{E}+02$ \\
1.6 & $.31960 \mathrm{E}-05$ & $.21333 \mathrm{E}+03$ & $.55111 \mathrm{E}+02$ & $.31960 \mathrm{E}-05$ & $.21333 \mathrm{E}+03$ & $.55111 \mathrm{E}+02$ \\
1.8 & $.29320 \mathrm{E}-05$ & $.23487 \mathrm{E}+03$ & $.59195 \mathrm{E}+02$ & $.29320 \mathrm{E}-05$ & $.23487 \mathrm{E}+03$ & $.59195 \mathrm{E}+02$ \\
2.0 & $.26914 \mathrm{E}-05$ & $.25582 \mathrm{E}+03$ & $.63048 \mathrm{E}+02$ & $.26914 \mathrm{E}-05$ & $.25582 \mathrm{E}+03$ & $.63048 \mathrm{E}+02$ \\
2.2 & $.24761 \mathrm{E}-05$ & $.27624 \mathrm{E}+03$ & $.66704 \mathrm{E}+02$ & $.24761 \mathrm{E}-05$ & $.27624 \mathrm{E}+03$ & $.66704 \mathrm{E}+02$ \\
2.4 & $.22851 \mathrm{E}-05$ & $.29622 \mathrm{E}+03$ & $.70188 \mathrm{E}+02$ & $.22851 \mathrm{E}-05$ & $.29622 \mathrm{E}+03$ & $.70188 \mathrm{E}+02$ \\
2.6 & $.21158 \mathrm{E}-05$ & $.31579 \mathrm{E}+03$ & $.73522 \mathrm{E}+02$ & $.21158 \mathrm{E}-05$ & $.31579 \mathrm{E}+03$ & $.73522 \mathrm{E}+02$ \\
2.8 & $.19657 \mathrm{E}-05$ & $.33500 \mathrm{E}+03$ & $.76721 \mathrm{E}+02$ & $.19657 \mathrm{E}-05$ & $.33500 \mathrm{E}+03$ & $.76721 \mathrm{E}+02$ \\
3.0 & $.18323 \mathrm{E}-05$ & $.35388 \mathrm{E}+03$ & $.79800 \mathrm{E}+02$ & $.18323 \mathrm{E}-05$ & $.35388 \mathrm{E}+03$ & $.79800 \mathrm{E}+02$ \\
\hline
\end{tabular}


Table 18. Comparison of the analytic solution (AS), Eq. (6), and the numerical results (NS) calculated by PUFF/PLU for a plume using the input parameters given for case 1 (default case) listed in Tables 1 and 2

\begin{tabular}{|r|c|c|c|c|c|c|}
\hline $\begin{array}{c}\mathrm{x} \\
(\mathrm{km})\end{array}$ & $\begin{array}{c}\text { Dose }(\mathrm{NS}) \\
(\mathrm{rem})\end{array}$ & $\begin{array}{c}\sigma_{\mathrm{y}}(\mathrm{NS}) \\
(\mathrm{m})\end{array}$ & $\begin{array}{c}\sigma_{\mathrm{z}}(\mathrm{NS}) \\
(\mathrm{m})\end{array}$ & $\begin{array}{c}\text { Dose }(\mathrm{AS}) \\
(\mathrm{rem})\end{array}$ & $\begin{array}{c}\sigma_{\mathrm{y}}(\mathrm{AS}) \\
(\mathrm{m})\end{array}$ & $\begin{array}{c}\sigma_{\mathrm{z}}(\mathrm{AS}) \\
(\mathrm{m})\end{array}$ \\
\hline 1.8 & $0.4687 \mathrm{E}-05$ & $0.1954 \mathrm{E}+03$ & $0.5919 \mathrm{E}+02$ & $0.4697 \mathrm{E}-05$ & $0.1955 \mathrm{E}+03$ & $0.5919 \mathrm{E}+02$ \\
3.6 & $0.2513 \mathrm{E}-05$ & $0.3269 \mathrm{E}+03$ & $0.8843 \mathrm{E}+02$ & $0.2518 \mathrm{E}-05$ & $0.3271 \mathrm{E}+03$ & $0.8843 \mathrm{E}+02$ \\
5.4 & $0.1610 \mathrm{E}-05$ & $0.4450 \mathrm{E}+03$ & $0.1105 \mathrm{E}+03$ & $0.1613 \mathrm{E}-05$ & $0.4452 \mathrm{E}+03$ & $0.1105 \mathrm{E}+03$ \\
7.2 & $0.1153 \mathrm{E}-05$ & $0.5548 \mathrm{E}+03$ & $0.1288 \mathrm{E}+03$ & $0.1155 \mathrm{E}-05$ & $0.5551 \mathrm{E}+03$ & $0.1288 \mathrm{E}+03$ \\
9.0 & $0.8839 \mathrm{E}-06$ & $0.6589 \mathrm{E}+03$ & $0.1449 \mathrm{E}+03$ & $0.8853 \mathrm{E}-06$ & $0.6592 \mathrm{E}+03$ & $0.1449 \mathrm{E}+03$ \\
10.8 & $0.7162 \mathrm{E}-06$ & $0.7509 \mathrm{E}+03$ & $0.1593 \mathrm{E}+03$ & $0.7174 \mathrm{E}-06$ & $0.7512 \mathrm{E}+03$ & $0.1593 \mathrm{E}+03$ \\
12.6 & $0.6191 \mathrm{E}-06$ & $0.8108 \mathrm{E}+03$ & $0.1725 \mathrm{E}+03$ & $0.6201 \mathrm{E}-06$ & $0.8112 \mathrm{E}+03$ & $0.1725 \mathrm{E}+03$ \\
14.4 & $0.5452 \mathrm{E}-06$ & $0.8665 \mathrm{E}+03$ & $0.1848 \mathrm{E}+03$ & $0.5460 \mathrm{E}-06$ & $0.8670 \mathrm{E}+03$ & $0.1848 \mathrm{E}+03$ \\
16.2 & $0.4870 \mathrm{E}-06$ & $0.9189 \mathrm{E}+03$ & $0.1963 \mathrm{E}+03$ & $0.4877 \mathrm{E}-06$ & $0.9194 \mathrm{E}+03$ & $0.1963 \mathrm{E}+03$ \\
18.0 & $0.4400 \mathrm{E}-06$ & $0.9685 \mathrm{E}+03$ & $0.2071 \mathrm{E}+03$ & $0.4407 \mathrm{E}-06$ & $0.9690 \mathrm{E}+03$ & $0.2071 \mathrm{E}+03$ \\
19.8 & $0.4013 \mathrm{E}-06$ & $0.1016 \mathrm{E}+04$ & $0.2175 \mathrm{E}+03$ & $0.4019 \mathrm{E}-06$ & $0.1016 \mathrm{E}+04$ & $0.2175 \mathrm{E}+03$ \\
21.6 & $0.3689 \mathrm{E}-06$ & $0.1061 \mathrm{E}+04$ & $0.2273 \mathrm{E}+03$ & $0.3694 \mathrm{E}-06$ & $0.1061 \mathrm{E}+04$ & $0.2273 \mathrm{E}+03$ \\
23.4 & $0.3413 \mathrm{E}-06$ & $0.1104 \mathrm{E}+04$ & $0.2367 \mathrm{E}+03$ & $0.3418 \mathrm{E}-06$ & $0.1104 \mathrm{E}+04$ & $0.2367 \mathrm{E}+03$ \\
25.2 & $0.3175 \mathrm{E}-06$ & $0.1145 \mathrm{E}+04$ & $0.2458 \mathrm{E}+03$ & $0.3180 \mathrm{E}-06$ & $0.1146 \mathrm{E}+04$ & $0.2458 \mathrm{E}+03$ \\
27.0 & $0.2969 \mathrm{E}-06$ & $0.1185 \mathrm{E}+04$ & $0.2545 \mathrm{E}+03$ & $0.2973 \mathrm{E}-06$ & $0.1186 \mathrm{E}+04$ & $0.2545 \mathrm{E}+03$ \\
28.8 & $0.2787 \mathrm{E}-06$ & $0.1224 \mathrm{E}+04$ & $0.2630 \mathrm{E}+03$ & $0.2792 \mathrm{E}-06$ & $0.1225 \mathrm{E}+04$ & $0.2630 \mathrm{E}+03$ \\
30.6 & $0.2627 \mathrm{E}-06$ & $0.1262 \mathrm{E}+04$ & $0.2711 \mathrm{E}+03$ & $0.2631 \mathrm{E}-06$ & $0.1262 \mathrm{E}+04$ & $0.2711 \mathrm{E}+03$ \\
\hline
\end{tabular}

Table 19. Same as Table 18, but for case 2 and analytic solution given by Eq. (5)

\begin{tabular}{|r|c|c|c|c|c|c|}
\hline $\begin{array}{c}\mathrm{x} \\
(\mathrm{km})\end{array}$ & $\begin{array}{c}\text { Conc. (NS) } \\
(\mathrm{ppm})\end{array}$ & $\begin{array}{c}\sigma_{\mathrm{y}}(\mathrm{NS}) \\
(\mathrm{m})\end{array}$ & $\begin{array}{c}\sigma_{\mathrm{z}}(\mathrm{NS}) \\
(\mathrm{m})\end{array}$ & $\begin{array}{c}\text { Conc. }(\mathrm{AS}) \\
(\mathrm{ppm})\end{array}$ & $\begin{array}{c}\sigma_{\mathrm{y}}(\mathrm{AS}) \\
(\mathrm{m})\end{array}$ & $\begin{array}{c}\sigma_{\mathrm{z}}(\mathrm{AS}) \\
(\mathrm{m})\end{array}$ \\
\hline 1.8 & $0.5541 \mathrm{E}-02$ & $0.1954 \mathrm{E}+03$ & $0.5919 \mathrm{E}+02$ & $0.5534 \mathrm{E}-02$ & $0.1955 \mathrm{E}+03$ & $0.5919 \mathrm{E}+02$ \\
3.6 & $0.2971 \mathrm{E}-02$ & $0.3269 \mathrm{E}+03$ & $0.8843 \mathrm{E}+02$ & $0.2967 \mathrm{E}-02$ & $0.3271 \mathrm{E}+03$ & $0.8843 \mathrm{E}+02$ \\
5.4 & $0.1904 \mathrm{E}-02$ & $0.4450 \mathrm{E}+03$ & $0.1105 \mathrm{E}+03$ & $0.1901 \mathrm{E}-02$ & $0.4452 \mathrm{E}+03$ & $0.1105 \mathrm{E}+03$ \\
7.2 & $0.1363 \mathrm{E}-02$ & $0.5548 \mathrm{E}+03$ & $0.1288 \mathrm{E}+03$ & $0.1361 \mathrm{E}-02$ & $0.5551 \mathrm{E}+03$ & $0.1288 \mathrm{E}+03$ \\
9.0 & $0.1045 \mathrm{E}-02$ & $0.6589 \mathrm{E}+03$ & $0.1449 \mathrm{E}+03$ & $0.1043 \mathrm{E}-02$ & $0.6592 \mathrm{E}+03$ & $0.1449 \mathrm{E}+03$ \\
10.8 & $0.8468 \mathrm{E}-03$ & $0.7509 \mathrm{E}+03$ & $0.1593 \mathrm{E}+03$ & $0.8453 \mathrm{E}-03$ & $0.7512 \mathrm{E}+03$ & $0.1593 \mathrm{E}+03$ \\
12.6 & $0.7319 \mathrm{E}-03$ & $0.8108 \mathrm{E}+03$ & $0.1725 \mathrm{E}+03$ & $0.7307 \mathrm{E}-03$ & $0.8112 \mathrm{E}+03$ & $0.1725 \mathrm{E}+03$ \\
14.4 & $0.6445 \mathrm{E}-03$ & $0.8665 \mathrm{E}+03$ & $0.1848 \mathrm{E}+03$ & $0.6434 \mathrm{E}-03$ & $0.8670 \mathrm{E}+03$ & $0.1848 \mathrm{E}+03$ \\
16.2 & $0.5757 \mathrm{E}-03$ & $0.9189 \mathrm{E}+03$ & $0.1963 \mathrm{E}+03$ & $0.5747 \mathrm{E}-03$ & $0.9194 \mathrm{E}+03$ & $0.1963 \mathrm{E}+03$ \\
18.0 & $0.5202 \mathrm{E}-03$ & $0.9685 \mathrm{E}+03$ & $0.2071 \mathrm{E}+03$ & $0.5193 \mathrm{E}-03$ & $0.9690 \mathrm{E}+03$ & $0.2071 \mathrm{E}+03$ \\
19.8 & $0.4744 \mathrm{E}-03$ & $0.1016 \mathrm{E}+04$ & $0.2175 \mathrm{E}+03$ & $0.4736 \mathrm{E}-03$ & $0.1016 \mathrm{E}+04$ & $0.2175 \mathrm{E}+03$ \\
21.6 & $0.4361 \mathrm{E}-03$ & $0.1061 \mathrm{E}+04$ & $0.2273 \mathrm{E}+03$ & $0.4353 \mathrm{E}-03$ & $0.1061 \mathrm{E}+04$ & $0.2273 \mathrm{E}+03$ \\
23.4 & $0.4035 \mathrm{E}-03$ & $0.1104 \mathrm{E}+04$ & $0.2367 \mathrm{E}+03$ & $0.4027 \mathrm{E}-03$ & $0.1104 \mathrm{E}+04$ & $0.2367 \mathrm{E}+03$ \\
25.2 & $0.3754 \mathrm{E}-03$ & $0.1145 \mathrm{E}+04$ & $0.2458 \mathrm{E}+03$ & $0.3747 \mathrm{E}-03$ & $0.1146 \mathrm{E}+04$ & $0.2458 \mathrm{E}+03$ \\
27.0 & $0.3510 \mathrm{E}-03$ & $0.1185 \mathrm{E}+04$ & $0.2545 \mathrm{E}+03$ & $0.3503 \mathrm{E}-03$ & $0.1186 \mathrm{E}+04$ & $0.2545 \mathrm{E}+03$ \\
28.8 & $0.3296 \mathrm{E}-03$ & $0.1224 \mathrm{E}+04$ & $0.2630 \mathrm{E}+03$ & $0.3290 \mathrm{E}-03$ & $0.1225 \mathrm{E}+04$ & $0.2630 \mathrm{E}+03$ \\
30.6 & $0.3106 \mathrm{E}-03$ & $0.1262 \mathrm{E}+04$ & $0.2711 \mathrm{E}+03$ & $0.3100 \mathrm{E}-03$ & $0.1262 \mathrm{E}+04$ & $0.2711 \mathrm{E}+03$ \\
\hline
\end{tabular}


Table 20. Same as Table 18, but for case 3

\begin{tabular}{|c|c|c|c|c|c|c|}
\hline $\begin{array}{c}\mathrm{X} \\
(\mathrm{km})\end{array}$ & $\begin{array}{c}\text { Dose (NS) } \\
(\mathrm{rem})\end{array}$ & $\begin{array}{c}\sigma_{\mathrm{y}}(\mathrm{NS}) \\
(\mathrm{m})\end{array}$ & $\begin{array}{c}\sigma_{\mathrm{z}}(\mathrm{NS}) \\
(\mathrm{m})\end{array}$ & $\begin{array}{c}\text { Dose }(\mathrm{AS}) \\
(\mathrm{rem})\end{array}$ & $\begin{array}{c}\sigma_{\mathrm{y}}(\mathrm{AS}) \\
(\mathrm{m})\end{array}$ & $\begin{array}{c}\sigma_{\mathrm{z}}(\mathrm{AS}) \\
(\mathrm{m})\end{array}$ \\
\hline 1.8 & $0.2266 \mathrm{E}+02$ & $0.1954 \mathrm{E}+03$ & $0.5919 \mathrm{E}+02$ & $0.2271 \mathrm{E}+02$ & $0.1955 \mathrm{E}+03$ & $0.5919 \mathrm{E}+02$ \\
3.6 & $0.1215 \mathrm{E}+02$ & $0.3269 \mathrm{E}+03$ & $0.8843 \mathrm{E}+02$ & $0.1217 \mathrm{E}+02$ & $0.3271 \mathrm{E}+03$ & $0.8843 \mathrm{E}+02$ \\
5.4 & $0.7785 \mathrm{E}+01$ & $0.4450 \mathrm{E}+03$ & $0.1105 \mathrm{E}+03$ & $0.7798 \mathrm{E}+01$ & $0.4452 \mathrm{E}+03$ & $0.1105 \mathrm{E}+03$ \\
7.2 & $0.5575 \mathrm{E}+01$ & $0.5548 \mathrm{E}+03$ & $0.1288 \mathrm{E}+03$ & $0.5584 \mathrm{E}+01$ & $0.5551 \mathrm{E}+03$ & $0.1288 \mathrm{E}+03$ \\
9.0 & $0.4273 \mathrm{E}+01$ & $0.6589 \mathrm{E}+03$ & $0.1449 \mathrm{E}+03$ & $0.4280 \mathrm{E}+01$ & $0.6592 \mathrm{E}+03$ & $0.1449 \mathrm{E}+03$ \\
10.8 & $0.3462 \mathrm{E}+01$ & $0.7509 \mathrm{E}+03$ & $0.1593 \mathrm{E}+03$ & $0.3468 \mathrm{E}+01$ & $0.7512 \mathrm{E}+03$ & $0.1593 \mathrm{E}+03$ \\
12.6 & $0.2993 \mathrm{E}+01$ & $0.8108 \mathrm{E}+03$ & $0.1725 \mathrm{E}+03$ & $0.2998 \mathrm{E}+01$ & $0.8112 \mathrm{E}+03$ & $0.1725 \mathrm{E}+03$ \\
14.4 & $0.2635 \mathrm{E}+01$ & $0.8665 \mathrm{E}+03$ & $0.1848 \mathrm{E}+03$ & $0.2639 \mathrm{E}+01$ & $0.8670 \mathrm{E}+03$ & $0.1848 \mathrm{E}+03$ \\
16.2 & $0.2354 \mathrm{E}+01$ & $0.9189 \mathrm{E}+03$ & $0.1963 \mathrm{E}+03$ & $0.2358 \mathrm{E}+01$ & $0.9194 \mathrm{E}+03$ & $0.1963 \mathrm{E}+03$ \\
18.0 & $0.2127 \mathrm{E}+01$ & $0.9685 \mathrm{E}+03$ & $0.2071 \mathrm{E}+03$ & $0.2130 \mathrm{E}+01$ & $0.9690 \mathrm{E}+03$ & $0.2071 \mathrm{E}+03$ \\
19.8 & $0.1940 \mathrm{E}+01$ & $0.1016 \mathrm{E}+04$ & $0.2175 \mathrm{E}+03$ & $0.1943 \mathrm{E}+01$ & $0.1016 \mathrm{E}+04$ & $0.2175 \mathrm{E}+03$ \\
21.6 & $0.1783 \mathrm{E}+01$ & $0.1061 \mathrm{E}+04$ & $0.2273 \mathrm{E}+03$ & $0.1786 \mathrm{E}+01$ & $0.1061 \mathrm{E}+04$ & $0.2273 \mathrm{E}+03$ \\
23.4 & $0.1650 \mathrm{E}+01$ & $0.1104 \mathrm{E}+04$ & $0.2367 \mathrm{E}+03$ & $0.1652 \mathrm{E}+01$ & $0.1104 \mathrm{E}+04$ & $0.2367 \mathrm{E}+03$ \\
25.2 & $0.1535 \mathrm{E}+01$ & $0.1145 \mathrm{E}+04$ & $0.2458 \mathrm{E}+03$ & $0.1537 \mathrm{E}+01$ & $0.1146 \mathrm{E}+04$ & $0.2458 \mathrm{E}+03$ \\
27.0 & $0.1435 \mathrm{E}+01$ & $0.1185 \mathrm{E}+04$ & $0.2545 \mathrm{E}+03$ & $0.1437 \mathrm{E}+01$ & $0.1186 \mathrm{E}+04$ & $0.2545 \mathrm{E}+03$ \\
28.8 & $0.1348 \mathrm{E}+01$ & $0.1224 \mathrm{~F}+04$ & $0.2630 \mathrm{E}+03$ & $0.1350 \mathrm{E}+01$ & $0.1225 \mathrm{E}+04$ & $0.2630 \mathrm{E}+03$ \\
30.6 & $0.1270 \mathrm{E}+01$ & $0.1262 \mathrm{E}+04$ & $0.2711 \mathrm{E}+03$ & $0.1272 \mathrm{E}+01$ & $0.1262 \mathrm{E}+04$ & $0.2711 \mathrm{E}+03$ \\
\hline
\end{tabular}

Table 21. Same as Table 18, but for case 4

\begin{tabular}{|r|c|c|c|c|c|c|}
\hline $\begin{array}{c}\mathrm{x} \\
(\mathrm{km})\end{array}$ & $\begin{array}{c}\text { Dose (NS) } \\
(\mathrm{rem})\end{array}$ & $\begin{array}{c}\sigma_{\mathrm{y}}(\mathrm{NS}) \\
(\mathrm{m})\end{array}$ & $\begin{array}{c}\sigma_{\mathrm{z}}(\mathrm{NS}) \\
(\mathrm{m})\end{array}$ & $\begin{array}{c}\text { Dose (AS) } \\
(\mathrm{rem})\end{array}$ & $\begin{array}{c}\sigma_{\mathrm{y}}(\mathrm{AS}) \\
(\mathrm{m})\end{array}$ & $\begin{array}{c}\sigma_{\mathrm{z}}(\mathrm{AS}) \\
(\mathrm{m})\end{array}$ \\
\hline 1.8 & $0.1599 \mathrm{E}-04$ & $0.1954 \mathrm{E}+03$ & $0.5919 \mathrm{E}+02$ & $0.1602 \mathrm{E}-04$ & $0.1955 \mathrm{E}+03$ & $0.5919 \mathrm{E}+02$ \\
3.6 & $0.8403 \mathrm{E}-05$ & $0.3269 \mathrm{E}+03$ & $0.8843 \mathrm{E}+02$ & $0.8417 \mathrm{E}-05$ & $0.3271 \mathrm{E}+03$ & $0.8843 \mathrm{E}+02$ \\
5.4 & $0.5277 \mathrm{E}-05$ & $0.4450 \mathrm{E}+03$ & $0.1105 \mathrm{E}+03$ & $0.5285 \mathrm{E}-05$ & $0.4452 \mathrm{E}+03$ & $0.1105 \mathrm{E}+03$ \\
7.2 & $0.3703 \mathrm{E}-05$ & $0.5548 \mathrm{E}+03$ & $0.1288 \mathrm{E}+03$ & $0.3708 \mathrm{E}-05$ & $0.5551 \mathrm{E}+03$ & $0.1288 \mathrm{E}+03$ \\
9.0 & $0.2782 \mathrm{E}-05$ & $0.6589 \mathrm{E}+03$ & $0.1449 \mathrm{E}+03$ & $0.2785 \mathrm{E}-05$ & $0.6592 \mathrm{E}+03$ & $0.1449 \mathrm{E}+03$ \\
10.8 & $0.2209 \mathrm{E}-05$ & $0.7509 \mathrm{E}+03$ & $0.1593 \mathrm{E}+03$ & $0.2212 \mathrm{E}-05$ & $0.7512 \mathrm{E}+03$ & $0.1593 \mathrm{E}+03$ \\
12.6 & $0.1871 \mathrm{E}-05$ & $0.8108 \mathrm{E}+03$ & $0.1725 \mathrm{E}+03$ & $0.1874 \mathrm{E}-05$ & $0.8112 \mathrm{E}+03$ & $0.1725 \mathrm{E}+03$ \\
14.4 & $0.1615 \mathrm{E}-05$ & $0.8665 \mathrm{E}+03$ & $0.1848 \mathrm{E}+03$ & $0.1617 \mathrm{E}-05$ & $0.8670 \mathrm{E}+03$ & $0.1848 \mathrm{E}+03$ \\
16.2 & $0.1414 \mathrm{E}-05$ & $0.9189 \mathrm{E}+03$ & $0.1963 \mathrm{E}+03$ & $0.1416 \mathrm{E}-05$ & $0.9194 \mathrm{E}+03$ & $0.1963 \mathrm{E}+03$ \\
18.0 & $0.1252 \mathrm{E}-05$ & $0.9685 \mathrm{E}+03$ & $0.2071 \mathrm{E}+03$ & $0.1253 \mathrm{E}-05$ & $-9690 \mathrm{E}+03$ & $0.2071 \mathrm{E}+03$ \\
19.8 & $0.1119 \mathrm{E}-05$ & $0.1016 \mathrm{E}+04$ & $0.2175 \mathrm{E}+03$ & $0.1120 \mathrm{E}-05$ & $0.1016 \mathrm{E}+04$ & $0.2175 \mathrm{E}+03$ \\
21.6 & $0.1008 \mathrm{E}-05$ & $0.1061 \mathrm{E}+04$ & $0.2273 \mathrm{E}+03$ & $0.1009 \mathrm{E}-05$ & $0.1061 \mathrm{E}+04$ & $0.2273 \mathrm{E}+03$ \\
23.4 & $0.9138 \mathrm{E}-06$ & $0.1104 \mathrm{E}+04$ & $0.2367 \mathrm{E}+03$ & $0.9150 \mathrm{E}-06$ & $0.1104 \mathrm{E}+04$ & $0.2367 \mathrm{E}+03$ \\
25.2 & $0.8333 \mathrm{E}-06$ & $0.1145 \mathrm{E}+04$ & $0.2458 \mathrm{E}+03$ & $0.8344 \mathrm{E}-06$ & $0.1146 \mathrm{E}+04$ & $0.2458 \mathrm{E}+03$ \\
27.0 & $0.7635 \mathrm{E}-06$ & $0.1185 \mathrm{E}+04$ & $0.2545 \mathrm{E}+03$ & $0.7645 \mathrm{E}-06$ & $0.1186 \mathrm{E}+04$ & $0.2545 \mathrm{E}+03$ \\
28.8 & $0.7025 \mathrm{E}-06$ & $0.1224 \mathrm{E}+04$ & $0.2630 \mathrm{E}+03$ & $0.7035 \mathrm{E}-06$ & $0.1225 \mathrm{E}+04$ & $0.2630 \mathrm{E}+03$ \\
30.6 & $0.6489 \mathrm{E}-06$ & $0.1262 \mathrm{E}+04$ & $0.2711 \mathrm{E}+03$ & $0.6497 \mathrm{E}-06$ & $0.1262 \mathrm{E}+04$ & $0.2711 \mathrm{E}+03$ \\
\hline
\end{tabular}


Table 22. Same as Table 18, but for case 5

\begin{tabular}{|c|c|c|c|c|c|c|}
\hline $\begin{array}{c}\mathrm{x} \\
(\mathrm{km})\end{array}$ & $\begin{array}{c}\text { Dose (NS) } \\
(\mathrm{rem})\end{array}$ & $\begin{array}{c}\sigma_{\mathrm{y}}(\mathrm{NS}) \\
(\mathrm{m})\end{array}$ & $\begin{array}{c}\sigma_{\mathrm{z}}(\mathrm{NS}) \\
(\mathrm{m})\end{array}$ & $\begin{array}{c}\text { Dose (AS) } \\
(\mathrm{rem})\end{array}$ & $\begin{array}{c}\sigma_{\mathrm{y}}(\mathrm{AS}) \\
(\mathrm{m})\end{array}$ & $\begin{array}{c}\sigma_{\mathrm{z}}(\mathrm{AS}) \\
(\mathrm{m})\end{array}$ \\
\hline 1.8 & $0.4687 \mathrm{E}-05$ & $0.1954 \mathrm{E}+03$ & $0.5919 \mathrm{E}+02$ & $0.4697 \mathrm{E}-05$ & $0.1955 \mathrm{E}+03$ & $0.5919 \mathrm{E}+02$ \\
3.6 & $0.2514 \mathrm{E}-05$ & $0.3269 \mathrm{E}+03$ & $0.8843 \mathrm{E}+02$ & $0.2518 \mathrm{E}-05$ & $0.3271 \mathrm{E}+03$ & $0.8843 \mathrm{E}+02$ \\
5.4 & $0.1611 \mathrm{E}-05$ & $0.4450 \mathrm{E}+03$ & $0.1105 \mathrm{E}+03$ & $0.1613 \mathrm{E}-05$ & $0.4452 \mathrm{E}+03$ & $0.1105 \mathrm{E}+03$ \\
7.2 & $0.1153 \mathrm{E}-05$ & $0.5548 \mathrm{E}+03$ & $0.1288 \mathrm{E}+03$ & $0.1155 \mathrm{E}-05$ & $0.5551 \mathrm{E}+03$ & $0.1288 \mathrm{E}+03$ \\
9.0 & $0.8840 \mathrm{E}-06$ & $0.6589 \mathrm{E}+03$ & $0.1449 \mathrm{E}+03$ & $0.8853 \mathrm{E}-06$ & $0.6592 \mathrm{E}+03$ & $0.1449 \mathrm{E}+03$ \\
10.8 & $0.7164 \mathrm{E}-06$ & $0.7509 \mathrm{E}+03$ & $0.1593 \mathrm{E}+03$ & $0.7174 \mathrm{E}-06$ & $0.7512 \mathrm{E}+03$ & $0.1593 \mathrm{E}+03$ \\
12.6 & $0.6192 \mathrm{E}-06$ & $0.8108 \mathrm{E}+03$ & $0.1725 \mathrm{E}+03$ & $0.6201 \mathrm{E}-06$ & $0.8112 \mathrm{E}+03$ & $0.1725 \mathrm{E}+03$ \\
14.4 & $0.5453 \mathrm{E}-06$ & $0.8665 \mathrm{E}+03$ & $0.1848 \mathrm{E}+03$ & $0.5460 \mathrm{E}-06$ & $0.8670 \mathrm{E}+03$ & $0.1848 \mathrm{E}+03$ \\
16.2 & $0.4871 \mathrm{E}-06$ & $0.9189 \mathrm{E}+03$ & $0.1963 \mathrm{E}+03$ & $0.4877 \mathrm{E}-06$ & $0.9194 \mathrm{E}+03$ & $0.1963 \mathrm{E}+03$ \\
18.0 & $0.4401 \mathrm{E}-06$ & $0.9685 \mathrm{E}+03$ & $0.20711 \mathrm{E}+03$ & $0.4407 \mathrm{E}-06$ & $0.9690 \mathrm{E}+03$ & $0.2071 \mathrm{E}+03$ \\
19.8 & $0.4014 \mathrm{E}-06$ & $0.1016 \mathrm{E}+04$ & $0.2175 \mathrm{E}+03$ & $0.4019 \mathrm{E}-06$ & $0.1016 \mathrm{E}+04$ & $0.2175 \mathrm{E}+03$ \\
21.6 & $0.3689 \mathrm{E}-06$ & $0.1061 \mathrm{E}+04$ & $0.2273 \mathrm{E}+03$ & $0.3694 \mathrm{E}-06$ & $0.1061 \mathrm{E}+04$ & $0.2273 \mathrm{E}+03$ \\
23.4 & $0.3413 \mathrm{E}-06$ & $0.1104 \mathrm{E}+04$ & $0.2367 \mathrm{E}+03$ & $0.3418 \mathrm{E}-06$ & $0.1104 \mathrm{E}+04$ & $0.2367 \mathrm{E}+03$ \\
25.2 & $0.3176 \mathrm{E}-06$ & $0.1145 \mathrm{E}+04$ & $0.2458 \mathrm{E}+03$ & $0.3180 \mathrm{E}-06$ & $0.1146 \mathrm{E}+04$ & $0.2458 \mathrm{E}+03$ \\
27.0 & $0.2969 \mathrm{E}-06$ & $0.1185 \mathrm{E}+04$ & $0.2545 \mathrm{E}+03$ & $0.2973 \mathrm{E}-06$ & $0.1186 \mathrm{E}+04$ & $0.2545 \mathrm{E}+03$ \\
28.8 & $0.2788 \mathrm{E}-06$ & $0.1224 \mathrm{E}+04$ & $0.2630 \mathrm{E}+03$ & $0.2792 \mathrm{E}-06$ & $0.1225 \mathrm{E}+04$ & $0.2630 \mathrm{E}+03$ \\
30.6 & $0.2628 \mathrm{E}-06$ & $0.1262 \mathrm{E}+04$ & $0.2711 \mathrm{E}+03$ & $0.2631 \mathrm{E}-06$ & $0.1262 \mathrm{E}+04$ & $0.2711 \mathrm{E}+03$ \\
\hline
\end{tabular}

Table 23. Same as Table 18, but for case 6

\begin{tabular}{|c|c|c|c|c|c|c|}
\hline $\begin{array}{c}\mathrm{x} \\
(\mathrm{km})\end{array}$ & $\begin{array}{c}\text { Dose }(\mathrm{NS}) \\
(\mathrm{rem})\end{array}$ & $\begin{array}{c}\sigma_{\mathrm{y}}(\mathrm{NS}) \\
(\mathrm{m})\end{array}$ & $\begin{array}{c}\sigma_{\mathrm{z}}(\mathrm{NS}) \\
(\mathrm{m})\end{array}$ & $\begin{array}{c}\text { Dose }(\mathrm{AS}) \\
(\mathrm{rem})\end{array}$ & $\begin{array}{c}\sigma_{\mathrm{y}}(\mathrm{AS}) \\
(\mathrm{m})\end{array}$ & $\begin{array}{c}\sigma_{\mathrm{z}}(\mathrm{AS}) \\
(\mathrm{m})\end{array}$ \\
\hline 1.8 & $0.5389 \mathrm{E}-06$ & $0.4647 \mathrm{E}+03$ & $0.3630 \mathrm{E}+03$ & $0.5396 \mathrm{E}-06$ & $0.4649 \mathrm{E}+03$ & $0.3630 \mathrm{E}+03$ \\
3.6 & $0.1628 \mathrm{E}-06$ & $0.7804 \mathrm{E}+03$ & $0.7230 \mathrm{E}+03$ & $0.1630 \mathrm{E}-06$ & $0.7808 \mathrm{E}+03$ & $0.7230 \mathrm{E}+03$ \\
5.4 & $0.1080 \mathrm{E}-06$ & $0.1064 \mathrm{E}+04$ & $0.8000 \mathrm{E}+03$ & $0.1082 \mathrm{E}-06$ & $0.1064 \mathrm{E}+04$ & $0.8000 \mathrm{E}+03$ \\
7.2 & $0.8658 \mathrm{E}-07$ & $0.1327 \mathrm{E}+04$ & $0.8000 \mathrm{E}+03$ & $0.8670 \mathrm{E}-07$ & $0.1328 \mathrm{E}+04$ & $0.8000 \mathrm{E}+03$ \\
9.0 & $0.7287 \mathrm{E}-07$ & $0.1577 \mathrm{E}+04$ & $0.8000 \mathrm{E}+03$ & $0.7296 \mathrm{E}-07$ & $0.1578 \mathrm{E}+04$ & $0.8000 \mathrm{E}+03$ \\
10.8 & $0.6392 \mathrm{E}-07$ & $0.1798 \mathrm{E}+04$ & $0.8000 \mathrm{E}+03$ & $0.6400 \mathrm{E}-07$ & $0.1799 \mathrm{E}+04$ & $0.8000 \mathrm{E}+03$ \\
12.6 & $0.5919 \mathrm{E}-07$ & $0.1942 \mathrm{E}+04$ & $0.8000 \mathrm{E}+03$ & $0.5926 \mathrm{E}-07$ & $0.1943 \mathrm{E}+04$ & $0.8000 \mathrm{E}+03$ \\
14.4 & $0.5537 \mathrm{E}-07$ & $0.2075 \mathrm{E}+04$ & $0.8000 \mathrm{E}+03$ & $0.5544 \mathrm{E}-07$ & $0.2077 \mathrm{E}+04$ & $0.8000 \mathrm{E}+03$ \\
16.2 & $0.5221 \mathrm{E}-07$ & $0.2201 \mathrm{E}+04$ & $0.8000 \mathrm{E}+03$ & $0.5227 \mathrm{E}-07$ & $0.2202 \mathrm{E}+04$ & $0.8000 \mathrm{E}+03$ \\
18.0 & $0.4953 \mathrm{E}-07$ & $0.2320 \mathrm{E}+04$ & $0.8000 \mathrm{E}+03$ & $0.4960 \mathrm{E}-07$ & $0.2321 \mathrm{E}+04$ & $0.8000 \mathrm{E}+03$ \\
19.8 & $0.4723 \mathrm{E}-07$ & $0.2433 \mathrm{E}+04$ & $0.8000 \mathrm{E}+03$ & $0.4729 \mathrm{E}-07$ & $0.2434 \mathrm{E}+04$ & $0.8000 \mathrm{E}+03$ \\
21.6 & $0.4522 \mathrm{E}-07$ & $0.2541 \mathrm{E}+04$ & $0.8000 \mathrm{E}+03$ & $0.4528 \mathrm{E}-07$ & $0.2542 \mathrm{E}+04$ & $0.8000 \mathrm{E}+03$ \\
23.4 & $0.4345 \mathrm{E}-07$ & $0.2645 \mathrm{E}+04$ & $0.8000 \mathrm{E}+03$ & $0.4351 \mathrm{E}-07$ & $0.2646 \mathrm{E}+04$ & $0.8000 \mathrm{E}+03$ \\
25.2 & $0.4187 \mathrm{E}-07$ & $0.2745 \mathrm{E}+04$ & $0.8000 \mathrm{E}+03$ & $0.4192 \mathrm{E}-07$ & $0.2746 \mathrm{E}+04$ & $0.8000 \mathrm{E}+03$ \\
27.0 & $0.4045 \mathrm{E}-07$ & $0.2841 \mathrm{E}+04$ & $0.8000 \mathrm{E}+03$ & $0.4050 \mathrm{E}-07$ & $0.2842 \mathrm{E}+04$ & $0.8000 \mathrm{E}+03$ \\
28.8 & $0.3917 \mathrm{E}-07$ & $0.2934 \mathrm{E}+04$ & $0.8000 \mathrm{E}+03$ & $0.3922 \mathrm{E}-07$ & $0.2935 \mathrm{E}+04$ & $0.8000 \mathrm{E}+03$ \\
30.6 & $0.3800 \mathrm{E}-07$ & $0.3024 \mathrm{E}+04$ & $0.8000 \mathrm{E}+03$ & $0.3805 \mathrm{E}-07$ & $0.3026 \mathrm{E}+04$ & $0.8000 \mathrm{E}+03$ \\
\hline
\end{tabular}


Table 24. Same as Table 18 , but for case 7

\begin{tabular}{|c|c|c|c|c|c|c|}
\hline $\begin{array}{c}\mathrm{x} \\
(\mathrm{km})\end{array}$ & $\begin{array}{c}\text { Dose }(\mathrm{NS}) \\
(\mathrm{rem})\end{array}$ & $\begin{array}{c}\sigma_{\mathrm{y}}(\mathrm{NS}) \\
(\mathrm{m})\end{array}$ & $\begin{array}{c}\sigma_{\mathrm{z}}(\mathrm{NS}) \\
(\mathrm{m})\end{array}$ & $\begin{array}{c}\text { Dose }(\mathrm{AS}) \\
(\mathrm{rem})\end{array}$ & $\begin{array}{c}\sigma_{\mathrm{y}}(\mathrm{AS}) \\
(\mathrm{m})\end{array}$ & $\begin{array}{c}\sigma_{\mathrm{z}}(\mathrm{AS}) \\
(\mathrm{m})\end{array}$ \\
\hline 1.8 & $0.5388 \mathrm{E}-06$ & $0.4647 \mathrm{E}+03$ & $0.3630 \mathrm{E}+03$ & $0.5396 \mathrm{E}-06$ & $0.4649 \mathrm{E}+03$ & $0.3630 \mathrm{E}+03$ \\
3.6 & $0.2919 \mathrm{E}-06$ & $0.7804 \mathrm{E}+03$ & $0.4000 \mathrm{E}+03$ & $0.2923 \mathrm{E}-06$ & $0.7808 \mathrm{E}+03$ & $0.4000 \mathrm{E}+03$ \\
5.4 & $0.2142 \mathrm{E}-06$ & $0.1064 \mathrm{E}+04$ & $0.4000 \mathrm{E}+03$ & $0.2145 \mathrm{E}-06$ & $0.1064 \mathrm{E}+04$ & $0.4000 \mathrm{E}+03$ \\
7.2 & $0.1716 \mathrm{E}-06$ & $0.1327 \mathrm{E}+04$ & $0.4000 \mathrm{E}+03$ & $0.1719 \mathrm{E}-06$ & $0.1328 \mathrm{E}+04$ & $0.4000 \mathrm{E}+03$ \\
9.0 & $0.1444 \mathrm{E}-06$ & $0.1577 \mathrm{E}+04$ & $0.4000 \mathrm{E}+03$ & $0.1447 \mathrm{E}-06$ & $0.1578 \mathrm{E}+04$ & $0.4000 \mathrm{E}+03$ \\
10.8 & $0.1267 \mathrm{E}-06$ & $0.1798 \mathrm{E}+04$ & $0.4000 \mathrm{E}+03$ & $0.1269 \mathrm{E}-06$ & $0.1799 \mathrm{E}+04$ & $0.4000 \mathrm{E}+03$ \\
12.6 & $0.1173 \mathrm{E}-06$ & $0.1942 \mathrm{E}+04$ & $0.4000 \mathrm{E}+03$ & $0.1175 \mathrm{E}-06$ & $0.1943 \mathrm{E}+04$ & $0.4000 \mathrm{E}+03$ \\
14.4 & $0.1098 \mathrm{E}-06$ & $0.2075 \mathrm{E}+04$ & $0.4000 \mathrm{E}+03$ & $0.1099 \mathrm{E}-06$ & $0.2077 \mathrm{E}+04$ & $0.4000 \mathrm{E}+03$ \\
16.2 & $0.1035 \mathrm{E}-06$ & $0.2201 \mathrm{E}+04$ & $0.4000 \mathrm{E}+03$ & $0.1036 \mathrm{E}-06$ & $0.2202 \mathrm{E}+04$ & $0.4000 \mathrm{E}+03$ \\
18.0 & $0.9819 \mathrm{E}-07$ & $0.2320 \mathrm{E}+04$ & $0.4000 \mathrm{E}+03$ & $0.9833 \mathrm{E}-07$ & $0.2321 \mathrm{E}+04$ & $0.4000 \mathrm{E}+03$ \\
19.8 & $0.9362 \mathrm{E}-07$ & $0.2433 \mathrm{E}+04$ & $0.4000 \mathrm{E}+03$ & $0.9376 \mathrm{E}-07$ & $0.2434 \mathrm{E}+04$ & $0.4000 \mathrm{E}+03$ \\
21.6 & $0.8964 \mathrm{E}-07$ & $0.2541 \mathrm{E}+04$ & $0.4000 \mathrm{E}+03$ & $0.8977 \mathrm{E}-07$ & $0.2542 \mathrm{E}+04$ & $0.4000 \mathrm{E}+03$ \\
23.4 & $0.8613 \mathrm{E}-07$ & $0.2645 \mathrm{E}+04$ & $0.4000 \mathrm{E}+03$ & $0.8626 \mathrm{E}-07$ & $0.2646 \mathrm{E}+04$ & $0.4000 \mathrm{E}+03$ \\
25.2 & $0.8300 \mathrm{E}-07$ & $0.2745 \mathrm{E}+04$ & $0.4000 \mathrm{E}+03$ & $0.8312 \mathrm{E}-07$ & $0.2746 \mathrm{E}+04$ & $0.4000 \mathrm{E}+03$ \\
27.0 & $0.8019 \mathrm{E}-07$ & $0.2841 \mathrm{E}+04$ & $0.4000 \mathrm{E}+03$ & $0.8031 \mathrm{E}-07$ & $0.2842 \mathrm{E}+04$ & $0.4000 \mathrm{E}+03$ \\
28.8 & $0.7764 \mathrm{E}-07$ & $0.2934 \mathrm{E}+04$ & $0.4000 \mathrm{E}+03$ & $0.7776 \mathrm{E}-07$ & $0.2935 \mathrm{E}+04$ & $0.4000 \mathrm{E}+03$ \\
30.6 & $0.7533 \mathrm{E}-07$ & $0.3024 \mathrm{E}+04$ & $0.4000 \mathrm{E}+03$ & $0.7544 \mathrm{E}-07$ & $0.3026 \mathrm{E}+04$ & $0.4000 \mathrm{E}+03$ \\
\hline
\end{tabular}

Table 25. Same as Table 18, but for case 8

\begin{tabular}{|r|c|c|c|c|c|c|}
\hline $\begin{array}{c}\mathrm{x} \\
(\mathrm{km})\end{array}$ & $\begin{array}{c}\text { Dose }(\mathrm{NS}) \\
(\mathrm{rem})\end{array}$ & $\begin{array}{c}\sigma_{\mathrm{y}}(\mathrm{NS}) \\
(\mathrm{m})\end{array}$ & $\begin{array}{c}\sigma_{\mathrm{z}}(\mathrm{NS}) \\
(\mathrm{m})\end{array}$ & $\begin{array}{c}\text { Dose }(\mathrm{AS}) \\
(\mathrm{rem})\end{array}$ & $\begin{array}{c}\sigma_{\mathrm{y}}(\mathrm{AS}) \\
(\mathrm{m})\end{array}$ & $\begin{array}{c}\sigma_{\mathrm{z}}(\mathrm{AS}) \\
(\mathrm{m})\end{array}$ \\
\hline 1.8 & $0.1159 \mathrm{E}-05$ & $0.3493 \mathrm{E}+03$ & $0.2190 \mathrm{E}+03$ & $0.1161 \mathrm{E}-05$ & $0.3495 \mathrm{E}+03$ & $0.2190 \mathrm{E}+03$ \\
3.6 & $0.3888 \mathrm{E}-06$ & $0.5861 \mathrm{E}+03$ & $0.4000 \mathrm{E}+03$ & $0.3893 \mathrm{E}-06$ & $0.5864 \mathrm{E}+03$ & $0.4000 \mathrm{E}+03$ \\
5.4 & $0.2853 \mathrm{E}-06$ & $0.7985 \mathrm{E}+03$ & $0.4000 \mathrm{E}+03$ & $0.2857 \mathrm{E}-06$ & $0.7989 \mathrm{E}+03$ & $0.4000 \mathrm{E}+03$ \\
7.2 & $0.2287 \mathrm{E}-06$ & $0.9962 \mathrm{E}+03$ & $0.4000 \mathrm{E}+03$ & $0.2290 \mathrm{E}-06$ & $0.9967 \mathrm{E}+03$ & $0.4000 \mathrm{E}+03$ \\
9.0 & $0.1925 \mathrm{E}-06$ & $0.1184 \mathrm{E}+04$ & $0.4000 \mathrm{E}+03$ & $0.1928 \mathrm{E}-06$ & $0.1184 \mathrm{E}+04$ & $0.4000 \mathrm{E}+03$ \\
10.8 & $0.1689 \mathrm{E}-06$ & $0.1349 \mathrm{E}+04$ & $0.4000 \mathrm{E}+03$ & $0.1691 \mathrm{E}-06$ & $0.1350 \mathrm{E}+04$ & $0.4000 \mathrm{E}+03$ \\
12.6 & $0.1564 \mathrm{E}-06$ & $0.1457 \mathrm{E}+04$ & $0.4000 \mathrm{E}+03$ & $0.1566 \mathrm{E}-06$ & $0.1458 \mathrm{E}+04$ & $0.4000 \mathrm{E}+03$ \\
14.4 & $0.1463 \mathrm{E}-06$ & $0.1557 \mathrm{E}+04$ & $0.4000 \mathrm{E}+03$ & $0.1465 \mathrm{E}-06$ & $0.1558 \mathrm{E}+04$ & $0.4000 \mathrm{E}+03$ \\
16.2 & $0.1379 \mathrm{E}-06$ & $0.1652 \mathrm{E}+04$ & $0.4000 \mathrm{E}+03$ & $0.1381 \mathrm{E}-06$ & $0.1652 \mathrm{E}+04$ & $0.4000 \mathrm{E}+03$ \\
18.0 & $0.1309 \mathrm{E}-06$ & $0.1741 \mathrm{E}+04$ & $0.4000 \mathrm{E}+03$ & $0.1311 \mathrm{E}-06$ & $0.1742 \mathrm{E}+04$ & $0.4000 \mathrm{E}+03$ \\
19.8 & $0.1248 \mathrm{E}-06$ & $0.1826 \mathrm{E}+04$ & $0.4000 \mathrm{E}+03$ & $0.1250 \mathrm{E}-06$ & $0.1827 \mathrm{E}+04$ & $0.4000 \mathrm{E}+03$ \\
21.6 & $0.1195 \mathrm{E}-06$ & $0.1907 \mathrm{E}+04$ & $0.4000 \mathrm{E}+03$ & 0.1197 .26 & $0.1908 \mathrm{E}+04$ & $0.4000 \mathrm{E}+03$ \\
23.4 & $0.1148 \mathrm{E}-06$ & $0.1984 \mathrm{E}+04$ & $0.4000 \mathrm{E}+03$ & $0.1150 \mathrm{E}-1$ & $0.1985 \mathrm{E}+04$ & $0.4000 \mathrm{E}+03$ \\
25.2 & $0.1106 \mathrm{E}-06$ & $0.2059 \mathrm{E}+04$ & $0.4000 \mathrm{E}+03$ & $0.1108 \mathrm{E}-06$ & $0.2060 \mathrm{E}+04$ & $0.4000 \mathrm{E}+03$ \\
27.0 & $0.1069 \mathrm{E}-06$ & $0.2131 \mathrm{E}+04$ & $0.4000 \mathrm{E}+03$ & $0.1070 \mathrm{E}-06$ & $0.2132 \mathrm{E}+04$ & $0.4000 \mathrm{E}+03$ \\
28.8 & $0.1035 \mathrm{E}-06$ & $0.2201 \mathrm{E}+04$ & $0.4000 \mathrm{E}+03$ & $0.1036 \mathrm{E}-06$ & $0.2202 \mathrm{E}+04$ & $0.4000 \mathrm{E}+03$ \\
30.6 & $0.1004 \mathrm{E}-06$ & $0.2269 \mathrm{E}+04$ & $0.4000 \mathrm{E}+03$ & $0.1006 \mathrm{E}-06$ & $0.2270 \mathrm{E}+04$ & $0.4000 \mathrm{E}+03$ \\
\hline
\end{tabular}


Table 26. Same as Table 18, but for case 9

\begin{tabular}{|r|c|c|c|c|c|c|}
\hline $\begin{array}{c}\mathrm{x} \\
(\mathrm{km})\end{array}$ & $\begin{array}{c}\text { Dose (NS) } \\
(\mathrm{rem})\end{array}$ & $\begin{array}{c}\sigma_{\mathrm{y}}(\mathrm{NS}) \\
(\mathrm{m})\end{array}$ & $\begin{array}{c}\sigma_{\mathrm{z}}(\mathrm{NS}) \\
(\mathrm{m})\end{array}$ & $\begin{array}{c}\text { Dose }(\mathrm{AS}) \\
(\mathrm{rem})\end{array}$ & $\begin{array}{c}\sigma_{\mathrm{y}}(\mathrm{AS}) \\
(\mathrm{m})\end{array}$ & $\begin{array}{c}\sigma_{\mathrm{z}}(\mathrm{AS}) \\
(\mathrm{m})\end{array}$ \\
\hline 1.8 & $0.2382 \mathrm{E}-05$ & $0.2723 \mathrm{E}+03$ & $0.1265 \mathrm{E}+03$ & $0.2386 \mathrm{E}-05$ & $0.2725 \mathrm{E}+03$ & $0.1265 \mathrm{E}+03$ \\
3.6 & $0.8737 \mathrm{E}-06$ & $0.4565 \mathrm{E}+03$ & $0.2226 \mathrm{E}+03$ & $0.8749 \mathrm{E}-06$ & $0.4567 \mathrm{E}+03$ & $0.2226 \mathrm{E}+03$ \\
5.4 & $0.4802 \mathrm{E}-06$ & $0.6217 \mathrm{E}+03$ & $0.3026 \mathrm{E}+03$ & $0.4809 \mathrm{E}-06$ & $0.6220 \mathrm{E}+03$ & $0.3026 \mathrm{E}+03$ \\
7.2 & $0.3155 \mathrm{E}-06$ & $0.1755 \mathrm{E}+03$ & $0.3718 \mathrm{E}+03$ & $0.3159 \mathrm{E}-06$ & $0.7759 \mathrm{E}+03$ & $0.3718 \mathrm{E}+03$ \\
9.0 & $0.2473 \mathrm{E}-06$ & $0.9212 \mathrm{E}+03$ & $0.4000 \mathrm{E}+03$ & $0.2476 \mathrm{E}-06$ & $0.9217 \mathrm{E}+03$ & $0.4000 \mathrm{E}+03$ \\
10.8 & $0.2170 \mathrm{E}-06$ & $0.1050 \mathrm{E}+04$ & $0.4000 \mathrm{E}+03$ & $0.2173 \mathrm{E}-06$ & $0.1051 \mathrm{E}+04$ & $0.4000 \mathrm{E}+03$ \\
12.6 & $0.2009 \mathrm{E}-06$ & $0.1134 \mathrm{E}+04$ & $0.4000 \mathrm{E}+03$ & $0.2012 \mathrm{E}-06$ & $0.1134 \mathrm{E}+04$ & $0.4000 \mathrm{E}+03$ \\
14.4 & $0.1880 \mathrm{E}-06$ & $0.1212 \mathrm{E}+04$ & $0.4000 \mathrm{E}+03$ & $0.1882 \mathrm{E}-06$ & $0.1213 \mathrm{E}+04$ & $0.4000 \mathrm{E}+03$ \\
16.2 & $0.1773 \mathrm{E}-06$ & $0.1285 \mathrm{E}+04$ & $0.4000 \mathrm{E}+03$ & $0.1775 \mathrm{E}-06$ & $0.1286 \mathrm{E}+04$ & $0.4000 \mathrm{E}+03$ \\
18.0 & $0.1682 \mathrm{E}-06$ & $0.1355 \mathrm{E}+04$ & $0.4000 \mathrm{E}+03$ & $0.1684 \mathrm{E}-06$ & $0.1355 \mathrm{E}+04$ & $0.4000 \mathrm{E}+03$ \\
19.8 & $0.1604 \mathrm{E}-06$ & $0.1421 \mathrm{E}+04$ & $0.4000 \mathrm{E}+03$ & $0.1606 \mathrm{E}-06$ & $0.1421 \mathrm{E}+04$ & $0.4000 \mathrm{E}+03$ \\
21.6 & $0.1536 \mathrm{E}-06$ & $0.1484 \mathrm{E}+04$ & $0.4000 \mathrm{E}+03$ & $0.1538 \mathrm{E}-06$ & $0.1484 \mathrm{E}+04$ & $0.4000 \mathrm{E}+03$ \\
23.4 & $0.1476 \mathrm{E}-06$ & $0.1544 \mathrm{E}+04$ & $0.4000 \mathrm{E}+03$ & $0.1477 \mathrm{E}-06$ & $0.1545 \mathrm{E}+04$ & $0.4000 \mathrm{E}+03$ \\
25.2 & $0.1422 \mathrm{E}-06$ & $0.1602 \mathrm{E}+04$ & $0.4000 \mathrm{E}+03$ & $0.1424 \mathrm{E}-06$ & $0.1603 \mathrm{E}+04$ & $0.4000 \mathrm{E}+03$ \\
27.0 & $0.1374 \mathrm{E}-06$ & $0.1658 \mathrm{E}+04$ & $0.4000 \mathrm{E}+03$ & $0.1376 \mathrm{E}-06$ & $0.1659 \mathrm{E}+04$ & $0.4000 \mathrm{E}+03$ \\
28.8 & $0.1330 \mathrm{E}-06$ & $0.1713 \mathrm{E}+04$ & $0.4000 \mathrm{E}+03$ & $0.1332 \mathrm{E}-06$ & $0.1714 \mathrm{E}+04$ & $0.4000 \mathrm{E}+03$ \\
30.6 & $0.1291 \mathrm{E}-06$ & $0.1765 \mathrm{E}+04$ & $0.4000 \mathrm{E}+03$ & $0.1292 \mathrm{E}-06$ & $0.1766 \mathrm{E}+04$ & $0.4000 \mathrm{E}+03$ \\
\hline
\end{tabular}

Table 27. Same as Table 18 , but for case 10

\begin{tabular}{|r|c|c|c|c|c|c|}
\hline $\begin{array}{c}\mathrm{x} \\
(\mathrm{km})\end{array}$ & $\begin{array}{c}\text { Dose (NS) } \\
(\mathrm{rem})\end{array}$ & $\begin{array}{c}\sigma_{\mathrm{y}}(\mathrm{NS}) \\
(\mathrm{m})\end{array}$ & $\begin{array}{c}\sigma_{\mathrm{z}}(\mathrm{NS}) \\
(\mathrm{m})\end{array}$ & $\begin{array}{c}\text { Dose }(\mathrm{AS}) \\
(\mathrm{rem})\end{array}$ & $\begin{array}{c}\sigma_{\mathrm{y}}(\mathrm{AS}) \\
(\mathrm{m})\end{array}$ & $\begin{array}{c}\sigma_{\mathrm{z}}(\mathrm{AS}) \\
(\mathrm{m})\end{array}$ \\
\hline 1.8 & $0.5672 \mathrm{E}-05$ & $0.1185 \mathrm{E}+03$ & $0.3811 \mathrm{E}+02$ & $0.5690 \mathrm{E}-05$ & $0.1185 \mathrm{E}+03$ & $0.3811 \mathrm{E}+02$ \\
3.6 & $0.4590 \mathrm{E}-05$ & $0.1974 \mathrm{E}+03$ & $0.5497 \mathrm{E}+02$ & $0.4601 \mathrm{E}-05$ & $0.1975 \mathrm{E}+03$ & $0.5497 \mathrm{E}+02$ \\
5.4 & $0.3405 \mathrm{E}-05$ & $0.2682 \mathrm{E}+03$ & $0.6488 \mathrm{E}+02$ & $0.3412 \mathrm{E}-05$ & $0.2683 \mathrm{E}+03$ & $0.6488 \mathrm{E}+02$ \\
7.2 & $0.2683 \mathrm{E}-05$ & $0.3341 \mathrm{E}+03$ & $0.7140 \mathrm{E}+02$ & $0.2688 \mathrm{E}-05$ & $0.3343 \mathrm{E}+03$ & $0.7140 \mathrm{E}+02$ \\
9.0 & $0.2216 \mathrm{E}-05$ & $0.3966 \mathrm{E}+03$ & $0.7602 \mathrm{E}+02$ & $0.2220 \mathrm{E}-05$ & $0.3968 \mathrm{E}+03$ & $0.7602 \mathrm{E}+02$ \\
10.8 & $0.1913 \mathrm{E}-05$ & $0.4517 \mathrm{E}+03$ & $0.7946 \mathrm{E}+02$ & $0.1916 \mathrm{E}-05$ & $0.4520 \mathrm{E}+03$ & $0.7946 \mathrm{E}+02$ \\
12.6 & $0.1747 \mathrm{E}-05$ & $0.4877 \mathrm{E}+03$ & $0.8213 \mathrm{E}+02$ & $0.1750 \mathrm{E}-05$ & $0.4879 \mathrm{E}+03$ & $0.8213 \mathrm{E}+02$ \\
14.4 & $0.1615 \mathrm{E}-05$ & $0.5211 \mathrm{E}+03$ & $0.8425 \mathrm{E}+02$ & $0.1618 \mathrm{E}-05$ & $0.5214 \mathrm{E}+03$ & $0.8425 \mathrm{E}+02$ \\
16.2 & $0.1509 \mathrm{E}-05$ & $0.5526 \mathrm{E}+03$ & $0.8598 \mathrm{E}+02$ & $0.1511 \mathrm{E}-05$ & $0.5529 \mathrm{E}+03$ & $0.8598 \mathrm{E}+02$ \\
18.0 & $0.1420 \mathrm{E}-05$ & $0.5823 \mathrm{E}+03$ & $0.8742 \mathrm{E}+02$ & $0.1422 \mathrm{E}-05$ & $0.5826 \mathrm{E}+03$ & $0.8742 \mathrm{E}+02$ \\
19.8 & $0.1344 \mathrm{E}-05$ & $0.6106 \mathrm{E}+03$ & $0.8864 \mathrm{E}+02$ & $0.1347 \mathrm{E}-05$ & $0.6109 \mathrm{E}+03$ & $0.8864 \mathrm{E}+02$ \\
21.6 & $0.1279 \mathrm{E}-05$ & $0.6376 \mathrm{E}+03$ & $0.8968 \mathrm{E}+02$ & $0.1282 \mathrm{E}-05$ & $0.6379 \mathrm{E}+03$ & $0.8968 \mathrm{E}+02$ \\
23.4 & $0.1223 \mathrm{E}-05$ & $0.6635 \mathrm{E}+03$ & $0.9058 \mathrm{E}+02$ & $0.1225 \mathrm{E}-05$ & $0.6638 \mathrm{E}+03$ & $0.9058 \mathrm{E}+02$ \\
25.2 & $0.1173 \mathrm{E}-05$ & $0.6884 \mathrm{E}+03$ & $0.9137 \mathrm{E}+02$ & $0.1175 \mathrm{E}-05$ & $0.6888 \mathrm{E}+03$ & $0.9137 \mathrm{E}+02$ \\
27.0 & $0.1128 \mathrm{E}-05$ & $0.7125 \mathrm{E}+03$ & $0.9206 \mathrm{E}+02$ & $0.1130 \mathrm{E}-05$ & $0.7128 \mathrm{E}+03$ & $0.9206 \mathrm{E}+02$ \\
28.8 & $0.1089 \mathrm{E}-05$ & $0.7358 \mathrm{E}+03$ & $0.9267 \mathrm{E}+02$ & $0.1091 \mathrm{E}-05$ & $0.7361 \mathrm{E}+03$ & $0.9267 \mathrm{E}+02$ \\
30.6 & $0.1053 \mathrm{E}-05$ & $0.7583 \mathrm{E}+03$ & $0.9322 \mathrm{E}+02$ & $0.1055 \mathrm{E}-05$ & $0.7587 \mathrm{E}+03$ & $0.9322 \mathrm{E}+02$ \\
\hline
\end{tabular}


Table 28. Same as Table 18, but for case 11

\begin{tabular}{|r|c|c|c|c|c|c|}
\hline $\begin{array}{c}\mathrm{x} \\
(\mathrm{km})\end{array}$ & $\begin{array}{c}\text { Dose (NS) } \\
(\mathrm{rem})\end{array}$ & $\begin{array}{c}\sigma_{\mathrm{y}}(\mathrm{NS}) \\
(\mathrm{m})\end{array}$ & $\begin{array}{c}\sigma_{\mathrm{z}}(\mathrm{NS}) \\
(\mathrm{m})\end{array}$ & $\begin{array}{c}\text { Dose }(\mathrm{AS}) \\
(\mathrm{rem})\end{array}$ & $\begin{array}{c}\sigma_{\mathrm{y}}(\mathrm{AS}) \\
(\mathrm{m})\end{array}$ & $\begin{array}{c}\sigma_{\mathrm{z}}(\mathrm{AS}) \\
(\mathrm{m})\end{array}$ \\
\hline 1.8 & $0.1999 \mathrm{E}-05$ & $0.4152 \mathrm{E}+02$ & $0.2175 \mathrm{E}+02$ & $0.2012 \mathrm{E}-05$ & $0.4154 \mathrm{E}+02$ & $0.2175 \mathrm{E}+02$ \\
3.6 & $0.6174 \mathrm{E}-05$ & $0.6783 \mathrm{E}+02$ & $0.3074 \mathrm{E}+02$ & $0.6198 \mathrm{E}-05$ & $0.6786 \mathrm{E}+02$ & $0.3074 \mathrm{E}+02$ \\
5.4 & $0.6675 \mathrm{E}-05$ & $0.9143 \mathrm{E}+02$ & $0.3603 \mathrm{E}+02$ & $0.6696 \mathrm{E}-05$ & $0.9148 \mathrm{E}+02$ & $0.3603 \mathrm{E}+02$ \\
7.2 & $0.6248 \mathrm{E}-05$ & $0.1134 \mathrm{E}+03$ & $0.3950 \mathrm{E}+02$ & $0.6266 \mathrm{E}-05$ & $0.1135 \mathrm{E}+03$ & $0.3950 \mathrm{E}+02$ \\
9.0 & $0.5692 \mathrm{E}-05$ & $0.1342 \mathrm{E}+03$ & $0.4197 \mathrm{E}+02$ & $0.5707 \mathrm{E}-05$ & $0.1343 \mathrm{E}+03$ & $0.4197 \mathrm{E}+02$ \\
10.8 & $0.5230 \mathrm{E}-05$ & $0.1526 \mathrm{E}+03$ & $0.4380 \mathrm{E}+02$ & $0.5244 \mathrm{E}-05$ & $0.1527 \mathrm{E}+03$ & $0.4380 \mathrm{E}+02$ \\
12.6 & $0.4987 \mathrm{E}-05$ & $0.1646 \mathrm{E}+03$ & $0.4522 \mathrm{E}+02$ & $0.5000 \mathrm{E}-05$ & $0.1647 \mathrm{E}+03$ & $0.4522 \mathrm{E}+02$ \\
14.4 & $0.4761 \mathrm{E}-05$ & $0.1757 \mathrm{E}+03$ & $0.4636 \mathrm{E}+02$ & $0.4773 \mathrm{E}-05$ & $0.1758 \mathrm{E}+03$ & $0.4636 \mathrm{E}+02$ \\
16.2 & $0.4556 \mathrm{E}-05$ & $0.1862 \mathrm{E}+03$ & $0.4728 \mathrm{E}+02$ & $0.4567 \mathrm{E}-05$ & $0.1863 \mathrm{E}+03$ & $0.4728 \mathrm{E}+02$ \\
18.0 & $0.4370 \mathrm{E}-05$ & $0.1961 \mathrm{E}+03$ & $0.4805 \mathrm{E}+02$ & $0.4381 \mathrm{E}-05$ & $0.1962 \mathrm{E}+03$ & $0.4805 \mathrm{E}+02$ \\
19.8 & $0.4203 \mathrm{E}-05$ & $0.2056 \mathrm{E}+03$ & $0.4870 \mathrm{E}+02$ & $0.4213 \mathrm{E}-05$ & $0.2057 \mathrm{E}+03$ & $0.4870 \mathrm{E}+02$ \\
21.6 & $0.4052 \mathrm{E}-05$ & $0.2146 \mathrm{E}+03$ & $0.4925 \mathrm{E}+02$ & $0.4061 \mathrm{E}-05$ & $0.2147 \mathrm{E}+03$ & $0.4925 \mathrm{E}+02$ \\
23.4 & $0.3915 \mathrm{E}-05$ & $0.2232 \mathrm{E}+03$ & $0.4973 \mathrm{E}+02$ & $0.3924 \mathrm{E}-05$ & $0.2233 \mathrm{E}+03$ & $0.4973 \mathrm{E}+02$ \\
25.2 & $0.3790 \mathrm{E}-05$ & $0.2315 \mathrm{E}+03$ & $0.5015 \mathrm{E}+02$ & $0.3798 \mathrm{E}-05$ & $0.2316 \mathrm{E}+03$ & $0.5015 \mathrm{E}+02$ \\
27.0 & $0.3676 \mathrm{E}-05$ & $0.2395 \mathrm{E}+03$ & $0.5052 \mathrm{E}+02$ & $0.3684 \mathrm{E}-05$ & $0.2396 \mathrm{E}+03$ & $0.5052 \mathrm{E}+02$ \\
28.8 & $0.3571 \mathrm{E}-05$ & $0.2473 \mathrm{E}+03$ & $0.5085 \mathrm{E}+02$ & $0.3579 \mathrm{E}-05$ & $0.2474 \mathrm{E}+03$ & $0.5085 \mathrm{E}+02$ \\
30.6 & $0.3474 \mathrm{E}-05$ & $0.2548 \mathrm{E}+03$ & $0.5114 \mathrm{E}+02$ & $0.3482 \mathrm{E}-05$ & $0.2549 \mathrm{E}+03$ & $0.5114 \mathrm{E}+02$ \\
\hline
\end{tabular}

Table 29. Same as Table 18, but for case 12

\begin{tabular}{|c|c|c|c|c|c|c|}
\hline $\begin{array}{c}\mathrm{x} \\
(\mathrm{km})\end{array}$ & $\begin{array}{c}\text { Dose (NS) } \\
\text { (rem) }\end{array}$ & $\begin{array}{c}\sigma_{y}(\mathrm{NS}) \\
(\mathrm{m})\end{array}$ & $\begin{array}{c}\sigma_{z}(\mathrm{NS}) \\
(\mathrm{m})\end{array}$ & $\begin{array}{c}\text { Dose (AS) } \\
\text { (rem) }\end{array}$ & $\begin{array}{c}\sigma_{y} \text { (AS) } \\
(\mathrm{m})\end{array}$ & $\begin{array}{c}\sigma_{2} \text { (AS) } \\
(\mathrm{m})\end{array}$ \\
\hline 0.6 & $0.3205 \mathrm{E}-04$ & $0.8302 \mathrm{E}+02$ & $0.2917 \mathrm{E}+02$ & $0.3219 \mathrm{E}-04$ & $0.8306 \mathrm{E}+02$ & $0.2917 \mathrm{E}+02$ \\
\hline & $0.4249 \mathrm{E}-04$ & $0.1471 E+03$ & $608 E+02$ & $0.4259 \mathrm{E}-04$ & $0.1471 \mathrm{E}+03$ & $0.4608 E+02$ \\
\hline 1.8 & $0.3516 \mathrm{E}-04$ & $1954 E+03$ & $19 E+02$ & $0.3523 \mathrm{E}-04$ & $0.1955 E+03$ & $919 E+02$ \\
\hline 2.4 & $0.2798 \mathrm{E}-04$ & $413 E+03$ & $E+02$ & 03E-04 & $14 E+03$ & $19 E+02$ \\
\hline 3.0 & $0.2270 \mathrm{E}-04$ & $0.2850 E+03$ & $0.7980 E+02$ & $0.2274 \mathrm{E}-04$ & $0.2852 E+03$ & $0.7980 E+02$ \\
\hline 3.6 & $0.1885 \mathrm{E}-04$ & $0.3269 E+03$ & $0.8843 E+02$ & $0.1888 \mathrm{E}-04$ & $0.3271 E+03$ & $0.8843 E+02$ \\
\hline 4.2 & $0.1599 \mathrm{E}-04$ & $0.3674 E+03$ & $0.9632 E+02$ & $0.1601 \mathrm{E}-04$ & $0.3676 \mathrm{E}+03$ & $0.9632 E+02$ \\
\hline 4.8 & $0.1380 \mathrm{E}-04$ & $0.4067 E+03$ & $0.1036 E+03$ & $0.1382 \mathrm{E}-04$ & $0.4069 E+03$ & $0.1036 E+03$ \\
\hline 5.4 & 08E-04 & $0.4450 \mathrm{E}+$ & $105 E+03$ & $0.1210 \mathrm{E}-04$ & $1452 E+03$ & $.1105 E+03$ \\
\hline 6.0 & 0.1 & 0.4823 & & $2 E-04$ & $26 \mathrm{E}+03$ & $9 E+03$ \\
\hline 6.6 & $1 E-05$ & 0.5 & $0 \mathrm{E}+03$ & $5 \mathrm{E}-05$ & $2 E+03$ & $30 \mathrm{E}+03$ \\
\hline 7.2 & OE-05 & 0.5 & +03 & $62 \mathrm{E}-05$ & $51 \mathrm{E}+03$ & $38 \mathrm{E}+03$ \\
\hline 7.8 & 58E-05 & $0.5901 E+03$ & $4 E+03$ & 79E-05 & $0.5903 E+03$ & $4 E+03$ \\
\hline 8.4 & $0.7202 \mathrm{E}-05$ & $0.6247 E+03$ & $97 \mathrm{E}+03$ & $0.7212 \mathrm{E}-05$ & $0.6251 E+03$ & $0.1397 E+03$ \\
\hline 9.0 & $0.6630 \mathrm{E}-05$ & $0.6589 E$ & $49 E+03$ & $0.6639 \mathrm{E}-05$ & $0.6592 E+03$ & $0.1449 E+03$ \\
\hline 9.6 & 34E-05 & $0.6926 \mathrm{E}+$ & $98 E+03$ & $0.6142 \mathrm{E}-05$ & $0.6929 E+03$ & $0.1498 E+03$ \\
\hline 10.2 & $0.5669 \mathrm{E}-05$ & $0.7298 E+03$ & $46 E+03$ & $0.5677 \mathrm{E}-05$ & $0.7302 E+03$ & $46 E+03$ \\
\hline 10. & $0.5 ?$ & $0.7509 E$ & $3 E+03$ & $0.5380 \mathrm{E}-05$ & $512 E+03$ & \\
\hline 11 & $06 \mathrm{E}-05$ & & $8 E+03$ & $13 E-05$ & $17 E+03$ & \\
\hline 12 & $0.4864 \mathrm{E}-$ & & & & $7 E+03$ & $682 E+03$ \\
\hline 12 & 0.4 & 0.8 & $25 E+$ & $50 \mathrm{E}-05$ & $2 E+03$ & $725 E+03$ \\
\hline 13.2 & $0.4443 E-05$ & $0.8298 \mathrm{E}$ & $0.1767 E+03$ & $0.4449 \mathrm{E}-05$ & $0.8302 E+03$ & $0.1767 \mathrm{E}+03$ \\
\hline
\end{tabular}


Table 29. (cont'd)

\begin{tabular}{|c|c|c|c|c|c|c|}
\hline $\begin{array}{c}\mathbf{x} \\
(\mathrm{km})\end{array}$ & $\begin{array}{c}\text { Dose (NS) } \\
\text { (rem) }\end{array}$ & $\begin{array}{c}\sigma_{y}(\mathrm{NS}) \\
(\mathrm{m})\end{array}$ & $\begin{array}{c}\sigma_{z}(\mathrm{NS}) \\
(\mathrm{m})\end{array}$ & $\begin{array}{c}\text { Dose (AS) } \\
\text { (rem) }\end{array}$ & $\begin{array}{c}\sigma_{y}(\mathrm{AS}) \\
(\mathrm{m})\end{array}$ & $\begin{array}{c}\sigma_{2}(\mathrm{AS}) \\
(\mathrm{m})\end{array}$ \\
\hline 13.8 & $0.4259 \mathrm{E}-05$ & $0.8484 E+03$ & $0.1808 \mathrm{E}+03$ & $0.4265 \mathrm{E}-05$ & $0.8488 \mathrm{E}+03$ & $0.1808 \mathrm{E}+03$ \\
\hline & $0.4089 \mathrm{E}-05$ & $0.8665 \mathrm{E}+03$ & $0.1848 \mathrm{E}+03$ & $0.4095 \mathrm{E}-05$ & $0.8670 \mathrm{E}+03$ & $0.1848 E+03$ \\
\hline 15.0 & & & & & & \\
\hline 15. & $3788 \mathrm{E}-05$ & $18 \mathrm{E}+03$ & $0.1925 E+03$ & $0.3793 \mathrm{E}-05$ & $0.9023 E+03$ & $25 \mathrm{E}+0$ \\
\hline & $0.3653 \mathrm{E}-05$ & $89 E+03$ & $0.1963 \mathrm{E}+03$ & $558 \mathrm{E}-05$ & $0.9194 E+03$ & \\
\hline 16.8 & $0.3527 \mathrm{E}-05$ & & & & & \\
\hline 17.4 & $0.3410 \mathrm{E}-05$ & $0.9522 E+03$ & $0.2036 E+03$ & $0.3415 \mathrm{E}-05$ & $0.9527 E+03$ & $6 \mathrm{E}+03$ \\
\hline 18.0 & $1 \mathrm{E}-05$ & $0.9685 \mathrm{E}+03$ & $0.2071 \mathrm{E}+03$ & $0.3305 \mathrm{E}-05$ & $690 \mathrm{E}+03$ & \\
\hline 18.6 & -05 & & & & & \\
\hline 19.2 & $1 \mathrm{E}-05$ & $0 E+04$ & $1 E+03$ & $5 \mathrm{E}-05$ & $01 \mathrm{E}+04$ & \\
\hline 19.8 & .05 & $6 E+04$ & $\mathrm{E}+03$ & $4 \mathrm{E}-05$ & $6 E+04$ & \\
\hline & & & & & & \\
\hline 21.0 & $0.2 \varepsilon$ & & & & & \\
\hline 21.6 & 05 & & & 0.2 & & \\
\hline 22.2 & & & & & & \\
\hline & E-05 & 0.10 & & 0.262 & & \\
\hline 23.4 & & & & & & \\
\hline & & & & & & \\
\hline & E-05 & & & $2 \mathrm{E}-05$ & & \\
\hline 25. & & & & & & \\
\hline & & & & & & \\
\hline & $0.2276 \mathrm{E}-05$ & & & 0.2 & & \\
\hline & $0.2227 \mathrm{E}-05$ & & & $0.2230 \mathrm{E}$ & & \\
\hline & & & & & & \\
\hline & E-05 & 0.12 & 0.26 & $0.2137 \mathrm{E}-05$ & 0.12 & \\
\hline & 0.2 & & & $4 \mathrm{E}-05$ & 0.1 & \\
\hline & & & & $52 \mathrm{E}-05$ & 0.12 & \\
\hline & $0.2009 \mathrm{E}-05$ & $0.1249 \mathrm{E}$ & $0.2684 \mathrm{E}$ & $0.2012 \mathrm{E}-05$ & $0.1250 \mathrm{E}+0$ & $0.2684 \mathrm{E}+\mathrm{c}$ \\
\hline
\end{tabular}


Table 30. Same as Table 18, but for case 13

\begin{tabular}{|c|c|c|c|c|c|c|}
\hline $\begin{array}{c}\mathrm{x} \\
(\mathrm{km})\end{array}$ & $\begin{array}{c}\text { Dose (NS) } \\
(\mathrm{rem})\end{array}$ & $\begin{array}{c}\sigma_{\mathrm{y}}(\mathrm{NS}) \\
(\mathrm{m})\end{array}$ & $\begin{array}{c}\sigma_{\mathrm{z}}(\mathrm{NS}) \\
(\mathrm{m})\end{array}$ & $\begin{array}{c}\text { Dose (AS) } \\
(\mathrm{rem})\end{array}$ & $\begin{array}{c}\sigma_{\mathrm{y}}(\mathrm{AS}) \\
(\mathrm{m})\end{array}$ & $\begin{array}{c}\sigma_{\mathrm{z}}(\mathrm{AS}) \\
(\mathrm{m})\end{array}$ \\
\hline 1.8 & $0.1172 \mathrm{E}-04$ & $0.1954 \mathrm{E}+03$ & $0.5919 \mathrm{E}+02$ & $0.1174 \mathrm{E}-04$ & $0.1955 \mathrm{E}+03$ & $0.5919 \mathrm{E}+02$ \\
3.6 & $0.6285 \mathrm{E}-05$ & $0.3269 \mathrm{E}+03$ & $0.8843 \mathrm{E}+02$ & $0.6295 \mathrm{E}-05$ & $0.3271 \mathrm{E}+03$ & $0.8843 \mathrm{E}+02$ \\
5.4 & $0.4027 \mathrm{E}-05$ & $0.4450 \mathrm{E}+03$ & $0.1105 \mathrm{E}+03$ & $0.4033 \mathrm{E}-05$ & $0.4452 \mathrm{E}+03$ & $0.1105 \mathrm{E}+03$ \\
7.2 & $0.2883 \mathrm{E}-05$ & $0.5548 \mathrm{E}+03$ & $0.1288 \mathrm{E}+03$ & $0.2888 \mathrm{E}-05$ & $0.5551 \mathrm{E}+03$ & $0.1288 \mathrm{E}+03$ \\
9.0 & $0.2210 \mathrm{E}-05$ & $0.6589 \mathrm{E}+03$ & $0.1449 \mathrm{E}+03$ & $0.2213 \mathrm{E}-05$ & $0.6592 \mathrm{E}+03$ & $0.1449 \mathrm{E}+03$ \\
10.8 & $0.1791 \mathrm{E}-05$ & $0.7509 \mathrm{E}+03$ & $0.1593 \mathrm{E}+03$ & $0.1793 \mathrm{E}-05$ & $0.7512 \mathrm{E}+03$ & $0.1593 \mathrm{E}+03$ \\
12.6 & $0.1548 \mathrm{E}-05$ & $0.8108 \mathrm{E}+03$ & $0.1725 \mathrm{E}+03$ & $0.1550 \mathrm{E}-05$ & $0.8112 \mathrm{E}+03$ & $0.1725 \mathrm{E}+03$ \\
14.4 & $0.1363 \mathrm{E}-05$ & $0.8665 \mathrm{E}+03$ & $0.1848 \mathrm{E}+03$ & $0.1365 \mathrm{E}-05$ & $0.8670 \mathrm{E}+03$ & $0.1848 \mathrm{E}+03$ \\
16.2 & $0.1218 \mathrm{E}-05$ & $0.9189 \mathrm{E}+03$ & $0.1963 \mathrm{E}+03$ & $0.1219 \mathrm{E}-05$ & $0.9194 \mathrm{E}+03$ & $0.1963 \mathrm{E}+03$ \\
18.0 & $0.1100 \mathrm{E}-05$ & $0.9685 \mathrm{E}+03$ & $0.2071 \mathrm{E}+03$ & $0.1102 \mathrm{E}-05$ & $0.9690 \mathrm{E}+03$ & $0.2071 \mathrm{E}+03$ \\
19.8 & $0.1003 \mathrm{E}-05$ & $0.1016 \mathrm{E}+04$ & $0.2175 \mathrm{E}+03$ & $0.1005 \mathrm{E}-05$ & $0.1016 \mathrm{E}+04$ & $0.2175 \mathrm{E}+03$ \\
21.6 & $0.9223 \mathrm{E}-06$ & $0.1061 \mathrm{E}+04$ & $0.2273 \mathrm{E}+03$ & $0.9235 \mathrm{E}-06$ & $0.1061 \mathrm{E}+04$ & $0.2273 \mathrm{E}+03$ \\
23.4 & $0.8533 \mathrm{E}-06$ & $0.1104 \mathrm{E}+04$ & $0.2367 \mathrm{E}+03$ & $0.8545 \mathrm{E}-06$ & $0.1104 \mathrm{E}+04$ & $0.2367 \mathrm{E}+03$ \\
25.2 & $0.7940 \mathrm{E}-06$ & $0.1145 \mathrm{E}+04$ & $0.2458 \mathrm{E}+03$ & $0.7950 \mathrm{E}-06$ & $0.1146 \mathrm{E}+04$ & $0.2458 \mathrm{E}+03$ \\
27.0 & $0.7423 \mathrm{E}-06$ & $0.1185 \mathrm{E}+04$ & $0.2545 \mathrm{E}+03$ & $0.7433 \mathrm{E}-06$ & $0.1186 \mathrm{E}+04$ & $0.2545 \mathrm{E}+03$ \\
28.8 & $0.6970 \mathrm{E}-06$ & $0.1224 \mathrm{E}+04$ & $0.2630 \mathrm{E}+03$ & $0.6979 \mathrm{E}-06$ & $0.1225 \mathrm{E}+04$ & $0.2630 \mathrm{E}+03$ \\
30.6 & $0.6569 \mathrm{E}-06$ & $0.1262 \mathrm{E}+04$ & $0.2711 \mathrm{E}+03$ & $0.6578 \mathrm{E}-06$ & $0.1262 \mathrm{E}+04$ & $0.2711 \mathrm{E}+03$ \\
\hline
\end{tabular}

Table 31. Same as Table 18, but for case 14

\begin{tabular}{|c|c|c|c|c|c|c|}
\hline $\begin{array}{c}\mathrm{x} \\
(\mathrm{km})\end{array}$ & $\begin{array}{c}\text { Dose }(\mathrm{NS}) \\
(\mathrm{rem})\end{array}$ & $\begin{array}{c}\sigma_{\mathrm{y}}(\mathrm{NS}) \\
(\mathrm{m})\end{array}$ & $\begin{array}{c}\sigma_{\mathrm{z}}(\mathrm{NS}) \\
(\mathrm{m})\end{array}$ & $\begin{array}{c}\text { Dose }(\mathrm{AS}) \\
(\mathrm{rem})\end{array}$ & $\begin{array}{c}\sigma_{\mathrm{y}}(\mathrm{AS}) \\
(\mathrm{m})\end{array}$ & $\begin{array}{c}\sigma_{\mathrm{z}}(\mathrm{AS}) \\
(\mathrm{m})\end{array}$ \\
\hline 1.5 & $0.7846 \mathrm{E}-05$ & $0.1715 \mathrm{E}+03$ & $0.5297 \mathrm{E}+02$ & $0.7863 \mathrm{E}-05$ & $0.1715 \mathrm{E}+03$ & $0.5297 \mathrm{E}+02$ \\
3.0 & $0.4540 \mathrm{E}-05$ & $0.2850 \mathrm{E}+03$ & $0.7980 \mathrm{E}+02$ & $0.4548 \mathrm{E}-05$ & $0.2852 \mathrm{E}+03$ & $0.7980 \mathrm{E}+02$ \\
4.5 & $0.2965 \mathrm{E}-05$ & $0.3872 \mathrm{E}+03$ & $0.1000 \mathrm{E}+03$ & $0.2969 \mathrm{E}-05$ & $0.3874 \mathrm{E}+03$ & $0.1000 \mathrm{E}+03$ \\
6.0 & $0.2141 \mathrm{E}-05$ & $0.4823 \mathrm{E}+03$ & $0.1169 \mathrm{E}+03$ & $0.2144 \mathrm{E}-05$ & $0.4826 \mathrm{E}+03$ & $0.1169 \mathrm{E}+03$ \\
7.5 & $0.1649 \mathrm{E}-05$ & $0.5725 \mathrm{E}+03$ & $0.1316 \mathrm{E}+03$ & $0.1651 \mathrm{E}-05$ & $0.5728 \mathrm{E}+03$ & $0.1316 \mathrm{E}+03$ \\
9.0 & $0.1326 \mathrm{E}-05$ & $0.6589 \mathrm{E}+03$ & $0.1449 \mathrm{E}+03$ & $0.1328 \mathrm{E}-05$ & $0.6592 \mathrm{E}+03$ & $0.1449 \mathrm{E}+03$ \\
10.5 & $0.1103 \mathrm{E}-05$ & $0.7404 \mathrm{E}+03$ & $0.1570 \mathrm{E}+03$ & $0.1105 \mathrm{E}-05$ & $0.7408 \mathrm{E}+03$ & $0.1570 \mathrm{E}+03$ \\
12.0 & $0.9728 \mathrm{E}-06$ & $0.7913 \mathrm{E}+03$ & $0.1682 \mathrm{E}+03$ & $0.9742 \mathrm{E}-06$ & $0.7917 \mathrm{E}+03$ & $0.1682 \mathrm{E}+03$ \\
13.5 & $0.8698 \mathrm{E}-06$ & $0.8391 \mathrm{E}+03$ & $0.1788 \mathrm{E}+03$ & $0.8710 \mathrm{E}-06$ & $0.8396 \mathrm{E}+03$ & $0.1788 \mathrm{E}+03$ \\
15.0 & $0.7866 \mathrm{E}-06$ & $0.8844 \mathrm{E}+03$ & $0.1887 \mathrm{E}+03$ & $0.7876 \mathrm{E}-06$ & $0.8848 \mathrm{E}+03$ & $0.1887 \mathrm{E}+03$ \\
16.5 & $0.7178 \mathrm{E}-06$ & $0.9274 \mathrm{E}+03$ & $0.1981 \mathrm{E}+03$ & $0.7188 \mathrm{E}-06$ & $0.9278 \mathrm{E}+03$ & $0.1981 \mathrm{E}+03$ \\
18.0 & $0.6601 \mathrm{E}-06$ & $0.9685 \mathrm{E}+03$ & $0.2071 \mathrm{E}+03$ & $0.6610 \mathrm{E}-06$ & $0.9690 \mathrm{E}+03$ & $0.2071 \mathrm{E}+03$ \\
19.5 & $0.6110 \mathrm{E}-06$ & $0.1008 \mathrm{E}+04$ & $0.2158 \mathrm{E}+03$ & $0.6118 \mathrm{E}-06$ & $0.1008 \mathrm{E}+04$ & $0.2158 \mathrm{E}+03$ \\
21.0 & $0.5687 \mathrm{E}-06$ & $0.1046 \mathrm{E}+04$ & $0.2241 \mathrm{E}+03$ & $0.5695 \mathrm{E}-06$ & $0.1046 \mathrm{E}+04$ & $0.2241 \mathrm{E}+03$ \\
22.5 & $0.5319 \mathrm{E}-06$ & $0.1082 \mathrm{E}+04$ & $0.2321 \mathrm{E}+03$ & $0.5326 \mathrm{E}-06$ & $0.1083 \mathrm{E}+04$ & $0.2321 \mathrm{E}+03$ \\
24.0 & $0.4996 \mathrm{E}-06$ & $0.1118 \mathrm{E}+04$ & $0.2398 \mathrm{E}+03$ & $0.5002 \mathrm{E}-06$ & $0.1118 \mathrm{E}+04$ & $0.2398 \mathrm{E}+03$ \\
25.5 & $0.4709 \mathrm{E}-06$ & $0.1152 \mathrm{E}+04$ & $0.2473 \mathrm{E}+03$ & $0.4715 \mathrm{E}-06$ & $0.1153 \mathrm{E}+04$ & $0.2473 \mathrm{E}+03$ \\
27.0 & $0.4454 \mathrm{E}-06$ & $0.1185 \mathrm{E}+04$ & $0.2545 \mathrm{E}+03$ & $0.4460 \mathrm{E}-06$ & $0.1186 \mathrm{E}+04$ & $0.2545 \mathrm{E}+03$ \\
28.5 & $0.4225 \mathrm{E}-06$ & $0.1218 \mathrm{E}+04$ & $0.2616 \mathrm{E}+03$ & $0.4231 \mathrm{E}-06$ & $0.1218 \mathrm{E}+04$ & $0.2616 \mathrm{E}+03$ \\
30.0 & $0.4018 \mathrm{E}-06$ & $0.1249 \mathrm{E}+04$ & $0.2684 \mathrm{E}+03$ & $0.4024 \mathrm{E}-06$ & $0.1250 \mathrm{E}+04$ & $0.2684 \mathrm{E}+03$ \\
\hline
\end{tabular}


Table 32. Same as Table 18 , but for case $\mathbf{1 5}$

\begin{tabular}{|r|c|c|c|c|c|c|}
\hline $\begin{array}{c}\mathbf{x} \\
(\mathrm{km})\end{array}$ & $\begin{array}{c}\text { Dose }(\mathrm{NS}) \\
(\mathrm{rem})\end{array}$ & $\begin{array}{c}\sigma_{\mathrm{y}}(\mathrm{NS}) \\
(\mathrm{m})\end{array}$ & $\begin{array}{c}\sigma_{\mathrm{z}}(\mathrm{NS}) \\
(\mathrm{m})\end{array}$ & $\begin{array}{c}\text { Dose }(\mathrm{AS}) \\
(\mathrm{rem})\end{array}$ & $\begin{array}{c}\sigma_{\mathrm{y}}(\mathrm{AS}) \\
(\mathrm{m})\end{array}$ & $\begin{array}{c}\sigma_{\mathrm{z}}(\mathrm{AS}) \\
(\mathrm{m})\end{array}$ \\
\hline 1.8 & $0.3516 \mathrm{E}-05$ & $0.1954 \mathrm{E}+03$ & $0.5919 \mathrm{E}+02$ & $0.3523 \mathrm{E}-05$ & $0.1955 \mathrm{E}+03$ & $0.5919 \mathrm{E}+02$ \\
3.6 & $0.1885 \mathrm{E}-05$ & $0.3269 \mathrm{E}+03$ & $0.8843 \mathrm{E}+02$ & $0.1888 \mathrm{E}-05$ & $0.3271 \mathrm{E}+03$ & $0.8843 \mathrm{E}+02$ \\
5.4 & $0.1208 \mathrm{E}-05$ & $0.4450 \mathrm{E}+03$ & $0.1105 \mathrm{E}+03$ & $0.1210 \mathrm{E}-05$ & $0.4452 \mathrm{E}+03$ & $0.1105 \mathrm{E}+03$ \\
7.2 & $0.8650 \mathrm{E}-06$ & $0.5548 \mathrm{E}+03$ & $0.1288 \mathrm{E}+03$ & $0.8663 \mathrm{E}-06$ & $0.5551 \mathrm{E}+03$ & $0.1288 \mathrm{E}+03$ \\
9 & $0.6630 \mathrm{E}-06$ & $0.6589 \mathrm{E}+03$ & $0.1449 \mathrm{E}+03$ & $0.6640 \mathrm{E}-06$ & $0.6592 \mathrm{E}+03$ & $0.1449 \mathrm{E}+03$ \\
10.8 & $0.5373 \mathrm{E}-06$ & $0.7509 \mathrm{E}+03$ & $0.1593 \mathrm{E}+03$ & $0.5380 \mathrm{E}-06$ & $0.7512 \mathrm{E}+03$ & $0.1593 \mathrm{E}+03$ \\
12.6 & $0.4644 \mathrm{E}-06$ & $0.8108 \mathrm{E}+03$ & $0.1725 \mathrm{E}+03$ & $0.4651 \mathrm{E}-06$ & $0.8112 \mathrm{E}+03$ & $0.1725 \mathrm{E}+03$ \\
14.4 & $0.4089 \mathrm{E}-06$ & $0.8665 \mathrm{E}+03$ & $0.1848 \mathrm{E}+03$ & $0.4095 \mathrm{E}-06$ & $0.8670 \mathrm{E}+03$ & $0.1848 \mathrm{E}+03$ \\
16.2 & $0.3653 \mathrm{E}-06$ & $0.9189 \mathrm{E}+03$ & $0.1963 \mathrm{E}+03$ & $0.3658 \mathrm{E}-06$ & $0.9194 \mathrm{E}+03$ & $0.1963 \mathrm{E}+03$ \\
18.0 & $0.3301 \mathrm{E}-06$ & $0.9685 \mathrm{E}+03$ & $0.2071 \mathrm{E}+03$ & $0.3305 \mathrm{E}-06$ & $0.9690 \mathrm{E}+03$ & $0.2071 \mathrm{E}+03$ \\
19.8 & $0.3010 \mathrm{E}-06$ & $0.1016 \mathrm{E}+04$ & $0.2175 \mathrm{E}+03$ & $0.3014 \mathrm{E}-06$ & $0.1016 \mathrm{E}+04$ & $0.2175 \mathrm{E}+03$ \\
21.6 & $0.2767 \mathrm{E}-06$ & $0.1061 \mathrm{E}+04$ & $0.2273 \mathrm{E}+03$ & $0.2771 \mathrm{E}-06$ & $0.1061 \mathrm{E}+04$ & $0.2273 \mathrm{E}+03$ \\
23.4 & $0.2560 \mathrm{E}-06$ & $0.1104 \mathrm{E}+04$ & $0.2367 \mathrm{E}+03$ & $0.2563 \mathrm{E}-06$ & $0.1104 \mathrm{E}+04$ & $0.2367 \mathrm{E}+03$ \\
25.2 & $0.2382 \mathrm{E}-06$ & $0.1145 \mathrm{E}+04$ & $0.2458 \mathrm{E}+03$ & $0.2385 \mathrm{E}-06$ & $0.1146 \mathrm{E}+04$ & $0.2458 \mathrm{E}+03$ \\
27.0 & $0.2227 \mathrm{E}-06$ & $0.1185 \mathrm{E}+04$ & $0.2545 \mathrm{E}+03$ & $0.2230 \mathrm{E}-06$ & $0.1186 \mathrm{E}+04$ & $0.2545 \mathrm{E}+03$ \\
28.8 & $0.2091 \mathrm{E}-06$ & $0.1224 \mathrm{E}+04$ & $0.2630 \mathrm{E}+03$ & $0.2094 \mathrm{E}-06$ & $0.1225 \mathrm{E}+04$ & $0.2630 \mathrm{E}+03$ \\
30.6 & $0.1971 \mathrm{E}-06$ & $0.1262 \mathrm{E}+04$ & $0.2711 \mathrm{E}+03$ & $0.1973 \mathrm{E}-06$ & $0.1262 \mathrm{E}+04$ & $0.2711 \mathrm{E}+03$ \\
\hline
\end{tabular}


Table 33. Comparison of the analytic solution (AS), Eq. (9), and the numerical results (NS) calculated by PUFF/PLUME for puff using the input parameters given for case 1 (default case) listed in Tables 1 and 2

\begin{tabular}{|r|c|c|c|c|c|c|}
\hline $\begin{array}{c}\mathrm{x} \\
(\mathrm{km})\end{array}$ & $\begin{array}{c}\text { Dose (NS) } \\
(\mathrm{rem})\end{array}$ & $\begin{array}{c}\sigma_{\mathrm{y}}(\mathrm{NS}) \\
(\mathrm{m})\end{array}$ & $\begin{array}{c}\sigma_{\mathrm{z}}(\mathrm{NS}) \\
(\mathrm{m})\end{array}$ & $\begin{array}{c}\text { Dose }(\mathrm{AS}) \\
(\mathrm{rem})\end{array}$ & $\begin{array}{c}\sigma_{\mathrm{y}}(\mathrm{AS}) \\
(\mathrm{m})\end{array}$ & $\begin{array}{c}\sigma_{\mathrm{z}}(\mathrm{AS}) \\
(\mathrm{m})\end{array}$ \\
\hline 1.8 & $0.2561 \mathrm{E}-05$ & $0.8940 \mathrm{E}+02$ & $0.5919 \mathrm{E}+02$ & $0.2561 \mathrm{E}-05$ & $0.8944 \mathrm{E}+02$ & $0.5919 \mathrm{E}+02$ \\
3.6 & $0.1169 \mathrm{E}-05$ & $0.1757 \mathrm{E}+03$ & $0.8843 \mathrm{E}+02$ & $0.1169 \mathrm{E}-05$ & $0.1758 \mathrm{E}+03$ & $0.8843 \mathrm{E}+02$ \\
5.4 & $0.6835 \mathrm{E}-06$ & $0.2621 \mathrm{E}+03$ & $0.1105 \mathrm{E}+03$ & $0.6833 \mathrm{E}-06$ & $0.2622 \mathrm{E}+03$ & $0.1105 \mathrm{E}+03$ \\
7.2 & $0.4590 \mathrm{E}-06$ & $0.3484 \mathrm{E}+03$ & $0.1288 \mathrm{E}+03$ & $0.4588 \mathrm{E}-06$ & $0.3486 \mathrm{E}+03$ & $0.1288 \mathrm{E}+03$ \\
9.0 & $0.3348 \mathrm{E}-06$ & $0.4348 \mathrm{E}+03$ & $0.1449 \mathrm{E}+03$ & $0.3347 \mathrm{E}-06$ & $0.4350 \mathrm{E}+03$ & $0.1449 \mathrm{E}+03$ \\
10.8 & $0.2580 \mathrm{E}-06$ & $0.5211 \mathrm{E}+03$ & $0.1593 \mathrm{E}+03$ & $0.2579 \mathrm{E}-06$ & $0.5214 \mathrm{E}+03$ & $0.1593 \mathrm{E}+03$ \\
12.6 & $0.2066 \mathrm{E}-06$ & $0.6075 \mathrm{E}+03$ & $0.1725 \mathrm{E}+03$ & $0.2065 \mathrm{E}-06$ & $0.6078 \mathrm{E}+03$ & $0.1725 \mathrm{E}+03$ \\
14.4 & $0.1702 \mathrm{E}-06$ & $0.6938 \mathrm{E}+03$ & $0.1848 \mathrm{E}+03$ & $0.1701 \mathrm{E}-06$ & $0.6942 \mathrm{E}+03$ & $0.1848 \mathrm{E}+03$ \\
16.2 & $0.1434 \mathrm{E}-06$ & $0.7802 \mathrm{E}+03$ & $0.1963 \mathrm{E}+03$ & $0.1433 \mathrm{E}-06$ & $0.7806 \mathrm{E}+03$ & $0.1963 \mathrm{E}+03$ \\
18.0 & $0.1229 \mathrm{E}-06$ & $0.8665 \mathrm{E}+03$ & $0.2071 \mathrm{E}+03$ & $0.1229 \mathrm{E}-06$ & $0.8670 \mathrm{E}+03$ & $0.2071 \mathrm{E}+03$ \\
19.8 & $0.1069 \mathrm{E}-06$ & $0.9529 \mathrm{E}+03$ & $0.2175 \mathrm{E}+03$ & $0.1069 \mathrm{E}-06$ & $0.9534 \mathrm{E}+03$ & $0.2175 \mathrm{E}+03$ \\
21.6 & $0.9411 \mathrm{E}-07$ & $0.1039 \mathrm{E}+04$ & $0.2273 \mathrm{E}+03$ & $0.9407 \mathrm{E}-07$ & $0.1040 \mathrm{E}+04$ & $0.2273 \mathrm{E}+03$ \\
23.4 & $0.8532 \mathrm{E}-07$ & $0.1104 \mathrm{E}+04$ & $0.2367 \mathrm{E}+03$ & $0.8528 \mathrm{E}-07$ & $0.1104 \mathrm{E}+04$ & $0.2367 \mathrm{E}+03$ \\
25.2 & $0.7938 \mathrm{E}-07$ & $0.1145 \mathrm{E}+04$ & $0.2458 \mathrm{E}+03$ & $0.7934 \mathrm{E}-07$ & $0.1146 \mathrm{E}+04$ & $0.2458 \mathrm{E}+03$ \\
27.0 & $0.7422 \mathrm{E}-07$ & $0.1185 \mathrm{E}+04$ & $0.2545 \mathrm{E}+03$ & $0.7418 \mathrm{E}-07$ & $0.1186 \mathrm{E}+04$ & $0.2545 \mathrm{E}+03$ \\
28.8 & $0.6969 \mathrm{E}-07$ & $0.1224 \mathrm{E}+04$ & $0.2630 \mathrm{E}+03$ & $0.6965 \mathrm{E}-07$ & $0.1225 \mathrm{E}+04$ & $0.2630 \mathrm{E}+03$ \\
30.6 & $0.6568 \mathrm{E}-07$ & $0.1262 \mathrm{E}+04$ & $0.2711 \mathrm{E}+03$ & $0.6564 \mathrm{E}-07$ & $0.1262 \mathrm{E}+04$ & $0.2711 \mathrm{E}+03$ \\
\hline
\end{tabular}

Table 34. Same as Table 33, but for case 2 and analytic solution given by Eq. (7)

\begin{tabular}{|c|c|c|c|c|c|c|}
\hline $\begin{array}{c}\mathrm{x} \\
(\mathrm{km})\end{array}$ & $\begin{array}{c}\text { Conc. (NS) } \\
(\mathrm{ppm})\end{array}$ & $\begin{array}{c}\sigma_{y}(\mathrm{NS}) \\
(\mathrm{m})\end{array}$ & $\begin{array}{c}\sigma_{\mathrm{z}}(\mathrm{NS}) \\
(\mathrm{m})\end{array}$ & $\begin{array}{l}\text { Conc. (AS) } \\
\text { (ppm) }\end{array}$ & $\begin{array}{c}\sigma_{y}(\mathrm{AS}) \\
(\mathrm{m})\end{array}$ & $\begin{array}{c}\sigma_{\mathrm{z}}(\hat{\Lambda S}) \\
(\mathrm{m})\end{array}$ \\
\hline 1.8 & $0.3643 \mathrm{E}-00$ & $0.8940 \mathrm{E}+02$ & $0.5919 E+02$ & $0.3642 E+00$ & $0.8944 \mathrm{E}+02$ & $0.5919 \mathrm{E}+02$ \\
\hline 3.6 & $0.8458 \mathrm{E}-01$ & $0.1757 E+03$ & $0.8843 E+02$ & $0.8453 E-01$ & $0.1758 \mathrm{E}+03$ & $0.8843 E+02$ \\
\hline 5.4 & $0.3316 \mathrm{E}-01$ & $0.2621 E+03$ & $0.1105 E+03$ & $0.3314 \mathrm{E}-01$ & $0.2622 E+03$ & $0.1105 E+03$ \\
\hline 7.2 & $0.1675 \mathrm{E}-01$ & $0.3484 E+03$ & $0.1288 E+03$ & $0.1674 \mathrm{E}-01$ & $0.3486 \mathrm{E}+03$ & $0.1288 E+03$ \\
\hline 9.0 & $0.9794 \mathrm{E}-02$ & $0.4348 E+03$ & $0.1449 E+03$ & $0.9785 \mathrm{E}-02$ & $0.4350 E+03$ & \\
\hline 10. & $5 E-02$ & $1 E+03$ & $3 E+03$ & E-02 & $14 E+03$ & \\
\hline 12.6 & -02 & $\bar{E}+03$ & $5 E+$ & OE-02 & $3 E+03$ & 03 \\
\hline 14.4 & $\mathrm{OE}-02$ & $E+03$ & & 7E-02 & $E+03$ & \\
\hline 16.2 & 7E-02 & $E+03$ & & E-02 & & \\
\hline 18.0 & $4 \bar{E}-02$ & $5 E+03$ & 0 & E-02 & $570 E+03$ & +03 \\
\hline 19.8 & $7 \mathrm{E}-02$ & $9 E+03$ & & $5 \mathrm{E}-02$ & $E+03$ & \\
\hline 21.6 & $52 \mathrm{E}-02$ & $39 E+04$ & 0.2 & $1 \mathrm{E}-02$ & $\mathrm{OE}+$ & $73 E+03$ \\
\hline & $30 \mathrm{E}-03$ & $04 E+04$ & $67 \mathrm{E}$ & $21 E-03$ & $4 E+04$ & $367 E+03$ \\
\hline 25 & $14 E-03$ & $5 E+04$ & 0.2 & $6 E-03$ & $46 \mathrm{E}+04$ & \\
\hline & $62 \mathrm{E}-03$ & $35 E+04$ & 0.2 & $5 E-03$ & $86 E+04$ & \\
\hline & $0.7 i$ & $24 E+04$ & 0.2 & & & \\
\hline & $0 . \epsilon^{\prime} 19 \mathrm{E}-03$ & $0.1262 E+04$ & & & & 0.21112 \\
\hline
\end{tabular}


Table 35. Same as Table 33, but for case 3

\begin{tabular}{|r|c|c|c|c|c|c|}
\hline $\begin{array}{c}\mathrm{x} \\
(\mathrm{km})\end{array}$ & $\begin{array}{c}\text { Dose }(\mathrm{NS}) \\
(\mathrm{rem})\end{array}$ & $\begin{array}{c}\sigma_{\mathrm{y}}(\mathrm{NS}) \\
(\mathrm{m})\end{array}$ & $\begin{array}{c}\sigma_{\mathrm{z}}(\mathrm{NS}) \\
(\mathrm{m})\end{array}$ & $\begin{array}{c}\text { Dose }(\mathrm{AS}) \\
(\mathrm{rem})\end{array}$ & $\begin{array}{c}\sigma_{\mathrm{y}}(\mathrm{AS}) \\
(\mathrm{m})\end{array}$ & $\begin{array}{c}\sigma_{\mathrm{z}}(\mathrm{AS}) \\
(\mathrm{m})\end{array}$ \\
\hline 1.8 & $0.1238 \mathrm{E}+02$ & $0.8940 \mathrm{E}+02$ & $0.5919 \mathrm{E}+02$ & $0.1238 \mathrm{E}+02$ & $0.8944 \mathrm{E}+02$ & $0.5919 \mathrm{E}+02$ \\
3.6 & $0.5651 \mathrm{E}+01$ & $0.1757 \mathrm{E}+03$ & $0.8843 \mathrm{E}+02$ & $0.5650 \mathrm{E}+01$ & $0.1758 \mathrm{E}+03$ & $0.8843 \mathrm{E}+02$ \\
5.4 & $0.3304 \mathrm{E}+01$ & $0.2621 \mathrm{E}+03$ & $0.1105 \mathrm{E}+03$ & $0.3303 \mathrm{E}+01$ & $0.2622 \mathrm{E}+03$ & $0.1105 \mathrm{E}+03$ \\
7.2 & $0.2219 \mathrm{E}+01$ & $0.3484 \mathrm{E}+03$ & $0.1288 \mathrm{E}+03$ & $0.2218 \mathrm{E}+01$ & $0.3486 \mathrm{E}+03$ & $0.1288 \mathrm{E}+03$ \\
9.0 & $0.1619 \mathrm{E}+01$ & $0.4348 \mathrm{E}+03$ & $0.1449 \mathrm{E}+03$ & $0.1618 \mathrm{E}+01$ & $0.4350 \mathrm{E}+03$ & $0.1449 \mathrm{E}+03$ \\
10. & $0.1247 \mathrm{E}+01$ & $0.5211 \mathrm{E}+03$ & $0.1593 \mathrm{E}+03$ & $0.1247 \mathrm{E}+01$ & $0.5214 \mathrm{E}+03$ & $0.1593 \mathrm{E}+03$ \\
12.6 & $0.9986 \mathrm{E}+00$ & $0.6075 \mathrm{E}+03$ & $0.1725 \mathrm{E}+03$ & $0.9982 \mathrm{E}+00$ & $0.6078 \mathrm{E}+03$ & $0.1725 \mathrm{E}+03$ \\
14.4 & $0.8228 \mathrm{E}+00$ & $0.6938 \mathrm{E}+03$ & $0.1848 \mathrm{E}+03$ & $0.8225 \mathrm{E}+00$ & $0.6942 \mathrm{E}+03$ & $0.1848 \mathrm{E}+03$ \\
16.2 & $0.6932 \mathrm{E}+00$ & $0.7802 \mathrm{E}+03$ & $0.1963 \mathrm{E}+03$ & $0.6929 \mathrm{E}+00$ & $0.7806 \mathrm{E}+03$ & $0.1963 \mathrm{E}+03$ \\
18.0 & $0.5943 \mathrm{E}+00$ & $0.8665 \mathrm{E}+03$ & $0.2071 \mathrm{E}+03$ & $0.5940 \mathrm{E}+00$ & $0.8670 \mathrm{E}+03$ & $0.2071 \mathrm{E}+03$ \\
19.8 & $0.5169 \mathrm{E}+00$ & $0.9529 \mathrm{E}+03$ & $0.2175 \mathrm{E}+03$ & $0.5167 \mathrm{E}+00$ & $0.9534 \mathrm{E}+03$ & $0.2175 \mathrm{E}+03$ \\
21.6 & $0.4550 \mathrm{E}+00$ & $0.1039 \mathrm{E}+04$ & $0.2273 \mathrm{E}+03$ & $0.4547 \mathrm{E}+00$ & $0.1040 \mathrm{E}+04$ & $0.2273 \mathrm{E}+03$ \\
23.4 & $0.4124 \mathrm{E}+00$ & $0.1104 \mathrm{E}+04$ & $0.2367 \mathrm{E}+03$ & $0.4123 \mathrm{E}+00$ & $0.1104 \mathrm{E}+04$ & $0.2367 \mathrm{E}+03$ \\
25.2 & $0.3837 \mathrm{E}+00$ & $0.1145 \mathrm{E}+04$ & $0.2458 \mathrm{E}+03$ & $0.3836 \mathrm{E}+00$ & $0.1146 \mathrm{E}+04$ & $0.2458 \mathrm{E}+03$ \\
27.0 & $0.3588 \mathrm{E}+00$ & $0.1185 \mathrm{E}+04$ & $0.2545 \mathrm{E}+03$ & $0.3586 \mathrm{E}+00$ & $0.1186 \mathrm{E}+04$ & $0.2545 \mathrm{E}+03$ \\
28.8 & $0.3369 \mathrm{E}+00$ & $0.1224 \mathrm{E}+04$ & $0.2630 \mathrm{E}+03$ & $0.3367 \mathrm{E}+00$ & $0.1225 \mathrm{E}+04$ & $0.2630 \mathrm{E}+03$ \\
30.6 & $0.3175 \mathrm{E}+00$ & $0.1262 \mathrm{E}+04$ & $0.2711 \mathrm{E}+03$ & $0.3173 \mathrm{E}+00$ & $0.1262 \mathrm{E}+04$ & $0.2711 \mathrm{E}+03$ \\
\hline
\end{tabular}

Table 36. Same as Table 33, but for case 4

\begin{tabular}{|r|c|c|c|c|c|c|}
\hline $\begin{array}{c}\mathbf{x} \\
(\mathrm{km})\end{array}$ & $\begin{array}{c}\text { Dose (NS) } \\
(\mathrm{rem})\end{array}$ & $\begin{array}{c}\sigma_{\mathrm{y}}(\mathrm{NS}) \\
(\mathrm{m})\end{array}$ & $\begin{array}{c}\sigma_{\mathbf{z}}(\mathrm{NS}) \\
(\mathrm{m})\end{array}$ & $\begin{array}{c}\text { Dose (AS) } \\
(\mathrm{rem})\end{array}$ & $\begin{array}{c}\sigma_{\mathrm{y}}(\mathrm{AS}) \\
(\mathrm{m})\end{array}$ & $\begin{array}{c}\sigma_{\mathrm{z}}(\mathrm{AS}) \\
(\mathrm{m})\end{array}$ \\
\hline 1.8 & $0.8735 \mathrm{E}-05$ & $0.8940 \mathrm{E}+02$ & $0.5919 \mathrm{E}+02$ & $0.8737 \mathrm{E}-05$ & $0.8944 \mathrm{E}+02$ & $0.5919 \mathrm{E}+02$ \\
3.6 & $0.3907 \mathrm{E}-05$ & $0.1757 \mathrm{E}+03$ & $0.8843 \mathrm{E}+02$ & $0.3907 \mathrm{E}-05$ & $0.1758 \mathrm{E}+03$ & $0.8843 \mathrm{E}+02$ \\
5.4 & $0.2239 \mathrm{E}-05$ & $0.2621 \mathrm{E}+03$ & $0.1105 \mathrm{E}+03$ & $0.2238 \mathrm{E}-05$ & $0.2622 \mathrm{E}+03$ & $0.1105 \mathrm{E}+03$ \\
7.2 & $0.1474 \mathrm{E}-05$ & $0.3484 \mathrm{E}+03$ & $0.1288 \mathrm{E}+03$ & $0.1473 \mathrm{E}-05$ & $0.346 \mathrm{E}+03$ & $0.1288 \mathrm{E}+03$ \\
9.0 & $0.1054 \mathrm{E}-05$ & $0.4348 \mathrm{E}+03$ & $0.1449 \mathrm{E}+03$ & $0.1053 \mathrm{E}-05$ & $0.4350 \mathrm{E}+03$ & $0.1449 \mathrm{E}+03$ \\
10.8 & $0.7955 \mathrm{E}-06$ & $0.5211 \mathrm{E}+03$ & $0.1593 \mathrm{E}+03$ & $0.7952 \mathrm{E}-06$ & $0.5214 \mathrm{E}+03$ & $0.1593 \mathrm{E}+03$ \\
12.6 & $0.6242 \mathrm{E}-06$ & $0.6075 \mathrm{E}+03$ & $0.1725 \mathrm{E}+03$ & $0.6240 \mathrm{E}-06$ & $0.6078 \mathrm{E}+03$ & $0.1725 \mathrm{E}+03$ \\
14.4 & $0.5041 \mathrm{E}-06$ & $0.6938 \mathrm{E}+03$ & $0.1848 \mathrm{E}+03$ & $0.5039 \mathrm{E}-06$ & $0.6942 \mathrm{E}+03$ & $0.1848 \mathrm{E}+03$ \\
16.2 & $0.4162 \mathrm{E}-06$ & $0.7802 \mathrm{E}+03$ & $0.1963 \mathrm{E}+03$ & $0.4160 \mathrm{E}-06$ & $0.7806 \mathrm{E}+03$ & $0.1963 \mathrm{E}+03$ \\
18.0 & $0.3497 \mathrm{E}-06$ & $0.8665 \mathrm{E}+03$ & $0.2071 \mathrm{E}+03$ & $0.3495 \mathrm{E}-06$ & $0.8670 \mathrm{E}+03$ & $0.2071 \mathrm{E}+03$ \\
19.8 & $0.2981 \mathrm{E}-06$ & $0.9529 \mathrm{E}+03$ & $0.2175 \mathrm{E}+03$ & $0.2979 \mathrm{E}-06$ & $0.9534 \mathrm{E}+03$ & $0.2175 \mathrm{E}+03$ \\
21.6 & $0.2571 \mathrm{E}-06$ & $0.1039 \mathrm{E}+04$ & $0.2273 \mathrm{E}+03$ & $0.2570 \mathrm{E}-06$ & $0.1040 \mathrm{E}+04$ & $0.2273 \mathrm{E}+03$ \\
23.4 & $0.2284 \mathrm{E}-06$ & $0.1104 \mathrm{E}+04$ & $0.2367 \mathrm{E}+03$ & $0.2283 \mathrm{E}-06$ & $0.1104 \mathrm{E}+04$ & $0.2367 \mathrm{E}+03$ \\
25.2 & $0.2083 \mathrm{E}-06$ & $0.1145 \mathrm{E}+04$ & $0.2458 \mathrm{E}+03$ & $0.2082 \mathrm{E}-06$ & $0.1146 \mathrm{E}+04$ & $0.2458 \mathrm{E}+03$ \\
27.0 & $0.1908 \mathrm{E}-06$ & $0.1185 \mathrm{E}+04$ & $0.2545 \mathrm{E}+03$ & $0.1907 \mathrm{E}-06$ & $0.1186 \mathrm{E}+04$ & $0.2545 \mathrm{E}+03$ \\
28.8 & $0.1756 \mathrm{E}-06$ & $0.1224 \mathrm{E}+04$ & $0.2630 \mathrm{E}+03$ & $0.1755 \mathrm{E}-06$ & $0.1225 \mathrm{E}+04$ & $0.2630 \mathrm{E}+03$ \\
30.6 & $0.1622 \mathrm{E}-06$ & $0.1262 \mathrm{E}+04$ & $0.2711 \mathrm{E}+03$ & $0.1621 \mathrm{E}-06$ & $0.1262 \mathrm{E}+04$ & $0.2711 \mathrm{E}+03$ \\
\hline
\end{tabular}


Table 37. Same as Table 33, but for case 5

\begin{tabular}{|c|c|c|c|c|c|c|}
\hline $\begin{array}{c}\mathrm{x} \\
(\mathrm{km})\end{array}$ & $\begin{array}{c}\text { Dose }(\mathrm{NS}) \\
(\mathrm{rem})\end{array}$ & $\begin{array}{c}\sigma_{\mathrm{y}}(\mathrm{NS}) \\
(\mathrm{m})\end{array}$ & $\begin{array}{c}\sigma_{\mathrm{z}}(\mathrm{NS}) \\
(\mathrm{m})\end{array}$ & $\begin{array}{c}\text { Dose }(\mathrm{AS}) \\
(\mathrm{rem})\end{array}$ & $\begin{array}{c}\sigma_{y}(\mathrm{AS}) \\
(\mathrm{m})\end{array}$ & $\begin{array}{c}\sigma_{z}(\mathrm{AS}) \\
(\mathrm{m})\end{array}$ \\
\hline 1.8 & $0.2561 \mathrm{E}-05$ & $0.8940 \mathrm{E}+02$ & $0.5919 \mathrm{E}+02$ & $0.2561 \mathrm{E}-05$ & $0.8944 \mathrm{E}+02$ & $0.5919 \mathrm{E}+02$ \\
3.6 & $0.1169 \mathrm{E}-05$ & $0.1757 \mathrm{E}+03$ & $0.8843 \mathrm{E}+02$ & $0.1169 \mathrm{E}-05$ & $0.1758 \mathrm{E}+03$ & $0.8843 \mathrm{E}+02$ \\
5.4 & $0.6835 \mathrm{E}-06$ & $0.2621 \mathrm{E}+03$ & $0.1105 \mathrm{E}+03$ & $0.6833 \mathrm{E}-06$ & $0.2622 \mathrm{E}+03$ & $0.1105 \mathrm{E}+03$ \\
7.2 & $0.4590 \mathrm{E}-06$ & $0.3484 \mathrm{E}+03$ & $0.1288 \mathrm{E}+03$ & $0.4588 \mathrm{E}-06$ & $0.3486 \mathrm{E}+03$ & $0.1288 \mathrm{E}+03$ \\
9.0 & $0.3348 \mathrm{E}-06$ & $0.4348 \mathrm{E}+03$ & $0.1449 \mathrm{E}+03$ & $0.3347 \mathrm{E}-06$ & $0.4350 \mathrm{E}+03$ & $0.1449 \mathrm{E}+03$ \\
10.8 & $0.2580 \mathrm{E}-06$ & $0.5211 \mathrm{E}+03$ & $0.1593 \mathrm{E}+03$ & $0.2579 \mathrm{E}-06$ & $0.5214 \mathrm{E}+03$ & $0.1593 \mathrm{E}+03$ \\
12.6 & $0.2066 \mathrm{E}-06$ & $0.6075 \mathrm{E}+03$ & $0.1725 \mathrm{E}+03$ & $0.2065 \mathrm{E}-06$ & $0.6078 \mathrm{E}+03$ & $0.1725 \mathrm{E}+03$ \\
14.4 & $0.1702 \mathrm{E}-06$ & $0.6938 \mathrm{E}+03$ & $0.1848 \mathrm{E}+03$ & $0.1701 \mathrm{E}-06$ & $0.6942 \mathrm{E}+03$ & $0.1848 \mathrm{E}+03$ \\
16.2 & $0.1434 \mathrm{E}-06$ & $0.7802 \mathrm{E}+03$ & $0.1963 \mathrm{E}+03$ & $0.1433 \mathrm{E}-06$ & $0.7806 \mathrm{E}+03$ & $0.1963 \mathrm{E}+03$ \\
18.0 & $0.1229 \mathrm{E}-06$ & $0.8665 \mathrm{E}+03$ & $0.2071 \mathrm{E}+03$ & $0.1229 \mathrm{E}-06$ & $0.8670 \mathrm{E}+03$ & $0.2071 \mathrm{E}+03$ \\
19.8 & $0.1069 \mathrm{E}-06$ & $0.9529 \mathrm{E}+03$ & $0.2175 \mathrm{E}+03$ & $0.1069 \mathrm{E}-06$ & $0.9534 \mathrm{E}+03$ & $0.2175 \mathrm{E}+03$ \\
21.6 & $0.9411 \mathrm{E}-07$ & $0.1039 \mathrm{E}+04$ & $0.2273 \mathrm{E}+03$ & $0.9407 \mathrm{E}-07$ & $0.1040 \mathrm{E}+04$ & $0.2273 \mathrm{E}+03$ \\
23.4 & $0.8532 \mathrm{E}-07$ & $0.1104 \mathrm{E}+04$ & $0.2367 \mathrm{E}+03$ & $0.8528 \mathrm{E}-07$ & $0.1104 \mathrm{E}+04$ & $0.2367 \mathrm{E}+03$ \\
25.2 & $0.7938 \mathrm{E}-07$ & $0.1145 \mathrm{E}+04$ & $0.2458 \mathrm{E}+03$ & $0.7934 \mathrm{E}-07$ & $0.1146 \mathrm{E}+04$ & $0.2458 \mathrm{E}+03$ \\
27.0 & $0.7422 \mathrm{E}-07$ & $0.1185 \mathrm{E}+04$ & $0.2545 \mathrm{E}+03$ & $0.7418 \mathrm{E}-07$ & $0.1186 \mathrm{E}+04$ & $0.2545 \mathrm{E}+03$ \\
28.8 & $0.6969 \mathrm{E}-07$ & $0.1224 \mathrm{E}+04$ & $0.2630 \mathrm{E}+03$ & $0.6965 \mathrm{E}-07$ & $0.1225 \mathrm{E}+04$ & $0.2630 \mathrm{E}+03$ \\
30.6 & $0.6568 \mathrm{E}-07$ & $0.1262 \mathrm{E}+04$ & $0.2711 \mathrm{E}+03$ & $0.6564 \mathrm{E}-07$ & $0.1262 \mathrm{E}+04$ & $0.2711 \mathrm{E}+03$ \\
\hline
\end{tabular}

Table 38. Same as Table 33, but for case 6

\begin{tabular}{|c|c|c|c|c|c|c|}
\hline $\begin{array}{c}\mathrm{x} \\
(\mathrm{km})\end{array}$ & $\begin{array}{c}\text { Dose (NS) } \\
(\mathrm{rem})\end{array}$ & $\begin{array}{c}\sigma_{\mathrm{y}}(\mathrm{NS}) \\
(\mathrm{m})\end{array}$ & $\begin{array}{c}\sigma_{\mathrm{z}}(\mathrm{NS}) \\
(\mathrm{m})\end{array}$ & $\begin{array}{c}\text { Dose (AS) } \\
(\mathrm{rem})\end{array}$ & $\begin{array}{c}\sigma_{\mathrm{y}}(\mathrm{AS}) \\
(\mathrm{m})\end{array}$ & $\begin{array}{c}\sigma_{\mathrm{z}}(\mathrm{AS}) \\
(\mathrm{m})\end{array}$ \\
\hline 1.8 & $0.4997 \mathrm{E}-06$ & $0.2103 \mathrm{E}+03$ & $0.2103 \mathrm{E}+03$ & $0.4992 \mathrm{E}-06$ & $0.2104 \mathrm{E}+03$ & $0.2104 \mathrm{E}+03$ \\
3.6 & $0.1308 \mathrm{E}-06$ & $0.4175 \mathrm{E}+03$ & $0.4175 \mathrm{E}+03$ & $0.1307 \mathrm{E}-06$ & $0.4177 \mathrm{E}+03$ & $0.4178 \mathrm{E}+03$ \\
5.4 & $0.5876 \mathrm{E}-07$ & $0.6248 \mathrm{E}+03$ & $0.6248 \mathrm{E}+03$ & $0.5870 \mathrm{E}-07$ & $0.6251 \mathrm{E}+03$ & $0.6251 \mathrm{E}+03$ \\
7.2 & $0.3452 \mathrm{E}-07$ & $0.8320 \mathrm{E}+03$ & $0.8000 \mathrm{E}+03$ & $0.3451 \mathrm{E}-07$ & $0.8324 \mathrm{E}+03$ & $0.8000 \mathrm{E}+03$ \\
9.0 & $0.2764 \mathrm{E}-07$ & $0.1039 \mathrm{E}+04$ & $0.8000 \mathrm{E}+03$ & $0.2762 \mathrm{E}-07$ & $0.1040 \mathrm{E}+04$ & $0.8000 \mathrm{E}+03$ \\
10.8 & $0.2304 \mathrm{E}-07$ & $0.1246 \mathrm{E}+04$ & $0.8000 \mathrm{E}+03$ & $0.2303 \mathrm{E}-07$ & $0.1247 \mathrm{E}+04$ & $0.8000 \mathrm{E}+03$ \\
12.6 & $0.1976 \mathrm{E}-07$ & $0.1454 \mathrm{E}+04$ & $0.8000 \mathrm{E}+03$ & $0.1975 \mathrm{E}-07$ & $0.1454 \mathrm{E}+04$ & $0.8000 \mathrm{E}+03$ \\
14.4 & $0.1729 \mathrm{E}-07$ & $0.1661 \mathrm{E}+04$ & $0.8000 \mathrm{E}+03$ & $0.1728 \mathrm{E}-07$ & $0.1662 \mathrm{E}+04$ & $0.8000 \mathrm{E}+03$ \\
16.2 & $0.1537 \mathrm{E}-07$ & $0.1868 \mathrm{E}+04$ & $0.8000 \mathrm{E}+03$ & $0.1537 \mathrm{E}-07$ & $0.1869 \mathrm{E}+04$ & $0.8000 \mathrm{E}+03$ \\
18.0 & $0.1384 \mathrm{E}-07$ & $0.2075 \mathrm{E}+04$ & $0.8000 \mathrm{E}+03$ & $0.1383 \mathrm{E}-07$ & $0.2076 \mathrm{E}+04$ & $0.8000 \mathrm{E}+03$ \\
19.8 & $0.1258 \mathrm{E}-07$ & $0.2283 \mathrm{E}+04$ & $0.8000 \mathrm{E}+03$ & $0.1258 \mathrm{E}-07$ & $0.2284 \mathrm{E}+04$ & $0.8000 \mathrm{E}+03$ \\
21.6 & $0.1154 \mathrm{E}-07$ & $0.2490 \mathrm{E}+04$ & $0.8000 \mathrm{E}+03$ & $0.1153 \mathrm{E}-07$ & $0.2491 \mathrm{E}+04$ & $0.8000 \mathrm{E}+03$ \\
23.4 & $0.1086 \mathrm{E}-07$ & $0.2645 \mathrm{E}+04$ & $0.8000 \mathrm{E}+03$ & $0.1085 \mathrm{E}-07$ & $0.2646 \mathrm{E}+04$ & $0.8000 \mathrm{E}+03$ \\
25.2 & $0.1047 \mathrm{E}-07$ & $0.2745 \mathrm{E}+04$ & $0.8000 \mathrm{E}+03$ & $0.1046 \mathrm{E}-07$ & $0.2746 \mathrm{E}+04$ & $0.8000 \mathrm{E}+03$ \\
27.0 & $0.1011 \mathrm{E}-07$ & $0.2841 \mathrm{E}+04$ & $0.8000 \mathrm{E}+03$ & $0.1011 \mathrm{E}-07$ & $0.2842 \mathrm{E}+04$ & $0.8000 \mathrm{E}+03$ \\
28.8 & $0.9790 \mathrm{E}-08$ & $0.2934 \mathrm{E}+04$ & $0.8000 \mathrm{E}+03$ & $0.9785 \mathrm{E}-08$ & $0.2935 \mathrm{E}+04$ & $0.8000 \mathrm{E}+03$ \\
30.6 & $0.9498 \mathrm{E}-08$ & $0.3024 \mathrm{E}+04$ & $0.8000 \mathrm{E}+03$ & $0.9493 \mathrm{E}-08$ & $0.3026 \mathrm{E}+04$ & $0.8000 \mathrm{E}+03$ \\
\hline
\end{tabular}


Table 39. Same as Table 33, but for case 7

\begin{tabular}{|r|c|c|c|c|c|c|}
\hline $\begin{array}{c}\mathrm{x} \\
(\mathrm{km})\end{array}$ & $\begin{array}{c}\text { Dose }(\mathrm{NS}) \\
(\mathrm{rem})\end{array}$ & $\begin{array}{c}\sigma_{\mathrm{y}}(\mathrm{NS}) \\
(\mathrm{m})\end{array}$ & $\begin{array}{c}\sigma_{\mathrm{z}}(\mathrm{NS}) \\
(\mathrm{m})\end{array}$ & $\begin{array}{c}\text { Dose (AS) } \\
(\mathrm{rem})\end{array}$ & $\begin{array}{c}\sigma_{\mathrm{y}}(\mathrm{AS}) \\
(\mathrm{m})\end{array}$ & $\begin{array}{c}\sigma_{\mathrm{z}}(\mathrm{AS}) \\
(\mathrm{m})\end{array}$ \\
\hline 1.8 & $0.4997 \mathrm{E}-06$ & $0.2103 \mathrm{E}+03$ & $0.2103 \mathrm{E}+03$ & $0.4992 \mathrm{E}-06$ & $0.2104 \mathrm{E}+03$ & $0.2104 \mathrm{E}+03$ \\
3.6 & $0.1364 \mathrm{E}-06$ & $0.4175 \mathrm{E}+03$ & $0.4000 \mathrm{E}+03$ & $0.1363 \mathrm{E}-06$ & $0.4177 \mathrm{E}+03$ & $0.4000 \mathrm{E}+03$ \\
5.4 & $0.9115 \mathrm{E}-07$ & $0.6248 \mathrm{E}+03$ & $0.4000 \mathrm{E}+03$ & $0.9111 \mathrm{E}-07$ & $0.6251 \mathrm{E}+03$ & $0.4000 \mathrm{E}+03$ \\
7.2 & $0.6845 \mathrm{E}-07$ & $0.8320 \mathrm{E}+03$ & $0.4000 \mathrm{E}+03$ & $0.6841 \mathrm{E}-07$ & $0.8324 \mathrm{E}+03$ & $0.4000 \mathrm{E}+03$ \\
9.0 & $0.5480 \mathrm{E}-07$ & $0.1039 \mathrm{E}+04$ & $0.4000 \mathrm{E}+03$ & $0.5477 \mathrm{E}-07$ & $0.1040 \mathrm{E}+04$ & $0.4000 \mathrm{E}+03$ \\
10.8 & $0.4569 \mathrm{E}-07$ & $0.1246 \mathrm{E}+04$ & $0.4000 \mathrm{E}+03$ & $0.4566 \mathrm{E}-07$ & $0.1247 \mathrm{E}+04$ & $0.4000 \mathrm{E}+03$ \\
12.6 & $0.3917 \mathrm{E}-07$ & $0.1454 \mathrm{E}+04$ & $0.4000 \mathrm{E}+03$ & $0.3915 \mathrm{E}-07$ & $0.1454 \mathrm{E}+04$ & $0.4000 \mathrm{E}+03$ \\
14.4 & $0.3429 \mathrm{E}-07$ & $0.1661 \mathrm{E}+04$ & $0.4000 \mathrm{E}+03$ & $0.3427 \mathrm{E}-07$ & $0.1662 \mathrm{E}+04$ & $0.4000 \mathrm{E}+03$ \\
16.2 & $0.3048 \mathrm{E}-07$ & $0.1868 \mathrm{E}+04$ & $0.4000 \mathrm{E}+03$ & $0.3047 \mathrm{E}-07$ & $0.1869 \mathrm{E}+04$ & $0.4000 \mathrm{E}+03$ \\
18.0 & $0.2744 \mathrm{E}-07$ & $0.2075 \mathrm{E}+04$ & $0.4000 \mathrm{E}+03$ & $0.2743 \mathrm{E}-07$ & $0.2076 \mathrm{E}+04$ & $0.4000 \mathrm{E}+03$ \\
19.8 & $0.2495 \mathrm{E}-07$ & $0.2283 \mathrm{E}+04$ & $0.4000 \mathrm{E}+03$ & $0.2494 \mathrm{E}-07$ & $0.2284 \mathrm{E}+04$ & $0.4000 \mathrm{E}+03$ \\
21.6 & $0.2287 \mathrm{E}-07$ & $0.2490 \mathrm{E}+04$ & $0.4000 \mathrm{E}+03$ & $0.2286 \mathrm{E}-07$ & $0.2491 \mathrm{E}+04$ & $0.4000 \mathrm{E}+03$ \\
23.4 & $0.2153 \mathrm{E}-07$ & $0.2645 \mathrm{E}+04$ & $0.4000 \mathrm{E}+03$ & $0.2152 \mathrm{E}-07$ & $0.2646 \mathrm{E}+04$ & $0.4000 \mathrm{E}+03$ \\
25.2 & $0.2075 \mathrm{E}-07$ & $0.2745 \mathrm{E}+04$ & $0.4000 \mathrm{E}+03$ & $0.2074 \mathrm{E}-07$ & $0.2746 \mathrm{E}+04$ & $0.4000 \mathrm{E}+03$ \\
27.0 & $0.2005 \mathrm{E}-07$ & $0.2841 \mathrm{E}+04$ & $0.4000 \mathrm{E}+03$ & $0.2004 \mathrm{E}-07$ & $0.2842 \mathrm{E}+04$ & $0.4000 \mathrm{E}+03$ \\
28.8 & $0.1941 \mathrm{E}-07$ & $0.2934 \mathrm{E}+04$ & $0.4000 \mathrm{E}+03$ & $0.1940 \mathrm{E}-07$ & $0.2935 \mathrm{E}+04$ & $0.4000 \mathrm{E}+03$ \\
30.6 & $0.1883 \mathrm{E}-07$ & $0.3024 \mathrm{E}+04$ & $0.4000 \mathrm{E}+03$ & $0.1882 \mathrm{E}-07$ & $0.3026 \mathrm{E}+04$ & $0.4000 \mathrm{E}+03$ \\
\hline
\end{tabular}

Table 40. Same as Table 33, but for case 8

\begin{tabular}{|r|c|c|c|c|c|c|}
\hline $\begin{array}{c}\mathrm{X} \\
(\mathrm{km})\end{array}$ & $\begin{array}{c}\text { Dose (NS) } \\
(\mathrm{rem})\end{array}$ & $\begin{array}{c}\sigma_{\mathrm{y}}(\mathrm{NS}) \\
(\mathrm{m})\end{array}$ & $\begin{array}{c}\sigma_{\mathrm{z}}(\mathrm{NS}) \\
(\mathrm{m})\end{array}$ & $\begin{array}{c}\text { Dose }(\mathrm{AS}) \\
(\mathrm{rem})\end{array}$ & $\begin{array}{c}\sigma_{\mathrm{y}}(\mathrm{AS}) \\
(\mathrm{m})\end{array}$ & $\begin{array}{c}\sigma_{\mathrm{z}}(\mathrm{AS}) \\
(\mathrm{m})\end{array}$ \\
\hline 1.8 & $0.8523 \mathrm{E}-06$ & $0.1585 \mathrm{E}+03$ & $0.1584 \mathrm{E}+03$ & $0.8516 \mathrm{E}-06$ & $0.1586 \mathrm{E}+03$ & $0.1585 \mathrm{E}+03$ \\
3.6 & $0.2296 \mathrm{E}-06$ & $0.3139 \mathrm{E}+03$ & $0.3138 \mathrm{E}+03$ & $0.2293 \mathrm{E}-06$ & $0.3141 \mathrm{E}+03$ & $0.3140 \mathrm{E}+03$ \\
5.4 & $0.1213 \mathrm{E}-06$ & $0.4693 \mathrm{E}+03$ & $0.4000 \mathrm{E}+03$ & $0.1213 \mathrm{E}-06$ & $0.4696 \mathrm{E}+03$ & $0.4000 \mathrm{E}+03$ \\
7.2 & $0.9115 \mathrm{E}-07$ & $0.6248 \mathrm{E}+03$ & $0.4000 \mathrm{E}+03$ & $0.9111 \mathrm{E}-07$ & $0.6251 \mathrm{E}+03$ & $0.4000 \mathrm{E}+03$ \\
9.0 & $0.7299 \mathrm{E}-07$ & $0.7802 \mathrm{E}+03$ & $0.4000 \mathrm{E}+03$ & $0.7296 \mathrm{E}-07$ & $0.7806 \mathrm{E}+03$ & $0.4000 \mathrm{E}+03$ \\
10.8 & $0.6087 \mathrm{E}-07$ & $0.9356 \mathrm{E}+03$ & $0.4000 \mathrm{E}+03$ & $0.6084 \mathrm{E}-07$ & $0.9361 \mathrm{E}+03$ & $0.4000 \mathrm{E}+03$ \\
12.6 & $0.5220 \mathrm{E}-07$ & $0.1091 \mathrm{E}+04$ & $0.4000 \mathrm{E}+03$ & $0.5217 \mathrm{E}-07$ & $0.1092 \mathrm{E}+04$ & $0.4000 \mathrm{E}+03$ \\
14.4 & $0.4569 \mathrm{E}-07$ & $0.1246 \mathrm{E}+04$ & $0.4000 \mathrm{E}+03$ & $0.4566 \mathrm{E}-07$ & $0.1247 \mathrm{E}+04$ & $0.4000 \mathrm{E}+03$ \\
16.2 & $0.4062 \mathrm{E}-07$ & $0.1402 \mathrm{E}+04$ & $0.4000 \mathrm{E}+03$ & $0.4060 \mathrm{E}-07$ & $0.1403 \mathrm{E}+04$ & $0.4000 \mathrm{E}+03$ \\
18.0 & $0.3657 \mathrm{E}-07$ & $0.1557 \mathrm{E}+04$ & $0.4000 \mathrm{E}+03$ & $0.3655 \mathrm{E}-07$ & $0.1558 \mathrm{E}+04$ & $0.4000 \mathrm{E}+03$ \\
19.8 & $0.3325 \mathrm{E}-07$ & $0.1713 \mathrm{E}+04$ & $0.4000 \mathrm{E}+03$ & $0.3323 \mathrm{E}-07$ & $0.1714 \mathrm{E}+04$ & $0.4000 \mathrm{E}+03$ \\
21.6 & $0.3048 \mathrm{E}-07$ & $0.1868 \mathrm{E}+04$ & $0.4000 \mathrm{E}+03$ & $0.3047 \mathrm{E}-07$ & $0.1869 \mathrm{E}+04$ & $0.4000 \mathrm{E}+03$ \\
23.4 & $0.2870 \mathrm{E}-07$ & $0.1984 \mathrm{E}+04$ & $0.4000 \mathrm{E}+03$ & $0.2868 \mathrm{E}-07$ & $0.1985 \mathrm{E}+04$ & $0.4000 \mathrm{E}+03$ \\
25.2 & $0.2766 \mathrm{E}-07$ & $0.2059 \mathrm{E}+04$ & $0.4000 \mathrm{E}+03$ & $0.2764 \mathrm{E}-07$ & $0.2060 \mathrm{E}+04$ & $0.4000 \mathrm{E}+03$ \\
27.0 & $0.2672 \mathrm{E}-07$ & $0.2131 \mathrm{E}+04$ & $0.4000 \mathrm{E}+03$ & $0.2671 \mathrm{E}-07$ & $0.2132 \mathrm{E}+04$ & $0.4000 \mathrm{E}+03$ \\
28.8 & $0.2587 \mathrm{E}-07$ & $0.2201 \mathrm{E}+04$ & $0.4000 \mathrm{E}+03$ & $0.2586 \mathrm{E}-07$ & $0.2202 \mathrm{E}+04$ & $0.4000 \mathrm{E}+03$ \\
30.6 & $0.2510 \mathrm{E}-07$ & $0.2269 \mathrm{E}+04$ & $0.4000 \mathrm{E}+03$ & $0.2509 \mathrm{E}-07$ & $0.2270 \mathrm{E}+04$ & $0.4000 \mathrm{E}+03$ \\
\hline
\end{tabular}


Table 41. Same as Table 33, but for case 9

\begin{tabular}{|c|c|c|c|c|c|c|}
\hline $\begin{array}{c}\mathrm{x} \\
(\mathrm{km})\end{array}$ & $\begin{array}{c}\text { Dose }(\mathrm{NS}) \\
(\mathrm{rem})\end{array}$ & $\begin{array}{c}\sigma_{\mathrm{y}}(\mathrm{NS}) \\
(\mathrm{m})\end{array}$ & $\begin{array}{c}\sigma_{\mathrm{z}}(\mathrm{NS}) \\
(\mathrm{m})\end{array}$ & $\begin{array}{c}\text { Dose }(\mathrm{AS}) \\
(\mathrm{rem})\end{array}$ & $\begin{array}{c}\sigma_{\mathrm{y}}(\mathrm{AS}) \\
(\mathrm{m})\end{array}$ & $\begin{array}{c}\sigma_{\mathrm{z}}(\mathrm{AS}) \\
(\mathrm{m})\end{array}$ \\
\hline 1.8 & $0.1329 \mathrm{E}-05$ & $0.1239 \mathrm{E}+03$ & $0.1240 \mathrm{E}+03$ & $0.1328 \mathrm{E}-05$ & $0.1240 \mathrm{E}+03$ & $0.1240 \mathrm{E}+03$ \\
3.6 & $0.4072 \mathrm{E}-06$ & $0.2448 \mathrm{E}+03$ & $0.2226 \mathrm{E}+03$ & $0.4070 \mathrm{E}-06$ & $0.2450 \mathrm{E}+03$ & $0.2226 \mathrm{E}+03$ \\
5.4 & $0.2041 \mathrm{E}-06$ & $0.3657 \mathrm{E}+03$ & $0.3026 \mathrm{E}+03$ & $0.2040 \mathrm{E}-06$ & $0.3659 \mathrm{E}+03$ & $0.3026 \mathrm{E}+03$ \\
7.2 & $0.1257 \mathrm{E}-06$ & $0.4866 \mathrm{E}+03$ & $0.3718 \mathrm{E}+03$ & $0.1256 \mathrm{E}-06$ & $0.4869 \mathrm{E}+03$ & $0.3718 \mathrm{E}+03$ \\
9.0 & $0.9374 \mathrm{E}-07$ & $0.6075 \mathrm{E}+03$ & $0.4000 \mathrm{E}+03$ & $0.9370 \mathrm{E}-07$ & $0.6078 \mathrm{E}+03$ & $0.4000 \mathrm{E}+03$ \\
10.8 & $0.7818 \mathrm{E}-07$ & $0.7284 \mathrm{E}+03$ & $0.4000 \mathrm{E}+03$ & $0.7815 \mathrm{E}-07$ & $0.7288 \mathrm{E}+03$ & $0.4000 \mathrm{E}+03$ \\
12.6 & $0.6705 \mathrm{E}-07$ & $0.8493 \mathrm{E}+03$ & $0.4000 \mathrm{E}+03$ & $0.6702 \mathrm{E}-07$ & $0.8497 \mathrm{E}+03$ & $0.4000 \mathrm{E}+03$ \\
14.4 & $0.5870 \mathrm{E}-07$ & $0.9702 \mathrm{E}+03$ & $0.4000 \mathrm{E}+03$ & $0.5867 \mathrm{E}-07$ & $0.9707 \mathrm{E}+03$ & $0.4000 \mathrm{E}+03$ \\
16.2 & $0.5220 \mathrm{E}-07$ & $0.1091 \mathrm{E}+04$ & $0.4000 \mathrm{E}+03$ & $0.5217 \mathrm{E}-07$ & $0.1092 \mathrm{E}+04$ & $0.4000 \mathrm{E}+03$ \\
18.0 & $0.4699 \mathrm{E}-07$ & $0.1212 \mathrm{E}+04$ & $0.4000 \mathrm{E}+03$ & $0.4697 \mathrm{E}-07$ & $0.1213 \mathrm{E}+04$ & $0.4000 \mathrm{E}+03$ \\
19.8 & $0.4273 \mathrm{E}-07$ & $0.1333 \mathrm{E}+04$ & $0.4000 \mathrm{E}+03$ & $0.4271 \mathrm{E}-07$ & $0.1334 \mathrm{E}+04$ & $0.4000 \mathrm{E}+03$ \\
21.6 & $0.3917 \mathrm{E}-07$ & $0.1454 \mathrm{E}+04$ & $0.4000 \mathrm{E}+03$ & $0.3915 \mathrm{E}-07$ & $0.1454 \mathrm{E}+04$ & $0.4000 \mathrm{E}+03$ \\
23.4 & $0.3688 \mathrm{E}-07$ & $0.1544 \mathrm{E}+04$ & $0.4000 \mathrm{E}+03$ & $0.3686 \mathrm{E}-07$ & $0.1545 \mathrm{E}+04$ & $0.4000 \mathrm{E}+03$ \\
25.2 & $0.3554 \mathrm{E}-07$ & $0.1602 \mathrm{E}+04$ & $0.4000 \mathrm{E}+03$ & $0.3552 \mathrm{E}-07$ & $0.1603 \mathrm{E}+04$ & $0.4000 \mathrm{E}+03$ \\
27.0 & $0.3434 \mathrm{E}-07$ & $0.1658 \mathrm{E}+04$ & $0.4000 \mathrm{E}+03$ & $0.3432 \mathrm{E}-07$ & $0.1659 \mathrm{E}+04$ & $0.4000 \mathrm{E}+03$ \\
28.8 & $0.3325 \mathrm{E}-07$ & $0.1713 \mathrm{E}+04$ & $0.4000 \mathrm{E}+03$ & $0.3323 \mathrm{E}-07$ & $0.1714 \mathrm{E}+04$ & $0.4000 \mathrm{E}+03$ \\
30.6 & $0.3226 \mathrm{E}-07$ & $0.1765 \mathrm{E}+04$ & $0.4000 \mathrm{E}+03$ & $0.3224 \mathrm{E}-07$ & $0.1766 \mathrm{E}+04$ & $0.4000 \mathrm{E}+03$ \\
\hline
\end{tabular}

Table 42. Same as Table 33, but for case 10

\begin{tabular}{|r|c|c|c|c|c|c|}
\hline $\begin{array}{c}\mathrm{x} \\
(\mathrm{km})\end{array}$ & $\begin{array}{c}\text { Dose }(\mathrm{NS}) \\
(\mathrm{rem})\end{array}$ & $\begin{array}{c}\sigma_{\mathrm{y}}(\mathrm{NS}) \\
(\mathrm{m})\end{array}$ & $\begin{array}{c}\sigma_{\mathrm{z}}(\mathrm{NS}) \\
(\mathrm{m})\end{array}$ & $\begin{array}{c}\text { Dose }(\mathrm{AS}) \\
(\mathrm{rem})\end{array}$ & $\begin{array}{c}\sigma_{\mathrm{y}}(\mathrm{AS}) \\
(\mathrm{m})\end{array}$ & $\begin{array}{c}\sigma_{\mathrm{z}}(\mathrm{AS}) \\
(\mathrm{m})\end{array}$ \\
\hline 1.8 & $0.3062 \mathrm{E}-05$ & $0.5486 \mathrm{E}+02$ & $0.3811 \mathrm{E}+02$ & $0.3066 \mathrm{E}-05$ & $0.5488 \mathrm{E}+02$ & $0.3811 \mathrm{E}+02$ \\
3.6 & $0.2123 \mathrm{E}-05$ & $0.1067 \mathrm{E}+03$ & $0.5497 \mathrm{E}+02$ & $0.2124 \mathrm{E}-05$ & $0.1067 \mathrm{E}+03$ & $0.5497 \mathrm{E}+02$ \\
5.4 & $0.1441 \mathrm{E}-05$ & $0.1585 \mathrm{E}+03$ & $0.6488 \mathrm{E}+02$ & $0.1441 \mathrm{E}-05$ & $0.1586 \mathrm{E}+03$ & $0.6488 \mathrm{E}+02$ \\
7.2 & $0.1066 \mathrm{E}-05$ & $0.2103 \mathrm{E}+03$ & $0.7140 \mathrm{E}+02$ & $0.1066 \mathrm{E}-05$ & $0.2104 \mathrm{E}+03$ & $0.7140 \mathrm{E}+02$ \\
9.0 & $0.3383 \mathrm{E}-06$ & $0.2621 \mathrm{E}+03$ & $0.7602 \mathrm{E}+02$ & $0.8382 \mathrm{E}-06$ & $0.2622 \mathrm{E}+03$ & $0.7602 \mathrm{E}+02$ \\
10.8 & $0.6881 \mathrm{E}-06$ & $0.3139 \mathrm{E}+03$ & $0.7946 \mathrm{E}+02$ & $0.6880 \mathrm{E}-06$ & $0.3141 \mathrm{E}+03$ & $0.7946 \mathrm{E}+02$ \\
12.6 & $0.5823 \mathrm{E}-06$ & $0.3657 \mathrm{E}+03$ & $0.8213 \mathrm{E}+02$ & $0.5822 \mathrm{E}-06$ & $0.3659 \mathrm{E}+03$ & $0.8213 \mathrm{E}+02$ \\
14.4 & $0.5041 \mathrm{E}-06$ & $0.4175 \mathrm{E}+03$ & $0.8425 \mathrm{E}+02$ & $0.5040 \mathrm{E}-06$ & $0.4177 \mathrm{E}+03$ & $0.8425 \mathrm{E}+02$ \\
16.2 & $0.4440 \mathrm{E}-06$ & $0.4693 \mathrm{E}+03$ & $0.8598 \mathrm{E}+02$ & $0.4439 \mathrm{E}-06$ & $0.4696 \mathrm{E}+03$ & $0.8598 \mathrm{E}+02$ \\
18.0 & $0.3965 \mathrm{E}-06$ & $0.5211 \mathrm{E}+03$ & $0.8742 \mathrm{E}+02$ & $0.3965 \mathrm{E}-06$ & $0.5214 \mathrm{E}+03$ & $0.8742 \mathrm{E}+02$ \\
19.8 & $0.3581 \mathrm{E}-06$ & $0.5730 \mathrm{E}+03$ & $0.8864 \mathrm{E}+02$ & $0.3580 \mathrm{E}-06$ & $0.5732 \mathrm{E}+03$ & $0.8864 \mathrm{E}+02$ \\
21.6 & $0.3264 \mathrm{E}-06$ & $0.6248 \mathrm{E}+03$ & $0.8968 \mathrm{E}+02$ & $0.3263 \mathrm{E}-06$ & $0.6251 \mathrm{E}+03$ & $0.8968 \mathrm{E}+02$ \\
23.4 & $0.3057 \mathrm{E}-06$ & $0.6635 \mathrm{E}+03$ & $0.9058 \mathrm{E}+02$ & $0.3056 \mathrm{E}-06$ & $0.6638 \mathrm{E}+03$ & $0.9058 \mathrm{E}+02$ \\
25.2 & $0.2932 \mathrm{E}-06$ & $0.6884 \mathrm{E}+03$ & $0.9137 \mathrm{E}+02$ & $0.2931 \mathrm{E}-06$ & $0.6888 \mathrm{E}+03$ & $0.9137 \mathrm{E}+02$ \\
27.0 & $0.2821 \mathrm{E}-06$ & $0.7125 \mathrm{E}+03$ & $0.9206 \mathrm{E}+02$ & $0.2820 \mathrm{E}-06$ & $0.7128 \mathrm{E}+03$ & $0.9206 \mathrm{E}+02$ \\
28.8 & $0.2722 \mathrm{E}-06$ & $0.7358 \mathrm{E}+03$ & $0.9267 \mathrm{E}+02$ & $0.2721 \mathrm{E}-06$ & $0.7361 \mathrm{E}+03$ & $0.9267 \mathrm{E}+02$ \\
30.6 & $0.2632 \mathrm{E}-06$ & $0.7583 \mathrm{E}+03$ & $0.9322 \mathrm{E}+02$ & $0.2631 \mathrm{E}-06$ & $0.7587 \mathrm{E}+03$ & $0.9322 \mathrm{E}+02$ \\
\hline
\end{tabular}


Table 43. Same as Table 33, but for case 11

\begin{tabular}{|c|c|c|c|c|c|c|}
\hline $\begin{array}{c}\mathrm{x} \\
(\mathrm{km})\end{array}$ & $\begin{array}{c}\text { Dose (NS) } \\
(\mathrm{rem})\end{array}$ & $\begin{array}{c}\sigma_{\mathrm{y}}(\mathrm{NS}) \\
(\mathrm{m})\end{array}$ & $\begin{array}{c}\sigma_{\mathrm{z}}(\mathrm{NS}) \\
(\mathrm{m})\end{array}$ & $\begin{array}{c}\text { Dose (AS) } \\
(\mathrm{rem})\end{array}$ & $\begin{array}{c}\sigma_{\mathrm{y}}(\mathrm{AS}) \\
(\mathrm{m})\end{array}$ & $\begin{array}{c}\sigma_{\mathrm{z}}(\mathrm{AS}) \\
(\mathrm{m})\end{array}$ \\
\hline 1.8 & $0.6202 \mathrm{E}-06$ & $0.2032 \mathrm{E}+02$ & $0.2034 \mathrm{E}+02$ & $0.6257 \mathrm{E}-06$ & $0.2033 \mathrm{E}+02$ & $0.2034 \mathrm{E}+02$ \\
3.6 & $0.2785 \mathrm{E}-05$ & $0.3759 \mathrm{E}+02$ & $0.3074 \mathrm{E}+02$ & $0.2791 \mathrm{E}-05$ & $0.3761 \mathrm{E}+02$ & $0.3074 \mathrm{E}+02$ \\
5.4 & $0.2781 \mathrm{E}-05$ & $0.5486 \mathrm{E}+02$ & $0.3603 \mathrm{E}+02$ & $0.2785 \mathrm{E}-05$ & $0.5488 \mathrm{E}+02$ & $0.3603 \mathrm{E}+02$ \\
7.2 & $0.2455 \mathrm{E}-05$ & $0.7213 \mathrm{E}+02$ & $0.3950 \mathrm{E}+02$ & $0.2458 \mathrm{E}-05$ & $0.7216 \mathrm{E}+02$ & $0.3950 \mathrm{E}+02$ \\
9.0 & $0.2136 \mathrm{E}-05$ & $0.8940 \mathrm{E}+02$ & $0.4197 \mathrm{E}+02$ & $0.2138 \mathrm{E}-05$ & $0.8944 \mathrm{E}+02$ & $0.4197 \mathrm{E}+02$ \\
10.8 & $0.1870 \mathrm{E}-05$ & $0.1067 \mathrm{E}+03$ & $0.4380 \mathrm{E}+02$ & $0.1872 \mathrm{E}-05$ & $0.1067 \mathrm{E}+03$ & $0.4380 \mathrm{E}+02$ \\
12.6 & $0.1656 \mathrm{E}-05$ & $0.1239 \mathrm{E}+03$ & $0.4522 \mathrm{E}+02$ & $0.1657 \mathrm{E}-05$ & $0.1240 \mathrm{E}+03$ & $0.4522 \mathrm{E}+02$ \\
14.4 & $0.1481 \mathrm{E}-05$ & $0.1412 \mathrm{E}+03$ & $0.4636 \mathrm{E}+02$ & $0.1482 \mathrm{E}-05$ & $0.1413 \mathrm{E}+03$ & $0.4636 \mathrm{E}+02$ \\
16.2 & $0.1338 \mathrm{E}-05$ & $0.1585 \mathrm{E}+03$ & $0.4728 \mathrm{E}+02$ & $0.1339 \mathrm{E}-05$ & $0.1586 \mathrm{E}+03$ & $0.4728 \mathrm{E}+02$ \\
18.0 & $0.1219 \mathrm{E}-05$ & $0.1757 \mathrm{E}+03$ & $0.4805 \mathrm{E}+02$ & $0.1220 \mathrm{E}-05$ & $0.1758 \mathrm{E}+03$ & $0.4805 \mathrm{E}+02$ \\
19.8 & $0.1119 \mathrm{E}-05$ & $0.1930 \mathrm{E}+03$ & $0.4870 \mathrm{E}+02$ & $0.1119 \mathrm{E}-05$ & $0.1931 \mathrm{E}+03$ & $0.4870 \mathrm{E}+02$ \\
21.6 & $0.1033 \mathrm{E}-05$ & $0.2103 \mathrm{E}+03$ & $0.4925 \mathrm{E}+02$ & $0.1034 \mathrm{E}-05$ & $0.2104 \mathrm{E}+03$ & $0.4925 \mathrm{E}+02$ \\
23.4 & $0.9785 \mathrm{E}-06$ & $0.2232 \mathrm{E}+03$ & $0.4973 \mathrm{E}+02$ & $0.9790 \mathrm{E}-06$ & $0.2233 \mathrm{E}+03$ & $0.4973 \mathrm{E}+02$ \\
25.2 & $0.9473 \mathrm{E}-06$ & $0.2315 \mathrm{E}+03$ & $0.5015 \mathrm{E}+02$ & $0.9477 \mathrm{E}-06$ & $0.2316 \mathrm{E}+03$ & $0.5015 \mathrm{E}+02$ \\
27.0 & $0.9187 \mathrm{E}-06$ & $0.2395 \mathrm{E}+03$ & $0.5052 \mathrm{E}+02$ & $0.9191 \mathrm{E}-06$ & $0.2396 \mathrm{E}+03$ & $0.5052 \mathrm{E}+02$ \\
28.8 & $0.8925 \mathrm{E}-06$ & $0.2473 \mathrm{E}+03$ & $0.5085 \mathrm{E}+02$ & $0.8929 \mathrm{E}-06$ & $0.2474 \mathrm{E}+03$ & $0.5085 \mathrm{E}+02$ \\
30.6 & $0.8683 \mathrm{E}-06$ & $0.2548 \mathrm{E}+03$ & $0.5114 \mathrm{E}+02$ & $0.8687 \mathrm{E}-06$ & $0.2549 \mathrm{E}+03$ & $0.5114 \mathrm{E}+02$ \\
\hline
\end{tabular}

Table 44. Same as Table 33, but for case $\mathbf{1 2}$

\begin{tabular}{|c|c|c|c|c|c|c|}
\hline $\begin{array}{c}\mathrm{X} \\
(\mathrm{km})\end{array}$ & $\begin{array}{c}\text { Dose (NS) } \\
\text { (rem) }\end{array}$ & $\begin{array}{c}\sigma_{y}(\mathrm{NS}) \\
(\mathrm{m})\end{array}$ & $\begin{array}{c}\sigma_{\mathrm{z}}(\mathrm{NS}) \\
(\mathrm{m})\end{array}$ & $\begin{array}{c}\text { Dose (AS) } \\
\text { (rem) }\end{array}$ & $\begin{array}{c}\sigma_{y}(\mathrm{AS}) \\
(\mathrm{m})\end{array}$ & $\begin{array}{c}\sigma_{z}(\mathrm{AS}) \\
(\mathrm{m})\end{array}$ \\
\hline 0.6 & $0.2089 \mathrm{E}-04$ & $0.3183 \mathrm{E}+02$ & $0.2917 \mathrm{E}+02$ & $0.2094 E-04$ & $0.3185 \mathrm{E}+02$ & $0.2917 \mathrm{E}+02$ \\
\hline 1.2 & $0.2576 \mathrm{E}-04$ & $0.6061 E+02$ & $0.4608 E+02$ & $0.2578 \mathrm{E}-04$ & $0.6064 E+02$ & $0.4608 E+02$ \\
\hline 1.8 & $0.1921 \mathrm{E}-04$ & $0.8940 E+02$ & $0.5919 E+02$ & $0.1921 \mathrm{E}-04$ & $0.8944 E+02$ & $0.5919 E+02$ \\
\hline 2.4 & $0.1428 \mathrm{E}-04$ & $0.1182 E+03$ & $0.7019 E+02$ & $0.1428 E-04$ & $0.1182 E+03$ & $0.7019 E+02$ \\
\hline 3.0 & $0.1100 \mathrm{E}-04$ & $0.1470 E+03$ & $0.7980 E+02$ & $0.1100 \mathrm{E}-04$ & $0.1470 E+03$ & $0.7980 E+02$ \\
\hline 3.6 & $0.8767 \mathrm{E}-05$ & $0.1757 E+03$ & $0.8843 E+02$ & $0.8765 \mathrm{E}-05$ & $0.1758 E+03$ & $0.8843 E+02$ \\
\hline 4.2 & $0.7179 \mathrm{E}-05$ & $0.2045 E+03$ & $0.9632 E+02$ & $0.7178 E-05$ & $0.2046 E+03$ & $0.9632 E+02$ \\
\hline 4.8 & $0.6012 \mathrm{E}-05$ & $0.2333 E+03$ & $0.1036 E+03$ & $0.6010 \mathrm{E}-05$ & $0.2334 E+03$ & $0.1036 E+03$ \\
\hline 5.4 & $0.5126 \mathrm{E}-05$ & $0.2621 E+03$ & $0.1105 E+03$ & $0.5124 \mathrm{E}-05$ & $0.2622 E+03$ & $0.1105 E+03$ \\
\hline 6.0 & $0.4436 \mathrm{E}-05$ & $0.2909 E+03$ & $0.1169 E+03$ & $0.4435 E-05$ & $0.2910 E+03$ & $0.1169 E+03$ \\
\hline 6.6 & $0.3887 \mathrm{E}-05$ & $0.3197 E+03$ & $0.1230 E+03$ & $0.3886 \mathrm{E}-05$ & $0.3198 E+03$ & $0.1230 E+03$ \\
\hline .2 & $0.3442 \mathrm{E}-05$ & $0.3484 E+03$ & $0.1288 E+03$ & $0.3441 \mathrm{E}-05$ & $0.3486 E+03$ & $0.1288 E+03$ \\
\hline .8 & $0.3076 \mathrm{E}-05$ & $0.3772 E+03$ & $0.1344 E+03$ & $0.3075 \mathrm{E}-05$ & $0.3774 E+03$ & $4 E+03$ \\
\hline .4 & 0.2770 E-05 & $0 E+03$ & $7 E+03$ & 59E-05 & $0.4062 E+03$ & $397 E+03$ \\
\hline .0 & 11E-05 & $0.4348 E+03$ & $449 E+03$ & $10 \mathrm{E}-05$ & $0.4350 E+03$ & $0.1449 E+03$ \\
\hline 9.6 & $0.2291 \mathrm{E}-05$ & $0.4636 E+03$ & $98 E+03$ & $90 \mathrm{E}-05$ & $0.4638 \mathrm{E}+03$ & $0.1498 E+03$ \\
\hline 10.2 & $0.2100 \mathrm{E}-05$ & $24 E+03$ & $346 E+03$ & 99E-05 & $0.4926 \mathrm{E}+03$ & $0.1546 \mathrm{E}+03$ \\
\hline 10.8 & 35E-05 & $11 E+03$ & $93 E+03$ & $34 \mathrm{E}-05$ & $0.5214 \mathrm{E}+03$ & $593 E+03$ \\
\hline 11.4 & 0.1 & $9 E+03$ & $38 E+03$ & $89 \mathrm{E}-05$ & $0.5502 E+03$ & $638 E+03$ \\
\hline 12.0 & $62 \mathrm{E}-05$ & $17 \mathrm{E}+03$ & $82 E+03$ & $62 \mathrm{E}-05$ & $0.5790 E+03$ & $0.1682 E+03$ \\
\hline 12.6 & 49E-05 & $75 E+03$ & $725 E+03$ & 49E-05 & $0.6078 E+03$ & $0.1725 \mathrm{E}+03$ \\
\hline 13.2 & $0.1448 \mathrm{E}-05$ & $0.6363 E+03$ & $0.1767 E+03$ & $0.1448 \mathrm{E}-05$ & $0.6366 \mathrm{E}+03$ & $0.1767 E+03$ \\
\hline
\end{tabular}


Table 44. (cont'd)

\begin{tabular}{|c|c|c|c|c|c|c|}
\hline $\begin{array}{c}\mathrm{x} \\
(\mathrm{km})\end{array}$ & $\begin{array}{l}\text { Dose (NS) } \\
\text { (rem) }\end{array}$ & $\begin{array}{c}\sigma_{y}(\mathrm{NS}) \\
(\mathrm{m})\end{array}$ & $\begin{array}{c}\sigma_{\mathrm{z}}(\mathrm{NS}) \\
(\mathrm{m})\end{array}$ & $\begin{array}{c}\text { Dose (AS) } \\
\text { (rem) }\end{array}$ & $\begin{array}{c}\sigma_{y}(\mathrm{AS}) \\
(\mathrm{m})\end{array}$ & $\begin{array}{c}\sigma_{\mathrm{z}}(\mathrm{AS}) \\
(\mathrm{m})\end{array}$ \\
\hline 13.8 & $0.1358 \mathrm{E}-05$ & $0.6651 \mathrm{E}+03$ & $0.1808 \mathrm{E}+03$ & $0.1357 \mathrm{E}-5$ & $0.6654 \mathrm{E}+03$ & $0.1808 \mathrm{E}+03$ \\
\hline 14.4 & 1277E-05 & $0.6938 E+03$ & $0.1848 E+03$ & $0.1276 E-6 j$ & $0.6942 E+03$ & $0.1848 E+03$ \\
\hline 15.0 & $03 E-05$ & $0.7226 E+03$ & $0.1887 E+03$ & $0.1202 \mathrm{E}-05$ & $0.7230 E+03$ & \\
\hline & $36 \mathrm{E}-05$ & & & $36 \mathrm{E}-05$ & & \\
\hline & & & & & & \\
\hline 16. & & & & & & \\
\hline & E-06 & & & & & \\
\hline 18. & $0 E-06$ & & $0.2071 \mathrm{E}+$ & $16 \mathrm{E}-06$ & & \\
\hline 18. & $88 \mathrm{E}-06$ & 0.89 & $0.2106 \mathrm{E}+03$ & 184E-06 & & \\
\hline 19. & 0.8 & 0.9 & & & & \\
\hline & & & & & & \\
\hline & & & & & & \\
\hline 21 & & & & & & \\
\hline & & & & & & \\
\hline & 0.6 & & & & & \\
\hline & $E-06$ & & & & & \\
\hline & & & & & & \\
\hline & & & & & & \\
\hline & & & & & & \\
\hline & & & & & & \\
\hline & & & & & & \\
\hline & & & & & & \\
\hline & $6 \mathrm{E}-06$ & 0.1 & & E-06 & & \\
\hline & & & & & & \\
\hline & & & & & & \\
\hline & & & & & & \\
\hline & & & & & & \\
\hline & & & & & & \\
\hline
\end{tabular}


Table 45. Same as Table 33 , but for case $\mathbf{1 3}$

\begin{tabular}{|r|c|c|c|c|c|c|}
\hline $\begin{array}{c}\mathrm{x} \\
(\mathrm{km})\end{array}$ & $\begin{array}{c}\text { Dose (NS) } \\
(\mathrm{rem})\end{array}$ & $\begin{array}{c}\sigma_{\mathrm{y}}(\mathrm{NS}) \\
(\mathrm{m})\end{array}$ & $\begin{array}{c}\sigma_{\mathrm{z}}(\mathrm{NS}) \\
(\mathrm{m})\end{array}$ & $\begin{array}{c}\text { Dose }(\mathrm{AS}) \\
(\mathrm{rem})\end{array}$ & $\begin{array}{c}\sigma_{\mathrm{y}}(\mathrm{AS}) \\
(\mathrm{m})\end{array}$ & $\begin{array}{c}\sigma_{\mathrm{z}}(\mathrm{AS}) \\
(\mathrm{m})\end{array}$ \\
\hline 1.8 & $0.6402 \mathrm{E}-05$ & $0.8940 \mathrm{E}+02$ & $0.5919 \mathrm{E}+02$ & $0.6403 \mathrm{E}-05$ & $0.8944 \mathrm{E}+02$ & $0.5919 \mathrm{E}+02$ \\
3.6 & $0.2922 \mathrm{E}-05$ & $0.1757 \mathrm{E}+03$ & $0.8843 \mathrm{E}+02$ & $0.2922 \mathrm{E}-05$ & $0.1758 \mathrm{E}+03$ & $0.8843 \mathrm{E}+02$ \\
5.4 & $0.1709 \mathrm{E}-05$ & $0.2621 \mathrm{E}+03$ & $0.1105 \mathrm{E}+03$ & $0.1708 \mathrm{E}-05$ & $0.2622 \mathrm{E}+03$ & $0.1105 \mathrm{E}+03$ \\
7.2 & $0.1147 \mathrm{E}-05$ & $0.3484 \mathrm{E}+03$ & $0.1288 \mathrm{E}+03$ & $0.1147 \mathrm{E}-05$ & $0.3486 \mathrm{E}+03$ & $0.1288 \mathrm{E}+03$ \\
9.0 & $0.8371 \mathrm{E}-06$ & $0.4348 \mathrm{E}+03$ & $0.1449 \mathrm{E}+03$ & $0.8368 \mathrm{E}-06$ & $0.4350 \mathrm{E}+03$ & $0.1449 \mathrm{E}+03$ \\
10.8 & $0.6449 \mathrm{E}-06$ & $0.5211 \mathrm{E}+03$ & $0.1593 \mathrm{E}+03$ & $0.6447 \mathrm{E}-06$ & $0.5214 \mathrm{E}+03$ & $0.1593 \mathrm{E}+03$ \\
12.6 & $0.5164 \mathrm{E}-06$ & $0.6075 \mathrm{E}+03$ & $0.1725 \mathrm{E}+03$ & $0.5162 \mathrm{E}-06$ & $0.6078 \mathrm{E}+03$ & $0.1725 \mathrm{E}+03$ \\
14.4 & $0.4255 \mathrm{E}-06$ & $0.6938 \mathrm{E}+03$ & $0.1848 \mathrm{E}+03$ & $0.4253 \mathrm{E}-06$ & $0.6942 \mathrm{E}+03$ & $0.1848 \mathrm{E}+03$ \\
16.2 & $0.3585 \mathrm{E}-06$ & $0.7802 \mathrm{E}+03$ & $0.1963 \mathrm{E}+03$ & $0.3583 \mathrm{E}-06$ & $0.7806 \mathrm{E}+03$ & $0.1963 \mathrm{E}+03$ \\
18.0 & $0.3073 \mathrm{E}-06$ & $0.8665 \mathrm{E}+03$ & $0.2071 \mathrm{E}+03$ & $0.3072 \mathrm{E}-06$ & $0.8670 \mathrm{E}+03$ & $0.2071 \mathrm{E}+03$ \\
19.8 & $0.2673 \mathrm{E}-06$ & $0.9529 \mathrm{E}+03$ & $0.2175 \mathrm{E}+03$ & $0.2672 \mathrm{E}-06$ & $0.9534 \mathrm{E}+03$ & $0.2175 \mathrm{E}+03$ \\
21.6 & $0.2353 \mathrm{E}-06$ & $0.1039 \mathrm{E}+04$ & $0.2273 \mathrm{E}+03$ & $0.2352 \mathrm{E}-06$ & $0.1040 \mathrm{E}+04$ & $0.2273 \mathrm{E}+03$ \\
23.4 & $0.2133 \mathrm{E}-06$ & $0.1104 \mathrm{E}+04$ & $0.2367 \mathrm{E}+03$ & $0.2132 \mathrm{E}-06$ & $0.1104 \mathrm{E}+04$ & $0.2367 \mathrm{E}+03$ \\
25.2 & $0.1985 \mathrm{E}-06$ & $0.1145 \mathrm{E}+04$ & $0.2458 \mathrm{E}+03$ & $0.1984 \mathrm{E}-06$ & $0.1146 \mathrm{E}+04$ & $0.2458 \mathrm{E}+03$ \\
27.0 & $0.1855 \mathrm{E}-06$ & $0.1185 \mathrm{E}+04$ & $0.2545 \mathrm{E}+03$ & $0.1855 \mathrm{E}-06$ & $0.1186 \mathrm{E}+04$ & $0.2545 \mathrm{E}+03$ \\
28.8 & $0.1742 \mathrm{E}-06$ & $0.1224 \mathrm{E}+04$ & $0.2630 \mathrm{E}+03$ & $0.1741 \mathrm{E}-06$ & $0.1225 \mathrm{E}+04$ & $0.2630 \mathrm{E}+03$ \\
30.6 & $0.1642 \mathrm{E}-06$ & $0.1262 \mathrm{E}+04$ & $0.2711 \mathrm{E}+03$ & $0.1641 \mathrm{E}-06$ & $0.1262 \mathrm{E}+04$ & $0.2711 \mathrm{E}+03$ \\
\hline
\end{tabular}

Table 46. Same as Table 33 , but for case 14

\begin{tabular}{|r|c|c|c|c|c|c|}
\hline $\begin{array}{c}\mathrm{X} \\
(\mathrm{km})\end{array}$ & $\begin{array}{c}\text { Dose (NS) } \\
(\mathrm{rem})\end{array}$ & $\begin{array}{c}\sigma_{\mathrm{y}}(\mathrm{NS}) \\
(\mathrm{m})\end{array}$ & $\begin{array}{c}\sigma_{\mathrm{z}}(\mathrm{NS}) \\
(\mathrm{m})\end{array}$ & $\begin{array}{c}\text { Dose (AS) } \\
(\mathrm{rem})\end{array}$ & $\begin{array}{c}\sigma_{\mathrm{y}}(\mathrm{AS}) \\
(\mathrm{m})\end{array}$ & $\begin{array}{c}\sigma_{\mathrm{z}}(\mathrm{AS}) \\
(\mathrm{m})\end{array}$ \\
\hline 1.5 & $0.4483 \mathrm{E}-05$ & $0.7501 \mathrm{E}+02$ & $0.5297 \mathrm{E}+02$ & $0.4485 \mathrm{E}-05$ & $0.7504 \mathrm{E}+02$ & $0.5297 \mathrm{E}+02$ \\
3.0 & $0.2201 \mathrm{E}-05$ & $0.1470 \mathrm{E}+03$ & $0.7980 \mathrm{E}+02$ & $0.2201 \mathrm{E}-05$ & $0.1470 \mathrm{E}+03$ & $0.7980 \mathrm{E}+02$ \\
4.5 & $0.1311 \mathrm{E}-05$ & $0.2189 \mathrm{E}+03$ & $0.1000 \mathrm{E}+03$ & $0.1310 \mathrm{E}-05$ & $0.2190 \mathrm{E}+03$ & $0.1000 \mathrm{E}+03$ \\
6.0 & $0.8873 \mathrm{E}-06$ & $0.2909 \mathrm{E}+03$ & $0.1169 \mathrm{E}+03$ & $0.8870 \mathrm{E}-06$ & $0.2910 \mathrm{E}+03$ & $0.1169 \mathrm{E}+03$ \\
7.5 & $0.6501 \mathrm{E}-06$ & $0.3628 \mathrm{E}+03$ & $0.1316 \mathrm{E}+03$ & $0.6499 \mathrm{E}-06$ & $0.3630 \mathrm{E}+03$ & $0.1316 \mathrm{E}+03$ \\
9 & $0.5023 \mathrm{E}-06$ & $0.4348 \mathrm{E}+03$ & $0.1449 \mathrm{E}+03$ & $0.5021 \mathrm{E}-06$ & $0.4350 \mathrm{E}+03$ & $0.1449 \mathrm{E}+03$ \\
10.5 & $0.4029 \mathrm{E}-06$ & $0.5068 \mathrm{E}+03$ & $0.1570 \mathrm{E}+03$ & $0.4028 \mathrm{E}-06$ & $0.5070 \mathrm{E}+03$ & $0.1570 \mathrm{E}+03$ \\
12.0 & $0.3325 \mathrm{E}-06$ & $0.5787 \mathrm{E}+03$ & $0.1682 \mathrm{E}+03$ & $0.3323 \mathrm{E}-06$ & $0.5790 \mathrm{E}+03$ & $0.1682 \mathrm{E}+03$ \\
13.5 & $0.2804 \mathrm{E}-06$ & $0.6507 \mathrm{E}+03$ & $0.1788 \mathrm{E}+03$ & $0.2803 \mathrm{E}-06$ & $0.6510 \mathrm{E}+03$ & $0.1788 \mathrm{E}+03$ \\
15.0 & $0.2406 \mathrm{E}-06$ & $0.7226 \mathrm{E}+03$ & $0.1887 \mathrm{E}+03$ & $0.2405 \mathrm{E}-06$ & $0.7230 \mathrm{E}+03$ & $0.1887 \mathrm{E}+03$ \\
16.5 & $0.2094 \mathrm{E}-06$ & $0.7946 \mathrm{E}+03$ & $0.1981 \mathrm{E}+03$ & $0.2093 \mathrm{E}-06$ & $0.7950 \mathrm{E}+03$ & $0.1981 \mathrm{E}+03$ \\
18.0 & $0.1844 \mathrm{E}-06$ & $0.8665 \mathrm{E}+03$ & $0.2071 \mathrm{E}+03$ & $0.1843 \mathrm{E}-06$ & $0.8670 \mathrm{E}+03$ & $0.2071 \mathrm{E}+03$ \\
19.5 & $0.1640 \mathrm{E}-06$ & $0.9385 \mathrm{E}+03$ & $0.2158 \mathrm{E}+03$ & $0.1639 \mathrm{E}-06$ & $0.9390 \mathrm{E}+03$ & $0.2158 \mathrm{E}+03$ \\
21.0 & $0.1471 \mathrm{E}-06$ & $0.1010 \mathrm{E}+04$ & $0.2241 \mathrm{E}+03$ & $0.1471 \mathrm{E}-06$ & $0.1011 \mathrm{E}+04$ & $0.2241 \mathrm{E}+03$ \\
22.5 & $0.1329 \mathrm{E}-06$ & $0.1082 \mathrm{E}+04$ & $0.2321 \mathrm{E}+03$ & $0.1329 \mathrm{E}-06$ & $0.1083 \mathrm{E}+04$ & $0.23 .21 \mathrm{E}+03$ \\
24.0 & $0.1249 \mathrm{E}-06$ & $0.1118 \mathrm{E}+04$ & $0.2398 \mathrm{E}+03$ & $0.1248 \mathrm{E}-06$ & $0.1118 \mathrm{E}+04$ & $0.2398 \mathrm{E}+03$ \\
25.5 & $0.1177 \mathrm{E}-06$ & $0.1152 \mathrm{E}+04$ & $0.2473 \mathrm{E}+03$ & $0.1177 \mathrm{E}-06$ & $0.1153 \mathrm{E}+04$ & $0.2473 \mathrm{E}+03$ \\
27.0 & $0.1113 \mathrm{E}-06$ & $0.1185 \mathrm{E}+04$ & $0.2545 \mathrm{E}+03$ & $0.1113 \mathrm{E}-06$ & $0.1186 \mathrm{E}+04$ & $0.2545 \mathrm{E}+03$ \\
28.5 & $0.1056 \mathrm{E}-06$ & $0.1218 \mathrm{E}+04$ & $0.2616 \mathrm{E}+03$ & $0.1056 \mathrm{E}-06$ & $0.1218 \mathrm{E}+04$ & $0.2616 \mathrm{E}+03$ \\
30.0 & $0.1004 \mathrm{E}-06$ & $0.1249 \mathrm{E}+04$ & $0.2684 \mathrm{E}+03$ & $0.1004 \mathrm{E}-06$ & $0.1250 \mathrm{E}+04$ & $0.2684 \mathrm{E}+03$ \\
\hline
\end{tabular}


Table 47. Same as Table 33, but for case 15

\begin{tabular}{|c|c|c|c|c|c|c|}
\hline $\begin{array}{c}\mathrm{x} \\
(\mathrm{km})\end{array}$ & $\begin{array}{c}\text { Dose (NS) } \\
(\mathrm{rem})\end{array}$ & $\begin{array}{c}\sigma_{\mathrm{y}}(\mathrm{NS}) \\
(\mathrm{m})\end{array}$ & $\begin{array}{c}\sigma_{\mathrm{z}}(\mathrm{NS}) \\
(\mathrm{m})\end{array}$ & $\begin{array}{c}\text { Dose }(\mathrm{AS}) \\
(\mathrm{rem})\end{array}$ & $\begin{array}{c}\sigma_{\mathrm{y}}(\mathrm{AS}) \\
(\mathrm{m})\end{array}$ & $\begin{array}{c}\sigma_{z}(\mathrm{AS}) \\
(\mathrm{m})\end{array}$ \\
\hline 1.8 & $0.1921 \mathrm{E}-05$ & $0.8940 \mathrm{E}+02$ & $0.5919 \mathrm{E}+02$ & $0.1921 \mathrm{E}-05$ & $0.8944 \mathrm{E}+02$ & $0.5919 \mathrm{E}+02$ \\
3.6 & $0.8767 \mathrm{E}-06$ & $0.1757 \mathrm{E}+03$ & $0.8843 \mathrm{E}+02$ & $0.8765 \mathrm{E}-06$ & $0.1758 \mathrm{E}+03$ & $0.8843 \mathrm{E}+02$ \\
5.4 & $0.5126 \mathrm{E}-06$ & $0.2621 \mathrm{E}+03$ & $0.1105 \mathrm{E}+03$ & $0.5124 \mathrm{E}-06$ & $0.2622 \mathrm{E}+03$ & $0.1105 \mathrm{E}+03$ \\
7.2 & $0.3442 \mathrm{E}-06$ & $0.3484 \mathrm{E}+03$ & $0.1288 \mathrm{E}+03$ & $0.3441 \mathrm{E}-06$ & $0.3486 \mathrm{E}+03$ & $0.1288 \mathrm{E}+03$ \\
9.0 & $0.2511 \mathrm{E}-06$ & $0.4348 \mathrm{E}+03$ & $0.1449 \mathrm{E}+03$ & $0.2510 \mathrm{E}-06$ & $0.4350 \mathrm{E}+03$ & $0.1449 \mathrm{E}+03$ \\
10.8 & $0.1935 \mathrm{E}-06$ & $0.5211 \mathrm{E}+03$ & $0.1593 \mathrm{E}+03$ & $0.1934 \mathrm{E}-06$ & $0.5214 \mathrm{E}+03$ & $0.1593 \mathrm{E}+03$ \\
12.6 & $0.1549 \mathrm{E}-06$ & $0.6075 \mathrm{E}+03$ & $0.1725 \mathrm{E}+03$ & $0.1549 \mathrm{E}-06$ & $0.6078 \mathrm{E}+03$ & $0.1725 \mathrm{E}+03$ \\
14.4 & $0.1277 \mathrm{E}-06$ & $0.6938 \mathrm{E}+03$ & $0.1848 \mathrm{E}+03$ & $0.1276 \mathrm{E}-06$ & $0.6942 \mathrm{E}+03$ & $0.1848 \mathrm{E}+03$ \\
16.2 & $0.1075 \mathrm{E}-06$ & $0.7802 \mathrm{E}+03$ & $0.1963 \mathrm{E}+03$ & $0.1075 \mathrm{E}-06$ & $0.7806 \mathrm{E}+03$ & $0.1963 \mathrm{E}+03$ \\
18.0 & $0.9220 \mathrm{E}-07$ & $0.8665 \mathrm{E}+03$ & $0.2071 \mathrm{E}+03$ & $0.9216 \mathrm{E}-07$ & $0.8670 \mathrm{E}+03$ & $0.2071 \mathrm{E}+03$ \\
19.8 & $0.8019 \mathrm{E}-07$ & $0.9529 \mathrm{E}+03$ & $0.2175 \mathrm{E}+03$ & $0.8016 \mathrm{E}-07$ & $0.9534 \mathrm{E}+03$ & $0.2175 \mathrm{E}+03$ \\
21.6 & $0.7058 \mathrm{E}-07$ & $0.1039 \mathrm{E}+04$ & $0.2273 \mathrm{E}+03$ & $0.7055 \mathrm{E}-07$ & $0.1040 \mathrm{E}+04$ & $0.2273 \mathrm{E}+03$ \\
23.4 & $0.6399 \mathrm{E}-07$ & $0.1104 \mathrm{E}+04$ & $0.2367 \mathrm{E}+03$ & $0.6396 \mathrm{E}-07$ & $0.1104 \mathrm{E}+04$ & $0.2367 \mathrm{E}+03$ \\
25.2 & $0.5954 \mathrm{E}-07$ & $0.1145 \mathrm{E}+04$ & $0.2458 \mathrm{E}+03$ & $0.5951 \mathrm{E}-07$ & $0.1146 \mathrm{E}+04$ & $0.2458 \mathrm{E}+03$ \\
27.0 & $0.5566 \mathrm{E}-07$ & $0.1185 \mathrm{E}+04$ & $0.2545 \mathrm{E}+03$ & $0.5564 \mathrm{E}-07$ & $0.1186 \mathrm{E}+04$ & $0.2545 \mathrm{E}+03$ \\
28.8 & $0.5226 \mathrm{E}-07$ & $0.1224 \mathrm{E}+04$ & $0.2630 \mathrm{E}+03$ & $0.5224 \mathrm{E}-07$ & $0.1225 \mathrm{E}+04$ & $0.2630 \mathrm{E}+03$ \\
30.6 & $0.4926 \mathrm{E}-07$ & $0.1262 \mathrm{E}+04$ & $0.2711 \mathrm{E}+03$ & $0.4923 \mathrm{E}-07$ & $0.1262 \mathrm{E}+04$ & $0.2711 \mathrm{E}+03$ \\
\hline
\end{tabular}


Table 48. Comparison of the analytic solution (AS), Eq. (13), and the numerical results (NS) calculated by 2DPUF using the input parameters given for case 1 (default case) listed in Tables 1 and 2

\begin{tabular}{|r|c|c|c|c|}
\hline $\begin{array}{c}\mathrm{X} \\
(\mathrm{km})\end{array}$ & $\begin{array}{c}\text { Dose (NS) } \\
(\text { Rem })\end{array}$ & $\begin{array}{c}\text { Dose (AS) } \\
(\text { Rem })\end{array}$ & $\begin{array}{c}\sigma_{\mathrm{y}}(\mathrm{NS}) \\
(\mathrm{m})\end{array}$ & $\begin{array}{c}\sigma_{\mathrm{z}}(\mathrm{NS}) \\
(\mathrm{m})\end{array}$ \\
\hline 2.0 & $0.194 \mathrm{E}-05$ & $0.1944 \mathrm{E}-05$ & $0.9904 \mathrm{E}+02$ & $0.9903 \mathrm{E}+02$ \\
4.0 & $0.561 \mathrm{E}-06$ & $0.5770 \mathrm{E}-06$ & $0.1950 \mathrm{E}+03$ & $0.1950 \mathrm{E}+03$ \\
6.0 & $0.259 \mathrm{E}-06$ & $0.2662 \mathrm{E}-06$ & $0.2910 \mathrm{E}+03$ & $0.2910 \mathrm{E}+03$ \\
8.0 & $0.149 \mathrm{E}-06$ & $0.1520 \mathrm{E}-06$ & $0.3870 \mathrm{E}+03$ & $0.3870 \mathrm{E}+03$ \\
10.0 & $0.115 \mathrm{E}-06$ & $0.1179 \mathrm{E}-06$ & $0.4830 \mathrm{E}+03$ & $0.4000 \mathrm{E}+03$ \\
12.0 & $0.958 \mathrm{E}-07$ & $0.9836 \mathrm{E}-07$ & $0.5790 \mathrm{E}+03$ & $0.4000 \mathrm{E}+03$ \\
14.0 & $0.822 \mathrm{E}-07$ & $0.8437 \mathrm{E}-07$ & $0.6750 \mathrm{E}+03$ & $0.4000 \mathrm{E}+03$ \\
16.0 & $0.720 \mathrm{E}-07$ & $0.7386 \mathrm{E}-07$ & $0.7710 \mathrm{E}+03$ & $0.4000 \mathrm{E}+03$ \\
18.0 & $0.641 \mathrm{E}-07$ & $0.6569 \mathrm{E}-07$ & $0.8670 \mathrm{E}+03$ & $0.4000 \mathrm{E}+03$ \\
20.0 & $0.576 \mathrm{E}-07$ & $0.5914 \mathrm{E}-07$ & $0.9630 \mathrm{E}+03$ & $0.4000 \mathrm{E}+03$ \\
22.0 & $0.524 \mathrm{E}-07$ & $0.5378 \mathrm{E}-07$ & $0.1059 \mathrm{E}+04$ & $0.4000 \mathrm{E}+03$ \\
24.0 & $0.480 \mathrm{E}-07$ & $0.4931 \mathrm{E}-07$ & $0.1155 \mathrm{E}+04$ & $0.4000 \mathrm{E}+03$ \\
26.0 & $0.443 \mathrm{E}-07$ & $0.4552 \mathrm{E}-07$ & $0.1251 \mathrm{E}+04$ & $0.4000 \mathrm{E}+03$ \\
28.0 & $0.412 \mathrm{E}-07$ & $0.4228 \mathrm{E}-07$ & $0.1347 \mathrm{E}+04$ & $0.4000 \mathrm{E}+03$ \\
30.0 & $0.385 \mathrm{E}-07$ & $0.3947 \mathrm{E}-07$ & $0.1443 \mathrm{E}+04$ & $0.4000 \mathrm{E}+03$ \\
\hline
\end{tabular}

Table 49. Same as Table 48 , but for case 3

\begin{tabular}{|r|c|c|c|c|}
\hline $\begin{array}{c}\mathbf{x} \\
(\mathrm{km})\end{array}$ & $\begin{array}{c}\text { Dose (NS) } \\
(\mathrm{Rem})\end{array}$ & $\begin{array}{c}\text { Dose (AS) } \\
(\mathrm{Rem})\end{array}$ & $\begin{array}{c}\sigma_{\mathrm{y}}(\mathrm{NS}) \\
(\mathrm{m})\end{array}$ & $\begin{array}{c}\sigma_{\mathbf{z}}(\mathrm{NS}) \\
(\mathrm{m})\end{array}$ \\
\hline 2.0 & $0.939 \mathrm{E}+01$ & $0.9399 \mathrm{E}+01$ & $0.9904 \mathrm{E}+02$ & $0.9903 \mathrm{E}+02$ \\
4.0 & $0.271 \mathrm{E}+01$ & $0.2790 \mathrm{E}+01$ & $0.1950 \mathrm{E}+03$ & $0.1950 \mathrm{E}+03$ \\
6.0 & $0.125 \mathrm{E}+01$ & $0.1287 \mathrm{E}+01$ & $0.2910 \mathrm{E}+03$ & $0.2910 \mathrm{E}+03$ \\
8.0 & $0.720 \mathrm{E}-00$ & $0.7347 \mathrm{E}+00$ & $0.3870 \mathrm{E}+03$ & $0.3870 \mathrm{E}+03$ \\
10.0 & $0.555 \mathrm{E}-00$ & $0.5700 \mathrm{E}+00$ & $0.4830 \mathrm{E}+03$ & $0.4000 \mathrm{E}+03$ \\
12.0 & $0.463 \mathrm{E}-00$ & $0.4755 \mathrm{E}+00$ & $0.5790 \mathrm{E}+03$ & $0.4000 \mathrm{E}+03$ \\
14.0 & $0.397 \mathrm{E}-00$ & $0.4079 \mathrm{E}+00$ & $0.6750 \mathrm{E}+03$ & $0.4000 \mathrm{E}+03$ \\
16.0 & $0.348 \mathrm{E}-00$ & $0.3571 \mathrm{E}+00$ & $0.7710 \mathrm{E}+03$ & $0.4000 \mathrm{E}+03$ \\
18.0 & $0.310 \mathrm{E}-00$ & $0.3175 \mathrm{E}+00$ & $0.8670 \mathrm{E}+03$ & $0.4000 \mathrm{E}+03$ \\
20.0 & $0.278 \mathrm{E}-00$ & $0.2859 \mathrm{E}+00$ & $0.9630 \mathrm{E}+03$ & $0.4000 \mathrm{E}+03$ \\
22.0 & $0.253 \mathrm{E}-00$ & $0.2600 \mathrm{E}+00$ & $0.1059 \mathrm{E}+04$ & $0.4000 \mathrm{E}+03$ \\
24.0 & $0.232 \mathrm{E}-00$ & $0.2384 \mathrm{E}+00$ & $0.1155 \mathrm{E}+04$ & $0.4000 \mathrm{E}+03$ \\
26.0 & $0.214 \mathrm{E}-00$ & $0.2201 \mathrm{E}+00$ & $0.1251 \mathrm{E}+04$ & $0.4000 \mathrm{E}+03$ \\
28.0 & $0.199 \mathrm{E}-00$ & $0.2044 \mathrm{E}+00$ & $0.1347 \mathrm{E}+04$ & $0.4000 \mathrm{E}+03$ \\
30.0 & $0.186 \mathrm{E}-00$ & $0.1908 \mathrm{E}+00$ & $0.1443 \mathrm{E}+04$ & $0.4000 \mathrm{E}+03$ \\
\hline
\end{tabular}


Table 50. Same as Table 48 , but for case 4

\begin{tabular}{|r|c|c|c|c|}
\hline $\begin{array}{c}\mathrm{x} \\
(\mathrm{km})\end{array}$ & $\begin{array}{c}\text { Dose (NS) } \\
(\text { Rem })\end{array}$ & $\begin{array}{c}\text { Dose }(\mathrm{AS}) \\
(\text { Rem })\end{array}$ & $\begin{array}{c}\sigma_{\mathrm{y}}(\mathrm{NS}) \\
(\mathrm{m})\end{array}$ & $\begin{array}{c}\sigma_{\mathrm{z}}(\mathrm{NS}) \\
(\mathrm{m})\end{array}$ \\
\hline 2.0 & $0.661 \mathrm{E}-05$ & $0.6617 \mathrm{E}-05$ & $0.9904 \mathrm{E}+02$ & $0.9903 \mathrm{E}+02$ \\
4.0 & $0.187 \mathrm{E}-05$ & $0.1920 \mathrm{E}-05$ & $0.1950 \mathrm{E}+03$ & $0.1950 \mathrm{E}+03$ \\
6.0 & $0.844 \mathrm{E}-06$ & $0.8663 \mathrm{E}-06$ & $0.2910 \mathrm{E}+03$ & $0.2910 \mathrm{E}+03$ \\
8.0 & $0.474 \mathrm{E}-06$ & $0.4836 \mathrm{E}-06$ & $0.3870 \mathrm{E}+03$ & $0.3870 \mathrm{E}+03$ \\
10.0 & $0.357 \mathrm{E}-06$ & $0.3668 \mathrm{E}-06$ & $0.4830 \mathrm{E}+03$ & $0.4000 \mathrm{E}+03$ \\
12.0 & $0.292 \mathrm{E}-06$ & $0.2992 \mathrm{E}-06$ & $0.5790 \mathrm{E}+03$ & $0.4000 \mathrm{E}+03$ \\
14.0 & $0.244 \mathrm{E}-06$ & $0.2510 \mathrm{E}-06$ & $0.6750 \mathrm{E}+03$ & $0.4000 \mathrm{E}+03$ \\
16.0 & $0.209 \mathrm{E}-06$ & $0.2149 \mathrm{E}-06$ & $0.7710 \mathrm{E}+03$ & $0.4000 \mathrm{E}+03$ \\
18.0 & $0.182 \mathrm{E}-06$ & $0.1868 \mathrm{E}-06$ & $0.8670 \mathrm{E}+03$ & $0.4000 \mathrm{E}+03$ \\
20.0 & $0.160 \mathrm{E}-06$ & $0.1645 \mathrm{E}-06$ & $0.9630 \mathrm{E}+03$ & $0.4000 \mathrm{E}+03$ \\
22.0 & $0.142 \mathrm{E}-06$ & $0.1463 \mathrm{E}-06$ & $0.1059 \mathrm{E}+04$ & $0.4000 \mathrm{E}+03$ \\
24.0 & $0.127 \mathrm{E}-06$ & $0.1311 \mathrm{E}-06$ & $0.1155 \mathrm{E}+04$ & $0.4000 \mathrm{E}+03$ \\
26.0 & $0.115 \mathrm{E}-06$ & $0.1184 \mathrm{E}-06$ & $0.1251 \mathrm{E}+04$ & $0.4000 \mathrm{E}+03$ \\
28.0 & $0.105 \mathrm{E}-06$ & $0.1075 \mathrm{E}-06$ & $0.1347 \mathrm{E}+04$ & $0.4000 \mathrm{E}+03$ \\
30.0 & $0.958 \mathrm{E}-07$ & $0.9812 \mathrm{E}-07$ & $0.1443 \mathrm{E}+04$ & $0.4000 \mathrm{E}+03$ \\
\hline
\end{tabular}

Table 51. Samt as Table 48 , but for case 5

\begin{tabular}{|c|c|c|c|c|}
\hline $\begin{array}{c}\mathrm{x} \\
(\mathrm{km})\end{array}$ & $\begin{array}{c}\text { Dose (NS) } \\
(\text { Rem })\end{array}$ & $\begin{array}{c}\text { Dose }(\mathrm{AS}) \\
(\text { Rem })\end{array}$ & $\begin{array}{c}\sigma_{\mathrm{y}}(\mathrm{NS}) \\
(\mathrm{m})\end{array}$ & $\begin{array}{c}\sigma_{\mathrm{z}}(\mathrm{NS}) \\
(\mathrm{m})\end{array}$ \\
\hline 2.0 & $0.194 \mathrm{E}-05$ & $0.1944 \mathrm{E}-05$ & $0.9904 \mathrm{E}+02$ & $0.9903 \mathrm{E}+02$ \\
4.0 & $0.561 \mathrm{E}-06$ & $0.5770 \mathrm{E}-06$ & $0.1950 \mathrm{E}+03$ & $0.1950 \mathrm{E}+03$ \\
6.0 & $0.259 \mathrm{E}-06$ & $0.2662 \mathrm{E}-06$ & $0.2910 \mathrm{E}+03$ & $0.2910 \mathrm{E}+03$ \\
8.0 & $0.148 \mathrm{E}-06$ & $0.1520 \mathrm{E}-06$ & $0.3870 \mathrm{E}+03$ & $0.3870 \mathrm{E}+03$ \\
10.0 & $0.955 \mathrm{E}-07$ & $0.9801 \mathrm{E}-07$ & $0.4830 \mathrm{E}+03$ & $0.4829 \mathrm{E}+03$ \\
12.0 & $0.666 \mathrm{E}-07$ & $0.6837 \mathrm{E}-07$ & $0.5790 \mathrm{E}+03$ & $0.5789 \mathrm{E}+03$ \\
14.0 & $0.491 \mathrm{E}-07$ & $0.5038 \mathrm{E}-07$ & $0.6750 \mathrm{E}+03$ & $0.6749 \mathrm{E}+03$ \\
16.0 & $0.379 \mathrm{E}-07$ & $0.3865 \mathrm{E}-07$ & $0.7710 \mathrm{E}+03$ & $0.7709 \mathrm{E}+03$ \\
18.0 & $0.324 \mathrm{E}-07$ & $0.3313 \mathrm{E}-07$ & $0.8670 \mathrm{E}+03$ & $0.8000 \mathrm{E}+03$ \\
20.0 & $0.290 \mathrm{E}-07$ & $0.2983 \mathrm{E}-07$ & $0.9630 \mathrm{E}+03$ & $0.8000 \mathrm{E}+03$ \\
22.0 & $0.264 \mathrm{E}-07$ & $0.2712 \mathrm{E}-07$ & $0.1059 \mathrm{E}+04$ & $0.8000 \mathrm{E}+03$ \\
24.0 & $0.242 \mathrm{E}-07$ & $0.2487 \mathrm{E}-07$ & $0.1155 \mathrm{E}+04$ & $0.8000 \mathrm{E}+03$ \\
26.0 & $0.223 \mathrm{E}-07$ & $0.2296 \mathrm{E}-07$ & $0.1251 \mathrm{E}+04$ & $0.8000 \mathrm{E}+03$ \\
28.0 & $0.208 \mathrm{E}-07$ & $0.2132 \mathrm{E}-07$ & $0.1347 \mathrm{E}+04$ & $0.8000 \mathrm{E}+03$ \\
30.0 & $0.194 \mathrm{E}-07$ & $0.1991 \mathrm{E}-07$ & $0.1443 \mathrm{E}+04$ & $0.8000 \mathrm{E}+03$ \\
\hline
\end{tabular}


Table 52. Same as Table 48, but for case 6

\begin{tabular}{|r|c|c|c|c|}
\hline $\begin{array}{c}\mathrm{x} \\
(\mathrm{km})\end{array}$ & $\begin{array}{c}\text { Dose }(\mathrm{NS}) \\
(\text { Rem })\end{array}$ & $\begin{array}{c}\text { Dose }(\mathrm{AS}) \\
(\text { Rem })\end{array}$ & $\begin{array}{c}\sigma_{\mathrm{y}}(\mathrm{NS}) \\
(\mathrm{m})\end{array}$ & $\begin{array}{c}\sigma_{\mathrm{z}}(\mathrm{NS}) \\
(\mathrm{m})\end{array}$ \\
\hline 2.0 & $0.387 \mathrm{E}-06$ & $0.4087 \mathrm{E}-06$ & $0.2334 \mathrm{E}+03$ & $0.2334 \mathrm{E}+03$ \\
4.0 & $0.100 \mathrm{E}-06$ & $0.1062 \mathrm{E}-06$ & $0.4638 \mathrm{E}+03$ & $0.4638 \mathrm{E}+03$ \\
6.0 & $0.454 \mathrm{E}-07$ & $0.4764 \mathrm{E}-07$ & $0.6942 \mathrm{E}+03$ & $0.6942 \mathrm{E}+03$ \\
8.0 & $0.295 \mathrm{E}-07$ & $0.3107 \mathrm{E}-07$ & $0.9246 \mathrm{E}+03$ & $0.8000 \mathrm{E}+03$ \\
10.0 & $0.235 \mathrm{E}-07$ & $0.2487 \mathrm{E}-07$ & $0.1155 \mathrm{E}+04$ & $0.8000 \mathrm{E}+03$ \\
12.0 & $0.195 \mathrm{E}-07$ & $0.2073 \mathrm{E}-07$ & $0.1385 \mathrm{E}+04$ & $0.8000 \mathrm{E}+03$ \\
14.0 & $0.168 \mathrm{E}-07$ & $0.1778 \mathrm{E}-07$ & $0.1616 \mathrm{E}+04$ & $0.8000 \mathrm{E}+03$ \\
16.0 & $0.147 \mathrm{E}-07$ & $0.1556 \mathrm{E}-07$ & $0.1846 \mathrm{E}+04$ & $0.8000 \mathrm{E}+03$ \\
18.0 & $0.131 \mathrm{E}-07$ & $0.1383 \mathrm{E}-07$ & $0.2076 \mathrm{E}+04$ & $0.8000 \mathrm{E}+03$ \\
20.0 & $0.118 \mathrm{E}-07$ & $0.1245 \mathrm{E}-07$ & $0.2307 \mathrm{E}+04$ & $0.8000 \mathrm{E}+03$ \\
22.0 & $0.107 \mathrm{E}-07$ & $0.1132 \mathrm{E}-07$ & $0.2537 \mathrm{E}+04$ & $0.8000 \mathrm{E}+03$ \\
24.0 & $0.982 \mathrm{E}-08$ & $0.1038 \mathrm{E}-07$ & $0.2768 \mathrm{E}+04$ & $0.8000 \mathrm{E}+03$ \\
26.0 & $0.904 \mathrm{E}-08$ & $0.9581 \mathrm{E}-08$ & $0.2998 \mathrm{E}+04$ & $0.8000 \mathrm{E}+03$ \\
28.0 & $0.842 \mathrm{E}-08$ & $0.8897 \mathrm{E}-08$ & $0.3228 \mathrm{E}+04$ & $0.8000 \mathrm{E}+03$ \\
30.0 & $0.786 \mathrm{E}-08$ & $0.8304 \mathrm{E}-08$ & $0.3459 \mathrm{E}+04$ & $0.8000 \mathrm{E}+03$ \\
\hline
\end{tabular}

Table 53. Same as Table 48 , but for case 7

\begin{tabular}{|r|c|c|c|c|}
\hline $\begin{array}{c}\mathrm{x} \\
(\mathrm{km})\end{array}$ & $\begin{array}{c}\text { Dose }(\mathrm{NS}) \\
(\text { Rem })\end{array}$ & $\begin{array}{c}\text { Dose }(\mathrm{AS}) \\
(\text { Rem })\end{array}$ & $\begin{array}{c}\sigma_{\mathrm{y}}(\mathrm{NS}) \\
(\mathrm{m})\end{array}$ & $\begin{array}{c}\sigma_{\mathrm{z}}(\mathrm{NS}) \\
(\mathrm{m})\end{array}$ \\
\hline 2.0 & $0.387 \mathrm{E}-06$ & $0.4087 \mathrm{E}-06$ & $0.2334 \mathrm{E}+03$ & $0.2334 \mathrm{E}+03$ \\
4.0 & $0.116 \mathrm{E}-06$ & $0.1228 \mathrm{E}-06$ & $0.4638 \mathrm{E}+03$ & $0.4000 \mathrm{E}+03$ \\
6.0 & $0.776 \mathrm{E}-07$ & $0.8204 \mathrm{E}-07$ & $0.6942 \mathrm{E}+03$ & $0.4000 \mathrm{E}+03$ \\
8.0 & $0.583 \mathrm{E}-07$ & $0.6159 \mathrm{E}-07$ & $0.9246 \mathrm{E}+03$ & $0.4000 \mathrm{E}+03$ \\
10.0 & $0.467 \mathrm{E}-07$ & $0.4931 \mathrm{E}-07$ & $0.1155 \mathrm{E}+04$ & $0.4000 \mathrm{E}+03$ \\
12.0 & $0.388 \mathrm{E}-07$ & $0.4111 \mathrm{E}-07$ & $0.1385 \mathrm{E}+04$ & $0.4000 \mathrm{E}+03$ \\
14.0 & $0.334 \mathrm{E}-07$ & $0.3525 \mathrm{E}-07$ & $0.1616 \mathrm{E}+04$ & $0.4000 \mathrm{E}+03$ \\
16.0 & $0.292 \mathrm{E}-07$ & $0.3085 \mathrm{E}-07$ & $0.1846 \mathrm{E}+04$ & $0.4000 \mathrm{E}+03$ \\
18.0 & $0.260 \mathrm{E}-07$ & $0.2743 \mathrm{E}-07$ & $0.2076 \mathrm{E}+04$ & $0.4000 \mathrm{E}+03$ \\
20.0 & $0.234 \mathrm{E}-07$ & $0.2469 \mathrm{E}-07$ & $0.2307 \mathrm{E}+04$ & $0.4000 \mathrm{E}+03$ \\
22.0 & $0.212 \mathrm{E}-07$ & $0.2244 \mathrm{E}-07$ & $0.2537 \mathrm{E}+04$ & $0.4000 \mathrm{E}+03$ \\
24.0 & $0.195 \mathrm{E}-07$ & $0.2058 \mathrm{E}-07$ & $0.2768 \mathrm{E}+04$ & $0.4000 \mathrm{E}+03$ \\
26.0 & $0.179 \mathrm{E}-07$ & $0.1900 \mathrm{E}-07$ & $0.2998 \mathrm{E}+04$ & $0.4000 \mathrm{E}+03$ \\
28.0 & $0.167 \mathrm{E}-07$ & $0.1764 \mathrm{E}-07$ & $0.3228 \mathrm{E}+04$ & $0.4000 \mathrm{E}+03$ \\
30.0 & $0.156 \mathrm{E}-07$ & $0.1646 \mathrm{E}-07$ & $0.3459 \mathrm{E}+04$ & $0.4000 \mathrm{E}+03$ \\
\hline
\end{tabular}


Table 54. Same as Table 48 , but for case 8

\begin{tabular}{|r|c|c|c|c|}
\hline $\begin{array}{c}\mathrm{x} \\
(\mathrm{km})\end{array}$ & $\begin{array}{c}\text { Dose (NS) } \\
(\text { Rem) }\end{array}$ & $\begin{array}{c}\text { Dose (AS) } \\
(\text { Rem })\end{array}$ & $\begin{array}{c}\sigma_{\mathrm{y}}(\mathrm{NS}) \\
(\mathrm{m})\end{array}$ & $\begin{array}{c}\sigma_{\mathrm{z}}(\mathrm{NS}) \\
(\mathrm{m})\end{array}$ \\
\hline 2.0 & $0.676 \mathrm{E}-06$ & $0.7021 \mathrm{E}-06$ & $0.1758 \mathrm{E}+03$ & $0.1758 \mathrm{E}+03$ \\
4.0 & $0.180 \mathrm{E}-06$ & $0.1868 \mathrm{E}-06$ & $0.3486 \mathrm{E}+03$ & $0.3485 \mathrm{E}+03$ \\
6.0 & $0.104 \mathrm{E}-06$ & $0.1092 \mathrm{E}-06$ & $0.5214 \mathrm{E}+03$ & $0.4000 \mathrm{E}+03$ \\
8.0 & $0.783 \mathrm{E}-07$ & $0.8204 \mathrm{E}-07$ & $0.6942 \mathrm{E}+03$ & $0.4000 \mathrm{E}+03$ \\
10.0 & $0.630 \mathrm{E}-07$ & $0.6569 \mathrm{E}-07$ & $0.8670 \mathrm{E}+03$ & $0.4000 \mathrm{E}+03$ \\
12.0 & $0.525 \mathrm{E}-07$ & $0.5477 \mathrm{E}-07$ & $0.1040 \mathrm{E}+04$ & $0.4000 \mathrm{E}+03$ \\
14.0 & $0.450 \mathrm{E}-07$ & $0.4697 \mathrm{E}-07$ & $0.1213 \mathrm{E}+04$ & $0.4000 \mathrm{E}+03$ \\
16.0 & $0.393 \mathrm{E}-07$ & $0.4111 \mathrm{E}-07$ & $0.1385 \mathrm{E}+04$ & $0.4000 \mathrm{E}+03$ \\
18.0 & $0.351 \mathrm{E}-07$ & $0.3655 \mathrm{E}-07$ & $0.1558 \mathrm{E}+04$ & $0.4000 \mathrm{E}+03$ \\
20.0 & $0.314 \mathrm{E}-07$ & $0.3290 \mathrm{E}-07$ & $0.1731 \mathrm{E}+04$ & $0.4000 \mathrm{E}+03$ \\
22.0 & $0.286 \mathrm{E}-07$ & $0.2991 \mathrm{E}-07$ & $0.1904 \mathrm{E}+04$ & $0.4000 \mathrm{E}+03$ \\
24.0 & $0.262 \mathrm{E}-07$ & $0.2743 \mathrm{E}-07$ & $0.2076 \mathrm{E}+04$ & $0.4000 \mathrm{E}+03$ \\
26.0 & $0.242 \mathrm{E}-07$ & $0.2532 \mathrm{E}-07$ & $0.2249 \mathrm{E}+04$ & $0.4000 \mathrm{E}+03$ \\
28.0 & $0.225 \mathrm{E}-07$ & $0.2351 \mathrm{E}-07$ & $0.2422 \mathrm{E}+04$ & $0.4000 \mathrm{E}+03$ \\
30.0 & $0.210 \mathrm{E}-07$ & $0.2195 \mathrm{E}-07$ & $0.2595 \mathrm{E}+04$ & $0.4000 \mathrm{E}+03$ \\
\hline
\end{tabular}

Table 55. Same as Table 48, but for case 9

\begin{tabular}{|r|c|c|c|c|}
\hline $\begin{array}{c}\mathrm{x} \\
(\mathrm{km})\end{array}$ & $\begin{array}{c}\text { Dose (NS) } \\
(\mathrm{Rem})\end{array}$ & $\begin{array}{c}\text { Dose (AS) } \\
(\text { Rem })\end{array}$ & $\begin{array}{c}\sigma_{\mathrm{y}}(\mathrm{NS}) \\
(\mathrm{m})\end{array}$ & $\begin{array}{c}\sigma_{\mathrm{z}}(\mathrm{NS}) \\
(\mathrm{m})\end{array}$ \\
\hline 2.0 & $0.110 \mathrm{E}-5$ & $0.1106 \mathrm{E}-05$ & $0.1374 \mathrm{E}+03$ & $0.1375 \mathrm{E}+03$ \\
4.0 & $0.294 \mathrm{E}-06$ & $0.3041 \mathrm{E}-06$ & $0.2718 \mathrm{E}+03$ & $0.2719 \mathrm{E}+03$ \\
6.0 & $0.138 \mathrm{E}-06$ & $0.1402 \mathrm{E}-06$ & $0.4062 \mathrm{E}+03$ & $0.4000 \mathrm{E}+03$ \\
8.0 & $0.102 \mathrm{E}-06$ & $0.1053 \mathrm{E}-06$ & $0.5406 \mathrm{E}+03$ & $0.4000 \mathrm{E}+03$ \\
10.0 & $0.816 \mathrm{E}-07$ & $0.8437 \mathrm{E}-07$ & $0.6750 \mathrm{E}+03$ & $0.4000 \mathrm{E}+03$ \\
12.0 & $0.679 \mathrm{E}-07$ & $0.7036 \mathrm{E}-07$ & $0.8094 \mathrm{E}+03$ & $0.4000 \mathrm{E}+03$ \\
14.0 & $0.581 \mathrm{E}-07$ & $0.6034 \mathrm{E}-07$ & $0.9438 \mathrm{E}+03$ & $0.4000 \mathrm{E}+03$ \\
16.0 & $0.509 \mathrm{E}-07$ & $0.5282 \mathrm{E}-07$ & $0.1078 \mathrm{E}+04$ & $0.4000 \mathrm{E}+03$ \\
18.0 & $0.454 \mathrm{E}-07$ & $0.4697 \mathrm{E}-07$ & $0.1213 \mathrm{E}+04$ & $0.4000 \mathrm{E}+03$ \\
20.0 & $0.408 \mathrm{E}-07$ & $0.4228 \mathrm{E}-07$ & $0.1347 \mathrm{E}+04$ & $0.4000 \mathrm{E}+03$ \\
22.0 & $0.372 \mathrm{E}-07$ & $0.3844 \mathrm{E}-07$ & $0.1481 \mathrm{E}+04$ & $0.4000 \mathrm{E}+03$ \\
24.0 & $0.340 \mathrm{E}-07$ & $0.3525 \mathrm{E}-07$ & $0.1616 \mathrm{E}+04$ & $0.4000 \mathrm{E}+03$ \\
26.0 & $0.314 \mathrm{E}-07$ & $0.3254 \mathrm{E}-07$ & $0.1750 \mathrm{E}+04$ & $0.4000 \mathrm{E}+03$ \\
28.0 & $0.291 \mathrm{E}-07$ & $0.3022 \mathrm{E}-07$ & $0.1885 \mathrm{E}+04$ & $0.4000 \mathrm{E}+03$ \\
30.0 & $0.273 \mathrm{E}-07$ & $0.2821 \mathrm{E}-07$ & $0.2019 \mathrm{E}+04$ & $0.4000 \mathrm{E}+03$ \\
\hline
\end{tabular}


Table 56. Same as Table 48 , but for case 10

\begin{tabular}{|r|c|c|c|c|}
\hline $\begin{array}{c}\mathrm{x} \\
(\mathrm{km})\end{array}$ & $\begin{array}{c}\text { Dose }(\mathrm{NS}) \\
(\text { Rem })\end{array}$ & $\begin{array}{c}\text { Dose (AS) } \\
(\text { Rem })\end{array}$ & $\begin{array}{c}\sigma_{\mathrm{y}}(\mathrm{NS}) \\
(\mathrm{m})\end{array}$ & $\begin{array}{c}\sigma_{\mathrm{z}}(\mathrm{NS}) \\
(\mathrm{m})\end{array}$ \\
\hline 2.0 & $0.372 \mathrm{E}-05$ & $0.3781 \mathrm{E}-05$ & $0.6064 \mathrm{E}+02$ & $0.6059 \mathrm{E}+02$ \\
4.0 & $0.144 \mathrm{E}-05$ & $0.1444 \mathrm{E}-05$ & $0.1182 \mathrm{E}+03$ & $0.1181 \mathrm{E}+03$ \\
6.0 & $0.691 \mathrm{E}-06$ & $0.7025 \mathrm{E}-06$ & $0.1758 \mathrm{E}+03$ & $0.1757 \mathrm{E}+03$ \\
8.0 & $0.402 \mathrm{E}-06$ & $0.4091 \mathrm{E}-06$ & $0.2334 \mathrm{E}+03$ & $0.2332 \mathrm{E}+03$ \\
10.0 & $0.262 \mathrm{E}-06$ & $0.2664 \mathrm{E}-06$ & $0.2910 \mathrm{E}+03$ & $0.2908 \mathrm{E}+03$ \\
12.0 & $0.184 \mathrm{E}-06$ & $0.1869 \mathrm{E}-06$ & $0.3486 \mathrm{E}+03$ & $0.3483 \mathrm{E}+03$ \\
14.0 & $0.139 \mathrm{E}-06$ & $0.1402 \mathrm{E}-06$ & $0.4062 \mathrm{E}+03$ & $0.4000 \mathrm{E}+03$ \\
16.0 & $0.121 \mathrm{E}-06$ & $0.1228 \mathrm{E}-06$ & $0.4638 \mathrm{E}+03$ & $0.4000 \mathrm{E}+03$ \\
18.0 & $0.108 \mathrm{E}-06$ & $0.1092 \mathrm{E}-06$ & $0.5214 \mathrm{E}+03$ & $0.4000 \mathrm{E}+03$ \\
20.0 & $0.967 \mathrm{E}-07$ & $0.9836 \mathrm{E}-07$ & $0.5790 \mathrm{E}+03$ & $0.4000 \mathrm{E}+03$ \\
22.0 & $0.878 \mathrm{E}-07$ & $0.8946 \mathrm{E}-07$ & $0.6366 \mathrm{E}+03$ & $0.4000 \mathrm{E}+03$ \\
24.0 & $0.805 \mathrm{E}-07$ & $0.8203 \mathrm{E}-07$ & $0.6942 \mathrm{E}+03$ & $0.4000 \mathrm{E}+03$ \\
26.0 & $0.744 \mathrm{E}-07$ & $0.7575 \mathrm{E}-07$ & $0.7518 \mathrm{E}+03$ & $0.4000 \mathrm{E}+03$ \\
28.0 & $0.692 \mathrm{E}-07$ & $0.7036 \mathrm{E}-07$ & $0.8094 \mathrm{E}+03$ & $0.4000 \mathrm{E}+03$ \\
30.0 & $0.647 \mathrm{E}-07$ & $0.6569 \mathrm{E}-07$ & $0.8670 \mathrm{E}+03$ & $0.4000 \mathrm{E}+03$ \\
\hline \multicolumn{5}{|c|}{}
\end{tabular}

Table 57. Same as Table 48, but for case 11

\begin{tabular}{|c|c|c|c|c|}
\hline $\begin{array}{c}\mathrm{x} \\
(\mathrm{km})\end{array}$ & $\begin{array}{c}\text { Dose (NS) } \\
(\text { Rem })\end{array}$ & $\begin{array}{c}\text { Dose (AS) } \\
(\text { Rem })\end{array}$ & $\begin{array}{c}\sigma_{\mathrm{y}}(\mathrm{NS}) \\
(\mathrm{m})\end{array}$ & $\begin{array}{c}\sigma_{\mathrm{z}}(\mathrm{NS}) \\
(\mathrm{m})\end{array}$ \\
\hline 2.0 & $0.185 \mathrm{E}-04$ & $0.1097 \mathrm{E}-05$ & $0.2225 \mathrm{E}+02$ & $0.2227 \mathrm{E}+02$ \\
4.0 & $0.350 \mathrm{E}-05$ & $0.4553 \mathrm{E}-05$ & $0.4145 \mathrm{E}+02$ & $0.4148 \mathrm{E}+02$ \\
6.0 & $0.408 \mathrm{E}-05$ & $0.3781 \mathrm{E}-05$ & $0.6064 \mathrm{E}+02$ & $0.6070 \mathrm{E}+02$ \\
8.0 & $0.268 \mathrm{E}-05$ & $0.2700 \mathrm{E}-05$ & $0.7984 \mathrm{E}+02$ & $0.7992 \mathrm{E}+02$ \\
10.0 & $0.194 \mathrm{E}-05$ & $0.1943 \mathrm{E}-05$ & $0.9904 \mathrm{E}+02$ & $0.9914 \mathrm{E}+02$ \\
12.0 & $0.144 \mathrm{E}-05$ & $0.1442 \mathrm{E}-05$ & $0.1182 \mathrm{E}+03$ & $0.1184 \mathrm{E}+03$ \\
14.0 & $0.110 \mathrm{E}-05$ & $0.1105 \mathrm{E}-05$ & $0.1374 \mathrm{E}+03$ & $0.1376 \mathrm{E}+03$ \\
16.0 & $0.865 \mathrm{E}-06$ & $0.8701 \mathrm{E}-06$ & $0.1566 \mathrm{E}+03$ & $0.1568 \mathrm{E}+03$ \\
18.0 & $0.697 \mathrm{E}-06$ & $0.7013 \mathrm{E}-06$ & $0.1758 \mathrm{E}+03$ & $0.1760 \mathrm{E}+03$ \\
20.0 & $0.573 \mathrm{E}-06$ & $0.5765 \mathrm{E}-06$ & $0.1950 \mathrm{E}+03$ & $0.1952 \mathrm{E}+03$ \\
22.0 & $0.479 \mathrm{E}-06$ & $0.4818 \mathrm{E}-06$ & $0.2142 \mathrm{E}+03$ & $0.2144 \mathrm{E}+03$ \\
24.0 & $0.406 \mathrm{E}-06$ & $0.4084 \mathrm{E}-06$ & $0.2334 \mathrm{E}+03$ & $0.2337 \mathrm{E}+03$ \\
26.0 & $0.348 \mathrm{E}-06$ & $0.3504 \mathrm{E}-06$ & $0.2526 \mathrm{E}+03$ & $0.2529 \mathrm{E}+03$ \\
28.0 & $0.302 \mathrm{E}-06$ & $0.3039 \mathrm{E}-06$ & $0.2718 \mathrm{E}+03$ & $0.2721 \mathrm{E}+03$ \\
30.0 & $0.264 \mathrm{E}-06$ & $0.2659 \mathrm{E}-06$ & $0.2910 \mathrm{E}+03$ & $0.2913 \mathrm{E}+03$ \\
\hline
\end{tabular}


Table 58. Same as Table 48, but for case 12

\begin{tabular}{|r|c|c|c|c|}
\hline $\begin{array}{c}\mathbf{x} \\
(\mathrm{km})\end{array}$ & $\begin{array}{c}\text { Dose (NS) } \\
(\text { Rem })\end{array}$ & $\begin{array}{c}\text { Dose }(\mathrm{AS}) \\
(\text { Rem })\end{array}$ & $\begin{array}{c}\sigma_{\mathrm{y}}(\mathrm{NS}) \\
(\mathrm{m})\end{array}$ & $\begin{array}{c}\sigma_{\mathrm{z}}(\mathrm{NS}) \\
(\mathrm{m})\end{array}$ \\
\hline 2.0 & $0.142 \mathrm{E}-04$ & $0.1458 \mathrm{E}-04$ & $0.9904 \mathrm{E}+02$ & $0.9903 \mathrm{E}+02$ \\
4.0 & $0.422 \mathrm{E}-05$ & $0.4328 \mathrm{E}-05$ & $0.1950 \mathrm{E}+03$ & $0.1950 \mathrm{E}+03$ \\
6.0 & $0.195 \mathrm{E}-05$ & $0.1997 \mathrm{E}-05$ & $0.2910 \mathrm{E}+03$ & $0.2910 \mathrm{E}+03$ \\
8.0 & $0.112 \mathrm{E}-05$ & $0.1140 \mathrm{E}-05$ & $0.3870 \mathrm{E}+03$ & $0.3870 \mathrm{E}+03$ \\
10.0 & $0.861 \mathrm{E}-06$ & $0.8843 \mathrm{E}-06$ & $0.4830 \mathrm{E}+03$ & $0.4000 \mathrm{E}+03$ \\
12.0 & $0.719 \mathrm{E}-06$ & $0.7377 \mathrm{E}-06$ & $0.5790 \mathrm{E}+03$ & $0.4000 \mathrm{E}+03$ \\
14.0 & $0.618 \mathrm{E}-06$ & $0.6327 \mathrm{E}-06$ & $0.6750 \mathrm{E}+03$ & $0.4000 \mathrm{E}+03$ \\
16.0 & $0.539 \mathrm{E}-06$ & $0.5540 \mathrm{E}-06$ & $0.7710 \mathrm{E}+03$ & $0.4000 \mathrm{E}+03$ \\
18.0 & $0.480 \mathrm{E}-06$ & $0.4926 \mathrm{E}-06$ & $0.8670 \mathrm{E}+03$ & $0.4000 \mathrm{E}+03$ \\
20.0 & $0.432 \mathrm{E}-06$ & $0.4435 \mathrm{E}-06$ & $0.9630 \mathrm{E}+03$ & $0.4000 \mathrm{E}+03$ \\
22.0 & $0.393 \mathrm{E}-06$ & $0.4033 \mathrm{E}-06$ & $0.1059 \mathrm{E}+04$ & $0.4000 \mathrm{E}+03$ \\
24.0 & $0.360 \mathrm{E}-06$ & $0.3698 \mathrm{E}-06$ & $0.1155 \mathrm{E}+04$ & $0.4000 \mathrm{E}+03$ \\
26.0 & $0.332 \mathrm{E}-06$ & $0.3414 \mathrm{E}-06$ & $0.1251 \mathrm{E}+04$ & $0.4000 \mathrm{E}+03$ \\
28.0 & $0.309 \mathrm{E}-06$ & $0.3171 \mathrm{E}-06$ & $0.1347 \mathrm{E}+04$ & $0.4000 \mathrm{E}+03$ \\
30.0 & $0.288 \mathrm{E}-06$ & $0.2960 \mathrm{E}-06$ & $0.1443 \mathrm{E}+04$ & $0.4000 \mathrm{E}+03$ \\
\hline
\end{tabular}

Table 59. Same as Table 48, but for case 13

\begin{tabular}{|r|c|c|c|c|}
\hline $\begin{array}{c}\mathrm{x} \\
(\mathrm{km})\end{array}$ & $\begin{array}{c}\text { Dose }(\mathrm{NS}) \\
(\text { Rem })\end{array}$ & $\begin{array}{c}\text { Dose }(\mathrm{AS}) \\
(\text { Rem })\end{array}$ & $\begin{array}{c}\sigma_{\mathrm{y}}(\mathrm{NS}) \\
(\mathrm{m})\end{array}$ & $\begin{array}{c}\sigma_{\mathrm{z}}(\mathrm{NS}) \\
(\mathrm{m})\end{array}$ \\
\hline 2.0 & $0.473 \mathrm{E}-05$ & $0.4860 \mathrm{E}-05$ & $0.9904 \mathrm{E}+02$ & $0.9903 \mathrm{E}+02$ \\
4.0 & $0.140 \mathrm{E}-05$ & $0.1443 \mathrm{E}-05$ & $0.1950 \mathrm{E}+03$ & $0.1950 \mathrm{E}+03$ \\
6.0 & $0.649 \mathrm{E}-06$ & $0.6656 \mathrm{E}-06$ & $0.2910 \mathrm{E}+03$ & $0.2910 \mathrm{E}+03$ \\
8.0 & $0.373 \mathrm{E}-06$ & $0.3800 \mathrm{E}-06$ & $0.3870 \mathrm{E}+03$ & $0.3870 \mathrm{E}+03$ \\
10.0 & $0.287 \mathrm{E}-06$ & $0.2948 \mathrm{E}-06$ & $0.4830 \mathrm{E}+03$ & $0.4000 \mathrm{E}+03$ \\
12.0 & $0.240 \mathrm{E}-06$ & $0.2459 \mathrm{E}-06$ & $0.5790 \mathrm{E}+03$ & $0.4000 \mathrm{E}+03$ \\
14.0 & $0.206 \mathrm{E}-06$ & $0.2109 \mathrm{E}-06$ & $0.6750 \mathrm{E}+03$ & $0.4000 \mathrm{E}+03$ \\
16.0 & $0.180 \mathrm{E}-06$ & $0.1847 \mathrm{E}-06$ & $0.7710 \mathrm{E}+03$ & $0.4000 \mathrm{E}+03$ \\
18.0 & $0.160 \mathrm{E}-06$ & $0.1642 \mathrm{E}-06$ & $0.8670 \mathrm{E}+03$ & $0.4000 \mathrm{E}+03$ \\
20.0 & $0.144 \mathrm{E}-06$ & $0.1478 \mathrm{E}-06$ & $0.9630 \mathrm{E}+03$ & $0.4000 \mathrm{E}+03$ \\
22.0 & $0.131 \mathrm{E}-06$ & $0.1344 \mathrm{E}-\mathrm{C} C$ & $0.1059 \mathrm{E}+04$ & $0.4000 \mathrm{E}+03$ \\
24.0 & $0.120 \mathrm{E}-06$ & $0.1233 \mathrm{E}-06$ & $0.1155 \mathrm{E}+04$ & $0.4000 \mathrm{E}+03$ \\
26.0 & $0.111 \mathrm{E}-06$ & $0.1138 \mathrm{E}-06$ & $0.1251 \mathrm{E}+04$ & $0.4000 \mathrm{E}+03$ \\
28.0 & $0.103 \mathrm{E}-06$ & $0.1057 \mathrm{E}-06$ & $0.1347 \mathrm{E}+04$ & $0.4000 \mathrm{E}+03$ \\
30.0 & $0.960 \mathrm{E}-07$ & $0.9867 \mathrm{E}-07$ & $0.1443 \mathrm{E}+04$ & $0.4000 \mathrm{E}+03$ \\
\hline
\end{tabular}


Table 60. Same as Table 48 , but for case 14

\begin{tabular}{|r|c|c|c|c|}
\hline $\begin{array}{c}\mathrm{x} \\
(\mathrm{km})\end{array}$ & $\begin{array}{c}\text { Dose }(\mathrm{NS}) \\
(\text { Rem })\end{array}$ & $\begin{array}{c}\text { Dose }(\mathrm{AS}) \\
(\text { Rem })\end{array}$ & $\begin{array}{c}\sigma_{\mathrm{y}}(\mathrm{NS}) \\
(\mathrm{m})\end{array}$ & $\begin{array}{c}\sigma_{\mathrm{z}}(\mathrm{NS}) \\
(\mathrm{m})\end{array}$ \\
\hline 2.0 & $0.290 \mathrm{E}-05$ & $0.2916 \mathrm{E}-05$ & $0.9904 \mathrm{E}+02$ & $0.9903 \mathrm{E}+02$ \\
4.0 & $0.844 \mathrm{E}-06$ & $0.8656 \mathrm{E}-06$ & $0.1950 \mathrm{E}+03$ & $0.1950 \mathrm{E}+03$ \\
6.0 & $0.388 \mathrm{E}-06$ & $0.3993 \mathrm{E}-06$ & $0.2910 \mathrm{E}+03$ & $0.2910 \mathrm{E}+03$ \\
8.0 & $0.224 \mathrm{E}-06$ & $0.2280 \mathrm{E}-06$ & $0.3870 \mathrm{E}+03$ & $0.3870 \mathrm{E}+03$ \\
10.0 & $0.173 \mathrm{E}-06$ & $0.1769 \mathrm{E}-06$ & $0.4830 \mathrm{E}+03$ & $0.4000 \mathrm{E}+03$ \\
12.0 & $0.144 \mathrm{E}-06$ & $0.1475 \mathrm{E}-06$ & $0.5790 \mathrm{E}+03$ & $0.4000 \mathrm{E}+03$ \\
14.0 & $0.123 \mathrm{E}-06$ & $0.1266 \mathrm{E}-06$ & $0.6750 \mathrm{E}+03$ & $0.4000 \mathrm{E}+03$ \\
16.0 & $0.108 \mathrm{E}-06$ & $0.1108 \mathrm{E}-06$ & $0.7710 \mathrm{E}+03$ & $0.4000 \mathrm{E}+03$ \\
18.0 & $0.960 \mathrm{E}-07$ & $0.9853 \mathrm{E}-07$ & $0.8670 \mathrm{E}+03$ & $0.4000 \mathrm{E}+03$ \\
20.0 & $0.864 \mathrm{E}-07$ & $0.8871 \mathrm{E}-07$ & $0.9630 \mathrm{E}+03$ & $0.4000 \mathrm{E}+03$ \\
22.0 & $0.786 \mathrm{E}-07$ & $0.8067 \mathrm{E}-07$ & $0.1059 \mathrm{E}+04$ & $0.4000 \mathrm{E}+03$ \\
24.0 & $0.72: \mathrm{E}-07$ & $0.7396 \mathrm{E}-07$ & $0.1155 \mathrm{E}+04$ & $0.4000 \mathrm{E}+03$ \\
26.0 & $0.665 \mathrm{E}-07$ & $0.6829 \mathrm{E}-07$ & $0.1251 \mathrm{E}+04$ & $0.4000 \mathrm{E}+03$ \\
28.0 & $0.617 \mathrm{E}-07$ & $0.6342 \mathrm{E}-07$ & $0.1347 \mathrm{E}+04$ & $0.4000 \mathrm{E}+03$ \\
30.0 & $0.577 \mathrm{E}-07$ & $0.5920 \mathrm{E}-07$ & $0.1443 \mathrm{E}+04$ & $0.4000 \mathrm{E}+03$ \\
\hline
\end{tabular}

Table 61. Same as Table 48 , but for case 15

\begin{tabular}{|c|c|c|c|c|}
\hline $\begin{array}{c}\mathbf{x} \\
(\mathrm{km})\end{array}$ & $\begin{array}{c}\text { Dose (NS) } \\
(\mathrm{Rem})\end{array}$ & $\begin{array}{c}\text { Dose (AS) } \\
(\mathrm{Rem})\end{array}$ & $\begin{array}{c}\sigma_{\mathrm{y}}(\mathrm{NS}) \\
(\mathrm{m})\end{array}$ & $\begin{array}{c}\sigma_{\mathrm{z}}(\mathrm{NS}) \\
(\mathrm{m})\end{array}$ \\
\hline
\end{tabular}

\begin{tabular}{|r|c|c|c|c|}
\hline 2.0 & $0.147 \mathrm{E}-05$ & $0.1458 \mathrm{E}-05$ & $0.9904 \mathrm{E}+02$ & $0.9903 \mathrm{E}+02$ \\
4.0 & $0.431 \mathrm{E}-56$ & $0.4328 \mathrm{E}-06$ & $0.1950 \mathrm{E}+03$ & $0.1950 \mathrm{E}+03$ \\
6.0 & $0.195 \mathrm{E}-06$ & $0.1997 \mathrm{E}-06$ & $0.2910 \mathrm{E}+03$ & $0.2910 \mathrm{E}+03$ \\
8.0 & $0.112 \mathrm{E}-06$ & $0.1140 \mathrm{E}-06$ & $0.3870 \mathrm{E}+03$ & $0.3870 \mathrm{E}+03$ \\
10.0 & $0.862 \mathrm{E}-07$ & $0.8843 \mathrm{E}-07$ & $0.4830 \mathrm{E}+03$ & $0.4000 \mathrm{E}+03$ \\
12.0 & $0.719 \mathrm{E}-07$ & $0.7377 \mathrm{E}-07$ & $0.5790 \mathrm{E}+03$ & $0.4000 \mathrm{E}+03$ \\
14.0 & $0.616 \mathrm{E}-07$ & $0.6328 \mathrm{E}-07$ & $0.6750 \mathrm{E}+03$ & $0.4000 \mathrm{E}+03$ \\
16.0 & $0.540 \mathrm{E}-07$ & $0.5540 \mathrm{E}-07$ & $0.7710 \mathrm{E}+03$ & $0.4000 \mathrm{E}+03$ \\
18.0 & $0.481 \mathrm{E}-07$ & $0.4926 \mathrm{E}-07$ & $0.8670 \mathrm{E}+03$ & $0.4000 \mathrm{E}+03$ \\
20.0 & $0.432 \mathrm{E}-07$ & $0.4435 \mathrm{E}-07$ & $0.9630 \mathrm{E}+03$ & $0.4000 \mathrm{E}+03$ \\
22.0 & $0.393 \mathrm{E}-07$ & $0.4033 \mathrm{E}-07$ & $0.1059 \mathrm{E}+04$ & $0.4000 \mathrm{E}+03$ \\
24.0 & $0.360 \mathrm{E}-07$ & $0.3698 \mathrm{E}-07$ & $0.1155 \mathrm{E}+04$ & $0.4000 \mathrm{E}+03$ \\
26.0 & $0.332 \mathrm{E}-07$ & $0.3414 \mathrm{E}-07$ & $0.1251 \mathrm{E}+04$ & $0.4000 \mathrm{E}+03$ \\
28.0 & $0.309 \mathrm{E}-07$ & $0.3171 \mathrm{E}-07$ & $0.1347 \mathrm{E}+04$ & $0.4000 \mathrm{E}+03$ \\
30.0 & $0.288 \mathrm{E}-07$ & $0.2960 \mathrm{E}-07$ & $0.1443 \mathrm{E}+04$ & $0.4000 \mathrm{E}+03$ \\
\hline
\end{tabular}



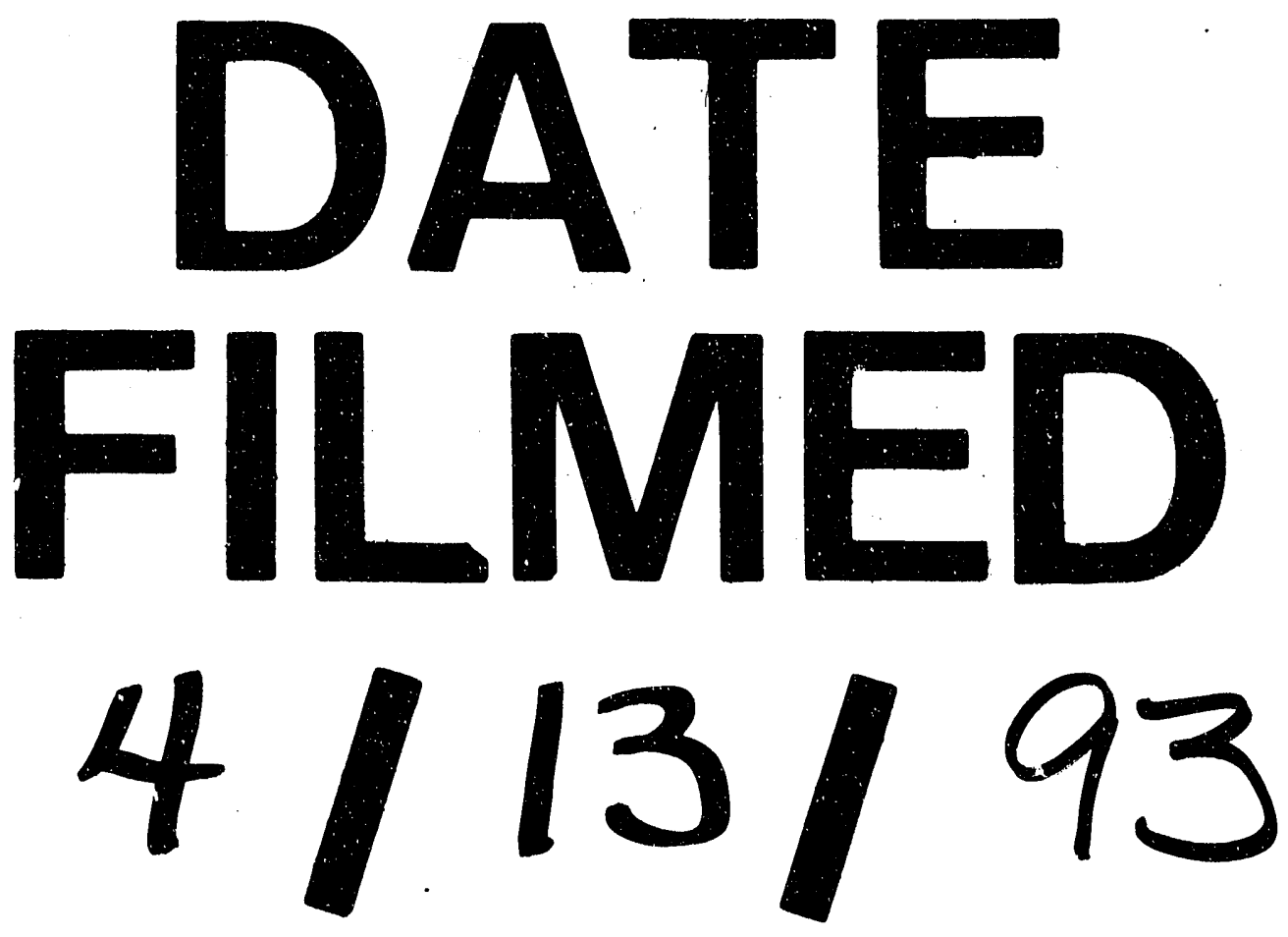
